\title{
Recombinant factor VIla for the prevention and treatment of bleeding in patients without haemophilia (Review)
}

\author{
Simpson E, Lin Y, Stanworth S, Birchall J, Doree C, Hyde C
}

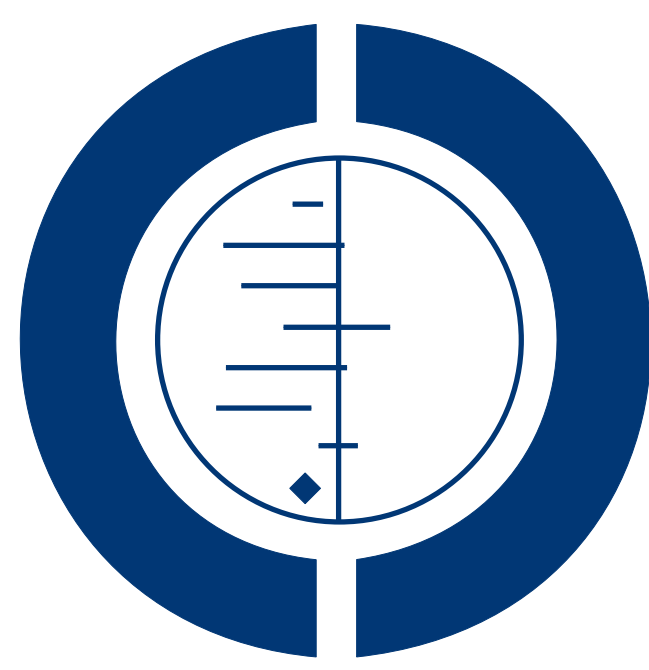

\section{THE COCHRANE COLLABORATION $^{\circledR}$}

This is a reprint of a Cochrane review, prepared and maintained by The Cochrane Collaboration and published in The Cochrane Library 2012, Issue 4

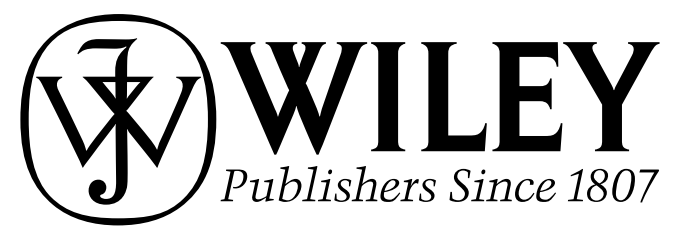

Recombinant factor VIla for the prevention and treatment of bleeding in patients without haemophilia (Review) Copyright $\odot 2012$ The Cochrane Collaboration. Published by John Wiley \& Sons, Ltd. 
TABLE OF CONTENTS

HEADER . . . . . . . . . . . . . . . . . . . . . . . . . . . . . . . . . . . . . . . . . . . . .

ABSTRACT . . . . . . . . . . . . . . . . . . . . . . . . . . . . . . . . . . . . . . . . . . . . . . 1

PLAIN LANGUAGE SUMMARY . . . . . . . . . . . . . . . . . . . . . . . . . . . . . . . . . . . . . . . . . . . . .

SUMMARY OF FINDINGS FOR THE MAIN COMPARISON ．．．．．．．． . . . . . . . . . . . . . . . 2

BACKGROUND . . . . . . . . . . . . . . . . . . . . . . . . . . . . . . . . . . . . . . . . . . . . . . .

OBJECTIVES . . . . . . . . . . . . . . . . . . . . . . . . . . . . . . . . . . . . . . . . . . . . . .

METHODS . . . . . . . . . . . . . . . . . . . . . . . . . . . . . . . . . . . . . . . .

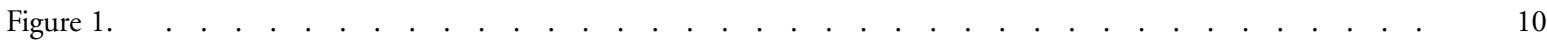

RESULTS . . . . . . . . . . . . . . . . . . . . . . . . . . . . . . . . . . . . . . . 11

Figure 2. . . . . . . . . . . . . . . . . . . . . . . . . . . . . . . . . . . . . . 13

Figure 3. . . . . . . . . . . . . . . . . . . . . . . . . . . . . . . . . . . . . . 14

Figure $4 . \quad$. . . . . . . . . . . . . . . . . . . . . . . . . . . . . . . . . . . . . . . . . 16

Figure 5. . . . . . . . . . . . . . . . . . . . . . . . . . . . . . . . . . . . . 17

Figure 6. . . . . . . . . . . . . . . . . . . . . . . . . . . . . . . . . . . . . . 18

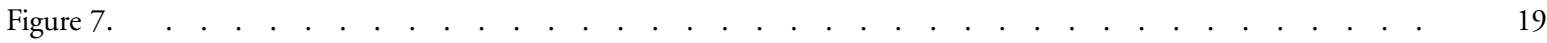

Figure 8. . . . . . . . . . . . . . . . . . . . . . . . . . . . . . . . . . . . . . 20

Figure 9. . . . . . . . . . . . . . . . . . . . . . . . . . . . . . . . . . . . . . 21

Figure 10. . . . . . . . . . . . . . . . . . . . . . . . . . . . . . . . . . . . . 22

DISCUSSION . . . . . . . . . . . . . . . . . . . . . . . . . . . . . . . . . . . . . . . . . . . . . .

AUTHORS' CONCLUSIONS . . . . . . . . . . . . . . . . . . . . . . . . . . . . . . . . . 25

REFERENCES . . . . . . . . . . . . . . . . . . . . . . . . . . . . . . . . . . . . . . . . . . . .

CHARACTERISTICS OF STUDIES . . . . . . . . . . . . . . . . . . . . . . . . . . . . . . . . . .

DATA AND ANALYSES . . . . . . . . . . . . . . . . . . . . . . . . . . . . . . . . . . . . . . . . . . . . . .

Analysis 1.1. Comparison $1 \mathrm{rFVII}$ used prophylactically versus placebo, Outcome 1 Death. . . . . . . . . . . 79

Analysis 1.2. Comparison $1 \mathrm{rFVII}$ a used prophylactically versus placebo, Outcome 2 Death - exploring heterogeneity. 81

Analysis 1.3. Comparison $1 \mathrm{rFVIIa}$ used prophylactically versus placebo, Outcome 3 Total operative and perioperative blood loss $(\mathrm{mL})$.

Analysis 1.4. Comparison $1 \mathrm{rFVIIa}$ used prophylactically versus placebo, Outcome 4 Total operative and perioperative blood loss $(\mathrm{mL})$ - exploring heterogeneity.

Analysis 1.5. Comparison $1 \mathrm{rFVIIa}$ used prophylactically versus placebo, Outcome 5 Red cell transfusion requirements $(\mathrm{mL})$.

Analysis 1.6. Comparison $1 \mathrm{rFVIIa}$ used prophylactically versus placebo, Outcome 6 Red cell transfusion requirements exploring heterogeneity. . . . . . . . . . . . . . . . . . . . . . . . . . . . . . . . . . .

Analysis 1.7. Comparison $1 \mathrm{rFVII}$ used prophylactically versus placebo, Outcome 7 Numbers of patients transfused.

Analysis 1.8. Comparison $1 \mathrm{rFVIIa}$ used prophylactically versus placebo, Outcome 8 Numbers of patients transfused exploring heterogeneity. . . . . . . . . . . . . . . . . . . . . . . . . . . . . . . . . . . . . . . . .

Analysis 1.9. Comparison $1 \mathrm{rFVIIa}$ used prophylactically versus placebo, Outcome 9 Total thromboembolic events. .

Analysis 1.10. Comparison $1 \mathrm{rFVII}$ used prophylactically versus placebo, Outcome 10 Total thromboembolic events exploring heterogeneity. . . . . . . . . . . . . . . . . . . . . . . . . . . . . . . . . . . . . . . . . . 93

Analysis 2.1. Comparison 2 rFVIIa used therapeutically versus placebo, Outcome 1 Death. . . . . . . . . . . . . 94

Analysis 2.2. Comparison 2 rFVIIa used therapeutically versus placebo, Outcome 2 Death - exploring heterogeneity. 95

Analysis 2.3. Comparison 2 rFVIIa used therapeutically versus placebo, Outcome 3 Control of bleeding (number of patients with reduced bleeding).

Analysis 2.4. Comparison 2 rFVIIa used therapeutically versus placebo, Outcome 4 Control of bleeding - exploring heterogeneity.

Analysis 2.5. Comparison $2 \mathrm{rFVIIa}$ used therapeutically versus placebo, Outcome 5 Red cell transfusion requirements $(\mathrm{mL})$.

Analysis 2.6. Comparison $2 \mathrm{rFVIIa}$ used therapeutically versus placebo, Outcome 6 Red cell transfusion requirements $(\mathrm{mL})$ - exploring heterogeneity. . . . . . . . . . . . . . . . . . . . . . . . . . . . . . . 100

Analysis 2.7. Comparison 2 rFVIIa used therapeutically versus placebo, Outcome 7 Number of patients transfused. . 101

Analysis 2.8. Comparison 2 rFVIIa used therapeutically versus placebo, Outcome 8 Total thromboembolic events. $\quad . \quad 102$

Recombinant factor VIla for the prevention and treatment of bleeding in patients without haemophilia (Review)

Copyright (๑) 2012 The Cochrane Collaboration. Published by John Wiley \& Sons, Ltd. 
Analysis 2.9. Comparison 2 rFVIIa used therapeutically versus placebo, Outcome 9 Total thromboembolic events exploring heterogeneity. . . . . . . . . . . . . . . . . . . . . . . . . . . . . . .

Analysis 3.1. Comparison 3 rFVIIa used prophylactically or therapeutically versus placebo (adverse events), Outcome 1 Total thromboembolic events. . . . . . . . . . . . . . . . . . . . . . . . . . . . . . . . .

Analysis 3.2. Comparison 3 rFVIIa used prophylactically or therapeutically versus placebo (adverse events), Outcome 2 Cardiovascular events, including myocardial infarction. . . . . . . . . . . . . . . . . . . . . . .

Analysis 3.3. Comparison 3 rFVIIa used prophylactically or therapeutically versus placebo (adverse events), Outcome 3 Stroke. . . . . . . . . . . . . . . . . . . . . . . . . . . . . . . . . . . . .

Analysis 3.4. Comparison 3 rFVIIa used prophylactically or therapeutically versus placebo (adverse events), Outcome 4 Total arterial events.

Analysis 3.5. Comparison 3 rFVIIa used prophylactically or therapeutically versus placebo (adverse events), Outcome 5

Total venous events. . . . . . . . . . . . . . . . . . . . . . . . . . . . . . . .

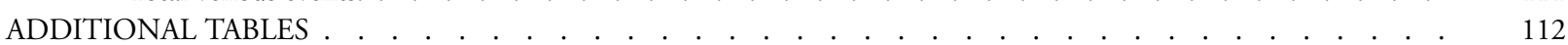

APPENDICES . . . . . . . . . . . . . . . . . . . . . . . . . . . . . . . . . . . . . 117

WHAT'S NEW . . . . . . . . . . . . . . . . . . . . . . . . . . . . . . . . . . . . . 119

HISTORY . . . . . . . . . . . . . . . . . . . . . . . . . . . . . . . . . . . . . . . 119

CONTRIBUTIONS OF AUTHORS . . . . . . . . . . . . . . . . . . . . . . . . . . . . . . . . . . . . . 119

DECLARATIONS OF INTEREST . . . . . . . . . . . . . . . . . . . . . . . . . . . . . . . . . . 120

SOURCES OF SUPPORT . . . . . . . . . . . . . . . . . . . . . . . . . . . . . . . . . . . . . . . . . . 120

INDEX TERMS . . . . . . . . . . . . . . . . . . . . . . . . . . . . . . . . . . . . . 120

Recombinant factor VIla for the prevention and treatment of bleeding in patients without haemophilia (Review) 


\title{
[Intervention Review] \\ Recombinant factor VIla for the prevention and treatment of bleeding in patients without haemophilia
}

\author{
Ewurabena Simpson ${ }^{1}$, Yulia Lin $^{2}$, Simon Stanworth ${ }^{3}$, Janet Birchall ${ }^{4}$, Carolyn Doree ${ }^{5}$, Chris Hyde $^{6}$ \\ ${ }^{1}$ Department of Paediatrics, Division of Haematology/Oncology, The Hospital for Sick Children, Toronto, Canada. ${ }^{2}$ Department of \\ Clinical Pathology, Sunnybrook Health Sciences Centre and Canadian Blood Services, Toronto, Canada. ${ }^{3}$ Haematology/Transfusion \\ Medicine, NHS Blood and Transplant, Oxford, UK. ${ }^{4}$ Haematology/Transfusion Medicine, NHS Blood and Transplant, Bristol and \\ North Bristol NHS Trust, Bristol, UK. ${ }^{5}$ Systematic Review Initiative, NHS Blood and Transplant, Oxford, UK. ${ }^{6}$ Peninsula Technology \\ Assessment Group (PenTAG), Peninsula College of Medicine \& Dentistry, Exeter, UK \\ Contact address: Simon Stanworth, Haematology/Transfusion Medicine, NHS Blood and Transplant, Level 2, John Radcliffe Hospital, \\ Headington, Oxford, OX3 9BQ, UK. simon.stanworth@nhsbt.nhs.uk.
}

Editorial group: Cochrane Injuries Group.

Publication status and date: New search for studies and content updated (no change to conclusions), published in Issue 4, 2012.

Review content assessed as up-to-date: 23 March 2011.

Citation: Simpson E, Lin Y, Stanworth S, Birchall J, Doree C, Hyde C. Recombinant factor VIIa for the prevention and treatment of bleeding in patients without haemophilia. Cochrane Database of Systematic Reviews 2012, Issue 3. Art. No.: CD005011. DOI: 10.1002/14651858.CD005011.pub4.

Copyright (C) 2012 The Cochrane Collaboration. Published by John Wiley \& Sons, Ltd.

\begin{abstract}
A B S T R A C T
Background

Recombinant factor VIIa (rFVIIa) is licensed for use in patients with haemophilia and inhibitory allo-antibodies and for prophylaxis and treatment of patients with congenital factor VII deficiency. It is also used for off-license indications to prevent bleeding in operations where blood loss is likely to be high, and/or to stop bleeding that is proving difficult to control by other means. This is the third version of the 2007 Cochrane review on the use of recombinant factor VIIa for the prevention and treatment of bleeding in patients without haemophilia, and has been updated to incorporate recent trial data.
\end{abstract}

Objectives

To assess the effectiveness of rFVIIa when used therapeutically to control active bleeding or prophylactically to prevent (excessive) bleeding in patients without haemophilia.

\section{Search methods}

We searched the Cochrane Central Register of Controlled Trials (CENTRAL), MEDLINE, EMBASE and other medical databases up to 23 March 2011.

\section{Selection criteria}

Randomised controlled trials (RCTs) comparing rFVIIa with placebo, or one dose of rFVIIa with another, in any patient population (except haemophilia). Outcomes were mortality, blood loss or control of bleeding, red cell transfusion requirements, number of patients transfused and thromboembolic adverse events.

\section{Data collection and analysis}

Two authors independently assessed potentially relevant studies for inclusion, extracted data and examined risk of bias. We considered prophylactic and therapeutic rFVIIa studies separately.

Recombinant factor VIla for the prevention and treatment of bleeding in patients without haemophilia (Review)

Copyright $\odot 2012$ The Cochrane Collaboration. Published by John Wiley \& Sons, Ltd. 


\section{Main results}

Twenty-nine RCTs were included: 28 were placebo-controlled, double-blind RCTs and one compared different doses of rFVIIa. In the 'Risk of bias' assessment, most studies were found to have some threats to validity although therapeutic RCTs were found to be less prone to bias than prophylactic RCTs.

Sixteen trials involving 1361 participants examined the prophylactic use of rFVIIa; 729 received rFVIIa. There was no evidence of mortality benefit (risk ratio (RR) 1.04; 95\% confidence interval (CI) 0.55 to 1.97). There was decreased blood loss (mean difference (MD) $-297 \mathrm{~mL}$; 95\% CI -416 to -178) and decreased red cell transfusion requirements (MD -261 mL; 95\% CI -367 to -154) with rFVIIa treatment; however, these values were likely overestimated due to the inability to incorporate data from trials (four RCTs in the outcome of blood loss and three RCTs in the outcome of transfusion requirements) showing no difference of rFVIIa treatment compared to placebo. There was a trend in favour of rFVIIa in the number of participants transfused (RR 0.85; 95\% CI 0.72 to 1.01). However, there was a trend against rFVIIa with respect to thromboembolic adverse events (RR 1.35; 95\% CI 0.82 to 2.25 ).

Thirteen trials involving 2929 participants examined the therapeutic use of rFVIIa; 1878 received rFVIIa. There were no outcomes where any observed advantage or disadvantage of rFVIIa over placebo could not have been observed by chance alone. There was a trend in favour of rFVIIa for reducing mortality (RR 0.91 ; $95 \%$ CI 0.78 to 1.06). However, there was a trend against rFVIIa for increased thromboembolic adverse events (RR 1.14; $95 \%$ CI 0.89 to 1.47 ).

When all trials were pooled together to examine the risk of thromboembolic events, a significant increase in total arterial events was observed (RR 1.45 ; $95 \%$ CI 1.02 to 2.05 ).

\section{Authors' conclusions}

The effectiveness of rFVIIa as a more general haemostatic drug, either prophylactically or therapeutically, remains unproven. The results indicate increased risk of arterial events in patients receiving rFVIIa. The use of rFVIIa outside its current licensed indications should be restricted to clinical trials.

\section{PLAIN LANGUAGESUMMARY}

\section{Recombinant factor VIIa for the prevention and treatment of bleeding in patients without haemophilia}

The purpose of this review was to evaluate the evidence of effectiveness and safety for the use of recombinant factor VIIa (rFVIIa). This drug has been used in patients who are either at risk of major bleeding (e.g. because of planned high-risk surgery), or who have uncontrolled bleeding (e.g. related to trauma). There have been many articles in the literature describing the off-license use of this drug, which often suggest benefit. However, most of the publications are based on small numbers of patients (in case reports or case series) and may be affected by bias. Randomised controlled trials provide higher-quality research findings and allow us to assess the evidence of drug effectiveness with more certainty.

This review included 29 randomised controlled trials with 4290 patients. The trials showed modest reductions in total blood loss or red cells transfused (equivalent to less than one unit of red cell transfusion) with the use of rFVIIa. However, the reductions were likely to be overestimated due to the limitations of the data. We also observed an increase in the risk of having a blood clot in the arteries (such as a heart attack or stroke) in those patients receiving rFVIIa. When taken together, the data supporting the off-license use of recombinant FVIIa are weak. The use of rFVIIa outside its current licensed indications should be restricted to clinical trials.

Recombinant factor VIla for the prevention and treatment of bleeding in patients without haemophilia (Review) 


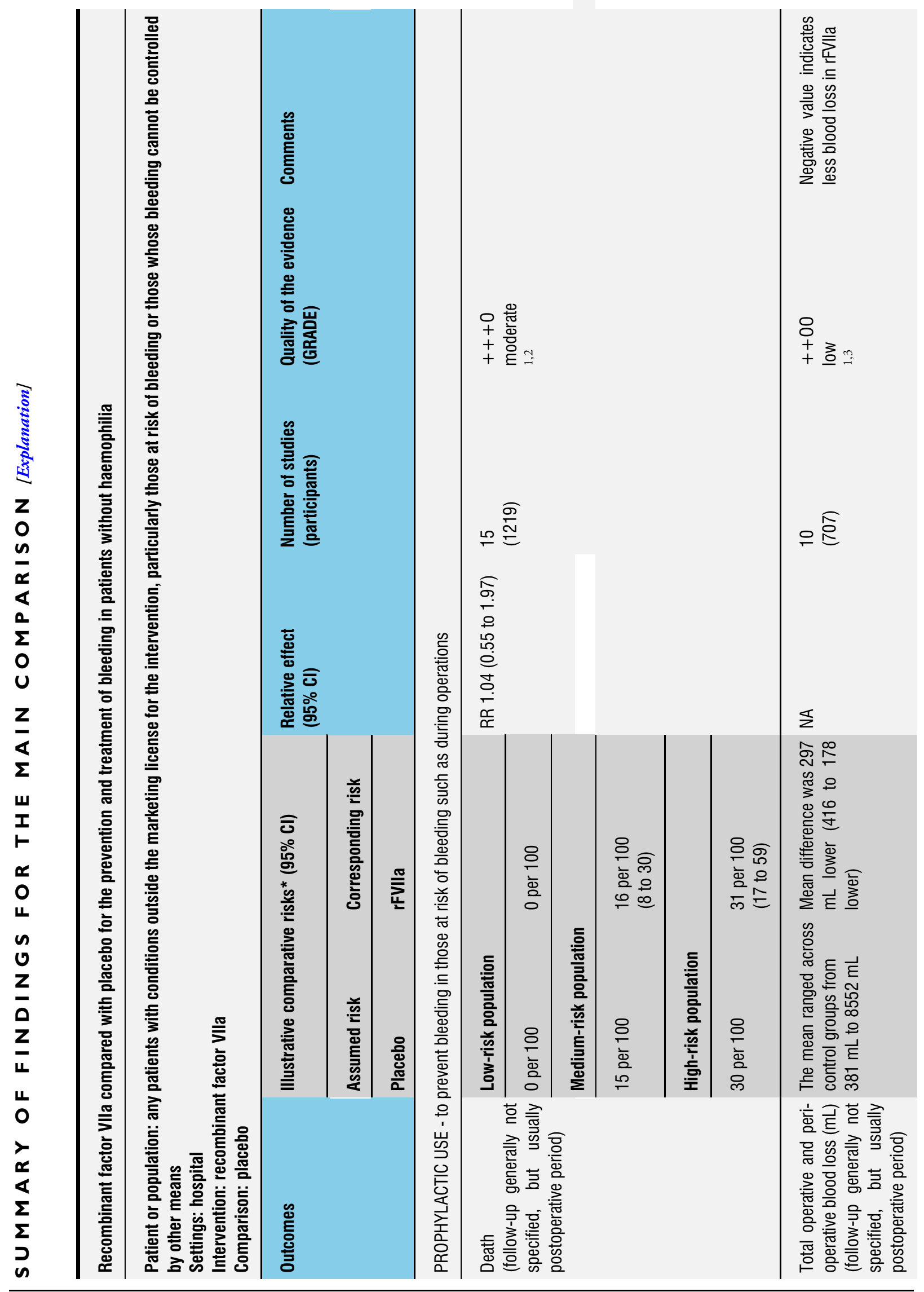

Recombinant factor VIla for the prevention and treatment of bleeding in patients without haemophilia (Review)

Copyright $\odot 2012$ The Cochrane Collaboration. Published by John Wiley \& Sons, Ltd. 


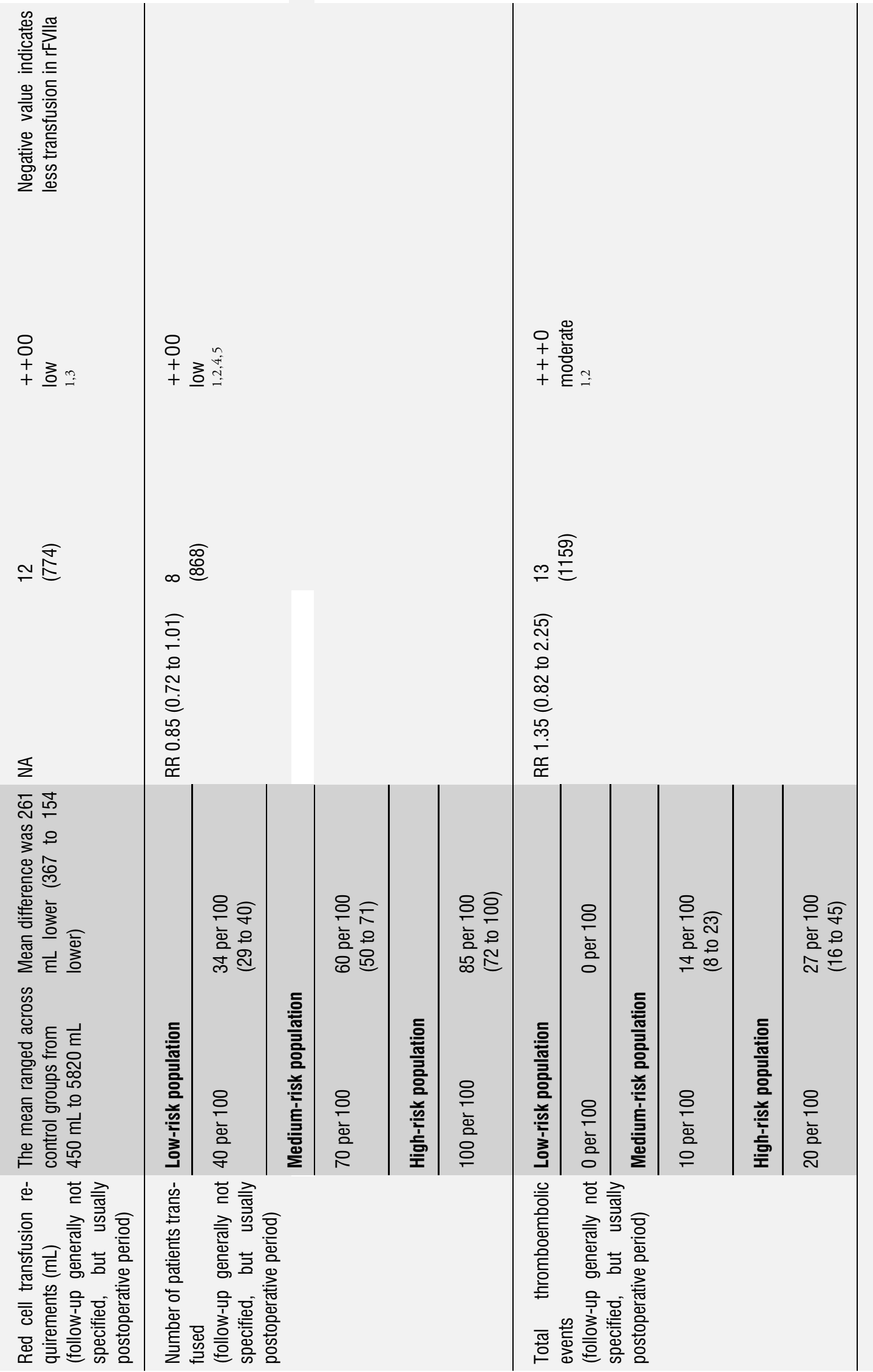

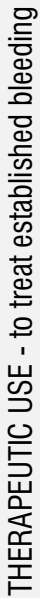

Recombinant factor VIla for the prevention and treatment of bleeding in patients without haemophilia (Review)

Copyright @ 2012 The Cochrane Collaboration. Published by John Wiley \& Sons, Ltd. 


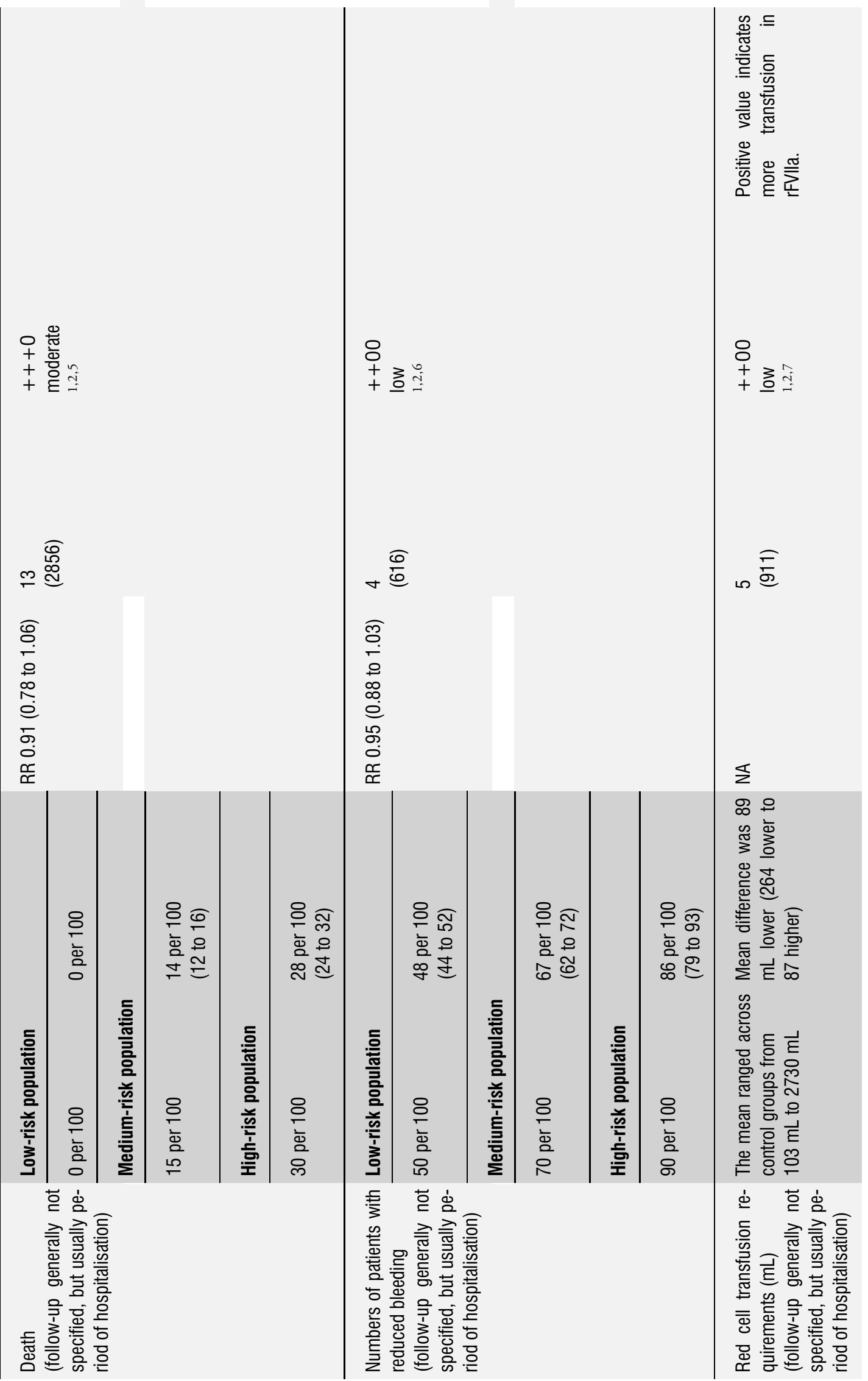

Recombinant factor VIla for the prevention and treatment of bleeding in patients without haemophilia (Review)

Copyright $\odot 2012$ The Cochrane Collaboration. Published by John Wiley \& Sons, Ltd. 


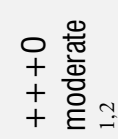

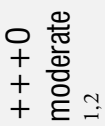

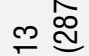

畨

న

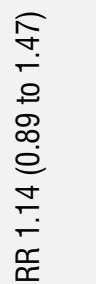

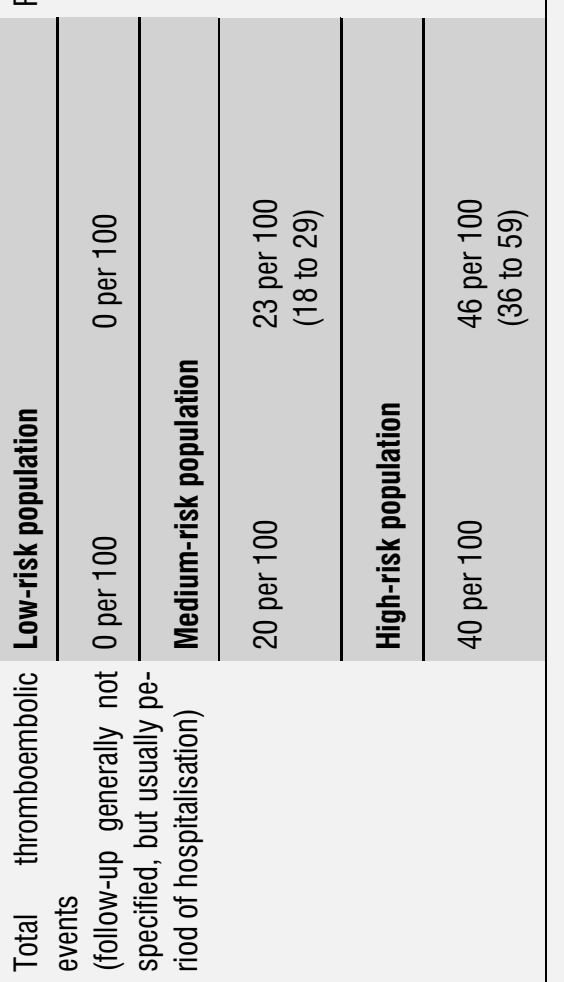

م

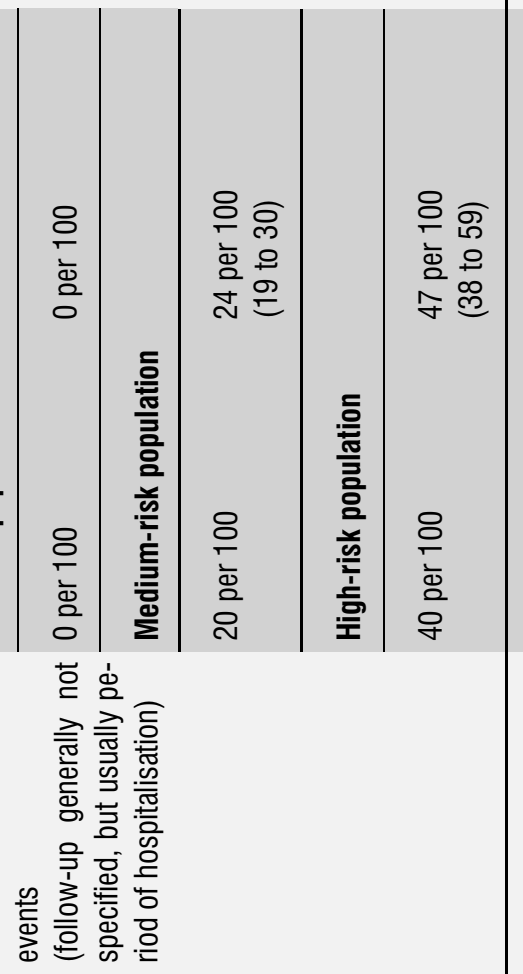

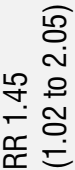

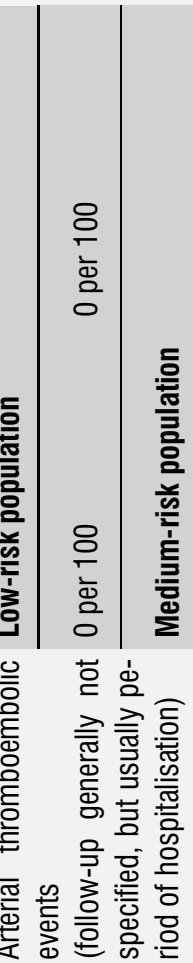




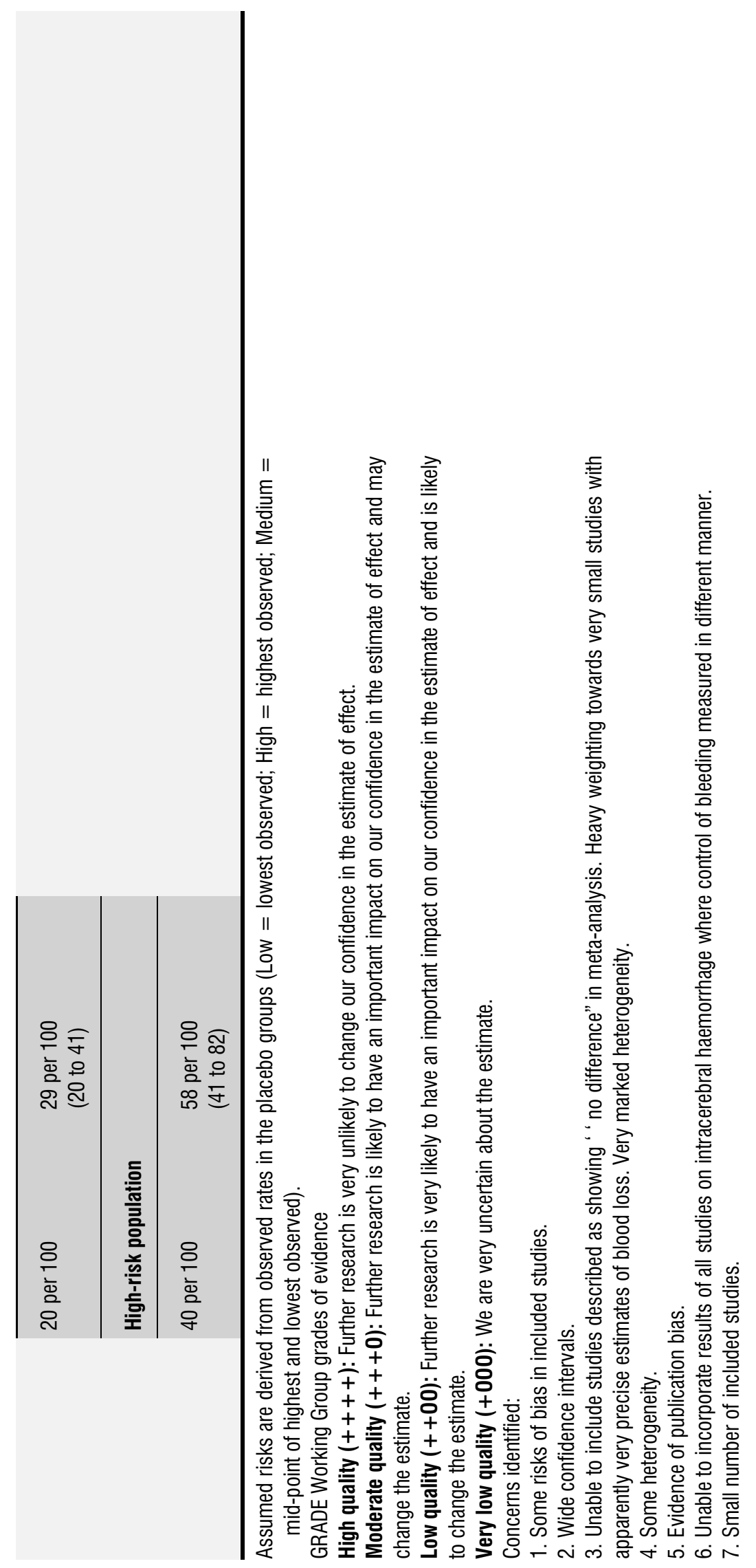

Recombinant factor VIla for the prevention and treatment of bleeding in patients without haemophilia (Review)

Copyright @ 2012 The Cochrane Collaboration. Published by John Wiley \& Sons, Ltd. 


\section{B A C K G R O U N D}

Recombinant activated factor VII (rFVIIa) (NovoSeven ${ }^{\circledR}$, Novo Nordisk, Denmark) has been manufactured and used clinically for a number of years for the treatment of bleeding in individuals with haemophilia and inhibitory antibodies to factor VIII (Lusher 1998) as well as other congenital bleeding disorders such as inherited factor VII deficiency and Glanzmann's thrombasthenia. More recently, the potential of rFVIIa to minimise or control severe bleeding in a variety of medical and surgical situations has engendered considerable interest (Hedner 2002). The hypothesis that high-dose rFVIIa would be capable of enhancing haemostasis at the local site of injury, without systemic activation of the coagulation cascade and the risk of widespread inappropriate thrombosis, would clearly be an asset for clinical use (Key 2003a).

The initial evidence on the clinical role of rFVIIa for patients without inherited defects of haemostasis was dominated by case reports and small case series (Ahonen 2005; Greisen 2003; Key 2003b). However, over the years, data from randomised controlled trials have been reported, which should provide the most robust means of evaluating drug effectiveness and safety. These trials have assessed drug use in a variety of clinical scenarios in which rFVIIa may have a role, including excessive surgical bleeding, uncontrolled medical bleeding and trauma. However, bleeding in these clinical settings has multiple causes, including diffuse small vessel oozing, dilution of clotting factors and platelets from massive transfusion, disseminated intravascular coagulation, hyperfibrinolysis, hypothermia (with slowing of the enzymatic reactions in coagulation) and acidosis, and it is unclear what effect rFVIIa would have on haemostasis in the setting of each or a combination of these factors. Many hospitals report that off-label use of rFVIIa as a general or 'universal haemostatic agent' has been increasing at least up until 2008 (Isbister 2008; Logan 2010; Logan 2011; Roberts 2004).

One of the concerns about extending the use of a coagulation factor treatment such as rFVIIa to different patient groups is the potential for adverse effects, in particular the risk of thromboembolism (Levi 2010; O’Connell 2006).

To examine the effectiveness and safety of recombinant factor VIIa with the addition of larger randomised controlled trials, we have produced this third version of the Cochrane review on the use of recombinant factor VIIa for the prevention and treatment of bleeding in patients without haemophilia, which was first published in 2007.

\section{O B J E C T I VES}

The objective of this systematic review was to assess the effects of recombinant factor VIIa (rFVIIa) when used for the prophylactic or therapeutic management of haemorrhage in patients without haemophilia.

\section{METHODS}

\section{Criteria for considering studies for this review}

\section{Types of studies}

Randomised controlled trials (RCTs).

\section{Types of participants}

Patients at risk of blood loss due to surgery, or who had received treatment to manage bleeding. We considered all age groups, but we excluded patients with haemophilia or other haemostatic defects (for example, Glanzmann's thrombasthenia, inherited factor VII deficiency).

\section{Types of interventions}

- RCTs comparing rFVIIa to prevent bleeding (for example, before or during surgery) with no rFVIIa.

- RCTs comparing rFVIIa to treat bleeding (for example, in the context of medical or surgical bleeding, or trauma) with no rFVIIa.

- RCTs comparing rFVIIa with alternative treatments for the prevention and/or treatment of haemorrhage.

- RCTs comparing different dose schedules of rFVIIa.

We documented details of co-interventions aimed at managing bleeding, including the use of additional 'haemostatic' drugs and policies for transfusion.

\section{Types of outcome measures}

- Survival at fixed, relevant time periods, with mortality evaluated by cause when possible (that is, as either haemorrhagic, an adverse effect of the intervention, or not related to intervention).

- Bleeding (within a predefined follow-up period postintervention), measured as response of bleeding (for example, prevented, stopped, decreased, increased, no change), number and/or duration of bleeding episodes, or severity of blood loss (for example, by volume, rate or bleeding score).

- Number of red cell transfusions required (whether as units transfused or episodes, in a follow-up period relevant to the bleeding episode).

- Number of patients avoiding transfusions (for prophylactic studies).

- Adverse effects of interventions (for example, thrombosis).

We identified other outcome information (for example, use of blood products other than red cells, impact on operation times and adverse events other than thromboembolic events) in study reports during the preparation of the first version of this review. 
In the future, we will explore the value of these data in a separate analysis.

\section{Search methods for identification of studies}

The searches were not restricted by language or publication status. Searches were conducted by the authors, working independently from the Cochrane Injuries Group Editorial Base.

\section{Electronic searches}

We searched the following databases on 23 March 2011.

- CENTRAL (Cochrane Central Register of Controlled Trials, The Cochrane Library 2011, Issue 1)

- MEDLINE (1948 to 23 March 2011)

- EMBASE (1980 to 23 March 2011)

- CINAHL (1982 to 23 March 2011)

- UK Blood Transfusion \& Tissue Transplantation Services (UKBTS) Systematic Review Initiative (SRI) Transfusion Evidence Library (www.transfusionevidencelibrary.com) (1980 to 23 March 2011)

- LILACS (1982 to 23 March 2011)

- KoreaMed (1997 to 23 March 2011)

- IndMed (1985 to 23 March 2011)

- PakMediNet (2001 to 23 March 2011)

- ISRCTN Register (23 March 2011)

- ClinicalTrials.gov (23 March 2011)

- EUDRACT (EU Clinical Trials Register) (23 March 2011)

- WHO ICTRP (International Clinical Trials Register

Portal) (23 March 2011)
In MEDLINE, we combined the search strategy with the Cochrane optimal RCT search filter described in Chapter 6.4.11 of the Cochrane Handbook for Systematic Reviews of Interventions (Higgins 2011). In EMBASE and CINAHL, we combined search strategies with adaptations of this RCT filter. Search strategies can be found in Appendix 1, Appendix 2, Appendix 3, Appendix 4 and Appendix 5.

\section{Searching other resources}

In addition, we checked the reference lists of the RCTs identified and of relevant reviews, including recently published systematic reviews (Hsia 2008; You 2006). We contacted the authors of known trials for information on any further trials of which they may be aware, whether published, unpublished or ongoing, or to provide additional data as required. We also carefully followed up ongoing trials identified in the first version of this review and identified new ongoing trials.

\section{Data collection and analysis}

\section{Selection of studies}

Two of the authors (ES, YL, SS or JB) screened all titles and abstracts of papers identified by the database searches for relevance. We excluded only clearly irrelevant studies at this stage; we assessed all other studies on the basis of their full text for inclusion/exclusion using the criteria indicated above. At this stage, two authors independently assessed eligibility and noted any discrepancies in their assessments. We only included trials available as full publications up to March 2011 (Figure 1). 
Figure I. Figure I. Flow diagram for selection of all randomized controlled trials for this review.
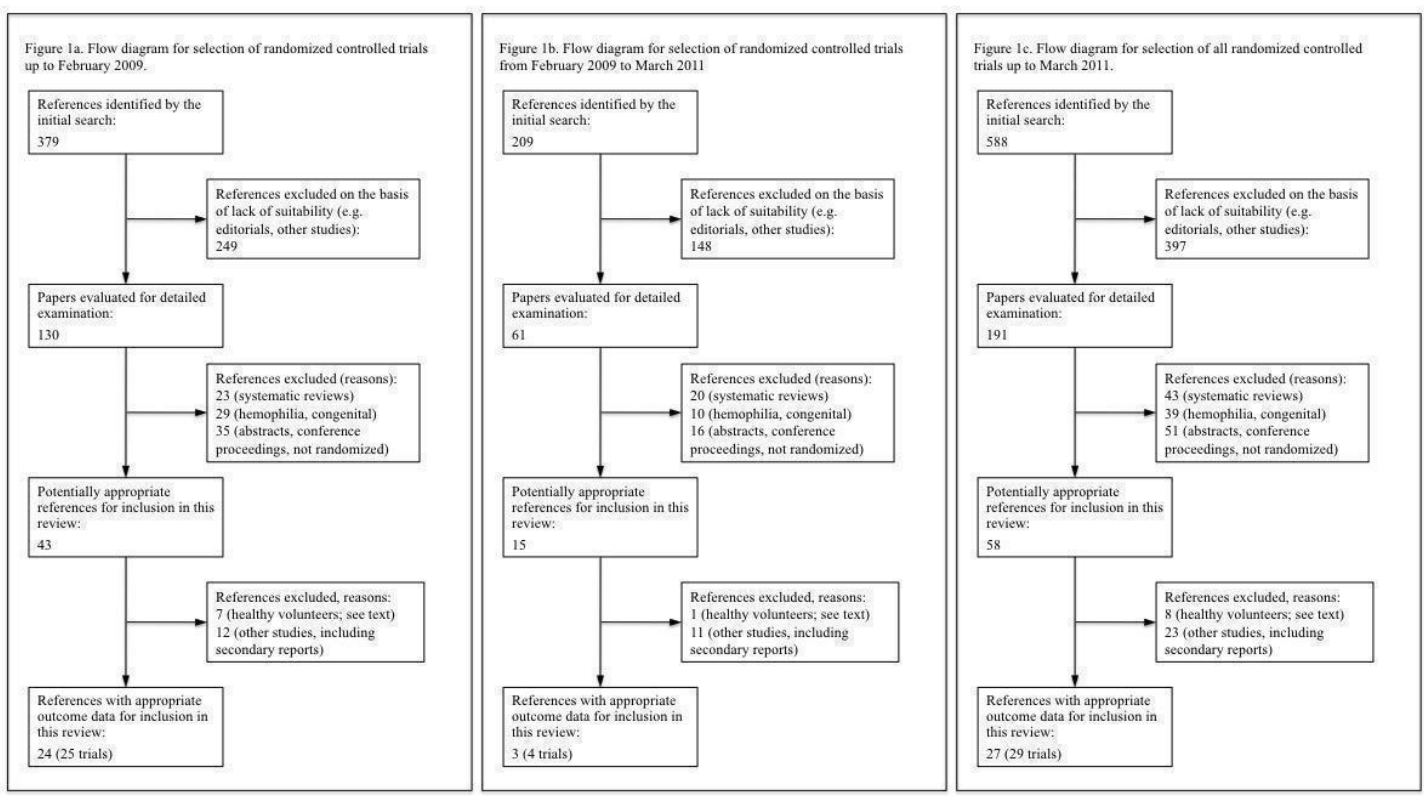

\section{Data extraction and management}

Aside from details relating to study quality, we extracted the following data.

- Study characteristics - place of publication, date of publication, population characteristics, setting, intervention, comparator and outcomes. A key purpose of these data was to examine clinical heterogeneity in the included studies independently from the analysis of results. Potential sources of clinical heterogeneity in this specific review included details of intervention (dose, frequency) and participant group (condition, clinical setting).

- Results of included studies - we extracted data for each of the main outcomes indicated in the review question. If an included study did not contribute data on a particular outcome we recorded the reason. We considered the possibility of the selective reporting of results on particular outcomes. For dichotomous outcomes, we recorded the numbers of outcomes in treatment and control groups. For continuous outcomes, we recorded means and standard deviations (SD). If median and interquartile range (IQR) were available, we used the median as the mean and converted the IQR to SD.

Two authors extracted data using data extraction forms that were purposely created and piloted for this review. The authors resolved disagreements by consensus, recording the agreed data onto a third summary data extraction form. One author transcribed this into the systematic review computer software Review Manager 5 (RevMan 2008); another author verified all data entry for discrepancies.

\section{Assessment of risk of bias in included studies}

All authors used the following criteria for judging risk of bias from the Cochrane Handbook for Systematic Reviews of Interventions version 5.0.1 (Higgins 2011) to evaluate the methodological quality of the included studies:

- generation of a random sequence;

- concealment of treatment allocation schedule;

- blinding of participants, personnel and outcome assessors;

- incomplete outcome data reporting;

- selective outcome reporting; and

- other potential threats to validity.

We rated these criteria using the 'Risk of bias' assessment tool provided in the Cochrane Handbook for Systematic Reviews of Interventions (Higgins 2011). This assigns a rating of 'Yes' (adequate), 'Unclear' and 'No' (clearly inadequate) to each specified methodological criterion. In addition, we added a criterion to the table to indicate whether a power calculation was performed for the RCT. A rating of 'Yes' was assigned if both a power calculation was performed and the target sample size was stated (regardless of whether 
or not this target was achieved), 'Unclear' if a power calculation was performed but a target sample size was not specified, and 'No' if no power calculation was performed.

We used evaluation of the methodological quality of each included study within the review in the following ways:

- either as a possible explanation for differences in results between studies or to investigate heterogeneity; or

- in sensitivity analyses, examining the effect on overall estimates of excluding studies of poor methodological quality.

\section{Measures of treatment effect}

We analysed data qualitatively and quantitatively. The preferred form of summary result was a risk ratio (RR) for binary data and mean difference (MD) for continuous data, both with $95 \%$ confidence intervals (CI). When a study reported values on continuous outcomes for subgroups of different doses of rFVIIa, we used the mean of the reported values as an overall summary effect of rFVIIa for the meta-analysis.

\section{Assessment of heterogeneity}

We examined statistical heterogeneity using the $\mathrm{Chi}^{2}$ test, the $\mathrm{I}^{2}$ statistic and visual inspection of graphs. We considered values of $\mathrm{I}^{2}$ greater than $25 \%$ to indicate a level of heterogeneity at which pooled estimates should be interpreted very cautiously and efforts focused on understanding the cause of between-study variation in results. Where the $\mathrm{I}^{2}$ was below $25 \%$ we explored the robustness of any summary measures, particularly with respect to study quality.

\section{Assessment of reporting biases}

We examined publication bias using funnel plots produced using RevMan 5 software for each of the outcome measures.

\section{Data synthesis}

We employed meta-analysis, using a fixed-effect model in the first instance, but also evaluated the results from the random-effects model. The results from the random-effects models are given in recognition of the marked clinical heterogeneity between the included studies.

\section{Subgroup analysis and investigation of heterogeneity}

One subgroup was pre-specified: rFVIIa dose. The cut-off used to distinguish low from high dose was less than $80 \mu \mathrm{g} / \mathrm{kg}$ and equal to or more than $80 \mu \mathrm{g} / \mathrm{kg}$ of rFVIIa, based on clinical opinion (and was not strictly pre-specified). No differences between the lowdose and high-dose outcomes were seen in the previous versions nor in this version, therefore these analyses are not presented.

\section{R E S U L T S}

\section{Description of studies}

See: Characteristics of included studies; Characteristics of excluded studies; Characteristics of ongoing studies.

See 'Characteristics of included studies' and 'Characteristics of ongoing studies'.

\section{Results of the search}

The updated search (conducted 23 March 2011) identified a total of 140 new records since the last version, which three authors (ES, YL, SS) reviewed independently. Figure 1 shows the study selection sequentially for each of the updates of this review.

Twenty-seven RCTs as full publications up to 23 March 2011 were eligible for inclusion. For the purposes of this review, we considered each of the studies by Boffard et al and Hauser et al as two separate trials, because they both concerned two different types of trauma: blunt (Boffard 2005a; Hauser 2010a) and penetrating (Boffard 2005b; Hauser 2010b). With these sub-populations, there was a total of 29 RCTs for analysis (see 'Characteristics of included studies').

We identified a number of potentially eligible ongoing and completed (unpublished) trials from other registers, including the meta-register of controlled trials (mRCT - includes ClinicalTrials.gov), the National Research Register, ClinicalStudyResults.org and the Novo Nordisk list of rFVIIa trials. These trials are summarised in the 'Characteristics of ongoing studies' table. An additional table (Table 1) has been included in this update summarising the status of the ongoing studies from the last version of this review (Lin 2011). Of the 11 studies in Table 1, five were completed and two were published.

\section{Included studies}

See 'Characteristics of included studies'.

\section{Prophylactic trials}

Sixteen RCTs assessed rFVIIa given prophylactically to prevent bleeding (Table 2). Nine trials were single-centre and seven were multi-centre. Eight were small with fewer than 50 patients randomised (Diprose 2005; Essam 2007; Friederich 2003; Hanna 2010; Johansson 2007; Ma 2006; Pugliese 2007; Raobaikady 2005).

\section{Participants}

The clinical setting of the included studies varied (Table 2). Five studies evaluated patients undergoing cardio-pulmonary bypass (Diprose 2005; Ekert 2006; Essam 2007; Ma 2006; Gill 2009). Six studies evaluated patients undergoing hepatic procedures: one 
in liver biopsy (Jeffers 2002), two in partial hepatectomy (Lodge 2005a; Shao 2006) and three in liver transplantation (Lodge 2005b; Planinsic 2005; Pugliese 2007). Five studies evaluated the role of rFVIIa in a variety of other conditions: paediatric craniofacial reconstruction (Hanna 2010), retropubic prostatectomy (Friederich 2003), burn patients requiring excision and grafting (Johansson 2007), pelvic fracture (Raobaikady 2005) and spinal fusion surgery (Sachs 2007). Both Sachs 2007 and Gill 2009 were considered with the prophylactic group as rFVIIa was administered at the time of a defined bleeding trigger in the perioperative setting.

All studies reported predefined exclusion criteria except Pugliese 2007. The main exclusions were evidence of pre-existing 'coagulopathy' in patients with known thromboembolic or vascular disease. In addition, Diprose 2005 and Ma 2006 excluded patients who would refuse blood products while Hanna 2010 also excluded patients with neurological disorders, and both Planinsic 2005 and Lodge 2005b excluded patients who had undergone previous transplantation.

\section{Intervention}

Fifteen of 16 trials compared rFVIIa with placebo. rFVIIa was given at a single dose in eight studies and as repeated dosing in eight studies, with three studies administering repeated dosing only if there was ongoing surgery or bleeding (Table 2). Thus there were marked differences in the doses and schedules employed. The differences are more apparent if the total dose administered is considered. This varied from $5 \mu \mathrm{g} / \mathrm{kg}$ (Jeffers 2002) to $360 \mu \mathrm{g} /$ kg (Lodge 2005b; Sachs 2007).

\section{Co-interventions}

The two main groups of important co-interventions were the use of additional 'haemostatic' drugs and transfusion (Table 2). Red cell transfusion protocols were provided in 13 studies with seven studies outlining further guidelines for platelets and/or plasma. Three studies provided no details on transfusion protocols (Ekert 2006; Jeffers 2002; Ma 2006). Co-interventions are also outlined in Table 2. Of particular interest for thromboembolic adverse events, four studies described the use of low molecular weight heparin (LMWH) in the perioperative (Raobaikady 2005) and postoperative settings (Friederich 2003; Johansson 2007; Lodge 2005a).

\section{Outcomes}

The prophylactic studies reported a variety of primary outcome measures (Table 2). However, the main outcome focus of the included studies was either blood loss (primary outcome in Friederich 2003; Raobaikady 2005; Sachs 2007), amount of blood transfused (primary outcome in Ekert 2006; Friederich 2003; Johansson 2007; Lodge 2005b; Planinsic 2005; Shao 2006), or number of patients receiving allogeneic transfusion (primary outcome in Diprose 2005; Lodge 2005a; Shao 2006). Four studies did not define a primary outcome but collected data on blood loss and transfusion requirements (Essam 2007; Hanna 2010; Ma 2006; Pugliese 2007). Finally, one study in liver biopsy (Jeffers 2002) used time to haemostasis and duration of normal prothrombin time (PT) as its primary outcomes and one study used a primary outcome of critical serious adverse events (Gill 2009).

All trials except Essam 2007 and Hanna 2010 reported adverse events including deaths and thromboembolic events. Active surveillance (planned ECG, troponin measurements or doppler ultrasound) was performed in five prophylactic studies (Friederich 2003; Lodge 2005a; Lodge 2005b; Planinsic 2005; Shao 2006). Other adverse events were reported, but the focus of this report is on death and thromboembolic events, the latter being of particular concern when using a pro-coagulant agent.

\section{Therapeutic trials}

Thirteen RCTs assessed rFVIIa given therapeutically to treat established bleeding (Table 3). All of the trials were multi-centre. Three studies were small with fewer than 50 patients randomised (Chuansumrit 2005; Mayer 2005b; Mayer 2006).

\section{Participants}

The clinical setting of the included studies varied (Table 3): four studies in severe trauma (Boffard 2005a; Boffard 2005b; Hauser 2010a; Hauser 2010b), two studies in cirrhosis with acute upper gastrointestinal bleeding (UGIB) (Bosch 2004; Bosch 2008), one study in dengue haemorrhagic fever (Chuansumrit 2005), one study in bleeding post-haematopoietic stem cell transplantation (HSCT) (Pihusch 2005), four studies in spontaneous intracranial haemorrhage (ICH) (Mayer 2005a; Mayer 2005b; Mayer 2006; Mayer 2008) and one study in traumatic ICH (Narayan 2008). All studies reported pre-defined exclusion criteria. Common exclusions related to the severity of the condition being treated (all trials) and evidence of an underlying clotting or bleeding diathesis (Bosch 2004; Bosch 2008; Mayer 2005a; Mayer 2006; Mayer 2008; Narayan 2008). In all ICH trials, patients were excluded if surgical intervention was planned within 24 hours.

\section{Intervention}

All clinical trials were placebo-controlled but the doses of rFVIIa varied widely, as did its administration (Table 3). rFVIIa was given as a single dose in the five ICH trials and as repeated dosing in the other trials, with one study administering repeated dosing only if there was ongoing bleeding (Chuansumrit 2005). The variation in doses was most evident when estimating the total dose of rFVIIa received. The minimum was 5 to $10 \mu \mathrm{g} / \mathrm{kg}$ in Mayer 2006 and Mayer 2005b, extending to $1120 \mu \mathrm{g} / \mathrm{kg}$ in Pihusch 2005, a 100fold variation. 


\section{Co-interventions}

The two main groups of important co-interventions were the use of additional 'haemostatic' drugs and transfusion (Table 3). Five studies described transfusion protocols (Bosch 2004; Bosch 2008; Hauser 2010a; Hauser 2010b; Pihusch 2005). The five ICH studies did not provide a transfusion protocol, which was appropriate as these patients are rarely transfused. The remaining three studies (Boffard 2005a; Boffard 2005b; Chuansumrit 2005) did not provide transfusion protocols. Although these studies did not include transfusion protocols, transfusion requirements were cited as the primary outcome in Boffard 2005a and Boffard 2005b.

\section{Outcomes}

The therapeutic studies reported multiple outcome measures (see Table 3 and 'Characteristics of included studies'). In the majority of the included trials (Bosch 2004; Bosch 2008; Chuansumrit 2005; Mayer 2005a; Pihusch 2005) the primary endpoint was a measure of change in bleeding. By contrast, Boffard 2005a and Boffard $2005 \mathrm{~b}$ defined the primary endpoint as transfusion requirements. The primary endpoint in Mayer 2008 was a clinical outcome as defined by the modified Rankin scale at day 90. Mayer 2005b, Mayer 2006 and Narayan 2008 defined their primary outcome as the frequency of adverse events that were (possibly or probably) treatment-related. Hauser 2010a and Hauser 2010b measured allcause 30-day mortality as the primary outcome.

Again, other secondary outcomes for all included treatment trials included adverse events, particularly deaths and thromboembolic events, which were monitored either clinically or additionally by Doppler ultrasound. Other adverse events were reported, but deaths and thromboembolic events are the focus of this review.

\section{Sources of support}

Nine of 16 prophylactic trials were either supported by Novo Nordisk, the manufacturer of rFVIIa or were co-authored by an employee of Novo Nordisk. All therapeutic trials were supported by the company or co-authored by an employee of Novo Nordisk. Details are provided in the 'Characteristics of included studies'.

\section{Risk of bias in included studies}

Full details of quality assessments are presented in the 'Risk of bias' table presented with each study in the 'Characteristics of included studies' table. Figure 2 and Figure 3 give visual representations of the assessments of risk of bias across all studies and for each item in the individual studies, respectively.

Figure 2. Methodological quality graph: review authors' judgements about each methodological quality item presented as percentages across all included studies.

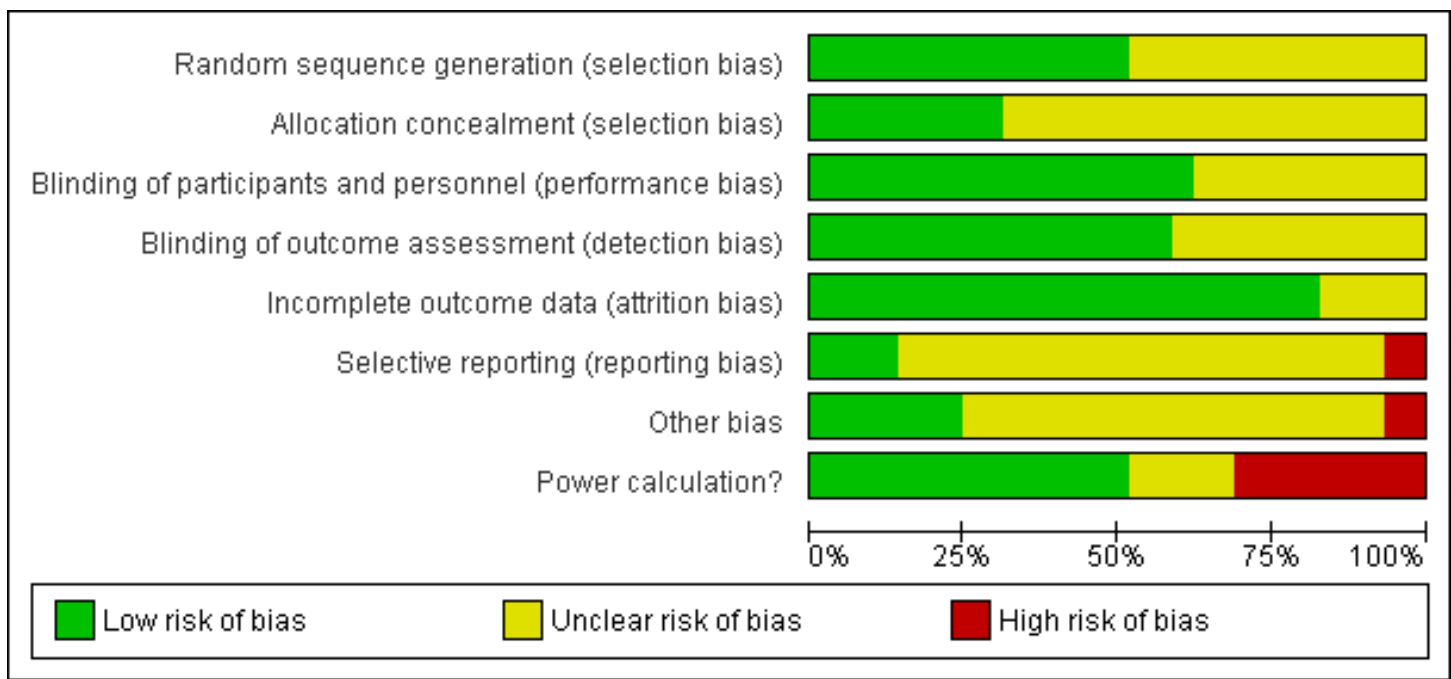

Recombinant factor VIla for the prevention and treatment of bleeding in patients without haemophilia (Review) 
Figure 3. Methodological quality summary: review authors' judgements about each methodological quality item for each included study.

\begin{tabular}{|c|c|c|c|c|c|c|c|c|}
\hline & 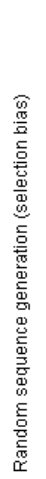 & 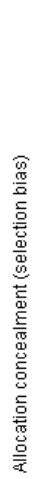 & 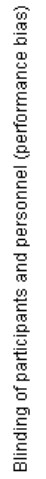 & 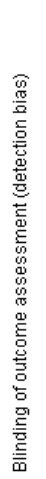 & 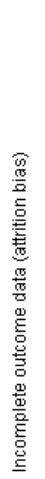 & 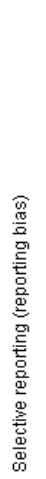 & 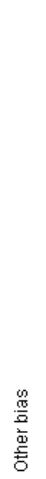 & 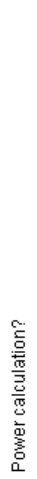 \\
\hline Boffard 2005a & $?$ & $?$ & $?$ & $?$ & ? & $\odot$ & $?$ & + \\
\hline Boffard 2005b & $?$ & $?$ & $?$ & $?$ & $\odot$ & $\odot$ & $?$ & 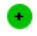 \\
\hline Bosch 2004 & $\odot$ & $\odot$ & $\odot$ & $\odot$ & $\odot$ & $?$ & $\odot$ & $\odot$ \\
\hline Bosch 2008 & $\odot$ & $\odot$ & $\odot$ & $\odot$ & $\odot$ & $\odot$ & $?$ & $\odot$ \\
\hline Chuansumrit 2005 & $?$ & $?$ & $\odot$ & $\odot$ & $?$ & $?$ & $?$ & ○ \\
\hline Diprose 2005 & + & $?$ & + & + & + & $?$ & $\odot$ & 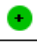 \\
\hline Ekert 2006 & $?$ & $?$ & $\odot$ & $\odot$ & $\odot$ & $?$ & $\odot$ & $\Rightarrow$ \\
\hline Essam 2007 & $?$ & $?$ & $?$ & $?$ & $\odot$ & $?$ & $?$ & 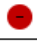 \\
\hline Friederich 2003 & $\bullet$ & 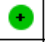 & $\odot$ & $\odot$ & $\odot$ & $?$ & $?$ & $?$ \\
\hline Gill 2009 & $\odot$ & + & + & $\odot$ & + & $?$ & $?$ & + \\
\hline Hanna 2010 & $?$ & $?$ & $?$ & $?$ & $?$ & $?$ & $?$ & $?$ \\
\hline Hauser $2010 a$ & + & + & + & $?$ & + & $?$ & $?$ & + \\
\hline Hauser $2010 \mathrm{~b}$ & + & + & + & $?$ & + & $?$ & $?$ & + \\
\hline Jeffers 2002 & + & $?$ & + & + & $\odot$ & $?$ & $?$ & $?$ \\
\hline Johansson 2007 & + & $?$ & $?$ & $?$ & $\odot$ & $?$ & $?$ & $\odot$ \\
\hline Lodge 2005a & $\odot$ & + & $\odot$ & $\odot$ & $\odot$ & $?$ & $\odot$ & 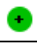 \\
\hline Lodge 2005b & $?$ & $?$ & $?$ & $?$ & $?$ & $?$ & $?$ & $\odot$ \\
\hline Ma 2006 & $\odot$ & $?$ & $?$ & $?$ & $\odot$ & $?$ & $?$ & $\odot$ \\
\hline Mayer 2005a & $\odot$ & + & + & $\odot$ & + & $\odot$ & $?$ & $?$ \\
\hline Mayer 2005b & $?$ & $?$ & $\odot$ & $\odot$ & + & $?$ & $?$ & \\
\hline Mayer 2006 & $?$ & $?$ & $\odot$ & $\odot$ & $\odot$ & $?$ & $?$ & \\
\hline Mayer 2008 & $\odot$ & $?$ & $\odot$ & $\odot$ & $\odot$ & $\odot$ & + & 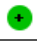 \\
\hline Narayan 2008 & $?$ & $?$ & $?$ & $\odot$ & $\odot$ & $\odot$ & $?$ & $\odot$ \\
\hline Pinusch 2005 & $\bullet$ & $\odot$ & + & $\odot$ & $\odot$ & $?$ & $\theta$ & 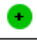 \\
\hline Planinsic 2005 & $?$ & $?$ & $\odot$ & $\odot$ & $\odot$ & $?$ & $\odot$ & 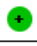 \\
\hline Pugliese 2007 & $?$ & $?$ & $?$ & $?$ & $\odot$ & $?$ & $?$ & - \\
\hline Raobaikady 2005 & + & $?$ & $?$ & $?$ & $\odot$ & $?$ & $\odot$ & 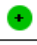 \\
\hline Sachs 2007 & $?$ & $?$ & + & $\odot$ & $?$ & $?$ & $?$ & + \\
\hline Shao 2006 & $?$ & $?$ & $?$ & $?$ & $\odot$ & $?$ & 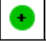 & $?$ \\
\hline
\end{tabular}




\section{Prophylactic trials}

All prophylactic studies had some threats to validity. For the most part, these potential risks of bias were due to lack of detail provided on the specific criteria and thus were judged as 'unclear'. Using the Cochrane grading system:

- sequence generation was adequate in eight studies and unclear in eight;

- allocation concealment was adequate in three studies and unclear in 13;

- blinding of participants and personnel was adequate in nine studies and unclear in seven;

- blinding of outcome assessment was adequate in nine studies and unclear in seven;

- incomplete outcome data assessment was adequate in 13 studies and unclear in three;

- free of selective outcome reporting assessment was unclear in all studies as study protocols were not available and none of the studies were found to be registered with a clinical trials registry;

- free of other bias assessment was adequate in five studies, unclear in 10 and inadequate in one. The study judged to be inadequate in this category was Diprose 2005 in which there were baseline differences between rFVIIa and placebo groups and the study was underpowered; and

- power calculation was adequate in seven studies, unclear in four and inadequate in five. The studies judged to be inadequate had not performed power calculations.

Two prophylactic trials (Gill 2009; Lodge 2005a) had minimal threats to validity.

\section{Therapeutic trials}

For therapeutic studies, the potential risks of bias were mostly due to lack of detail provided on the specific criteria and we thus judged them as 'unclear'. Using the Cochrane grading system:

- sequence generation was adequate in seven studies and unclear in six;

- allocation concealment was adequate in six studies and unclear in seven;

- blinding of participants and personnel was adequate in 10 studies and unclear in three;

- blinding of outcome assessment was adequate in nine studies and unclear in four;

- incomplete outcome data assessment was adequate in 11 studies and unclear in two;
- free of selective outcome reporting assessment was adequate in seven studies (registered with a clinical trials registry), unclear in four studies and inadequate in two studies. The two studies judged to be inadequate were Boffard 2005a and Boffard 2005b where emphasis was placed on the analysis where patients who died within 48 hours were excluded and data for some outcomes were presented for those patients alive at 48 hours;

- free of other bias assessment was adequate in two studies, unclear in 10 and inadequate in one. The study judged to be inadequate was Pihusch 2005 in which there were baseline differences between rFVIIa and placebo groups;

- power calculation was adequate in eight studies, unclear in one and inadequate in four studies where no power calculations were performed.

All 13 RCTs using rFVIIa to treat established bleeding were reported to be double-blind and placebo-controlled, but two (Bosch 2004; Bosch 2008) were felt to be largely free from threats to validity.

When compared to the prophylactic trials, the therapeutic trials were less prone to bias, particularly in the areas of blinding and selective reporting as judged by being registered clinical trials. Therapeutic trials were also on average larger in sample size than prophylactic trials.

\section{Effects of interventions}

\section{See: Summary of findings for the main comparison}

\section{Prophylactic trials}

\section{Death}

Mortality data were included for 15 trials. The individual results from all 15 studies had a $95 \%$ confidence interval (CI) that included 1.0 (no difference between rFVIIa and placebo). The pooled risk ratio (RR) was 1.04 (95\% CI 0.55 to 1.97 ), $\mathrm{I}^{2}=0 \%$, indicating that observed variation in the study results was compatible with chance alone (Figure 4). In six studies (Ekert 2006; Essam 2007; Friederich 2003; Hanna 2010; Pugliese 2007; Raobaikady 2005) no deaths were mentioned; thus the number of deaths was taken to be zero in all study arms. Control arm death rates were generally low across all studies, the maximum being $1 / 10$ (Diprose 2005). 
Figure 4. Forest plot of comparison: I rFVIla used prophylactically versus placebo, outcome: I.I Death.

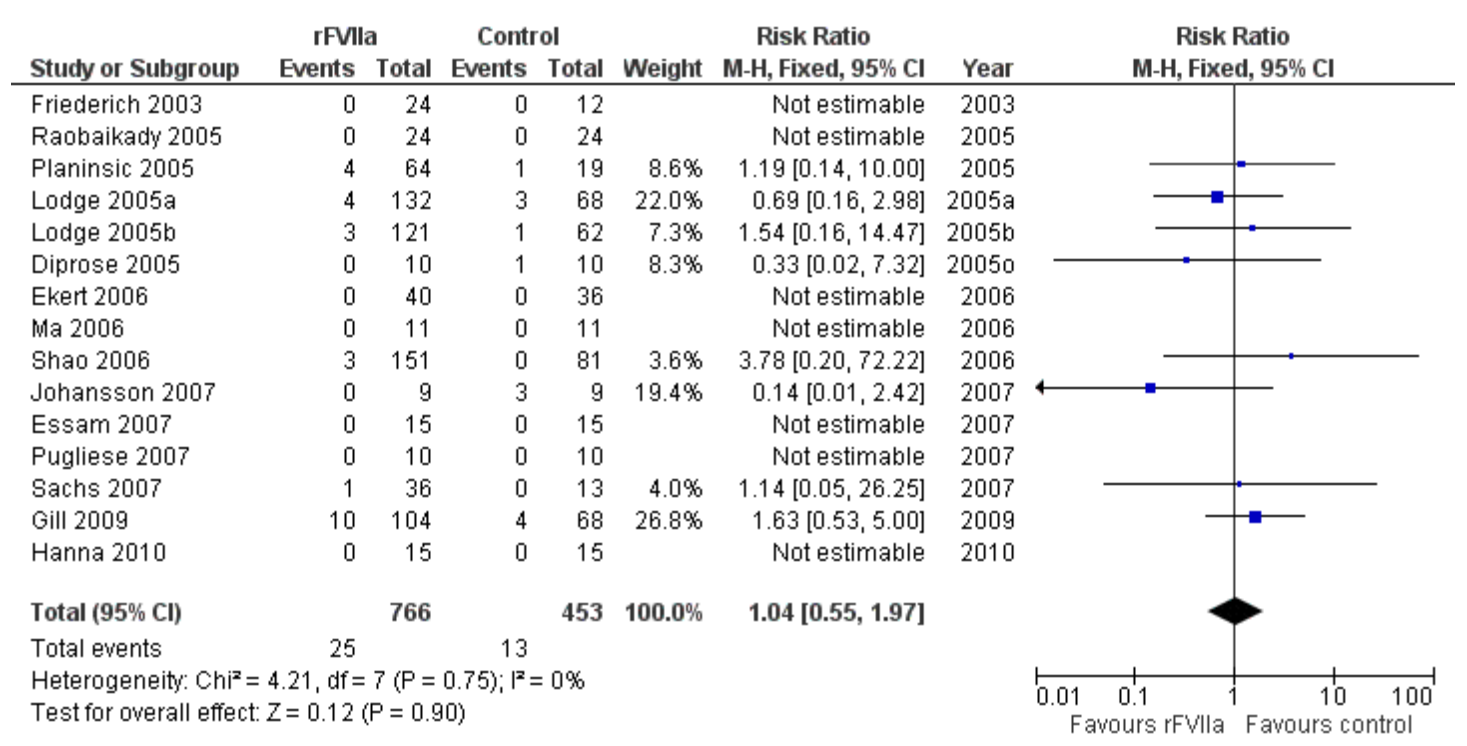

\section{Blood loss}

Ten studies contributed blood loss outcome data. The pooled mean difference (MD) was $-297 \mathrm{~mL}(297 \mathrm{~mL}$ less blood loss in the rFVIIa arms) (95\% CI -416 to -178) (Analysis 1.3). There was marked variation in the amount of mean blood loss in the control arms, from $381 \mathrm{~mL}$ (Ma 2006) to $8552 \mathrm{~mL}$ (Lodge 2005b). Five studies, each with fewer than 40 patients, had a 95\% CI not including zero favouring rFVIIa (Essam 2007; Friederich 2003; Hanna 2010; Ma 2006; Pugliese 2007). These studies accounted for $20 \%$ of the included patients in the analysis but their MDs accounted for $82 \%$ of the pooled estimate.

Investigation of the heterogeneity is presented in Analysis 1.4. Heterogeneity was explained in part by the size of the study. When only studies with greater than 50 patients (Gill 2009; Lodge 2005a; Lodge 2005b; Sachs 2007) were included, the $I^{2}=0 \%$ and the pooled MD was no longer statistically significant (MD -261 mL; $95 \%$ CI -550 to 28 ).

The pooled MD likely represents an overestimate of the effect of rFVIIa as four additional studies, each with more than 40 patients, reported no difference in blood loss and could not be incorpo-

rated into the pooled analysis because outcomes were not available as mean/standard deviation (SD) (Ekert 2006; Planinsic 2005; Raobaikady 2005; Shao 2006). The blood loss data were affected by heavy weighting towards several small studies that reported very precise estimation of blood losses.

\section{Use of red cell transfusion}

Twelve studies were included in the pooled analysis for red cell transfusion requirements. The pooled MD was $-261 \mathrm{~mL}(261$ $\mathrm{mL}$ less red cells required in the rFVIIa arms) (95\% CI -367 to 154) (Figure 5). There was evidence of significant heterogeneity $\left(\mathrm{I}^{2}=62 \%\right)$. Data in units of red cells were converted to millilitres assuming a single unit equated to $300 \mathrm{~mL}$. There was marked variation in the amount of mean red cell transfusion requirements in the control arm, from $450 \mathrm{~mL}$ (Friederich 2003) to $5820 \mathrm{~mL}$ (Johansson 2007). Six studies had a 95\% CI not including zero and favouring rFVIIa (Essam 2007; Friederich 2003; Hanna 2010; Johansson 2007; Ma 2006; Pugliese 2007) and none had more than 50 patients. Studies with fewer than 50 patients accounted for $26 \%$ of the included patients in the analysis but their MDs accounted for $81 \%$ of the pooled estimate. 
Figure 5. Forest plot of comparison: I rFVIla used prophylactically versus placebo, outcome: I.5 Red cell transfusion requirements $(\mathrm{mL})$.

\begin{tabular}{|c|c|c|c|c|c|c|c|c|c|c|c|}
\hline \multirow[b]{2}{*}{ Study or Subgroup } & \multicolumn{3}{|c|}{ rFVlla } & \multicolumn{3}{|c|}{ Control } & \multicolumn{3}{|c|}{ Mean Difference } & \multirow{2}{*}{\multicolumn{2}{|c|}{$\begin{array}{c}\text { Mean Difference } \\
\text { IV, Random, 95\% Cl }\end{array}$}} \\
\hline & Mean & SD & Total & Mean & SD & Total & Weight & IV, Random, $95 \% \mathrm{Cl}$ & Year & & \\
\hline Planinsic 2005 & 3,332 & 3,704 & 63 & 3,330 & 2,250 & 19 & $0.6 \%$ & $2.00[-1361.86,1365.86]$ & 2005 & & \\
\hline Lodge $2005 \mathrm{~b}$ & 3,444 & 4,341 & 118 & 3,840 & 4,620 & 61 & $0.6 \%$ & $-396.00[-1795.15,1003.15]$ & $2005 b$ & $\longleftarrow$ & \\
\hline Diprose 2005 & 234 & 597 & 10 & 750 & 603 & 10 & $3.5 \%$ & $-516.00[-1041.92,9.92]$ & 20050 & & \\
\hline Ma 2006 & 1,050 & 660 & 11 & 1,890 & 930 & 11 & $2.3 \%$ & $-840.00[-1513.92,-166.08]$ & 2006 & & \\
\hline Essam 2007 & 317 & 334 & 15 & 517 & 176 & 15 & $13.3 \%$ & $-200.00[-391.06,-8.94]$ & 2007 & & \\
\hline Pugliese 2007 & 300 & 133 & 10 & 570 & 111 & 10 & $18.9 \%$ & $-270.00[-377.37,-162.63]$ & 2007 & & \\
\hline Gill 2009 (1) & 638 & 826 & 104 & 821 & 824 & 68 & $10.1 \%$ & $-183.00[-435.11,69.11]$ & 2009 & & \\
\hline Hanna 2010 & 375 & 106 & 15 & 612 & 114 & 15 & $20.7 \%$ & $-237.00[-315.78,-158.22]$ & 2010 & $\rightarrow$ & \\
\hline Total $(95 \% \mathrm{Cl})$ & & & 537 & & & 306 & $100.0 \%$ & $-260.78[-367.30,-154.27]$ & & & \\
\hline $\begin{array}{l}\text { Heterogeneity: Tau } \\
\text { Test for overall effect }\end{array}$ & $\begin{array}{l}12666 \\
Z=4.80\end{array}$ & $\begin{array}{l}09 ; \mathrm{Chi}^{2} \\
(\mathrm{P}<0 . \mathrm{C}\end{array}$ & $\begin{array}{l}=28.6 \\
00001)\end{array}$ & $7, d f=$ & $1(\mathrm{P}=$ & $1.003) ;$ & $=62 \%$ & & & $\begin{array}{c}1 \\
\text { Favours rFvlla }\end{array}$ & $\begin{array}{lll} & 5001000 \\
& \text { Favours control }\end{array}$ \\
\hline
\end{tabular}

Further investigation of the heterogeneity is presented in Analysis 1.6. Heterogeneity was explained in part by the size of the study. When only studies with greater than 50 patients (Gill 2009; Lodge 2005a; Lodge 2005b; Planinsic 2005) were included, the $\mathrm{I}^{2}=14 \%$ and the pooled MD was no longer statistically significant (MD $33 \mathrm{~mL}$; 95\% CI -260 to 193 ).

The pooled MD likely represents an overestimate of the effect of rFVIIa as three additional studies reported no difference in red cell requirements and could not be incorporated into the pooled analysis because outcomes were not available as mean/SD (Ekert 2006; Raobaikady 2005; Shao 2006). The red cell transfusion data was also affected by heavy weighting towards several small studies that reported very precise estimation of red cell transfusion requirements.

\section{Number of patients transfused}

of people requiring transfusion with rFVIIa.

\section{Thromboembolic events}

Thirteen studies contributed data on thromboembolic events. The pooled RR was 1.35 (95\% CI 0.82 to 2.25 ) with heterogeneity accounted for by chance alone $\left(\mathrm{I}^{2}=0 \%\right)$ (Analysis 1.9). Control event rates were generally low across all studies, the maximum being 2/10 (Diprose 2005). Individually the $95 \%$ CIs of all the included studies included 1.0 (no difference between rFVIIa and placebo). Essam 2007 was not included in the pooled analysis as no detail was provided on adverse events.

\section{Therapeutic trials}

Eight studies reported and contributed data on the number of patients transfused. The pooled RR was 0.85 (95\% CI 0.72 to 1.01) with marked heterogeneity present, $I^{2}=57 \%$ (Analysis 1.7). Further exploration offered no clear explanation for heterogeneity (Analysis 1.8). There was marked variation in the proportions of patients receiving transfusions in the control arms, ranging from $37 \%$ (Lodge 2005a) to 100\% (Lodge 2005b). Two studies had a 95\% CI that did not include 1.0 (no difference) (Friederich 2003; Lodge 2005b); both studies showed a reduction in the proportion

\section{Death}

All included studies contributed data on death. The pooled RR for overall mortality was 0.91 (95\% CI 0.78 to 1.06$)$ with no statistical heterogeneity $\left(\mathrm{I}^{2}=0 \%\right)$ (Figure 6$)$. The mortality rates in the control group varied from $0 / 9$ (Chuansumrit 2005) to 22/ 74 (30\%) (Boffard 2005a). All studies yielded a RR whose 95\% CI included 1.0 when examined in separate dose groups. However, in Mayer 2005a the RR was 0.63 (95\% CI 0.43 to 0.94 ). 
Figure 6. Forest plot of comparison: 2 rFVIla used therapeutically versus placebo, outcome: 2.I Death.

\begin{tabular}{|c|c|c|c|c|c|c|c|}
\hline \multirow{2}{*}{ Study or Subgroup } & \multicolumn{2}{|c|}{ Favours rFVla } & \multicolumn{2}{|c|}{ Control } & \multirow{2}{*}{ Weight } & \multirow{2}{*}{$\begin{array}{c}\text { Risk Ratio } \\
\text { M-H, Random, } 95 \% \mathrm{Cl}\end{array}$} & \multirow{2}{*}{$\begin{array}{c}\text { Risk Ratio } \\
\text { M-H, Random, } 95 \% \mathrm{Cl}\end{array}$} \\
\hline & Events & rotal & Events & Total & & & \\
\hline Bosch 2004 & 16 & 116 & 11 & 120 & $4.8 \%$ & $1.50[0.73,3.10]$ & 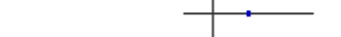 \\
\hline Boffard 2005a & 17 & 69 & 22 & 74 & $8.5 \%$ & $0.83[0.48,1.42]$ & \\
\hline Boffard 2005b & 17 & 70 & 18 & 64 & $7.7 \%$ & $0.86[0.49,1.53]$ & \\
\hline Chuansumrit 2005 & 0 & 16 & 0 & 9 & & Not estimable & \\
\hline Mayer $2005 a$ & 56 & 303 & 28 & 96 & $16.3 \%$ & $0.63[0.43,0.94]$ & \\
\hline Mayer 2005b & 3 & 36 & 2 & 11 & $0.9 \%$ & $0.46[0.09,2.40]$ & \\
\hline Pihusch 2005 & 24 & 77 & 7 & 23 & $5.1 \%$ & $1.02[0.51,2.07]$ & \\
\hline Mayer 2006 & 7 & 32 & 1 & 8 & $0.7 \%$ & $1.75[0.25,12.26]$ & \\
\hline Bosch 2008 & 39 & 170 & 25 & 86 & $13.5 \%$ & $0.79[0.51,1.21]$ & \\
\hline Mayer 2008 & 112 & 557 & 51 & 262 & $28.4 \%$ & $1.03[0.77,1.39]$ & \\
\hline Narayan 2008 & 7 & 61 & 4 & 36 & $1.9 \%$ & $1.03[0.32,3.29]$ & \\
\hline Hauser $2010 a$ & 26 & 224 & 28 & 250 & $9.9 \%$ & $1.04[0.63,1.71]$ & \\
\hline Hauser 2010b & 8 & 46 & 5 & 40 & $2.3 \%$ & $1.39[0.49,3.91]$ & \\
\hline Total $(95 \% \mathrm{Cl})$ & & 1777 & & 1079 & $100.0 \%$ & $0.91[0.78,1.06]$ & \\
\hline Total events & 332 & & 202 & & & & \\
\hline \multicolumn{7}{|c|}{$\begin{array}{l}\text { Heterogeneity: } \text { Tau }^{2}=0.00 ; \mathrm{Chi}^{2}=8.62, \mathrm{df}=11(\mathrm{P}=0.66) ; \mathrm{I}^{2}=0 \% \\
\text { Test for overall effect: } Z=1.18(P=0.24)\end{array}$} & 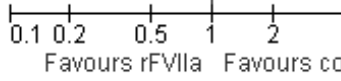 \\
\hline
\end{tabular}

\section{Control of bleeding}

Seven trials reported outcome data on the control of bleeding, four of which (Bosch 2004; Bosch 2008; Chuansumrit 2005; Pihusch 2005) provided data appropriate for meta-analysis. The pooled RR was 0.95 (95\% CI 0.88 to 1.03$)$ in favour of rFVIIa, with $\mathrm{I}^{2}=0 \%$ (Analysis 2.3). The proportion of participants achieving bleeding control in the placebo arm ranged from $44 \%$ (Chuansumrit 2005) to $84 \%$ (Bosch 2004). For all the included studies, the RR 95\% CI included 1.0 (no difference).

The five intracranial haemorrhage (ICH) randomised controlled trials (RCTs) (Mayer 2005a; Mayer 2005b; Mayer 2006; Mayer 2008; Narayan 2008) measured bleeding control in a different way from the other studies. Although appropriate to the condition they addressed, this meant that their results could not be combined quantitatively. We thus considered the additional insights they provided qualitatively alongside the above pooled RR. In the initial efficacy study (Mayer 2005a), the trial authors reported a statistically significant reduction in the growth of haemorrhage volume in favour of rFVIIa. Additional data provided suggested that reductions in the increase in haemorrhage volume attributable to rFVIIa were associated with reduced disability as measured by the Modified Rankin Scale, the Extended Glasgow Coma Scale, the Barthel Index and the National Institutes of Health Stroke Scale at 90 days. The second efficacy trial (Mayer 2008) defined its primary endpoint as severe disability or death by a Modified Rankin scale score of 5 or 6 . Although this study did show a significant reduction in growth of volume of haemorrhage in the 80 $\mu \mathrm{g} / \mathrm{kg}$ rFVIIa group, there was no significant difference in the primary endpoint at 90 days. None of the safety trials (Mayer 2005b; Mayer 2006; Narayan 2008) showed a significant reduction in their secondary endpoints of growth of volume of haemorrhage.

\section{Use of red cell transfusion}

Five studies contributed data on the use of red cell transfusions (Bosch 2004; Bosch 2008; Chuansumrit 2005; Hauser 2010a; Hauser 2010b). The pooled MD was $-89 \mathrm{~mL}$ (95\% CI -264 to 87 ) with minimal heterogeneity $\left(I^{2}=16 \%\right.$ ) (Figure 7 ). The use of transfusion in the control groups varied from $103 \mathrm{~mL}$ (Chuansumrit 2005) to $2730 \mathrm{~mL}$ (Hauser 2010a). The 95\% CI for the MD for all the included studies included zero (no difference). 
Figure 7. Forest plot of comparison: 2 rFVIla used therapeutically versus placebo, outcome: 2.5 Red cell transfusion requirements $(\mathrm{mL})$.

\begin{tabular}{|c|c|c|c|c|c|c|c|c|c|c|}
\hline \multirow[b]{2}{*}{ Study or Subgroup } & \multicolumn{3}{|c|}{ rFVla } & \multicolumn{3}{|c|}{ Control } & \multicolumn{3}{|c|}{ Mean Difference } & \multirow{2}{*}{$\begin{array}{c}\text { Mean Difference } \\
\text { IV, Random, 95\% Cl }\end{array}$} \\
\hline & Mean & SD & Total & Mean & SD & Total & Weight & IV, Random, $95 \% \mathrm{Cl}$ & Year & \\
\hline Bosch 2004 & 450 & 1,110 & 121 & 390 & 570 & 121 & $41.1 \%$ & $60.00[-162.33,282.33]$ & 2004 & \\
\hline Chuansumrit 2005 (1) & 131 & 812 & 16 & 103 & 102 & 9 & $16.3 \%$ & $28.00[-375.41,431.41]$ & 2005 & \\
\hline Bosch 2008 & 764 & 719 & 76 & 990 & 930 & 75 & $32.1 \%$ & $-226.00[-491.39,39.39]$ & 2008 & \\
\hline Hauser $2010 a$ & 2,340 & 3,180 & 191 & 2,730 & 3,390 & 228 & $7.3 \%$ & $-390.00[-1020.09,240.09]$ & 2010 & \\
\hline Hauser 2010b & 1,500 & 2,220 & 39 & 2,040 & 2,070 & 35 & $3.1 \%$ & $-540.00[-1517.62,437.62]$ & 2010 & $\leftarrow$ \\
\hline Total $(95 \% \mathrm{Cl})$ & & & 443 & & & 468 & $100.0 \%$ & $-88.60[-263.88,86.68]$ & & \\
\hline $\begin{array}{l}\text { Heterogeneity: } \operatorname{Tau}^{2}=6 \\
\text { Test for overall effect: } Z\end{array}$ & $\begin{array}{l}73.65 ; \mathrm{C} \\
0.99(\mathrm{P}\end{array}$ & $\begin{array}{l}\mathrm{hi}^{2}=4.7 \\
=0.32)\end{array}$ & $74, d f=$ & $4(P=$ & $0.32) ; 1^{2}=$ & $=16 \%$ & & & & 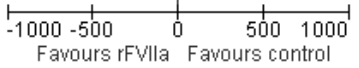 \\
\hline
\end{tabular}

Data from Boffard 2005a and Boffard 2005b were reported as median/range, therefore these could not be incorporated into the pooled analysis. The exclusion of these studies is unlikely to change the pooled MD as there was no significant difference in the primary endpoint of number of red cell units transfused for all patients at 48 hours.

\section{Number of patients transfused}

Three of the 13 studies investigating the use of rFVIIa for treating bleeding collected information on the number of patients transfused (Chuansumrit 2005; Hauser 2010a; Hauser 2010b). These studies showed a trend to a lower number of transfused patients in the rFVIIa treatment groups (RR 0.94; 95\% CI 0.89 to 1.00 ) (Analysis 2.7).

\section{Thromboembolic events}

All of the treatment trials contributed data on thromboembolic events. The pooled RR was 1.14 (95\% CI 0.89 to 1.47$)$ with no heterogeneity beyond chance expectation $\left(\mathrm{I}^{2}=0 \%\right.$ ) (Analysis 2.8). Control event rates were generally low across all studies, the maximum being 3/8 (Mayer 2006). Individually the 95\% CIs of all the included studies included 1.0 (no difference between rFVIIa and placebo).

\section{Thromboembolic events across all RCTs}

Twenty-six studies were available from prophylactic and therapeutic study groups to contribute to an overall combined estimate of the risk of thromboembolic events. The pooled RR was 1.18 ( $95 \%$ CI 0.94 to 1.48 ) with no observed heterogeneity $\left(\mathrm{I}^{2}=0 \%\right)$ (Figure 8). When considered as individual outcomes, there was no difference in cardiovascular, stroke or venous events. However, there was a significant increase in arterial thromboembolic events (RR 1.45; 95\% CI 1.02 to 2.05) (Figure 9). 
Figure 8. Forest plot of comparison: 3 rFVIla used prophylactically or therapeutically versus placebo (adverse events), outcome: 3.1 Total thromboembolic events.

\begin{tabular}{|c|c|c|c|c|c|c|c|c|}
\hline Study or Subgroup & \multicolumn{2}{|c|}{ rFVlla } & Control & Total & Weight & $\begin{array}{c}\text { Risk Ratio } \\
\text { M-H, Random, } 95 \% \mathrm{Cl}\end{array}$ & \multicolumn{2}{|c|}{$\begin{array}{c}\text { Risk Ratio } \\
\text { M-H, Random, } 95 \% \mathrm{Cl}\end{array}$} \\
\hline Friederich 2003 & 1 & 24 & 0 & 12 & $0.5 \%$ & $1.56[0.07,35.67]$ & $\longleftarrow$ & $\longrightarrow$ \\
\hline Planinsic 2005 & 8 & 64 & 3 & 19 & $3.4 \%$ & $0.79[0.23,2.69]$ & & \\
\hline Bosch 2004 & 7 & 121 & 7 & 121 & $5.0 \%$ & $1.00[0.36,2.76]$ & & \\
\hline Boffard 2005a & 2 & 69 & 3 & 74 & $1.7 \%$ & $0.71[0.12,4.15]$ & & \\
\hline Boffard 2005b & 4 & 70 & 3 & 64 & $2.4 \%$ & $1.22[0.28,5.24]$ & & \\
\hline Chuansumrit 2005 & 0 & 16 & 0 & 9 & & Not estimable & & \\
\hline Diprose 2005 & 2 & 10 & 2 & 10 & $1.7 \%$ & $1.00[0.17,5.77]$ & & \\
\hline Lodge 2005a & 6 & 132 & 3 & 68 & $2.8 \%$ & $1.03[0.27,3.99]$ & & \\
\hline Lodge 2005b & 19 & 121 & 6 & 62 & $6.9 \%$ & $1.62[0.68,3.85]$ & & \\
\hline Mayer 2005a & 21 & 303 & 2 & 96 & $2.5 \%$ & $3.33[0.79,13.93]$ & & \\
\hline Mayer 2005b & 5 & 36 & 1 & 11 & $1.2 \%$ & $1.53[0.20,11.73]$ & & \\
\hline Pihusch 2005 & 8 & 77 & 0 & 23 & $0.6 \%$ & $5.23[0.31,87.34]$ & & \\
\hline Raobaikady 2005 & 0 & 24 & 0 & 24 & & Not estimable & & \\
\hline Ekert 2006 & 0 & 40 & 0 & 36 & & Not estimable & & \\
\hline $\operatorname{Ma} 2006$ & 0 & 11 & 0 & 11 & & Not estimable & & \\
\hline Mayer 2006 & 7 & 32 & 3 & 8 & $4.2 \%$ & $0.58[0.19,1.77]$ & & \\
\hline Shao 2006 & 3 & 151 & 1 & 81 & $1.0 \%$ & $1.61[0.17,15.22]$ & & \\
\hline Johansson 2007 & 0 & 9 & 0 & 9 & & Not estimable & & \\
\hline Pugliese 2007 & 0 & 10 & 0 & 10 & & Not estimable & & \\
\hline Sachs 2007 & 8 & 36 & 2 & 13 & $2.6 \%$ & $1.44[0.35,5.94]$ & & \\
\hline Bosch 2008 & 9 & 176 & 7 & 89 & $5.6 \%$ & $0.65[0.25,1.69]$ & & \\
\hline Mayer 2008 & 55 & 558 & 21 & 263 & $22.2 \%$ & $1.23[0.76,2.00]$ & & \\
\hline Narayan 2008 & 13 & 61 & 5 & 36 & $5.7 \%$ & $1.53[0.60,3.95]$ & & \\
\hline Gill 2009 & 7 & 104 & 1 & 68 & $1.2 \%$ & $4.58[0.58,36.38]$ & & \\
\hline Hauser $2010 a$ & 36 & 224 & 33 & 250 & $26.9 \%$ & $1.22[0.79,1.88]$ & & \\
\hline Hauser $2010 b$ & 2 & 46 & 4 & 40 & $1.9 \%$ & $0.43[0.08,2.25]$ & $\longleftarrow$ & \\
\hline Total $(95 \% \mathrm{Cl})$ & & 2525 & & 1507 & $100.0 \%$ & $1.18[0.94,1.48]$ & & \\
\hline Total events & 223 & & 107 & & & & & \\
\hline $\begin{array}{l}\text { Heterogeneity: Tau } \\
\text { Test for overall effec }\end{array}$ & $\begin{array}{l}0.00 ; \mathrm{Chi} \\
\mathrm{Z}=1.450\end{array}$ & $\begin{array}{l}\mathrm{i}^{2}=11 . \\
(P=0.1\end{array}$ & $\begin{array}{l}40, \mathrm{df}=1 \\
5)\end{array}$ & $9(P=0$ & $9.91) ;\left.\right|^{2}=$ & $0 \%$ & 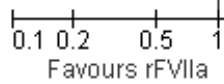 & 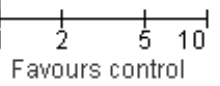 \\
\hline
\end{tabular}


Figure 9. Forest plot of comparison: 3 rFVIla used prophylactically or therapeutically versus placebo (adverse events), outcome: 3.4 Total arterial events.

\begin{tabular}{|c|c|c|c|c|c|c|c|c|}
\hline Study or Subgroup & \multicolumn{2}{|c|}{ rFVla } & \multicolumn{2}{|c|}{ Control } & Weight & $\begin{array}{c}\text { Risk Ratio } \\
\text { M-H, Random, } 95 \% \text { Cl }\end{array}$ & \multicolumn{2}{|c|}{$\begin{array}{c}\text { Risk Ratio } \\
\text { M-H, Random, } 95 \% \mathrm{Cl}\end{array}$} \\
\hline Planinsic 2005 & 6 & 64 & 2 & 19 & $5.3 \%$ & $0.89[0.20,4.06]$ & & \\
\hline Friederich 2003 & 1 & 24 & 0 & 12 & $1.2 \%$ & $1.56[0.07,35.67]$ & & \\
\hline Bosch 2004 & 2 & 121 & 0 & 121 & $1.3 \%$ & $5.00[0.24,103.07]$ & & \\
\hline Boffard 2005a & 1 & 69 & 0 & 74 & $1.2 \%$ & $3.21[0.13,77.60]$ & & \\
\hline Boffard 2005b & 2 & 70 & 1 & 64 & $2.1 \%$ & $1.83[0.17,19.69]$ & & \\
\hline Chuansumrit 2005 & 0 & 16 & 0 & 9 & & Not estimable & & \\
\hline Diprose 2005 & 2 & 10 & 2 & 10 & $3.9 \%$ & $1.00[0.17,5.77]$ & & \\
\hline Lodge 2005a & 2 & 132 & 0 & 68 & $1.3 \%$ & $2.59[0.13,53.28]$ & & \\
\hline Mayer 2005a & 16 & 303 & 0 & 96 & $1.5 \%$ & $10.53[0.64,173.88]$ & & \\
\hline Mayer 2005b & 4 & 36 & 0 & 11 & $1.5 \%$ & $2.92[0.17,50.37]$ & & \\
\hline Pihusch 2005 & 5 & 77 & 0 & 23 & $1.5 \%$ & $3.38[0.19,59.02]$ & & \\
\hline Raobaikady 2005 & 0 & 24 & 0 & 24 & & Not estimable & & \\
\hline Ekert 2006 & 0 & 40 & 0 & 36 & & Not estimable & & \\
\hline Ma 2006 & 0 & 11 & 0 & 11 & & Not estimable & & \\
\hline Mayer 2006 & 4 & 32 & 3 & 8 & $7.4 \%$ & $0.33[0.09,1.20]$ & & \\
\hline Shao 2006 & 1 & 151 & 0 & 81 & $1.2 \%$ & $1.62[0.07,39.28]$ & & \\
\hline Johansson 2007 & 0 & 9 & 0 & 9 & & Not estimable & & \\
\hline Pugliese 2007 & 0 & 10 & 0 & 10 & & Not estimable & & \\
\hline Sachs 2007 & 8 & 36 & 2 & 13 & $6.0 \%$ & $1.44[0.35,5.94]$ & & \\
\hline Bosch 2008 & 3 & 176 & 0 & 89 & $1.4 \%$ & $3.56[0.19,68.16]$ & & \\
\hline Mayer 2008 & 39 & 558 & 11 & 263 & $28.3 \%$ & $1.67[0.87,3.21]$ & & \\
\hline Narayan 2008 & 6 & 61 & 4 & 36 & $8.4 \%$ & $0.89[0.27,2.93]$ & & \\
\hline Gill 2009 & 4 & 104 & 1 & 68 & $2.6 \%$ & $2.62[0.30,22.90]$ & & \\
\hline Hauser $2010 a$ & 16 & 224 & 11 & 250 & $21.7 \%$ & $1.62[0.77,3.42]$ & & \\
\hline Hauser 2010 b & 2 & 46 & 1 & 40 & $2.2 \%$ & $1.74[0.16,18.47]$ & & \\
\hline Total $(95 \% \mathrm{Cl})$ & & 2404 & & 1445 & $100.0 \%$ & $1.45[1.02,2.05]$ & & \\
\hline Total events & 124 & & 38 & & & & & \\
\hline $\begin{array}{l}\text { Heterogeneity: Tau }{ }^{2} \\
\text { Test for overall effect }\end{array}$ & $\begin{array}{l}0.00 ; \mathrm{Chi}^{-} \\
\mathrm{Z}=2.100\end{array}$ & $\begin{array}{l}P=11.3 \\
P=0.0\end{array}$ & $\begin{array}{l}34, d f=18 \\
\text { 4) }\end{array}$ & $8(P=0$ & $0.88) ;\left.\right|^{2}=0$ & $0 \%$ & 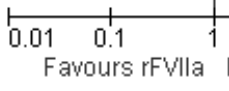 & $\begin{array}{c}10 \\
\text { Favours co }\end{array}$ \\
\hline
\end{tabular}

\section{Publication bias}

We assessed publication bias for each of the outcomes above. In the prophylactic studies, there was little or no asymmetry except for the outcome number of patients transfused. The funnel plot for the analysis number of patients transfused suggested that there may be small missing studies with RR > 1.0 (favouring placebo) (Figure 10). In the therapeutic studies, there was no marked asymmetry in the funnel plots. 
Figure 10. Funnel plot of comparison: I rFVIla used prophylactically versus placebo, outcome: I.7 Numbers of patients transfused.

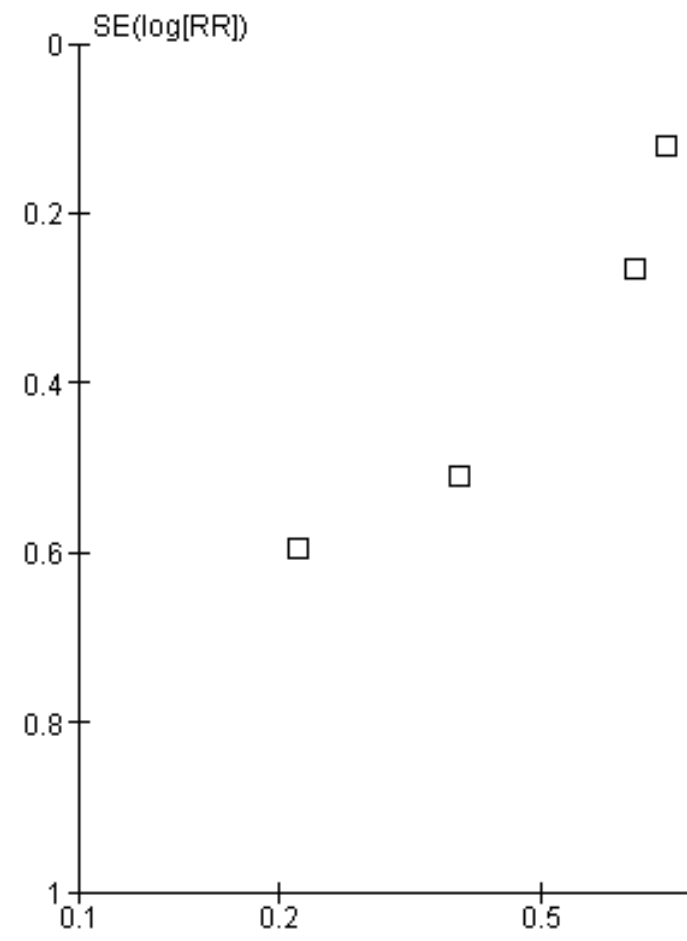

As noted in the methods section, we did review ongoing studies from our previous update. There has been no reported progress in ongoing studies since the last review despite adequate time for recruitment. This may also be a potential source of publication bias.

How does this update differ from the previous review?

\section{Results: potential benefits of rFVIla}

There was no evidence of a significant mortality benefit with the use of rFVIIa. This finding remains unchanged compared to the previous version of this review (Lin 2011), despite the addition of recent RCTs. In this updated version of the review, the risk of mortality associated with the prophylactic use of rFVIIa changed from a RR of 1.06 (95\% CI 0.50 to 2.24) to a RR of 1.04 (95\% CI 0.55 to 1.97$)$. For therapeutic studies, the trend towards decreased mortality in the previous Cochrane review with a RR of $0.89(95 \%$ CI 0.77 to 1.03 ) is similar to the current review with a RR of 0.92 (95\% CI 0.79 to 1.08 ). Looking at the individual studies, Mayer 2005a was the only study that showed a mortality benefit and in this study, mortality was a secondary outcome. The sub- sequent phase III clinical trial in spontaneous ICH (Mayer 2008) was unable to show an improvement in survival or functional outcome, even though a reduction in haematoma growth was seen. The group receiving $80 \mu \mathrm{g} / \mathrm{kg}$ rFVIIa was found to have a more frequent rate of arterial events when compared to placebo. The question as to whether there may be clinical benefit in a subgroup of high-risk patients with spontaneous ICH is being addressed in two registered clinical trials which, at the time of writing, have just begun recruiting (Flaherty 2008; Gladstone 2011).

As in the previous Cochrane review (Lin 2011), the volume of perioperative blood loss and red cell transfusions for the prophylactic trials remained statistically significant in favour of rFVIIa. However, there was evidence of important statistical heterogeneity for these studies.

In this version, although not statistically significant, there is a trend towards a lower number of patients transfused favouring rFVIIa in the included eight prophylactic trials (RR 0.85; 95\% CI 0.72 to 1.01 ) and three therapeutic trials (RR $0.94 ; 95 \%$ CI 0.89 to 1.00 ) compared to the previous version (prophylactic RR 0.91; 95\% CI 0.82 to 1.02 and therapeutic RR $0.94 ; 95 \%$ CI 0.29 to 3.04). For the prophylactic estimate, potential publication bias may overestimate the benefit of rFVIIa. 


\section{Results: potential risks of $\mathrm{rFVIIa}$}

In this review, thromboembolic events were not statistically increased in prophylactic (RR 1.35; 95\% CI 0.82 to 2.25 ) or therapeutic (RR 1.14; 95\% CI 0.89 to 1.47 ) studies. Pooling adverse events across both prophylactic and therapeutic studies did lead to an increase in arterial thromboembolic events (RR 1.45; 95\% CI 1.02 to 2.05) (Figure 9), which is a new finding compared to the previous version.

\section{DISCUSSION}

\section{Summary of main results}

Sixteen trials including a total of 1361 participants examined the use of rFVIIa prophylactically to prevent bleeding. The studies were conducted in a range of clinical situations including cardiac surgery; liver biopsy; partial hepatectomy; liver transplantation; prostatectomy; burns excision; pelvic reconstruction; craniofacial reconstruction and spinal surgery. The main outcomes were mortality, blood loss, red cell transfusion requirements, numbers transfused and thromboembolic adverse events. All studies were randomised controlled trials (RCTs), but many were prone to bias, particularly through lack of clarity about how participants were randomised. There was no effect on mortality (risk ratio (RR) 1.04; $95 \%$ confidence interval (CI) 0.55 to 1.97 ). Modest benefits were found in the outcomes of blood loss and red cell transfusion requirements (less than one red cell unit saved with rFVIIa treatment); however, these favourable findings were likely overestimated because data were not available from larger negative studies for inclusion in the meta-analysis. A statistically non-significant trend towards an increased risk of thromboembolic events with rFVIIa was also observed (see 'Summary of findings for the main comparison').

Thirteen trials including a total of 2929 participants examined the therapeutic role of rFVIIa for the treatment of bleeding. Again the studies were conducted in a range of different clinical scenarios including blunt and penetrating trauma; gastrointestinal haemorrhage; Dengue haemorrhagic fever; intracranial haemorrhage (ICH) and stem cell transplantation. There was no difference in the outcomes of mortality (RR $0.91 ; 95 \%$ CI 0.78 to 1.06 ), control of bleeding, red cell transfusion requirements, numbers transfused and thromboembolic adverse events. All studies were placebo-controlled, double-blind RCTs. Two trials (Bosch 2004; Bosch 2008) were substantially free from bias; the remainder had threats, particularly lack of detail about randomisation. None of the pooled outcomes showed reliable evidence of an advantage (or disadvantage in the case of adverse events) of rFVIIa over placebo. However, there were trends towards decreased mortality, decreased number of patients transfused and increased thromboembolic adverse events with rFVIIa treatment (see 'Summary of findings for the main comparison').
Although there were no differences seen in the total thromboembolic adverse events, when arterial thrombotic events were considered for all studies combined, a statistically significant increase was observed (RR 1.45; 95\% CI 1.02 to 2.05).

\section{Quality of the evidence}

Issues relating to methodological quality of the trials have been described in the 'Risk of bias' figures (Figure 2 and Figure 3). Overall, all studies except four (Bosch 2004; Bosch 2008; Gill 2009; Lodge 2005a) had threats to validity. In most cases, the threats to validity were assessed as 'unclear' because details were not provided in the publications. Many of the studies, in particular the prophylactic studies, were also hampered by inadequate power due to small sample size. The clinical settings in which more than one adequately powered trial was conducted included trauma, partial hepatectomy, liver transplantation, cirrhosis with upper gastrointestinal bleeding and spontaneous intracranial haemorrhage.

\section{Potential biases in the review process}

Concerning the validity of the findings of this systematic review, there are limitations. We were unable to obtain data from all authors to be used quantitatively in the meta-analysis and often the excluded studies were those that did not favour rFVIIa (specifically in the prophylactic trials, four RCTs in the outcome of total blood loss and three RCTs in the outcome of red cell transfusion requirements showed no difference between rFVIIa and placebo). In the therapeutic studies for the outcome control of bleeding, data from the intracranial haemorrhage studies could not be included in the pooled estimate because they expressed their results in a different manner (appropriately) from other therapeutic RCTs and so were considered qualitatively.

Publication bias remains possible. We examined funnel plots and detected publication bias in the outcome of number of patients transfused in the prophylactic RCTs where there were a lack of studies that favoured placebo over rFVIIa treatment. A potentially more significant source of publication bias was our inability to include unpublished but ongoing trials that have not been completed since the last version of this review.

\section{Agreements and disagreements with other studies or reviews}

The findings of this updated review extend and are consistent with other published meta-analyses. The relevant Cochrane systematic reviews include Marti-Carvajal 2007 and You 2006. Marti-Carvajal 2007 examined upper gastrointestinal bleeding (UGIB) in patients with liver disease but at the time of the review, the only RCT included was Bosch 2004. You 2006 considered haemostatic drugs for intracranial haemorrhage (ICH) and 
included the first three RCTs of rFVIIa in ICH (Mayer 2005a; Mayer 2005b; Mayer 2006) but not Mayer 2008. The meta-analysis showed reduction in risk of disability and death by the modified Rankin scale score but this was not consistent when an alternative outcome score (extended Glasgow Outcome Scale) was used. The use of rFVIIa was also balanced against a trend towards increased thromboembolic events. Ranucci 2008 performed a meta-analysis of $\mathrm{rFVIIa}$ in major surgical procedures and included seven of the prophylactic studies included in this review. They found a significant reduction in the risk of receiving allogeneic packed red blood cells (odds ratio (OR) 0.29 ; 95\% CI 0.10 to 0.80 ) although the absolute amount of red cell transfusion received was not analysed. Estimates of mortality and thromboembolic events were similar to the estimates in this review for prophylactic studies.

A recent systematic review published by Hsia 2008 reported similar estimates for mortality (OR 0.88 ; $95 \%$ CI 0.71 to 1.09 ) and thromboembolic events (OR 1.17; 95\% CI 0.87 to 1.58 ). Hsia 2008 also found that rFVIIa reduced the number of patients requiring additional red blood cell transfusion (OR 0.54; 95\%CI 0.34 to 0.86 ). In our current review, the absolute amount of red cell transfusion has been quantified; at least in the prophylactic setting, the estimated absolute amount of total blood loss or red cell transfusion requirement saved with rFVIIa treatment was less than one unit of red blood cells (RBCs) (the assumption in this review was that one red cell unit was equivalent to $300 \mathrm{~mL}$ ). However, this was likely to be an overestimate of the effect as data from negative studies could not be incorporated into the pooled analyses as described earlier in the results. In the therapeutic setting, Hsia 2008 identified one study (Boffard 2005a) of four included RCTs favouring rFVIIa for the outcome of additional red blood cell transfusion. The numbers used in the meta-analysis and reported in Boffard 2005a for this outcome were based on the percentage of patients alive at 48 hours receiving massive transfusion (more than 20 units of RBCs). The number of patients requiring massive transfusion for all patients was not provided in the publication. Thus, although there may be an advantage to rFVIIa in decreasing blood loss and red cell transfusion requirements, we believe that this advantage is small when the limitations of the data and the absolute amount of blood saved are considered.

In line with the findings of our Cochrane review, a recent metaanalysis of the off-label use of rFVIIa in cardiac surgery, liver transplantation, intracranial haemorrhage, trauma and prostatectomy showed no mortality benefit among patients who received rFVIIa (Yank 2011). In this review, the administration of rFVIIa was reported to increase the risk of arterial thromboembolism among patients with intracranial haemorrhage (risk difference (RD) 0.03; 95\% CI 0.01 to 0.06 and RD 0.06 ; $95 \%$ CI 0.01 to 0.11 for medium- and high-dose rFVIIa, respectively) and the rate of all thromboembolic events among cardiac surgery patients (RD 0.05; 95\% CI 0.01 to 0.10 ). Unlike previous studies of the off-label use of rFVIIa, Yank 2011 also reported a decreased risk of acute respiratory distress syndrome among body trauma patients who received rFVIIa (RD -0.05; 95\% CI -0.02 to -0.08 ).

More recently, Levi 2010 reported on the risks related to rFVIIa use, by analysis of data held by Novo Nordisk. The authors reported that individuals who received rFVIIa experienced a higher frequency of arterial thromboembolic events when compared to patients who were given placebo $(5.5 \%$ versus $3.2 \%, \mathrm{P}=0.003$ ). This association was more pronounced among older patients over the ages of 65 years (rFVIIa: $9.0 \%$ versus placebo: $3.8 \%, \mathrm{P}=0.003$ ) and 75 years (rFVIIa: $10.8 \%$ versus placebo: $4.1 \%, \mathrm{P}=0.02$ ). In the Levi 2010 study, there was no significant difference in the rates of venous thromboembolism among patients who received rFVIIa as compared to those who received placebo (5.3\% versus $5.7 \%$ ).

\section{How do the conclusions of this update differ from the previous review?}

This review provides the most up to date assessment of the effectiveness and safety of RFVIIa. With the addition of four RCTs, there was a significant increase in the number of arterial thromboembolic events observed among patients who received rFVIIa. Despite the greater number of trials, almost all of the findings in support of and against the use of rFVIIa could be due to chance, indicating ongoing uncertainty about the true effectiveness of rFVIIa in patients without haemophilia. Suggestions of a potential benefit of rFVIIa reside in the findings of decreased blood loss and red cell transfusion requirements and a trend towards a decreased number of patients who required blood transfusion and decreased mortality in the therapeutic setting. However, the findings of decreased blood loss and red cell transfusion in this review were modest and are likely overestimates of the true benefit of rFVIIa. There may be publication bias particularly in the number of patients transfused overestimating the benefit of rFVIIa, which has been found in other reviews (Hsia 2008; Ranucci 2008). Moreover, in direct (and even some indirect) comparisons of dose of rFVIIa, there was no evidence of a dose-response effect.

Any (small) benefits of rFVIIa are likely to be offset by its potential thromboembolic risks. These risks are likely to be underestimated and may be more serious and/or frequent in the real world than in the RCT setting when tight inclusion criteria apply. For many of the patients in the clinical settings of the included studies, a higher risk of thrombosis might be expected, for example, related to immobilisation and stroke. In addition, a history of thrombosis or vaso-occlusive disease was a criterion for exclusion in most of the included studies and active surveillance (e.g. scheduled lower extremity ultrasounds or troponin measurements) for adverse events was reported in only 11 of 29 trials. These greater risks are consistent with the analysis of passive surveillance of reports describing thromboembolic events for the Food and Drug Administration Adverse Reporting System, which indicated that many events following rFVIIa use occurred after unlabelled indications and often resulted in serious morbidity and mortality (O'Connell 2006).

Although a large, adequately powered trial with a strict transfu- 
sion protocol and active surveillance for adverse events could be designed to address with greater precision the effect size for use of rFVIIa, the results of this review perhaps question the need for such a trial. It seems unlikely that a large benefit for the drug exists based on the findings of 29 trials, and for those trials which initially found evidence of benefit, larger follow-up studies have not confirmed these earlier promising results. This has occurred in the setting of cirrhosis with UGIB where potential benefit in a subgroup of high-risk patients (Bosch 2004) was not confirmed in the RCT looking specifically at this high-risk subgroup (Bosch 2008). In the setting of spontaneous intracranial haemorrhage (ICH), the earlier trial showed benefit in a secondary outcome of disability and death (Mayer 2005a), however this was not borne out in the phase III RCT designed with a primary outcome of disability and death (Mayer 2008). The phase III trial in trauma patients (Hauser 2010a; Hauser 2010b) was terminated early due to a low likelihood of reaching a positive outcome, again not confirming potential benefits seen in the earlier trauma trials (Boffard 2005a; Boffard 2005b).

It is difficult to highlight specific gaps or areas where new RCTs are required now. Although there have been retrospective observational studies supporting the use of rFVIIa in refractory bleeding, such as in the setting of cardiac surgery, these studies are limited by the lack of a control group, lack of transfusion protocols and observer bias. Without performing large RCTs, one cannot exclude an effect of rFVIIa, particularly if compared to the use of another haemostatic agent such as tranexamic acid (which has demonstrated a safer risk profile) or fibrinogen concentrate or even more platelet transfusions in the post-cardiac bypass setting. In these situations, the immediate real risk of life-threatening ongoing haemorrhage is being weighed by clinicians against a potential risk of no benefit from rFVIIa or potential thrombotic harm.
These related issues of prescribing behaviour have also been recently summarised by Lipworth 2012 .

In summary, the aim of this review was to update the assessment of the effectiveness and safety of rFVIIa in the management of bleeding in patients without haemophilia. We conclude that the clinical value of rFVIIa as a more general haemostatic drug, both as prophylaxis in high blood loss surgery and as therapy to treat uncontrollable bleeding, remains unproven. In addition, its use is associated with an increased risk of adverse arterial thrombotic events. Based on the available RCT data, there is little evidence of benefit for the use of off-label rFVIIa in patients without haemophilia.

\section{AUTHORS, CONCLUSIONS}

\section{Implications for practice}

Unrestricted, unevaluated administration of rFVIIa outside licensed uses is not justified on the basis of the randomised controlled trials (RCTs) identified and analysed in this review. Administration of rFVIIa outside its current license should be restricted to rigorous research studies and clinical trials, planned to add to existing knowledge in a systematic way.

\section{Implications for research}

The results of ongoing research should be actively monitored and systematically reviewed independently of the pharmaceutical companies with a financial interest in this drug. Any future RCTs should be adequately powered, focusing on clinical outcomes such as mortality, rather than blood loss and transfusion use. Continuing close attention to measurement of adverse, particularly thromboembolic, events is required.

\section{R E F E R E N C E S}

\section{References to studies included in this review}

\section{Boffard 2005a \{published data only\}}

Boffard KD, Riou B, Warren B, Choong PI, Rizoli S, Rossaint R, et al.Recombinant factor VIIa as adjunctive therapy for bleeding control in severely injured trauma patients: two parallel randomized placebo-controlled double blind clinical trials. Journal of Trauma 2005;59(1): $8-15$.

Boffard 2005b \{published data only\}

Boffard KD, Riou B, Warren B, Choong PI, Rizoli S, Rossaint $\mathrm{R}$, et al.Recombinant factor VIIa as adjunctive therapy for bleeding control in severely injured trauma patients: two parallel randomized placebo-controlled double blind clinical trials. Journal of Trauma 2005;59(1): $8-15$.
Bosch 2004 \{published data only\}

Bosch J, Thabut D, Bendtsen F, D'Amico G, Albillos A, Gonzalez Abraldes J, et al.Recombinant factor VIIa for upper gastrointestinal bleeding patients with cirrhosis: a randomized, double-blind trial. Gastroenterology 2004;127 (4):1123-30.

Bosch 2008 \{published data only\} Bosch J, Thabut D, Albillos A, Carbonell N, Spicak J, Massard J, et al.Recombinant factor VIIa for variceal bleeding in patients with advanced cirrhosis: a randomized, controlled trial. Hepatology 2008;47(5):1604-14.

Chuansumrit 2005 \{published data only\} Chuansumrit A, Wangruangsatid S, Lektrakul Y, Chua MN, Zeta Capeding MR, Bech OM, et al.Control of bleeding in children with Dengue hemorrhagic fever using recombinant activated factor VII: a randomized, double-blind, placebo- 
controlled study. Blood Coagulation \& Fibrinolysis 2005;16 (8):549-55.

Diprose 2005 \{published data only\}

* Diprose P, Herbertson M, O'Shaughnessy D, Gill R. A pilot double blind randomized placebo-controlled trial of the use of recombinant factor VIIa (rf VIIa) in high transfusion risk cardiac surgery. European Journal of Anaesthesiology 2005;21(Suppl 33):2-36.

Herbertson M. Recombinant activated factor VII in cardiac surgery. Blood Coagulation \& Fibrinolysis 2004;15(Suppl 1): S31-2.

Ekert 2006 \{published data only\}

Ekert H, Brizard C, Eyers R, Cochrane A, Henning R. Elective administration in infants of low-dose recombinant activated factor VII (rFVIIa) in cardiopulmonary bypass surgery for congenital heart disease does not shorten time to chest closure or reduce blood loss and need for transfusions: a randomized, double-blind, parallel group, placebocontrolled study of rFVIIa and standard haemostatic replacement therapy versus standard haemostatic replacement therapy. Blood Coagulation \& Fibrinolysis 2006; 17(5):389-95.

Essam 2007 \{published data only\}

Essam MA. Prophylactic administration of recombinant activated factor VII in coronary revascularization surgery. Internet Journal of Anesthesiology 2007;13(1):10.

Friederich 2003 \{published data only\} Friederich PW, Geerdink MGF, Keller TT, Messelink EJ, Henny Ch P, Levi M. Novel applications of recombinant factor VIIa: the effect of the administration of recombinant activated factor VII on perioperative blood loss in patients undergoing transabdominal retropubic prostatectomy: the PROSE study. Infusionstherapie und Transfusionsmedizin 2001;28(2):112-3.

Friederich PW, Geerdink MGF, Spataro M, Messelink EJ, Henny Ch P, Buller HR, et al.The effect of the administration of recombinant activated factor VII on perioperative blood loss in patients undergoing transabdominal retropubic prostatectomy: the PROSE study. Blood Coagulation \& Fibrinolysis 2000;11(Suppl 1): S129-32.

* Friederich PW, Keller T, Buller HR, Levi M. Effect of recombinant activated factor VII on perioperative blood loss in patients undergoing retropubic prostatectomy: a double-blind placebo-controlled randomised trial. Lancet 2003;361(9353):201-5.

Gill 2009 \{published data only\}

Gill R, Herbertson M, Vuylsteke A, Olsen P S, von Heymann C, Mythen M, et al.Additional data obtained from author 2009

* Gill R, Herbertson M, Vuylsteke A, Olsen PS, von Heymann C, Mythen M, et al.Safety and efficacy of recombinant activated factor VII: a randomized placebocontrolled trial in the setting of bleeding after cardiac surgery. Circulation 2009;120(1):21-7.
Hanna 2010 \{published data only\}

* Hanna MG, Refaie A, Gouda N, Obaya G. Reduction of peri-operative bleeding in craniofacial surgeries in pediatrics. Comparison between recombinant factor VII and tranexamic acid. Egyptian Journal of Anaesthesia 2010; 26:53-61.

Hauser 2010a \{published data only\}

Hauser C J, Boffard K, Dutton R, Bernard GR, Croce $\mathrm{MA}$, Holcomb JB, et al.Results of the CONTROL trial: efficacy and safety of recombinant activated factor VII in the management of refractory traumatic hemorrhage. Journal of Trauma 2010;69(3):489-500.

Hauser 2010b \{published data only\}

Hauser CJ, Boffard K, Dutton R, Bernard GR, Croce MA, Holcomb JB, et al.Results of the CONTROL trial: efficacy and safety of recombinant activated factor VII in the management of refractory traumatic hemorrhage. Journal of Trauma 2010;69(3):489-500.

\section{Jeffers 2002 \{published data only\}}

Jeffers L, Chalasani N, Balart L, Pyrsopoulos N, Erhardtsen E. Safety and efficacy of recombinant factor VIIa in patients with liver disease undergoing laparoscopic liver biopsy. Gastroenterology 2002;123:118-26.

Johansson 2007 \{published data only\}

Johansson PI, Eriksen K, Nielsen SL, Rojkjaer R, Alsbjorn B. Recombinant FVIIa decreases perioperative blood transfusion requirement in burn patients undergoing excision and skin grafting - results of a single centre pilot study. Burns 2007;33(4):435-40.

Lodge 2005a \{published data only\}

* Lodge JP, Jonas S, Oussoultzoglou E, Malago M, Jayr C, Cherqui $\mathrm{D}$, et al.Recombinant coagulation factor VIIa in major liver resection: a randomized, placebo-controlled, double-blind clinical trial. Anesthesiology 2005;102(2):269. Lodge JPA. Hemostasis in liver resection surgery. Seminars in Hematology 2004;41(Suppl 1):70-5.

Lodge 2005b \{published data only\}

* Lodge JP, Jonas S, Jones RM, Olausson M, Mir-Pallardo J, Soefelt $S$, et al.Efficacy and safety of repeated perioperative doses of recombinant factor VIIa in liver transplantation.

Liver Transplantation 2005;11(8):973-9.

Lodge JPA. Hemostasis in liver resection surgery. Seminars in Hematology 2004;41(Suppl 1):70-5.

\section{Ma 2006 \{published data only\}}

Ma B, Wang ZN, Zhang BR, Xu ZY, Yang LX, Chen KB, et al.Effect of recombinant activated factor VIIa on early recovery of patients undergoing cardiac valve replacement under cardiopulmonary bypass: a randomized double-blind placebo-controlled trial. Academic Journal of Second Military Medical University 2006;27:1110-3.

\section{Mayer 2005a \{published data only\}}

Mayer SA. Intracerebral hemorrhage: natural history and rationale of ultra-early hemostatic therapy. Intensive Care Medicine 2002;28:S235-40.

* Mayer SA, Nikolai MD, Brun C, Begtrup K, Broderick J, Davis $S$, et al.Recombinant activated factor VII for acute 
intracerebral hemorrhage. New England Journal of Medicine 2005;352(8):777-85.

Pickard JD, Kirkpatrick PJ, Melsen T, Andreasen RB, Gelling L, Fryer T, et al.Potential role of NovoSeven in the prevention of rebleeding following aneurysmal subarachnoid haemorrhage. Blood Coagulation \& Fibrinolysis 2000;11 (Suppl 1):S117-20.

Mayer 2005b \{published data only\}

Mayer SA. Intracerebral hemorrhage: natural history and rationale of ultra-early hemostatic therapy. Intensive Care Medicine 2002;28:S235-40.

* Mayer SA, Brun NC, Broderick J, Davis S, Diringer MN, Skolnick BE, et al.Safety and feasibility of recombinant factor VIIa for acute intracerebral hemorrhage. Stroke 2005; 36(1):74-9.

Pickard JD, Kirkpatrick PJ, Melsen T, Andreasen RB, Gelling L, Fryer T, et al.Potential role of NovoSeven in the prevention of rebleeding following aneurysmal subarachnoid haemorrhage. Blood Coagulation \& Fibrinolysis 2000;11 (Suppl 1):S117-20.

Mayer 2006 \{published data only\}

Mayer SA, Brun NC, Broderick J, Davis SM, Diringer MN, Skolnick BE, et al.Recombinant activated factor VII for acute intracerebral hemorrhage: US phase IIA trial. Neurocritical Care 2006;4(3):206-14.

Mayer 2008 \{published data only\}

Mayer SA, Brun NC, Begtrup K, Broderick J, Davis S, Diringer MN, et al.Efficacy and safety of recombinant activated factor VII for acute intracerebral hemorrhage. New England Journal of Medicine 2008;358(20):2127-37.

Narayan 2008 \{published data only\}

Narayan RK, Maas AI, Marshall LF, Servadei F, Skolnick BE, Tillinger MN, rFVIIa Traumatic ICH Study Group. Recombinant factor VIIA in traumatic intracerebral hemorrhage: results of a dose-escalation clinical trial. Neurosurgery 2008;62(4):776-86. [: Clinicaltrials.gov Identifier: NCT00123591]

Pihusch 2005 \{published data only\}

Bacigalupo A. Haemopoietic stem cell transplants: the impact of haemorrhagic complications. Blood Reviews 2003; 17:S6-10.

* Pihusch M, Bacigalupo A, Szer J, von Depka Prondzinski M, Gaspar-Blaudschun B, Hyveled L, et al.Recombinant activated factor VII in treatment of bleeding complications following hematopoietic stem cell transplantation. Journal of Thrombosis \& Haemostasis 2005;3(9):1935-44.

Planinsic 2005 \{published data only\}

* Planinsic RM, Testa G, Grande L, Candela A, van der Meer J, Porte RJ, et al.Safety and efficacy of a single bolus administration of recombinant factor VIIa in liver transplantation due to chronic liver disease. Liver Transplantation 2005;11(8):895-900.

Pugliese 2007 \{published data only\}

Pugliese F, Ruberto F, Summonti D, Perrella S, Cappannoli

A, Tosi A, et al.Activated recombinant factor VII in orthotopic liver transplantation. Transplantation Proceedings 2007;39(6):1883-5.

Raobaikady 2005 \{published data only\}

Raobaikady R, Redman J, Ball JA, Maloney G, Grounds RM. Use of activated recombinant coagulation factor VII in patients undergoing reconstruction surgery for traumatic fracture of pelvis and acetabulum: a double-blind randomized, placebo-controlled trial. British Journal of Anaesthesia 2005;94(5):586-91.

Sachs 2007 \{published data only\} Sachs B, Delacy D, Green J, Graham RS, Ramsay J, Kreisler N, et al.Recombinant activated factor VII in spinal surgery: a multicenter, randomized, double-blind, placebo-controlled, dose-escalation trial. Spine 2007;32 (21):2285-93.

Shao 2006 \{published data only\} Shao YF, Yang JM, Chau GY, Sirivatanauksorn Y, Zhong SX, Erhardtsen E, et al.Safety and hemostatic effect of recombinant activated factor VIIa in cirrhotic patients undergoing partial hepatectomy: a multicenter, randomized, double-blind, placebo-controlled trial. American Journal of Surgery 2006;191(2):245-9.

\section{References to studies excluded from this review}

Ashrani 2006 \{published data only\}

Ashrani AA, Gabriel DA, Gajewski JL, Jacobs DRJ, Weisdorf DJ, Key NS. Pilot study to test the efficacy and safety of activated recombinant factor VII (NovoSeven) in the treatment of refractory hemorrhagic cystitis following high-dose chemotherapy. Bone Marrow Transplantation 2006;38(12):825-8.

Bijsterveld 2002 \{published data only\} Bijsterveld NR, Moons AH, Boekholdt SM, van Aken $\mathrm{BE}$, Fennema $\mathrm{H}$, Peters RJ, et al.Ability of recombinant factor VIIa to reverses the anticoagulant effect of the pentasaccharide fondaparinux in healthy volunteers. Circulation 2002;106(20):2550-4.

Bijsterveld 2004 \{published data only\}

Bijsterveld NR, Vink R, van Arken BE, Fennema H, Peters RJG, Meijers JCM, et al.Recombinant factor VIIa reverses the anticoagulant effect of the long-acting pentasaccharide idraparinux in healthy volunteers. British Journal of Haematology 2004;124(5):653-8.

Boffard 2009 \{published data only\} Boffard KD, Choong PI, Kluger Y, Riou B, Rizoli SB, Rossaint R, et al.NovoSeven Trauma Study Group. The treatment of bleeding is to stop the bleeding! Treatment of trauma-related hemorrhage. Transfusion 2009;49(Suppl 5): $240 s-7 s$.

Bysted 2007 \{published data only\} Bysted BV, Scharling B, Møller T, Hansen BL. A randomized, double-blind trial demonstrating bioequivalence of the current recombinant activated factor VII formulation and a new robust 25 degrees $\mathrm{C}$ stable formulation. Haemophilia 2007;13(5):527-32. 
Davis 2004 \{published data only\}

Davis S, Mayer S, Brun N, Broderick J, Diringer MN, Steiner T. Safety of activated recombinant factor VII in acute intracerebral hemorrhage: results of two multi-center placebo-controlled trials. Internal Medicine Journal 2004; 34:1-2.

Diringer 2007 \{published data only\} Diringer MN, Ferran JM, Broderick JP, Davis S, Mayer SA, Steiner T, et al.Impact of recombinant activated factor VII on health-related quality of life after intracerebral hemorrhage. Cerebrovascular Diseases 2007;23(2-3): $219-25$.

Elgafy 2010 \{published data only\} Elgafy H, Bransford RJ, McGuire RA, Dettori JR, Fischer D. Blood loss in major spine surgery: are there effective measures to decrease massive hemorrhage in major spine fusion surgery?. Spine 2010;35(Suppl 9):S47-56. [PUBMED: 20407351]

Ensor 2011 \{published data only\}

Ensor CR, Paciullo CA, Cahoon WD Jr, Nolan PE Jr. Pharmacotherapy for mechanical circulatory support: a comprehensive review. Annals of Pharmacotherapy 2011;45 (1):60-77. [PUBMED: 21205950]

Fridberg 2005 \{published data only\}

Fridberg MJ, Hedner U, Roberts HR, Erhardtsen E. A study of the pharmacokinetics and safety of recombinant activated factor VII in healthy Caucasian and Japanese subjects. Blood Coagulation and Fibrinolysis 2005;16(4):259-66.

Gurusamy 2009 \{published data only\} Gurusamy KS, Li J, Sharma D, Davidson BR. Pharmacological interventions to decrease blood loss and blood transfusion requirements for liver resection. Cochrane Database of Systematic Reviews 2009, Issue 4. [DOI: 10.1002/14651858.CD008085]

Jilma 2002 \{published data only\}

Jilma B, Marsil C, Mayr F, Graninger MT, Taylor FB, Ribel $\mathrm{MC}$, et al.Pharmacodynamics of active site-inhibited factor VIIa in endotoxin-induced coagulation in humans. Clinical Pharmacology and Therapeutics 2002;72(4):403-10.

Johansson 2010 \{published data only\} Johansson PI, Ostrowski SR. Evidence supporting the use of recombinant activated factor VII in congenital bleeding disorders. Drug Design, Development and Therapy 2010;4: 107-16. [PUBMED: 20689697]

Kolban 2005 \{published data only\} Kolban M, Balachowska KI, Chmielnicki M. The use of recombinant coagulation factor VIIa in patients undergoing surgical correction of scoliosis with the C-D method. Ortopedia Traumatologia Rehabilitacja 2005;7(3):285-9.

Larsen 2010 \{published data only\} Larsen OH, Ezban M, Persson E, Ingerslev J, Sorensen B. Artificial contact pathway activation masks the haemostatic potential of rFVIIa and NN1731 in thrombocytopenic whole blood. British Journal of Haematology 2010;150(1): $124-7$.
Leduc 2009 \{published data only\}

Leduc D, Senikas V, Lalonde AB, Ballerman C, Biringer A, Delaney $\mathrm{M}$, et al.Active management of the third stage of labour: prevention and treatment of postpartum hemorrhage. Journal of Obstetrics and Gynaecology 2009;31 (10):980-93. [PUBMED: 19941729]

Levi 2010 \{published data only\}

Levi M, Levy JH, Andersen HF, Truloff D. Safety of recombinant activated factor VII in randomized clinical trials. New England Journal of Medicine 2010;363(19): 1791-800. [PUBMED: 21047223]

Lin 2011b \{published data only\}

Lin Y, Stanworth S, Birchall J, Doree C, Hyde C. Use of recombinant factor VIIa for the prevention and treatment of bleeding in patients without hemophilia: a systematic review and meta-analysis. Canadian Medical Association Journal 2011;183(1):E9-19. [PUBMED: 21078742]

Logan 2010 \{published data only\}

Logan AC, Goodnough LT. Recombinant factor VIIa: an assessment of evidence regarding its efficacy and safety in the off-label setting. Hematology/the Education Program of the American Society of Hematology. American Society of Hematology. Education Program 2010;2010:153-9. [PUBMED: 21239786]

Macieji 2004 \{published data only\} Macieji K, Ina BK, Slawomir Z, Lukasz K. Use of small doses of recombinant factor VIIa during scoliosis surgery. Journal of Bone and Joint Surgery (Proceedings) 2004;86 B.C. (Suppl 1):94-9a.

Nishijima 2009 \{published data only\}

Nishijima DK, Zehtabchi S. Evidence-based emergency medicine/critically appraised topic. The efficacy of recombinant activated factor VII in severe trauma. Annals of Emergency Medicine 2009;54(5):737-44.e1. [PUBMED: 19285753]

Perel 2010 \{published data only\}

Perel P, Roberts I, Shakur H, Thinkhamrop B, Phuenpathom $\mathrm{N}$, Yutthakasemsunt $S$. Haemostatic drugs for traumatic brain injury. Cochrane Database of Systematic Reviews 2010, Issue 1. [DOI: 10.1002/14651858.CD007877.pub2]

Perez 2007 \{published data only\} Perez AF, Serra C, Macia J, Mayol L. rFVII for pediatric acute intracranial hemorrhage. Stroke 2007;38(7):E63-4.

Plaat 2007 \{published data only\} Plaat F. Recombinant factor VIIa should be used in massive obstetric haemorrhage. International Journal of Obstetric Anesthesia 2007;16(4):354-7.

Pugh 2007 \{published data only\} Pugh R, Wenstone R. Predicting response to recombinant factor VIIa in non-haemophilia patients with severe haemorrhage (1). British Journal of Anaesthesia 2007;98(5): 690.

Strydom 2010 \{published data only\}

Strydom J. The rational use of recombinant factor VIIa in the treatment of major intractable bleeding in the 
trauma patient. Southern African Journal of Anaesthesia and Analgesia 2010;16(1):130-3.

Thabut 2011 \{published data only\}

Thabut D, Rudler M, Rousseau G, Poynard T. Recombinant activated factor VII in chronic liver diseases: should we be afraid of thromboembolic events?. Journal of Hepatology 2011;55(2):483-5. [PUBMED: 21349297]

Van De Velde 2007 \{published data only\}

Van de Velde M. Recombinant factor VIIa should be used in massive obstetric haemorrhage. International Journal of Obstetric Anesthesia 2007;16(4):357-9.

Vincent 2009 \{published data only\}

Vincent JL, Artigas A, Petersen LC, Meyer C. A multicenter, randomized, double-blind, placebo-controlled, doseescalation trial assessing safety and efficacy of active site inactivated recombinant factor VIIa in subjects with acute lung injury or acute respiratory distress syndrome. Critical Care Medicine 2009;37(6):1874-80.

Vink 2004 \{published data only\}

Vink R, Bijsterveld NR, Van Aken BE, Fennema H, Peters RJG, Joost CM, et al.Recombinant factor VIIa reverses the anticoagulant effect of the long-standing anticoagulant idraparinux in healthy volunteers. Blood 2004;102(11): $812 \mathrm{a}$.

Woltz 2004 \{published data only\}

Woltz M, Levi M, Sarich LC, Bostram SL, Eriksson UG, Eriksson-Lepkoska M, et al.Effect of recombinant factor VIIa on melagatran-induced inhibition of thrombin generation and platelet activation in healthy volunteers. Thrombosis and Haemostasis 2004;91(6):1090-6.

Yank 2009 \{published data only\}

Yank V, Logan AC, Tuohy CV, Bravata DM, Staudenmayer $\mathrm{K}$, Eisenhut R, et al.Comparison of thromboembolic event rates in randomized controlled trials and observational studies of recombinant factor VIIa for off-label indications. A meta-analysis. ASH Annual Meeting Abstracts. Blood 2009;114(22).

Yank 2011 \{published data only\}

Yank V, Tuohy CV, Logan AC, Bravata DM, Staudenmayer $\mathrm{K}$, Eisenhut R, et al.Systematic review: benefits and harms of in-hospital use of recombinant factor VIIa for off-label indications. Annals of Internal Medicine 2011;154(8): 529-40.

Yuan 2010 \{published data only\}

Yuan ZH, Jiang JK, Huang WD, Pan J, Zhu JY, Wang JZ. A meta-analysis of the efficacy and safety of recombinant activated factor VII for patients with acute intracerebral hemorrhage without hemophilia. Journal of Clinical Neuroscience 2010;17(6):685-93. [PUBMED: 20399668]

\section{References to ongoing studies}

Arai 2005 \{published and unpublished data\}

Arai M. Factor VIIa: Safety of Eptacog Alfa (activated) (genetical recombination) on adverse events and serious adverse events in patients with acute intracerebral haemorrhage. ClinicalTrials.gov 2005. [: ClinicalTrials.gov Identifier: NCT00266006; : Novo Nordisk Clinical Trial ID: F7ICH-1602]

Flaherty 2008 \{published data only\} Flaherty ML, Jauch EC. The spot sign for predicting and treating intracerebral hemorrhage growth study. Clinicaltrials.gov 2008. [: Clinicaltrials.gov Identifier: NCT00810888]

Gajewski 2005 \{unpublished data only\}

Gajewski JL, Vogelsang G, Key N, Goodnough L. A multi-center, randomized, double-blind, parallel groups, placebo-controlled trial on efficacy and safety of activated recombinant factor VII (rFVIIa/NovoSeven) in the treatment of bleeding in patients following hematopoietic stem cell transplantation (HSCT). Novo Nordisk Clinical Trial ID: F7SCT-1485 2005.

Gladstone 2011 \{published data only\} Gladstone DJ, Aviv RI, Demchuk AM. "Spot sign" selection of intracerebral hemorrhage to guide hemostatic therapy (SPOTLIGHT). ClinicalTrials.gov 2010. [: ClinicalTrials.gov identifier NCT01359202]

Gris 2006 \{published data only\}

Gris JC. rhuFVIIa in post-partum hemorrhage. ClinicalTrials.gov 2006. [: Clinicaltrials.gov Identifier: NCT00370877]

Imberti 2005 \{published and unpublished data\} Imberti R. Efficacy and safety of factor VIIa (Eptacog Alfa) on rebleeding after surgery for spontaneous supratentorial intracerebral hemorrhage. A randomized, controlled, openlabel, investigator-blinded pilot study. ClinicalTrials.gov 2005. [: ClinicalTrials.gov Identifier: NCT00128050]

Iorio 2006 \{published and unpublished data\} Iorio A. Randomized, open, prospective, multicenter pilot study to evaluate the efficacy and safety of activated recombinant factor VII in acute intracerebral haemorrhage in patients treated with oral anticoagulants or antiplatelets agents. ClinicalTrials.gov 2006. [: ClinicalTrials.gov Identifier: NCT00222625]

Kelleher 2006 \{published data only\}

Kelleher A. A multi-centre, randomised, double-blind, placebo-controlled, dose-escalation trial of safety and efficacy of activated recombinant factor VII (Rfv11a/NovoSeven) in the treatment of post-operative bleeding in patients following cardiac surgery requiring cardiopulmonary bypass. http://www2.rbht.nhs.uk/research/projects.

McCall 2005 \{published and unpublished data\} McCall P, Poustie S. "Salvage use" of recombinant activated factor VII after inadequate haemostatic response to conventional therapy in complex cardiac surgery - a randomised placebo-controlled trial. ClinicalTrials.gov 2005. [: ClinicalTrials.gov Identifier: NCT00214656]

Molter 2005 \{published and unpublished data\} Molter NC, Park MS, Frail EA. Effect of recombinant coagulation factor VIIa on peri-operative blood loss in patients undergoing major burn excision and grafting. 
ClinicalTrials.gov 2005. [: ClinicalTrials.gov Identifier: NCT00243243]

Ng 2006 \{published and unpublished data\}

$\mathrm{Ng} \mathrm{C}$. Use of recombinant activated factor seven (FVII) in bleeding ECMO patients post cardiac surgery. Randomised prospective study. National Research Register 2005. [: N0012154243; ISRCTN98382551]

\section{Additional references}

\section{Ahonen 2005}

Ahonen J, Jokela R. Recombinant factor VIIa for lifethreatening post-partum haemorrhage. British Journal of Anaesthesia 2005;94(5):592-5.

\section{Della Corte 2006}

Della Corte F. Efficacy and safety of factor VIIa on rebleeding after surgery for spontaneous intracerebral hemorhage (ICH). Clinical Trials.gov 2006. [: Clinicaltrials.gov Identifier: NCT00128050]

\section{Greisen 2003}

Greisen G, Andreasen RB. Recombinant factor VIIa in preterm neonates with prolonged prothrombin time. Blood Coagulation \& Fibrinolysis 2003;14(1):117-20.

\section{Hedner 2002}

Hedner U, Erhardtsen E. Potential role for rVIIa in transfusion medicine. Transfusion 2002;42(1):114-24.

Higgins 2011

Higgins JPT, Green S (editors). Cochrane Handbook for Systematic Reviews of Interventions 5.1.0 [updated March 2011]. The Cochrane Collaboration, 2011. Available from www.cochrane-handbook.org.

\section{Hsia 2008}

Hsia CC, Chin-Yee IH, McAlister VC. Use of recombinant activated factor VII in patients without hemophilia: a metaanalysis of randomized control trials. Annals of Surgery 2008;248(1):61-8.

Isbister 2008

Isbister J, Phillips L, Dunkley S, Jankelowitz G, McNeil J, Cameron P. Recombinant activated factor VII in critical bleeding: experience from the Australian and New Zealand Haemostasis Register. Internal Medicine Journal 2008;38 (3):156-65.

Key 2003a

Key NS, Mast AE. Factor VIIa and tissue factor pathway inhibitor. In: Stowell C, Dzik W editor(s). Emerging Technologies in Transfusion Medicine. AABB Press, 2003.

Key 2003b

Key NS. Recombinant FVIIa for intractable hemorrhage: more questions than answers. Transfusion 2003;43(12): 1649-51.

Lipworth 2012

Lipworth W, Kerridge I, Little M, Day R. Evidence and desperation in off-label prescribing: recombinant factor VIIa. BMJ 2012;344:d7926.

\section{Logan 2011}

Logan AC, Yank V, Stafford RS. Off-label use of recombinant factor VIIa in U.S. hospitals: analysis of hospital records. Annals of Internal Medicine 2011;154(8): 516-22.

\section{Lusher 1998}

Lusher JM, Roberts HR, Davignon G, Joist JH, Smith H, Shapiro A, et al.A randomized, double-blind comparison of two dosage levels of recombinant factor VIIa in the treatment of joint, muscle and mucocutaneous haemorrhages in persons with haemophilia A and B, with and without inhibitors. rFVIIa Study Group. Haemophilia 1998;4(6):790-8.

\section{Marti-Carvajal 2007}

Martí-Carvajal AJ, Salanti G, Marti-Carvajal PI. Human recombinant activated factor VII for upper gastrointestinal bleeding in patients with liver diseases. Cochrane Database of Systematic Reviews 2007, Issue 1. [DOI: 10.1002/ 14651858.CD004887.pub2]

\section{O'Connell 2006}

O'Connell KA, Wood JJ, Wise RP, Lozier JN, Braun MM. Thromboembolic adverse events after use of recombinant human coagulation factor VIIa. JAMA 2006;295(3):293-8.

\section{Ranucci 2008}

Ranucci M, Isgro G, Soro G, Conti D, De Toffol B. Efficacy and safety of recombinant activated factor VII in major surgical procedures. Archives of Surgery 2008;143(3): 296-304.

\section{RevMan 2008}

The Nordic Cochrane Centre. The Cochrane Collaboration. Review Manager (RevMan). 5.0. Copenhagen: The Nordic Cochrane Centre. The Cochrane Collaboration, 2008.

\section{Roberts 2004}

Roberts HR, Monroe DM, White GC. The use of recombinant factor VIIa in the treatment of bleeding disorders. Blood 2004;104(13):3858-64.

You 2006

You H, Al-Shahi R. Haemostatic drug therapies for acute primary intracerebral haemorrhage. Cochrane Database of Systematic Reviews 2006, Issue 3. [DOI: 10.1002/ 14651858.CD005951.pub2]

\section{References to other published versions of this review}

\section{Lin 2011}

Lin Y, Stanworth S, Birchall J, Doree C, Hyde C. Recombinant factor VIIa for the prevention and treatment of bleeding in patients without haemophilia. Cochrane Database of Systematic Reviews 2011, Issue 2. [DOI: 10.1002/14651858.CD005011.pub3]

\section{Stanworth 2007} Stanworth SJ, Birchall J, Doree CJ, Hyde C. Recombinant factor VIIa for the prevention and treatment of bleeding in patients without haemophilia. Cochrane Database of Systematic Reviews 2007, Issue 2. [DOI: 10.1002/ 14651858.CD005011.pub2] 
* Indicates the major publication for the study

\section{CHARACTERISTICS OF STUDIES}

\section{Characteristics of included studies [ordered by study ID]}

Boffard 2005a

\begin{tabular}{|c|c|}
\hline Methods & Double-blind, placebo-controlled RCT \\
\hline Participants & $\begin{array}{l}\text { Adults } \\
\text { Severely bleeding blunt trauma } \\
\text { Group } 1 \text { blunt }=69 \text { (numbers eligible for analysis) } \\
\text { Group } 2 \text { blunt }=74 \\
\text { Randomised but not given the allocated treatment }=15 \\
\text { All blunt }=158\end{array}$ \\
\hline Interventions & $\begin{array}{l}\text { Group } 1.3 \text { doses of iv rFVIIa. } 200 \mu \mathrm{g} / \mathrm{kg} \text { first dose, after } 8 \text { units of RBC transf } \\
\mu \mathrm{g} / \mathrm{kg} 1 \text { hour after dose } 1 ; 100 \mu \mathrm{g} / \mathrm{kg} 3 \text { hours after dose } 1 \text {. Total dose } 400 \mu \mathrm{g} / \\
\text { Group } 2 \text {. Placebo given at each of the } 3 \text { time points. }\end{array}$ \\
\hline Outcomes & $\begin{array}{l}\text { 1. (Primary) RBCs transfused in } 48 \text { hours after first dose FVIIa/placebo } \\
\text { 2. Other transfused products in first } 48 \text { hours } \\
\text { 3. Mortality (and a composite endpoint of death and critical complications) } \\
\text { 4. Days on ventilator } \\
\text { 5. Days on ICU } \\
\text { 6. Adverse events }\end{array}$ \\
\hline
\end{tabular}

Sources of Support

Study supported by Novo Nordisk. One author from Novo Nordisk. 4 authors received consultancy fees from Novo Nordisk

Notes Important threats to validity noted (see 'Risk of bias' assessment)

\section{Risk of bias}

\begin{tabular}{|c|c|c|}
\hline Bias & Authors' judgement & Support for judgement \\
\hline $\begin{array}{l}\text { Random sequence generation (selection } \\
\text { bias) }\end{array}$ & Unclear risk & No details given \\
\hline Allocation concealment (selection bias) & Unclear risk & No details given \\
\hline $\begin{array}{l}\text { Blinding of participants and personnel } \\
\text { (performance bias) } \\
\text { All outcomes }\end{array}$ & Unclear risk & Stated to be double-blind, but no detail \\
\hline $\begin{array}{l}\text { Blinding of outcome assessment (detection } \\
\text { bias) } \\
\text { All outcomes }\end{array}$ & Unclear risk & Stated to be double-blind, but no detail \\
\hline
\end{tabular}

Recombinant factor VIla for the prevention and treatment of bleeding in patients without haemophilia (Review) 


\begin{tabular}{l|l|l}
$\begin{array}{l}\text { Incomplete outcome data (attrition bias) } \\
\text { All outcomes }\end{array}$ & Unclear risk & Loss to follow-up: 22; 14\% \\
\hline Selective reporting (reporting bias) & High risk & $\begin{array}{l}\text { Emphasis on analysis where patients who died } \\
\text { within } 48 \text { hours were excluded. For number } \\
\text { of patients requiring massive transfusion, data } \\
\text { for all patients at } 48 \text { hours were not presented }\end{array}$ \\
\hline Other bias & Unclear risk & $\begin{array}{l}\text { Lack of clarity about flow of patients and ap- } \\
\text { propriateness of denominators used in anal- } \\
\text { ysis. Equality of distribution of patients be- } \\
\text { tween the 32 contributing study centres. No } \\
\text { transfusion guidelines provided }\end{array}$ \\
\hline Power calculation? & Low risk & Done; target 140 (achieved)
\end{tabular}

\section{Boffard 2005b}

\begin{tabular}{ll}
\hline Methods & Double-blind, placebo-controlled RCT \\
\hline Participants & Adults \\
& Severely bleeding penetrating trauma \\
& Group 1 penetrating $=70$ \\
& Group 2 penetrating $=64$ \\
& Randomised but not given an allocated treatment $=9$ \\
& All penetrating $=143$ \\
\hline
\end{tabular}

Interventions

Group 1.3 doses of iv rFVIIa. $200 \mu \mathrm{g} / \mathrm{kg}$ first dose, after 8 units of RBC transfused; 100 $\mu \mathrm{g} / \mathrm{kg} 1$ hour after dose $1 ; 100 \mu \mathrm{g} / \mathrm{kg} 3$ hours after dose 1 . Total dose $400 \mu \mathrm{g} / \mathrm{kg}$. Group 2. Placebo given at each of the 3 time points.

Outcomes
$\begin{aligned} & \text { 1. (Primary) RBC transfused in } 48 \text { hours after first dose FVIIa/placebo } \\ & \text { 2. Other transfused products in first } 48 \text { hours } \\ & \text { 3. Mortality } \\ & \text { 4. Days on ventilator } \\ & \text { 5. Days on ICU }\end{aligned}$
consultancy fees from Novo Nordisk

Notes Important threats to validity noted (see 'Risk of bias' assessment)

\section{Risk of bias}

\section{Bias}

Authors' judgement

Support for judgement 


\begin{tabular}{|c|c|c|}
\hline $\begin{array}{l}\text { Random sequence generation (selection } \\
\text { bias) }\end{array}$ & Unclear risk & No details given \\
\hline Allocation concealment (selection bias) & Unclear risk & No details given \\
\hline $\begin{array}{l}\text { Blinding of participants and personnel } \\
\text { (performance bias) } \\
\text { All outcomes }\end{array}$ & Unclear risk & Stated to be double-blind, but no detail \\
\hline $\begin{array}{l}\text { Blinding of outcome assessment (detection } \\
\text { bias) } \\
\text { All outcomes }\end{array}$ & Unclear risk & Stated to be double-blind, but no detail \\
\hline $\begin{array}{l}\text { Incomplete outcome data (attrition bias) } \\
\text { All outcomes }\end{array}$ & Low risk & Loss to follow-up: $13 ; 9 \%$ \\
\hline Selective reporting (reporting bias) & High risk & $\begin{array}{l}\text { Emphasis on analysis where patients who died } \\
\text { within } 48 \text { hours were excluded. For number } \\
\text { of patients requiring massive transfusion, data } \\
\text { for all patients at } 48 \text { hours were not presented }\end{array}$ \\
\hline Other bias & Unclear risk & $\begin{array}{l}\text { Lack of clarity about flow of patients and ap- } \\
\text { propriateness of denominators used in anal- } \\
\text { ysis. Equality of distribution of patients be- } \\
\text { tween the } 32 \text { contributing study centres. No } \\
\text { transfusion guidelines provided }\end{array}$ \\
\hline Power calculation? & Low risk & Done; target 140 (achieved) \\
\hline
\end{tabular}

\section{Bosch 2004}

Methods

\begin{tabular}{ll}
\hline Participants & $\begin{array}{l}\text { Adults } \\
\text { Upper gastrointestinal haemorrhage in patients with cirrhosis } \\
\text { Group } 1=121 \\
\text { Group } 2=121 \\
\text { Randomised but not given allocated treatment }=3 \\
\text { All randomised }=245\end{array}$ \\
\hline Interventions & $\begin{array}{l}\text { Group } 1.8 \times 100 \mu \mathrm{g} / \mathrm{kg} \text { doses of iv rFVIIa. Initial dose given at time }=0, \text { which was } \\
\text { within } 6 \text { hours of bleed/admission. Subsequent doses given at } 0,2,4,6,12,18,24,30 \\
\text { hours. Total dose } 800 \mu \mathrm{g} / \mathrm{kg} . \\
\text { Group } 2 . \text { Placebo at same times. }\end{array}$ \\
\hline Outcomes & $\begin{array}{l}\text { 1. (Primary) Control of acute bleeding within } 5 \text { days OR failure to prevent rebleeding } \\
\text { between } 24 \text { hours and } 5 \text { days or death during first } 5 \text { days } \\
\text { 2. Control of acute bleeding independently }\end{array}$
\end{tabular}


Bosch 2004 (Continued)

3. Prevention of rebleeding independently

4. Active bleeding at first endoscopy

5. 5-day mortality

6. 6-week mortality

7. Transfusion requirements

8. Number of emergency and elective procedures performed

9. Length of stay on intensive care or hospital

10. Frequency of adverse events including thromboembolic events

11. Changes in coagulation related parameters

12. Other haematology and biochemical parameters

Sources of Support

Study supported by Novo Nordisk. Trial planning and steering committee contained Novo Nordisk employees. 2 authors from Novo Nordisk

Notes

Minimal threats to validity (see 'Risk of bias' assessment)

\section{Risk of bias}

\begin{tabular}{|c|c|c|}
\hline Bias & Authors' judgement & Support for judgement \\
\hline $\begin{array}{l}\text { Random sequence generation (selection } \\
\text { bias) }\end{array}$ & Low risk & $\begin{array}{l}\text { Computer-generated. Stratified by trial cen- } \\
\text { tre. Central interactive voice response system }\end{array}$ \\
\hline Allocation concealment (selection bias) & Low risk & $\begin{array}{l}\text { Treatment allocation in sealed envelopes dur- } \\
\text { ing study }\end{array}$ \\
\hline $\begin{array}{l}\text { Blinding of participants and personnel } \\
\text { (performance bias) } \\
\text { All outcomes }\end{array}$ & Low risk & $\begin{array}{l}\text { Stated to be double-blind. Indicated placebo } \\
\text { was identical }\end{array}$ \\
\hline $\begin{array}{l}\text { Blinding of outcome assessment (detection } \\
\text { bias) } \\
\text { All outcomes }\end{array}$ & Low risk & Stated to be double-blind \\
\hline $\begin{array}{l}\text { Incomplete outcome data (attrition bias) } \\
\text { All outcomes }\end{array}$ & Low risk & Loss to follow-up: $8 ; 3 \%$ \\
\hline Selective reporting (reporting bias) & Unclear risk & Study protocol not available \\
\hline Other bias & Low risk & - \\
\hline Power calculation? & Low risk & Done; target 240 (achieved) \\
\hline
\end{tabular}


Methods

Participants
Double-blind, placebo-controlled RCT

Adults

Upper gastrointestinal haemorrhage in patients with cirrhosis

Group $1=85$

Group $2=85$

Group $3=86$

Randomised but not given an allocated treatment $=9$

Total randomised $=265$

Interventions

Group 1. First dose $200 \mu \mathrm{g} / \mathrm{kg}$ rFVIIa iv followed by doses of $100 \mu \mathrm{g} / \mathrm{kg}$ at $2,8,14$ and 20 hours after initial dose. Total dose $600 \mu \mathrm{g} / \mathrm{kg}$

Group 2. First dose $200 \mu \mathrm{g} / \mathrm{kg} \mathrm{rFVIIa}$ iv followed by second dose of $100 \mu \mathrm{g} / \mathrm{kg}$ at 2 hours and placebo at 8,14 and 20 hours after initial dose. Total dose $300 \mu \mathrm{g} / \mathrm{kg}$

Group 3. Placebo at same times.

Outcomes

1. (Primary) Treatment failure defined as: failure to control acute bleeding within 24 hours OR failure to prevent rebleeding OR death within 5 days

2. 5-day and 42-day mortality

3. Failure to control 5-day bleeding

4. Failure to control bleeding within 24 hours

5. Failure to prevent rebleeding at 5 days

6. Number of emergency procedures performed within 5 days

7. Transfusion requirements at 24 hours and 5 days

8. Frequency of adverse events up to 42 days

9. Changes in coagulation related parameters

Sources of Support

Study supported by Novo Nordisk. Sponsor designed study, analysed data and assisted in preparation of manuscript

Notes

Minimal threats to validity noted (see 'Risk of bias' assessment)

\section{Risk of bias}

\section{Bias}

bias)
Authors' judgement

\section{Support for judgement}

Randomisation was computer-generated and stratified by centre with equal allocation between groups. Central interactive voice-response system

As above

Allocation concealment (selection bias) Low risk

Stated to be double-blind. Active agent and

Blinding of participants and personnel Low risk (performance bias)

All outcomes placebo were provided as indistinguishable powders for reconstitution 
Bosch 2008 (Continued)

\begin{tabular}{|c|c|c|}
\hline $\begin{array}{l}\text { Blinding of outcome assessment (detection } \\
\text { bias) } \\
\text { All outcomes }\end{array}$ & Low risk & Stated to be double-blind \\
\hline $\begin{array}{l}\text { Incomplete outcome data (attrition bias) } \\
\text { All outcomes }\end{array}$ & Low risk & Loss to follow-up: 9; $3 \%$ \\
\hline Selective reporting (reporting bias) & Low risk & Registered at www.clinicaltrials.gov \\
\hline Other bias & Unclear risk & $\begin{array}{l}\text { Undesired selection bias occurred in several } \\
\text { centres, whereby patients with a better prog- } \\
\text { nosis were over-represented }\end{array}$ \\
\hline Power calculation? & Low risk & Done; target 258 (not achieved) \\
\hline
\end{tabular}

Chuansumrit 2005

\begin{tabular}{|c|c|c|}
\hline Methods & \multicolumn{2}{|c|}{ Double-blind, placebo-controlled RCT } \\
\hline Participants & \multicolumn{2}{|c|}{$\begin{array}{l}\text { Children } \\
\text { Dengue haemorrhagic fever } \\
\text { Group } 1=18 \\
\text { Group } 2=10\end{array}$} \\
\hline Interventions & \multicolumn{2}{|c|}{$\begin{array}{l}\text { Group } 1.1 \text { dose of } 100 \mu \mathrm{g} / \mathrm{kg} \text { of iv rFVIIa. Further dose allowed after } 30 \text { minutes if } \\
\text { bleeding not controlled. Total dose } 100 \text { to } 200 \mu \mathrm{g} / \mathrm{kg} \text {. } \\
\text { Group 2. Placebo given in same manner. }\end{array}$} \\
\hline Outcomes & \multicolumn{2}{|c|}{$\begin{array}{l}\text { 1. Assessment of bleeding control } 0.25,0.5,0.75,1,2,6,12,24 \text { hours after first dose } \\
\text { of allocated treatment } \\
\text { 2. Blood component requirements } \\
\text { 3. Laboratory investigations } \\
\text { No primary outcome defined }\end{array}$} \\
\hline Sources of Support & \multicolumn{2}{|c|}{ Study supported by Novo Nordisk. One author from Novo Nordisk } \\
\hline Notes & \multicolumn{2}{|c|}{ Important threats to validity noted (see 'Risk of bias' assessment) } \\
\hline \multicolumn{3}{|l|}{ Risk of bias } \\
\hline Bias & Authors' judgement & Support for judgement \\
\hline $\begin{array}{l}\text { Random sequence generation (selection } \\
\text { bias) }\end{array}$ & Unclear risk & No details given \\
\hline Allocation concealment (selection bias) & Unclear risk & No details given \\
\hline
\end{tabular}




\section{Chuansumrit 2005 (Continued)}

\begin{tabular}{|c|c|c|}
\hline $\begin{array}{l}\text { Blinding of participants and personnel } \\
\text { (performance bias) } \\
\text { All outcomes }\end{array}$ & Low risk & $\begin{array}{l}\text { Stated to be double-blind. Indicated that } \\
\text { placebo was identical }\end{array}$ \\
\hline $\begin{array}{l}\text { Blinding of outcome assessment (detection } \\
\text { bias) } \\
\text { All outcomes }\end{array}$ & Low risk & Stated to be double-blind \\
\hline $\begin{array}{l}\text { Incomplete outcome data (attrition bias) } \\
\text { All outcomes }\end{array}$ & Unclear risk & Loss to follow-up: $3 ; 11 \%$ \\
\hline Selective reporting (reporting bias) & Unclear risk & Study protocol not available \\
\hline Other bias & Unclear risk & $\begin{array}{l}\text { Small study size. Equality of distribution of } \\
\text { patients between the } 5 \text { contributing study } \\
\text { centres. No specific transfusion guidelines } \\
\text { provided }\end{array}$ \\
\hline Power calculation? & High risk & No power calculation \\
\hline
\end{tabular}

Diprose 2005

Methods

Participants
Adults

Complex non-coronary cardiac surgery requiring cardio-pulmonary bypass

Group $1=10$

Group 2 = 10

Total randomised $=20$

Interventions

Group 1.1 dose of $90 \mu \mathrm{g} / \mathrm{kg}$ rFVIIa iv after bypass and reversal of heparin.

Group 2. Placebo; equivalent volume of $0.9 \%$ saline.

Outcomes

1. (Primary) The number of patients receiving any allogeneic transfusion

2. Total units of red cells and coagulation products transfused

3. Adverse events

4. Also reported length of stay in intensive care and hospital

Sources of Support

2 authors had consulted for Novo Nordisk. The company had no role in design, execution or interpretation of the study

Notes

Important threats to validity noted (see 'Risk of bias' assessment)

\section{Risk of bias}

Bias 


\section{Diprose 2005 (Continued)}

\begin{tabular}{l|l|l}
$\begin{array}{l}\text { Random sequence generation (selection } \\
\text { bias) }\end{array}$ & Low risk & Computer-generated random numbers \\
\hline Allocation concealment (selection bias) & Unclear risk & No details given \\
\hline $\begin{array}{l}\text { Blinding of participants and personnel } \\
\text { (performance bias) } \\
\text { All outcomes }\end{array}$ & Low risk & $\begin{array}{l}\text { Stated to be double-blind (investigators, pa- } \\
\text { tients, and all involved in patient care). All } \\
\text { study agents identified, prepared and blinded } \\
\text { by pharmacy staff. Placebo was equal volume } \\
\text { of saline }\end{array}$ \\
\hline
\end{tabular}

Blinding of outcome assessment (detection Low risk

Stated to be double-blind (investigators, pabias) tients and all involved in patient care)

All outcomes

\begin{tabular}{l|ll}
\hline $\begin{array}{l}\text { Incomplete outcome data (attrition bias) } \\
\text { All outcomes }\end{array}$ & Low risk & Loss to follow-up: 0; 0\% \\
\hline Selective reporting (reporting bias) & Unclear risk & Study protocol not available \\
\hline Other bias & High risk & $\begin{array}{l}\text { Difference in baseline characteristics. Small } \\
\text { study which was underpowered }\end{array}$ \\
\hline Power calculation? & Low risk & Done; target 64 (not achieved) \\
\hline
\end{tabular}

Ekert 2006

\begin{tabular}{|c|c|}
\hline Methods & Double-blind, placebo-controlled RCT \\
\hline Participants & $\begin{array}{l}\text { Infants less than } 1 \text { year of age } \\
\text { Congenital heart disease requiring cardio-pulmonary bypass } \\
\text { Group } 1=40 \\
\text { Group } 2=36 \\
\text { Randomised but not given an allocated treatment }=6 \\
\text { Total randomised }=82\end{array}$ \\
\hline Interventions & $\begin{array}{l}\text { Group 1. First dose of } 40 \mu \mathrm{g} / \mathrm{kg} \text { rFVIIa iv after bypass and reversal of heparin; second } \\
\text { dose if excessive bleeding at } 20 \text { minutes post-reversal of heparin; third dose if delayed } \\
\text { postoperative bleeding in the post-surgery recovery period. All participants had } 1 \text { or } 2 \\
\text { doses. Total dose } 40 \text { to } 80 \mu \mathrm{g} / \mathrm{kg} \\
\text { Group 2. Placebo, freeze-dried powder for reconstitution, as for group } 1\end{array}$ \\
\hline Outcomes & $\begin{array}{l}\text { 1. (Primary) Time to chest closure after reversal of heparin } \\
\text { 2. Units/volume of platelets, FFP and blood transfused in the first } 48 \text { to } 72 \text { hours } \\
\text { 3. Blood loss in the first } 12 \text { hours }\end{array}$ \\
\hline Sources of Support & Novo Nordisk supplied study agent and placebo but no other stated involvement \\
\hline
\end{tabular}


Ekert 2006 (Continued)

\begin{tabular}{|c|c|c|}
\hline Notes & \multicolumn{2}{|c|}{ Some threats to validity noted (see 'Risk of bias' assessment) } \\
\hline \multicolumn{3}{|l|}{ Risk of bias } \\
\hline Bias & Authors' judgement & Support for judgement \\
\hline $\begin{array}{l}\text { Random sequence generation (selection } \\
\text { bias) }\end{array}$ & Unclear risk & No details given \\
\hline Allocation concealment (selection bias) & Unclear risk & No details given \\
\hline $\begin{array}{l}\text { Blinding of participants and personnel } \\
\text { (performance bias) } \\
\text { All outcomes }\end{array}$ & Low risk & $\begin{array}{l}\text { Stated to be double-blind. Indicated that } \\
\text { placebo identical. For primary outcome, op- } \\
\text { erating team was unaware of results of pro- } \\
\text { thrombin time until patient in intensive care } \\
\text { unit after chest closure }\end{array}$ \\
\hline $\begin{array}{l}\text { Blinding of outcome assessment (detection } \\
\text { bias) } \\
\text { All outcomes }\end{array}$ & Low risk & Stated to be double-blind \\
\hline $\begin{array}{l}\text { Incomplete outcome data (attrition bias) } \\
\text { All outcomes }\end{array}$ & Low risk & Loss to follow-up: $1 ; 1 \%$ \\
\hline Selective reporting (reporting bias) & Unclear risk & Study protocol not available \\
\hline Other bias & Low risk & - \\
\hline Power calculation? & High risk & No power calculation \\
\hline
\end{tabular}

Essam 2007

\begin{tabular}{ll}
\hline Methods & RCT \\
\hline Participants & $\begin{array}{l}\text { Adults } \\
\text { Elective cardiac revascularisation requiring cardio-pulmonary bypass } \\
\text { Group } 1=15 \\
\text { Group } 2=15 \\
\text { Total randomised }=30\end{array}$ \\
\hline Interventions & $\begin{array}{l}\text { Group } 1.1 \text { dose of } 90 \mu \mathrm{g} / \mathrm{kg} \text { rFVIIa iv after bypass and reversal of heparin. Group 2. No } \\
\text { rFVIIa }\end{array}$ \\
\hline Outcomes & $\begin{array}{l}\text { 1. Chest tube drainage during first } 24 \text { hours after surgery } \\
\text { 2. Blood products transfused during first } 24 \text { hours after surgery } \\
\text { 3. Serial haematological parameters during first } 24 \text { hours after surgery including haemo- } \\
\text { globin, INR, PTT, fibrinogen }\end{array}$ \\
\hline
\end{tabular}


Essam 2007 (Continued)

\begin{tabular}{|c|c|c|}
\hline Sources of Support & \multicolumn{2}{|l|}{ No statement made } \\
\hline Notes & \multicolumn{2}{|c|}{ Important threats to validity noted (see 'Risk of bias' assessment) } \\
\hline \multicolumn{3}{|l|}{ Risk of bias } \\
\hline Bias & Authors' judgement & Support for judgement \\
\hline $\begin{array}{l}\text { Random sequence generation (selection } \\
\text { bias) }\end{array}$ & Unclear risk & No details given \\
\hline Allocation concealment (selection bias) & Unclear risk & Randomisation was established through sealed envelopes \\
\hline $\begin{array}{l}\text { Blinding of participants and personnel } \\
\text { (performance bias) } \\
\text { All outcomes }\end{array}$ & Unclear risk & $\begin{array}{l}\text { No details given on whether a placebo was given or on outcome } \\
\text { assessment }\end{array}$ \\
\hline $\begin{array}{l}\text { Blinding of outcome assessment (detection } \\
\text { bias) } \\
\text { All outcomes }\end{array}$ & Unclear risk & $\begin{array}{l}\text { No details given on whether a placebo was given or on outcome } \\
\text { assessment }\end{array}$ \\
\hline $\begin{array}{l}\text { Incomplete outcome data (attrition bias) } \\
\text { All outcomes }\end{array}$ & Low risk & Loss to follow-up: $0 ; 0 \%$ \\
\hline Selective reporting (reporting bias) & Unclear risk & Study protocol not available \\
\hline Other bias & Unclear risk & Conclusion overstated for small study size \\
\hline Power calculation? & High risk & No power calculation \\
\hline
\end{tabular}

Friederich 2003

\begin{tabular}{ll}
\hline Methods & Double-blind, placebo-controlled RCT \\
\hline Participants & $\begin{array}{l}\text { Adults } \\
\text { Retropubic prostatectomy } \\
\text { Group } 1=8 \\
\text { Group } 2=16 \\
\text { Group } 3=12 \\
\text { Total randomised }=36\end{array}$ \\
\hline Interventions & $\begin{array}{l}\text { Group } 1.1 \text { dose of } 20 \mu \mathrm{g} / \mathrm{kg} \text { rFVIIa iv in early operative phase. } \\
\text { Group } 2.1 \text { dose of } 40 \mu \mathrm{g} / \mathrm{kg} \mathrm{rFVII} \text { iv at same time. } \\
\text { Group } 3 . \text { Placebo, saline, at same time. }\end{array}$ \\
\hline Outcomes & $\begin{array}{l}\text { 1. (Primary) Total of pre-operative blood loss up to } 24 \text { hours after surgery } \\
\text { 2. (Co-primary) Transfusion requirements } \\
\text { 3. Adverse effects, including thromboembolic events }\end{array}$ \\
\hline
\end{tabular}

Recombinant factor VIla for the prevention and treatment of bleeding in patients without haemophilia (Review)

Copyright @ 2012 The Cochrane Collaboration. Published by John Wiley \& Sons, Ltd. 
Friederich 2003 (Continued)

4. Duration of operation and length of hospital stay were also reported

\begin{tabular}{l|l} 
Sources of Support & Novo Nordisk supplied study agent and placebo but no other stated involvement \\
\hline Notes & Some threats to validity noted (see 'Risk of bias' assessment) \\
\hline
\end{tabular}

\section{Risk of bias}

\begin{tabular}{|c|c|c|}
\hline Bias & Authors' judgement & Support for judgement \\
\hline $\begin{array}{l}\text { Random sequence generation (selection } \\
\text { bias) }\end{array}$ & Low risk & $\begin{array}{l}\text { Randomisation by a computer-generated } \\
\text { scheme }\end{array}$ \\
\hline Allocation concealment (selection bias) & Low risk & $\begin{array}{l}\text { Statement that treatment allocation con- } \\
\text { cealed }\end{array}$ \\
\hline $\begin{array}{l}\text { Blinding of participants and personnel } \\
\text { (performance bias) } \\
\text { All outcomes }\end{array}$ & Low risk & $\begin{array}{l}\text { Stated to be double-blind. Active agent and } \\
\text { placebo (saline) were provided as indistin- } \\
\text { guishable solutions }\end{array}$ \\
\hline $\begin{array}{l}\text { Blinding of outcome assessment (detection } \\
\text { bias) } \\
\text { All outcomes }\end{array}$ & Low risk & Stated to be double-blind \\
\hline $\begin{array}{l}\text { Incomplete outcome data (attrition bias) } \\
\text { All outcomes }\end{array}$ & Low risk & Loss to follow-up: $0 ; 0 \%$ \\
\hline Selective reporting (reporting bias) & Unclear risk & Study protocol not available \\
\hline Other bias & Unclear risk & Small study size \\
\hline Power calculation? & Unclear risk & Done; target not stated \\
\hline
\end{tabular}

Gill 2009

Methods

Participants
Multicentre, double-blind, placebo-controlled RCT

Adult patients undergoing cardiac surgery requiring $\mathrm{CPB}$ and admitted to a postoperative care environment for at least 30 minutes - randomised on reaching prespecified bleeding rate

Group $1=35$

Group $2=69$

Group $3=68$

Randomised but not given the allocated treatment $=7$

Total randomised $=179$ 
Gill 2009 (Continued)

\begin{tabular}{ll}
\hline Interventions & $\begin{array}{l}\text { Group } 1=\mathrm{rFVIIa} 40 \mu \mathrm{g} / \mathrm{kg} \\
\text { Group } 2=\mathrm{rFVII} 80 \mu \mathrm{g} / \mathrm{kg} \\
\text { Group } 3=\text { Placebo }\end{array}$ \\
\hline Outcomes & $\begin{array}{l}\text { 1. (Primary) Critical serious adverse events (death, cerebral infarction, myocardial in- } \\
\text { farction, pulmonary embolism and other thromboembolic events) } \\
\text { 2. Rates of reoperation within } 30 \text { days after rebleeding } \\
\text { 3. Transfusion of allogeneic blood and blood products within } 5 \text { days after trial drug } \\
\text { administration } \\
\text { 4. Drainage volumes from cardiothoracic cavity within } 4 \text { hours, } 24 \text { hours and } 5 \text { days } \\
\text { after trial drug administration }\end{array}$ \\
\hline Sources of Support & $\begin{array}{l}\text { 2 authors from Novo Nordisk } \\
\text { Sponsor responsible for trial operations and statistical analyses }\end{array}$ \\
\hline Notes & Protocol for the use of antifibrinolytics was unclear \\
\hline
\end{tabular}

Risk of bias

\begin{tabular}{l|ll}
\hline Bias & Authors' judgement & Support for judgement \\
\hline $\begin{array}{l}\text { Random sequence generation (selection } \\
\text { bias) }\end{array}$ & Low risk & $\begin{array}{l}\text { Randomised through interactive voice re- } \\
\text { sponse system and were always assigned to } \\
\text { the lowest available randomisation number }\end{array}$ \\
\hline Allocation concealment (selection bias) & Low risk & $\begin{array}{l}\text { Masking of treatment allocation main- } \\
\text { tained until all patient data entered and } \\
\text { database locked }\end{array}$ \\
\hline
\end{tabular}

Blinding of participants and personnel Low risk (performance bias)

Physical appearances of placebo and rFVIIa All outcomes

Blinding of outcome assessment (detection Low risk bias)

All outcomes were identical

\begin{tabular}{|c|c|c|}
\hline $\begin{array}{l}\text { Incomplete outcome data (attrition bias) } \\
\text { All outcomes }\end{array}$ & Low risk & No patients were lost to follow-up \\
\hline Selective reporting (reporting bias) & Unclear risk & Study protocol not available \\
\hline Other bias & Unclear risk & $\begin{array}{l}\text { No protocol provided for the use of antifib- } \\
\text { rinolytic therapy }\end{array}$ \\
\hline Power calculation? & Low risk & $\begin{array}{l}\text { Based on both safety (based on probability } \\
\text { that uneven distribution of critical serious } \\
\text { adverse events between rFVIIa and placebo }\end{array}$ \\
\hline
\end{tabular}


groups would be minimised) and efficacy evaluation to detect a $35 \%$ reduction in need for any allogeneic transfusions on the highest cohort

Hanna 2010

Methods

Participants
Single-centre, placebo-controlled RCT

Paediatric patients of ASA class I and II with congenital craniofacial malformation scheduled to undergo reconstructive surgery

Group $1=15$

Group $2=15$

Group $3=15$

Total randomised $=45$
Group 1 = Control. No medications.

Group 1 = Tranexamic acid at hour 0 , tranexamic acid $100 \mathrm{mg} / \mathrm{kg}$ over 15 minutes and then maintenance infusion of $1 \mathrm{mg} / \mathrm{kg} / \mathrm{h}$ until skin closure

Group $3=\mathrm{rFVIIa}$ at hour 0 , rFVIIa $10 \mu \mathrm{g} / \mathrm{kg}$ over 15 minutes and then maintenance infusion of $10 \mu \mathrm{g} / \mathrm{kg} / \mathrm{h}$ until skin closure
1. Perioperative and intraoperative blood loss

2. Transfusion requirements at $24 \mathrm{~h}$ and 48 hours from treatment

3. Serial measurements for platelet count, fibrinogen concentration and FDPs prior to surgery (hour 0 ), 1 hour and 12 hours following completion of surgery

4. Serial haemoglobin levels were measured hourly

\section{Sources of Support}

Notes
No statement made

Some threats to validity were identified (See 'Risk of bias' assessment)

\section{Risk of bias}

\begin{tabular}{|c|c|c|}
\hline Bias & Authors' judgement & Support for judgement \\
\hline $\begin{array}{l}\text { Random sequence generation (selection } \\
\text { bias) }\end{array}$ & Unclear risk & No details given \\
\hline Allocation concealment (selection bias) & Unclear risk & $\begin{array}{l}\text { Study described as "double-blind", and the } \\
\text { control arm as "placebo". Each patient re- } \\
\text { ceived a small bag with } 2 \text { syringes - for initial } \\
\text { dose and maintenance dose. No details pro- } \\
\text { vided about whether the formulations looked } \\
\text { the same or if the clinical team was blinded }\end{array}$ \\
\hline
\end{tabular}

Blinding of participants and personnel Unclear risk

No details given (performance bias) 
Hanna 2010 (Continued)

\begin{tabular}{l|l|l}
\hline All outcomes & & No details given \\
\hline $\begin{array}{l}\text { Blinding of outcome assessment (detection } \\
\text { bias) } \\
\text { All outcomes }\end{array}$ & Unclear risk & No details given \\
\hline $\begin{array}{l}\text { Incomplete outcome data (attrition bias) } \\
\text { All outcomes }\end{array}$ & Unclear risk & Study protocol not available \\
\hline Selective reporting (reporting bias) & Unclear risk & Small sample size \\
\hline Other bias & Unclear risk & No details were provided \\
\hline Power calculation? & Unclear risk &
\end{tabular}

\section{Hauser 2010a}

\begin{tabular}{ll} 
Methods & Multi-centre, double-blind, placebo-controlled RCT \\
\hline Participants & $\begin{array}{l}\text { Adult patients who had sustained blunt trauma and who had received a minimum of } 4 \\
\text { units of red blood cells (RBCs) but had not yet completed an } 8 \text { th unit within } 12 \text { hours } \\
\text { of injury } \\
\text { Group } 1=221 \\
\text { Group } 2=247 \\
\text { Randomised but not given the allocated treatment }=13 \\
\text { Total randomised }=481\end{array}$ \\
\hline
\end{tabular}

Interventions

Group 1.3 doses of iv rFVIIa. $200 \mu \mathrm{g} / \mathrm{kg}$ first dose, after 8 units of RBC transfused; 100 $\mu \mathrm{g} / \mathrm{kg} 1$ hour after dose $1 ; 100 \mu \mathrm{g} / \mathrm{kg} 3$ hours after dose 1 . Total dose $400 \mu \mathrm{g} / \mathrm{kg}$. Group 2. Placebo given at each of the 3 time points.

Outcomes

Primary:

1. $1^{\text {st }}$ tier endpoint was superiority in all-cause 30 -day mortality in blunt trauma

2. If not met, the $2^{\text {nd }}$ tier primary conditional endpoint of non-inferiority of mortality and superiority on durable morbidity (pulmonary and/or renal dysfunction at day 30) was applied

Secondary:

3. Transfused units of RBC, plasma, platelets, cryoprecipitate, fibrinogen concentrate and all allogeneic blood products at 24 hours and 48 hours after dosing and number of patients requiring massive $\mathrm{RBC}$ transfusion ( $\geq 10$ units of $\mathrm{RBC}$ ) at 24 hours

4. Number of patients with thromboembolic events, multiple organ failure (MOF), single organ failure (SOF) and days alive and free from MOF, SOF, intensive care unit, hospital or ventilator, and/or renal replacement therapy, through day 30

Sources of Support

Drug supplied by sponsor: Novo Nordisk

Sponsor responsible for data management, assisted with trial design

Analyses performed by sponsor but also repeated by independent statistician and the latter is presented in the article 
Hauser 2010a (Continued) $\begin{array}{ll}\text { Notes } & \begin{array}{l}\text { Inaccurate denominators were used although intention-to-treat analysis was supposed } \\ \text { to have been performed }\end{array}\end{array}$

\section{Risk of bias}

\begin{tabular}{|c|c|c|}
\hline Bias & Authors' judgement & Support for judgement \\
\hline $\begin{array}{l}\text { Random sequence generation (selection } \\
\text { bias) }\end{array}$ & Low risk & $\begin{array}{l}\text { Randomisation in random permuted } \\
\text { blocks with allocation of every randomisa- } \\
\text { tion block to a specific centre. Randomisa- } \\
\text { tion was confirmed through an interactive } \\
\text { voice response system set up by the sponsor }\end{array}$ \\
\hline Allocation concealment (selection bias) & Low risk & As above \\
\hline $\begin{array}{l}\text { Blinding of participants and personnel } \\
\text { (performance bias) } \\
\text { All outcomes }\end{array}$ & Low risk & $\begin{array}{l}\text { Description of placebo as the same formu- } \\
\text { lation }\end{array}$ \\
\hline $\begin{array}{l}\text { Blinding of outcome assessment (detection } \\
\text { bias) } \\
\text { All outcomes }\end{array}$ & Unclear risk & $\begin{array}{l}\text { FFP differences may have been due to } \\
\text { changes in INR, the results of which would } \\
\text { have been available to clinicians and the } \\
\text { transfusion protocol was based on INR re- } \\
\text { sults }\end{array}$ \\
\hline $\begin{array}{l}\text { Incomplete outcome data (attrition bias) } \\
\text { All outcomes }\end{array}$ & Low risk & Intention-to-treat analysis was performed \\
\hline Selective reporting (reporting bias) & Unclear risk & Study protocol was not available \\
\hline Other bias & Unclear risk & $\begin{array}{l}\text { Study was terminated early due to futility } \\
\text { analysis }\end{array}$ \\
\hline Power calculation? & Low risk & $\begin{array}{l}\text { Aim was to detect a } 16.7 \% \text { mortality re- } \\
\text { duction with rFVIIa, assuming } 30 \% \text { mor- } \\
\text { tality in placebo patients }\end{array}$ \\
\hline
\end{tabular}

\section{Hauser 2010b}

Methods

Participants
Multi-centre, double-blind, placebo-controlled RCT

Adult patients who had sustained penetrating trauma and who had received a minimum of 4 units of red blood cells (RBCs) but had not yet completed an 8th unit within 12 hours of injury

Group $1=46$

Group $2=40$

Randomised but not given the allocated treatment $=6$

Total randomised $=92$ 
Hauser 2010b (Continued)

\begin{tabular}{ll} 
Interventions & $\begin{array}{l}\text { Group } 1.3 \text { doses of iv rFVIIa. } 200 \mu \mathrm{g} / \mathrm{kg} \text { first dose, after } 8 \text { units of RBC transfused; } 100 \\
\mu \mathrm{g} / \mathrm{kg} 1 \text { hour after dose } 1 ; 100 \mu \mathrm{g} / \mathrm{kg} 3 \text { hours after dose } 1 . \text { Total dose } 400 \mu \mathrm{gg} / \mathrm{kg} . \\
\text { Group } 2 . \text { Placebo given at each of the } 3 \text { time points. }\end{array}$ \\
\hline Outcomes & $\begin{array}{l}\text { Primary: } \\
1.1^{\text {st }} \text { tier endpoint was superiority in all-cause } 30 \text {-day mortality in blunt trauma }\end{array}$ \\
& $\begin{array}{l}\text { 2. If not met, the } 2^{\text {nd }} \text { tier primary conditional endpoint of non-inferiority of mortality } \\
\text { and superiority on durable morbidity (pulmonary and/or renal dysfunction at day } 30)\end{array}$ \\
& was applied \\
& Secondary: \\
& 3. Transfused units of RBC, plasma, platelets, cryoprecipitate, fibrinogen concentrate \\
and all allogeneic blood products at 24 hours and 48 hours after dosing and number of \\
patients requiring massive RBC transfusion ( $\geq 10$ units of RBC) at 24 hours \\
4. Number of patients with thromboembolic events, multiple organ failure (MOF), \\
single organ failure (SOF) and days alive and free from MOF, SOF, intensive care unit, \\
hospital or ventilator, and/or renal replacement therapy, through day 30
\end{tabular}

Sources of Support

Drug supplied by sponsor: Novo Nordisk

Sponsor responsible for data management, assisted with trial design

Analyses performed by sponsor but also repeated by independent statistician and the

latter is presented in the article

Notes

Inaccurate denominators were used although intention-to-treat analysis was supposed

to have been performed

\section{Risk of bias}

\begin{tabular}{|c|c|c|}
\hline Bias & Authors' judgement & Support for judgement \\
\hline $\begin{array}{l}\text { Random sequence generation (selection } \\
\text { bias) }\end{array}$ & Low risk & $\begin{array}{l}\text { Randomisation in random permuted } \\
\text { blocks with allocation of every randomisa- } \\
\text { tion block to a specific centre. Randomisa- } \\
\text { tion was confirmed through an interactive } \\
\text { voice response system set up by the Spon- } \\
\text { sor }\end{array}$ \\
\hline Allocation concealment (selection bias) & Low risk & As above \\
\hline $\begin{array}{l}\text { Blinding of participants and personnel } \\
\text { (performance bias) } \\
\text { All outcomes }\end{array}$ & Low risk & $\begin{array}{l}\text { Description of placebo as the same formu- } \\
\text { lation }\end{array}$ \\
\hline $\begin{array}{l}\text { Blinding of outcome assessment (detection } \\
\text { bias) } \\
\text { All outcomes }\end{array}$ & Unclear risk & $\begin{array}{l}\text { FFP differences may have been due to } \\
\text { changes in INR, the results of which would } \\
\text { have been available to clinicians and the } \\
\text { transfusion protocol was based on INR re- } \\
\text { sults. }\end{array}$ \\
\hline
\end{tabular}

Recombinant factor VIla for the prevention and treatment of bleeding in patients without haemophilia (Review) 
Hauser 2010b (Continued)

\begin{tabular}{l|l|l}
\hline $\begin{array}{l}\text { Incomplete outcome data (attrition bias) } \\
\text { All outcomes }\end{array}$ & Low risk & Intention-to-treat analysis was performed \\
\hline Selective reporting (reporting bias) & Unclear risk & Study protocol was not available \\
\hline Other bias & Unclear risk & $\begin{array}{l}\text { Study was terminated early due to futility } \\
\text { analysis }\end{array}$ \\
\hline Power calculation? & Low risk & Aim was to detect a 16.7\% mortality re- \\
duction with rFVIIa, assuming 30\% mor- \\
tality in placebo patients
\end{tabular}

\section{Jeffers 2002}

\begin{tabular}{|c|c|}
\hline Methods & Double-blind RCT \\
\hline Participants & $\begin{array}{l}\text { Adults } \\
\text { Cirrhosis and coagulopathy undergoing laparoscopic liver biopsy } \\
\text { Group } 1=16 \\
\text { Group } 2=14 \\
\text { Group } 3=17 \\
\text { Group } 4=19 \\
\text { Total randomised = } 66\end{array}$ \\
\hline Interventions & $\begin{array}{l}\text { Group } 1.1 \text { dose of } 5 \mu \mathrm{g} / \mathrm{kg} \text { rFVIIa iv } 10 \text { minutes before biopsy. } \\
\text { Group 2. } 1 \text { dose of } 20 \mu \mathrm{g} / \mathrm{kg} \text { rFVIIa iv at same time pre-biopsy. } \\
\text { Group 3. } 1 \text { dose of } 80 \mu \mathrm{g} / \mathrm{kg} \text { rFVIIa iv at same time. } \\
\text { Group } 4.1 \text { dose of } 120 \mu \mathrm{g} / \mathrm{kg} \text { rFVIIa iv at same time. }\end{array}$ \\
\hline Outcomes & $\begin{array}{l}\text { 1. Time to haemostasis assessed visually } \\
\text { 2. Duration of normal PT } \\
\text { 3. Serial laboratory parameters after rFVIIa infusion including PTT, fibrinogen, D- } \\
\text { dimer, F1+2 and platelets }\end{array}$ \\
\hline Sources of Support & One author from Novo Nordisk \\
\hline Notes & Some threats to validity noted (see 'Risk of bias' assessment) \\
\hline
\end{tabular}

\section{Risk of bias}

\begin{tabular}{l|l|l}
\hline Bias & Authors' judgement & Support for judgement \\
\hline $\begin{array}{l}\text { Random sequence generation (selection } \\
\text { bias) }\end{array}$ & Low risk & $\begin{array}{l}\text { Randomisation in blocks of } 8 \text { and sequentially assigned to } 1 \text { of } \\
4 \text { treatment groups. No details of sequence generation given }\end{array}$ \\
\hline Allocation concealment (selection bias) & Unclear risk & No details given
\end{tabular}


Jeffers 2002 (Continued)

\begin{tabular}{l|l|l}
\hline $\begin{array}{l}\text { Blinding of participants and personnel } \\
\text { (performance bias) } \\
\text { All outcomes }\end{array}$ & Low risk & $\begin{array}{l}\text { Stated to be double-blind. Injection volume per kg body weight } \\
\text { was the same regardless of rFVIIa dose administered }\end{array}$ \\
\hline $\begin{array}{l}\text { Blinding of outcome assessment (detection } \\
\text { bias) } \\
\text { All outcomes }\end{array}$ & Low risk & Stated to be double-blind \\
\hline $\begin{array}{l}\text { Incomplete outcome data (attrition bias) } \\
\text { All outcomes }\end{array}$ & Low risk & Loss to follow-up: 4; 6\% \\
\hline $\begin{array}{l}\text { Selective reporting (reporting bias) } \\
\text { Other bias }\end{array}$ & Unclear risk & Study protocol not available \\
\hline \begin{tabular}{l} 
Power calculation? \\
\hline
\end{tabular} & Unclear risk & No placebo group. No transfusion guidelines provided. \\
\hline
\end{tabular}

\section{Johansson 2007}

\begin{tabular}{|c|c|}
\hline Methods & Double-blind, placebo-controlled RCT \\
\hline Participants & $\begin{array}{l}\text { Adults } \\
\text { Thermal burn undergoing skin excision and grafting } \\
\text { Group } 1=9 \\
\text { Group } 2=9 \\
\text { Total randomised = } 18\end{array}$ \\
\hline Interventions & $\begin{array}{l}\text { Group } 1 \text {. First dose of } 40 \mu \mathrm{g} / \mathrm{kg} \mathrm{rFVIIa} \text { iv given immediately before start of surgery; 2nd } \\
\text { dose given at } 90 \text { minutes later. Total dose } 80 \mu \mathrm{g} / \mathrm{kg} \text {. } \\
\text { Group 2. Placebo as for Group } 1 .\end{array}$ \\
\hline Outcomes & $\begin{array}{l}\text { 1. (Primary) Total number of units of blood components transfused per patient and } \\
\text { percentage full-thickness wound excised during and up to } 24 \text { hours after surgery } \\
\text { 2. Operating time } \\
\text { 3. Number of patients with microvascular bleeding } \\
\text { 4. Percentage graft survival on day } 7 \text { after surgery } \\
\text { 5. Days spent in intensive care unit after surgery } \\
\text { 6. Days of hospitalisation } \\
\text { 7. 30-day mortality } \\
\text { 8. Postoperative complications } \\
\text { 9. Serial laboratory parameters after surgery including PT-INR, FVII activity, thrombin- } \\
\text { antithrombin complexes, tissue factor and IL-6 }\end{array}$ \\
\hline
\end{tabular}

Study supported by an unrestricted educational grant from Novo Nordisk and an employee from Novo Nordisk assisted in preparation of the manuscript 
Johansson 2007 (Continued)

\section{Risk of bias}

\begin{tabular}{|c|c|c|}
\hline Bias & Authors' judgement & Support for judgement \\
\hline $\begin{array}{l}\text { Random sequence generation (selection } \\
\text { bias) }\end{array}$ & Low risk & $\begin{array}{l}\text { Randomised using permuted blocks that were } \\
\text { derived from random number tables }\end{array}$ \\
\hline Allocation concealment (selection bias) & Unclear risk & No details given \\
\hline $\begin{array}{l}\text { Blinding of participants and personnel } \\
\text { (performance bias) } \\
\text { All outcomes }\end{array}$ & Unclear risk & $\begin{array}{l}\text { Stated to be double-blind but no details pro- } \\
\text { vided }\end{array}$ \\
\hline $\begin{array}{l}\text { Blinding of outcome assessment (detection } \\
\text { bias) } \\
\text { All outcomes }\end{array}$ & Unclear risk & $\begin{array}{l}\text { Stated to be double-blind but no details pro- } \\
\text { vided }\end{array}$ \\
\hline $\begin{array}{l}\text { Incomplete outcome data (attrition bias) } \\
\text { All outcomes }\end{array}$ & Low risk & Loss to follow-up: $0 ; 0 \%$ \\
\hline Selective reporting (reporting bias) & Unclear risk & Study protocol not available \\
\hline Other bias & Unclear risk & Small study size \\
\hline Power calculation? & High risk & No power calculation \\
\hline
\end{tabular}

Lodge 2005a

Methods

Participants
Double-blind, placebo-controlled RCT

Adults

Partial hepatectomy for liver carcinoma/metastasis, benign tumours or anatomical/nonanatomical resection

Group $1=63$

Group $2=59$

Group $3=63$

Randomised but not given an allocated treatment $=19$

Total randomised $=204$

Interventions

Group 1. $20 \mu \mathrm{g} / \mathrm{kg}$ rFVIIa by slow iv, within 5 minutes before the first skin incision; repeated at 5 hours if operation likely to be longer than 6 hours. Total dose 20 or $40 \mu \mathrm{g} /$ $\mathrm{kg}$.

Group 2. $80 \mu \mathrm{g} / \mathrm{kg}$ as for group 1 . Total dose 80 or $160 \mu \mathrm{g} / \mathrm{kg}$.

Group 3. Placebo as for group 1.

Outcomes

1. (Primary) Patients requiring erythrocyte (red cell) transfusion during surgery and the 48-hour period after

2. Amount of erythrocytes (red cells) transfused 


\begin{tabular}{|c|c|c|}
\hline & \multicolumn{2}{|c|}{$\begin{array}{l}\text { 3. Change in haematocrit } \\
\text { 4. Proportion of patients who received perioperative transfusions of fresh frozen plasma } \\
\text { 5. Total surgery time } \\
\text { 6. Blood loss during and after surgery } \\
\text { 7. Adverse events especially thromboembolic events }\end{array}$} \\
\hline Sources of Support & \multicolumn{2}{|c|}{ Novo Nordisk set up randomisation, provided clinical researcher and statistician } \\
\hline Notes & \multicolumn{2}{|c|}{ Minimal threats to validity noted (see 'Risk of bias' assessment) } \\
\hline \multicolumn{3}{|l|}{ Risk of bias } \\
\hline Bias & Authors' judgement & Support for judgement \\
\hline $\begin{array}{l}\text { Random sequence generation (selection } \\
\text { bias) }\end{array}$ & Low risk & $\begin{array}{l}\text { Randomisation, blocked by centre, was com- } \\
\text { puter-generated by means of central interac- } \\
\text { tive voice response system }\end{array}$ \\
\hline Allocation concealment (selection bias) & Low risk & As above \\
\hline $\begin{array}{l}\text { Blinding of participants and personnel } \\
\text { (performance bias) } \\
\text { All outcomes }\end{array}$ & Low risk & Stated to be double-blind \\
\hline $\begin{array}{l}\text { Blinding of outcome assessment (detection } \\
\text { bias) } \\
\text { All outcomes }\end{array}$ & Low risk & $\begin{array}{l}\text { Stated to be double-blind. An additional mea- } \\
\text { sure was that clotting blood tests were not re- } \\
\text { leased from the central lab until the trial end }\end{array}$ \\
\hline $\begin{array}{l}\text { Incomplete outcome data (attrition bias) } \\
\text { All outcomes }\end{array}$ & Low risk & $\begin{array}{l}\text { Loss to follow-up: } 19 ; 9 \% .19 \text { patients lost } \\
\text { to follow-up did not undergo partial hepate- } \\
\text { ctomy and lack of clarity on whether losses } \\
\text { to follow-up were spread equally across each } \\
\text { treatment group }\end{array}$ \\
\hline Selective reporting (reporting bias) & Unclear risk & Study protocol not available \\
\hline Other bias & Low risk & - \\
\hline Power calculation? & Low risk & Done; target 180 (achieved) \\
\hline
\end{tabular}

\section{Lodge 2005b}

\begin{tabular}{ll} 
Methods & Double-blind, placebo-controlled RCT \\
\hline Participants & Adults \\
& End-stage liver disease with cirrhosis prior to orthotopic liver transplantation \\
& Group $1=63$ \\
Group $2=58$
\end{tabular}




\begin{tabular}{|c|c|}
\hline & $\begin{array}{l}\text { Group } 3=61 \\
\text { Randomised but not given an allocated treatment }=27 \\
\text { Total randomised }=209\end{array}$ \\
\hline Interventions & $\begin{array}{l}\text { Group 1. Repeated doses of } 60 \mu \mathrm{g} / \mathrm{kg} \mathrm{rFVIIa} \text { iv starting within } 10 \text { minutes of skin } \\
\text { incision and then repeated every } 2 \text { hours. Most participants had } 3 \text { doses. Total dose } \\
\text { approximately } 180 \mu \mathrm{g} / \mathrm{kg} \text {. } \\
\text { Group 2. As for group } 1 \text { but dose } 120 \mu \mathrm{g} / \mathrm{kg} \text {. Total dose approximately } 360 \mu \mathrm{g} / \mathrm{kg} \text {. } \\
\text { Group 3. Placebo. }\end{array}$ \\
\hline Outcomes & $\begin{array}{l}\text { 1. (Primary) Total number of red cells units transfused during the perioperative period } \\
\text { defined as surgery }+24 \text { hours postoperatively } \\
\text { 2. Other transfusion requirements (FFP, platelets, crystalloids and colloids) during peri- } \\
\text { operative period } \\
\text { 3. Blood loss during perioperative period and changes in haematocrit during periopera- } \\
\text { tive period } \\
\text { 4. Use of other haemostatic drugs, including antifibrinolytics } \\
\text { 5. Length of intensive care and hospital stay } \\
\text { 6. Surgery time } \\
\text { 7. Adverse events especially thromboembolic events and bleeding complications }\end{array}$ \\
\hline Sources of Support & One author from Novo Nordisk \\
\hline Notes & Important threats to validity noted (see 'Risk of bias' assessment) \\
\hline
\end{tabular}

Risk of bias

\begin{tabular}{|c|c|c|}
\hline Bias & Authors' judgement & Support for judgement \\
\hline $\begin{array}{l}\text { Random sequence generation (selection } \\
\text { bias) }\end{array}$ & Unclear risk & No details given \\
\hline Allocation concealment (selection bias) & Unclear risk & No details given \\
\hline $\begin{array}{l}\text { Blinding of participants and personnel } \\
\text { (performance bias) } \\
\text { All outcomes }\end{array}$ & Unclear risk & $\begin{array}{l}\text { Stated to be double-blind but no details pro- } \\
\text { vided }\end{array}$ \\
\hline $\begin{array}{l}\text { Blinding of outcome assessment (detection } \\
\text { bias) } \\
\text { All outcomes }\end{array}$ & Unclear risk & $\begin{array}{l}\text { Stated to be double-blind but no details pro- } \\
\text { vided }\end{array}$ \\
\hline $\begin{array}{l}\text { Incomplete outcome data (attrition bias) } \\
\text { All outcomes }\end{array}$ & Unclear risk & $\begin{array}{l}\text { Loss to follow-up: } 27 ; 13 \% \text { ( } 26 \text { withdrawn } \\
\text { before dosing and } 1 \text { did not complete prean- } \\
\text { hepatic phase of surgery) }\end{array}$ \\
\hline Selective reporting (reporting bias) & Unclear risk & Study protocol not available \\
\hline
\end{tabular}


Lodge 2005b (Continued)

\begin{tabular}{|c|c|c|}
\hline Other bias & Unclear risk & $\begin{array}{l}\text { Equality of allocation within each of the } 14 \\
\text { centres not assured }\end{array}$ \\
\hline Power calculation? & Low risk & Done; target 180 (achieved) \\
\hline
\end{tabular}

\section{Ma 2006}

\begin{tabular}{ll}
\hline Methods & Double-blind, placebo-controlled RCT \\
\hline Participants & $\begin{array}{l}\text { Adults } \\
\text { Cardiac valve replacement requiring cardio-pulmonary bypass } \\
\text { Group } 1=11 \\
\text { Group } 2=11 \\
\text { Total randomised }=22\end{array}$ \\
\hline Interventions & $\begin{array}{l}\text { Group } 1.1 \text { dose of } 40 \mu \text { g/kg rFVIIa iv after bypass and reversal of heparin. } \\
\text { Group 2. Placebo at same time. }\end{array}$ \\
\hline Outcomes & $\begin{array}{l}\text { 1. Serial haematological parameters including haemoglobin, haematocrit, platelets, PT, } \\
\text { INR, fibrinogen, ACT } \\
\text { 2. Postoperative thoracic drainage } \\
\text { 3. Postoperative blood transfusion } \\
\text { 4. Period of mechanical ventilation } \\
\text { 5. Period of ICU stay } \\
\text { 6. Hospitalisation costs }\end{array}$ \\
\hline Sources of Support & No statement made \\
\hline Notes & \begin{tabular}{l} 
Important threats to validity noted (see 'Risk of bias' assessment) \\
\hline
\end{tabular} \\
\hline
\end{tabular}

\section{Risk of bias}

\begin{tabular}{l|l|l} 
Bias & Authors' judgement & Support for judgement \\
\hline $\begin{array}{l}\text { Random sequence generation (selection } \\
\text { bias) }\end{array}$ & Low risk & $\begin{array}{l}\text { Randomisation was performed using random } \\
\text { number tables }\end{array}$ \\
\hline $\begin{array}{l}\text { Allocation concealment (selection bias) } \\
\begin{array}{l}\text { Blinding of participants and personnel } \\
\text { (performance bias) }\end{array}\end{array}$ & Unclear risk & No details given \\
\hline $\begin{array}{l}\text { All outcomes } \\
\text { Blinding of outcome assessment (detection } \\
\text { bias) }\end{array}$ & Unclear risk & $\begin{array}{l}\text { Stated to be double-blind but no details pro- } \\
\text { vided }\end{array}$ \\
\hline $\begin{array}{ll}\text { All } \\
\text { nutcomes }\end{array}$ & & $\begin{array}{l}\text { Stated to be double-blind but no details pro- } \\
\text { vided }\end{array}$
\end{tabular}

All outcomes 


\begin{tabular}{lll}
\hline $\begin{array}{l}\text { Incomplete outcome data (attrition bias) } \\
\text { All outcomes }\end{array}$ & Low risk & Loss to follow-up: 0; 0\% \\
\hline Selective reporting (reporting bias) & Unclear risk & Study protocol not available \\
\hline Other bias & Unclear risk & Small study size. No transfusion guidelines. \\
\hline Power calculation? & High risk & No power calculation \\
\hline
\end{tabular}

Mayer 2005a

Methods

Participants

Interventions

Sources of Support

Notes

Double-blind, placebo-controlled RCT

\section{Adults}

Spontaneous intracerebral haemorrhage confirmed by CT scan within 3 hours of onset

Group $1=108$

Group $2=92$

Group $3=103$

Group $4=96$

Total randomised $=400$ (one withdrew consent)

Group 1.1 dose of $40 \mu \mathrm{g} / \mathrm{kg}$ of iv FVIIa within 1 hour of scan.

Group 2. 1 dose of $80 \mu \mathrm{g} / \mathrm{kg}$ at same time.

Group 3. 1 dose of $160 \mu \mathrm{g} / \mathrm{kg}$ at same time.

Group 4. Placebo at same time.

\begin{tabular}{ll}
\hline Outcomes & 1. (Primary) Change in volume of intracerebral haemorrhage as assessed by CT scan \\
between baseline and 24 hours & 2. Survival at 90 days \\
3. Unfavourable Modified Rankin Scale score (4 to 6) at 90 days \\
4. Unfavourable Extended Glasgow Outcome Scale score (1 to 4$)$ at 90 days \\
5. Barthel Index score at 90 days \\
6. NIH Stroke Scale score at 90 days \\
7. All serious adverse events, particularly thromboembolic, up to 90 days (all adverse \\
events collected to discharge from hospital)
\end{tabular}

\begin{tabular}{ll} 
Sources of Support & $\begin{array}{l}\text { Study supported by Novo Nordisk. Sponsor responsible for collecting the data. } 5 \text { authors } \\
\text { received consultancy fees from Novo Nordisk. } 3 \text { authors from Novo Nordisk }\end{array}$ \\
\hline Notes & Some threats to validity (see 'Risk of bias' assessment)
\end{tabular}

\section{Risk of bias}

\begin{tabular}{|c|c|c|}
\hline Bias & Authors' judgement & Support for judgement \\
\hline $\begin{array}{l}\text { Random sequence generation (selection } \\
\text { bias) }\end{array}$ & Low risk & $\begin{array}{l}\text { Randomisation in blocks of } 4 \text { in sequentially } \\
\text { numbered, identical appearing containers }\end{array}$ \\
\hline
\end{tabular}




\begin{tabular}{|c|c|c|}
\hline Allocation concealment (selection bias) & Low risk & As above \\
\hline $\begin{array}{l}\text { Blinding of participants and personnel } \\
\text { (performance bias) } \\
\text { All outcomes }\end{array}$ & Low risk & $\begin{array}{l}\text { Stated to be double-blind. Indicated that } \\
\text { placebo identical. CT scans analysed in ran- } \\
\text { dom order, double-read, blind to treatment } \\
\text { allocation }\end{array}$ \\
\hline $\begin{array}{l}\text { Blinding of outcome assessment (detection } \\
\text { bias) } \\
\text { All outcomes }\end{array}$ & Low risk & As above \\
\hline $\begin{array}{l}\text { Incomplete outcome data (attrition bias) } \\
\text { All outcomes }\end{array}$ & Low risk & Loss to follow-up: $16 ; 4 \%$ \\
\hline Selective reporting (reporting bias) & Low risk & Registered at www.clinicaltrials.gov \\
\hline Other bias & Unclear risk & $\begin{array}{l}\text { Half of study patients had complete screen- } \\
\text { ing data, precluding full assessment of bal- } \\
\text { ance of population characteristics. Equality } \\
\text { of distribution of patients between the } 73 \\
\text { contributing study centres. Inclusion criteria } \\
\text { changed during trial to exclude those with his- } \\
\text { tory of thrombotic or vaso-occlusive disease - } \\
\text { distribution across final study groups not de- } \\
\text { scribed. In analysis for surviving patients with } \\
\text { missing outcome data, last observation was } \\
\text { carried forward }\end{array}$ \\
\hline Power calculation? & Unclear risk & Done; target not stated \\
\hline
\end{tabular}

\section{Mayer 2005b}

\begin{tabular}{ll} 
Methods & Double-blind, placebo-controlled RCT \\
\hline Participants & Adults \\
& Spontaneous intracerebral haemorrhage confirmed by CT scan within 3 hours of onset \\
& Groups $1,2,3,4,5,6=6$ \\
& Group $7=12$ \\
& Total randomised $=48$ (1 withdrew consent)
\end{tabular}

Interventions

Group 1.1 dose of $10 \mu \mathrm{g} / \mathrm{kg}$ of iv rFVIIa within 1 hour of scan.

Group 2.1 dose of $20 \mu \mathrm{g} / \mathrm{kg}$ at same time.

Group 3. 1 dose of $40 \mu \mathrm{g} / \mathrm{kg}$ at same time.

Group 4.1 dose of $80 \mu \mathrm{g} / \mathrm{kg}$ at same time.

Group 5.1 dose of $120 \mu \mathrm{g} / \mathrm{kg}$ at same time.

Group 6. 1 dose of $160 \mu \mathrm{g} / \mathrm{kg}$ at same time.

Group 7. Placebo within 1 hour of scan. 
Mayer 2005b (Continued)

\begin{tabular}{ll} 
Outcomes & $\begin{array}{l}\text { 1. (Primary) Frequency of adverse events that were possibly or probably treatment related } \\
\text { by day } 15 \text { or discharge if earlier. Serious adverse events were considered to day } 90 ; \text { pre- } \\
\text { defined events included MI, DVT, PE, cerebral artery or vein thrombosis, consumptive } \\
\text { coagulopathy, perihaematoma oedema } \\
\text { 2. Change in baseline and 24-hour CT } \\
\text { 3. In hospital neurological deterioration between day } 0 \text { and day } 5 \\
\text { 4. Percentage of patients dead, alive with minimal or no disability, or alive and function- } \\
\text { ally independent at day } 90\end{array}$ \\
\hline Sources of Support & Study supported by Novo Nordisk. Statistician from Novo Nordisk \\
\hline Notes & Some threats to validity (see 'Risk of bias' assessment)
\end{tabular}

\section{Risk of bias}

Bias Authors' judgement

Random sequence generation (selection Unclear risk bias)

\section{Support for judgement}

Randomisation schedule was generated and patients were allocated to the next available randomisation number within the dose tier. No details given about sequence generation

No details given

Stated to be double-blind. CT scans analysed in random sequence by 2 independent blinded neuroradiologists

As above

Blinding of outcome assessment (detection Low risk bias)

All outcomes

Incomplete outcome data (attrition bias) Low risk

Loss to follow-up: $1 ; 2 \%$

All outcomes

\begin{tabular}{|c|c|c|}
\hline Selective reporting (reporting bias) & Unclear risk & Study protocol not available \\
\hline Other bias & Unclear risk & $\begin{array}{l}\text { Small safety study with no power calculation. } \\
\text { Equality of distribution of patients between } \\
\text { centres. No comparison of population char- } \\
\text { acteristics between study arms }\end{array}$ \\
\hline Power calculation? & High risk & No power calculation \\
\hline
\end{tabular}


Mayer 2006

\begin{tabular}{|c|c|c|}
\hline Methods & \multicolumn{2}{|c|}{ Double-blind, placebo-controlled RCT } \\
\hline Participants & \multicolumn{2}{|c|}{$\begin{array}{l}\text { Adults } \\
\text { Spontaneous intracerebral haemorrhage confirmed by CT scan within } 3 \text { hours of onset } \\
\text { Group } 1=8 \\
\text { Group } 2=8 \\
\text { Group } 3=8 \\
\text { Group } 4=8 \\
\text { Group } 5=8 \\
\text { Randomised but not given an allocated treatment }=1 \\
\text { Total randomised = } 41\end{array}$} \\
\hline Interventions & \multicolumn{2}{|c|}{$\begin{array}{l}\text { Group } 1.1 \text { dose of } 5 \mu \mathrm{g} / \mathrm{kg} \text { of rFVIIa iv within } 1 \text { hour of CT scan. } \\
\text { Group 2. } 1 \text { dose of } 20 \mu \mathrm{g} / \mathrm{kg} \text { at same time. } \\
\text { Group 3. } 1 \text { dose of } 40 \mu \mathrm{g} / \mathrm{kg} \text { at same time. } \\
\text { Group } 4.1 \text { dose of } 80 \mu \mathrm{g} / \mathrm{kg} \text { at same time. } \\
\text { Group 5. Placebo at same time. }\end{array}$} \\
\hline Outcomes & \multicolumn{2}{|c|}{$\begin{array}{l}\text { 1. (Primary) Frequency of adverse events by day } 15 \text { or discharge if earlier. Serious adverse } \\
\text { events were considered to day } 90 \text {. Predefined events included MI, DVT, PE, cerebral } \\
\text { artery or vein thrombosis, consumptive coagulopathy, perihaematoma oedema } \\
\text { 2. Change in CT scan at } 1 \text { and } 24 \text { hours after baseline } \\
\text { 3. In hospital neurological deterioration between day } 0 \text { and day } 5 \\
\text { 4. Percentage of patients dead, alive with minimal or no disability, or alive and function- } \\
\text { ally independent at day } 90\end{array}$} \\
\hline Sources of Support & \multicolumn{2}{|c|}{$\begin{array}{l}\text { Study supported by Novo Nordisk. One author from Novo Nordisk. Agreement to } \\
\text { publish results regardless of outcome }\end{array}$} \\
\hline Notes & \multicolumn{2}{|c|}{ Some threats to validity noted (see 'Risk of bias' assessment) } \\
\hline \multicolumn{3}{|l|}{ Risk of bias } \\
\hline Bias & Authors' judgement & Support for judgement \\
\hline $\begin{array}{l}\text { Random sequence generation (selection } \\
\text { bias) }\end{array}$ & Unclear risk & $\begin{array}{l}\text { Randomly assigned in } 4 \text { sequential dose tiers } \\
\text { ( } \mathrm{n}=10 \text { per tier) to receive placebo }(\mathrm{n}=2 \\
\text { per tier) or product at } 4 \text { different doses }(\mathrm{n}= \\
8 \text { per tier). No details given about sequence } \\
\text { generation }\end{array}$ \\
\hline Allocation concealment (selection bias) & Unclear risk & No details given \\
\hline $\begin{array}{l}\text { Blinding of participants and personnel } \\
\text { (performance bias) } \\
\text { All outcomes }\end{array}$ & Low risk & $\begin{array}{l}\text { Stated to be double-blind. Active agent and } \\
\text { placebo were provided as indistinguishable } \\
\text { powders for reconstitution }\end{array}$ \\
\hline
\end{tabular}

Recombinant factor VIla for the prevention and treatment of bleeding in patients without haemophilia (Review) 


\section{Mayer 2006 (Continued)}

\begin{tabular}{|c|c|c|}
\hline $\begin{array}{l}\text { Blinding of outcome assessment (detection } \\
\text { bias) } \\
\text { All outcomes }\end{array}$ & Low risk & $\begin{array}{l}\text { Stated to be double-blind. CT scans anal- } \\
\text { ysed in random sequence by } 2 \text { independent } \\
\text { blinded neuroradiologists }\end{array}$ \\
\hline $\begin{array}{l}\text { Incomplete outcome data (attrition bias) } \\
\text { All outcomes }\end{array}$ & Low risk & Loss to follow-up: $1 ; 2 \%$ \\
\hline Selective reporting (reporting bias) & Unclear risk & Study protocol not available \\
\hline Other bias & Unclear risk & $\begin{array}{l}\text { Small study size. Equality of distribution of } \\
\text { patients among centres unclear. } 2 \text { patients } \\
(5 \%) \text { were treated beyond } 4 \text { hours of onset }\end{array}$ \\
\hline Power calculation? & High risk & No power calculation \\
\hline
\end{tabular}

Mayer 2008

Methods

Participants
Double-blind, placebo-controlled RCT

Adults

Spontaneous intracerebral haemorrhage confirmed by CT scan within 3 hours of onset

Group $1=265$

Group $2=293$

Group 3 = 263

Randomised but not given an allocated treatment $=20$

Total randomised $=841$

Interventions

Group 1.1 dose of $20 \mu \mathrm{g} / \mathrm{kg}$ of rFVIIa iv within 1 hour of CT scan.

Group 2. 1 dose of $80 \mu \mathrm{g} / \mathrm{kg}$ at same time.

Group 3. Placebo at same time.

Outcomes

1. (Primary) Severe disability or death by modified Rankin scale score of 5 or 6 at day 90

2. Clinical assessment scores at day 90: Barthel index, Extended Glasgow Outcome Scale, NIH Stroke Scale, EuroQoL scale and Revised Hamilton Rating Scale for Depression

3. Change in volume of intracerebral haemorrhage, intraventricular haemorrhage and oedema as assessed by CT scan between baseline, 24 and 72 hours

4. All adverse events until discharge and serious adverse events, particularly thromboembolic, up to 90 days

Sources of Support

Study supported by Novo Nordisk. Sponsor responsible for trial operations including data analysis

Notes

Some threats to validity noted (see 'Risk of bias' assessment)

\section{Risk of bias}


Mayer 2008 (Continued)

\begin{tabular}{|c|c|c|}
\hline Bias & Authors' judgement & Support for judgement \\
\hline $\begin{array}{l}\text { Random sequence generation (selection } \\
\text { bias) }\end{array}$ & Low risk & Block randomisation according to site \\
\hline Allocation concealment (selection bias) & Unclear risk & No details given \\
\hline $\begin{array}{l}\text { Blinding of participants and personnel } \\
\text { (performance bias) } \\
\text { All outcomes }\end{array}$ & Low risk & Stated to be double-blind \\
\hline $\begin{array}{l}\text { Blinding of outcome assessment (detection } \\
\text { bias) } \\
\text { All outcomes }\end{array}$ & Low risk & $\begin{array}{l}\text { CT scans analysed by } 2 \text { independent blinded } \\
\text { neuroradiologists }\end{array}$ \\
\hline $\begin{array}{l}\text { Incomplete outcome data (attrition bias) } \\
\text { All outcomes }\end{array}$ & Low risk & Loss to follow-up: $22 ; 3 \%$ \\
\hline Selective reporting (reporting bias) & Low risk & Registered at www.clinicaltrials.gov \\
\hline Other bias & Low risk & $\begin{array}{l}\text { External generalisability is a concern as less } \\
\text { than } 10 \% \text { who were assessed for eligibility for } \\
\text { the trial underwent randomisation. In anal- } \\
\text { ysis for surviving patients with missing out- } \\
\text { come data, last observation was carried for- } \\
\text { ward }\end{array}$ \\
\hline Power calculation? & Low risk & Done; target 816 (achieved) \\
\hline
\end{tabular}

\section{Narayan 2008}

Methods

Participants
Double-blind, placebo-controlled RCT

Dose-escalation trial

Adult

Traumatic brain injury with contusion of total volume of at least $2 \mathrm{~mL}$ on CT scan obtained within 6 hours of injury

Group $1=12$

Group $2=11$

Group $3=14$

Group $4=12$

Group $5=12$

Group $6=36$

Total randomised $=97$

Interventions

Group 1. 1 dose of $40 \mu \mathrm{g} / \mathrm{kg}$ of rFVIIa iv within 2.5 hours of CT scan.

Group 2. 1 dose of $80 \mu \mathrm{g} / \mathrm{kg}$ at same time.

Group 3. 1 dose of $120 \mu \mathrm{g} / \mathrm{kg}$ at same time. 
Group 4. 1 dose of $160 \mu \mathrm{g} / \mathrm{kg}$ at same time.

Group 5. 1 dose of $200 \mu \mathrm{g} / \mathrm{kg}$ at same time.

Group 6. Placebo at same time.

Outcomes

Sources of Support

Notes
1. (Primary) Safety: occurrence of AEs, serious AEs, predefined potential thromboembolic AEs (deep venous thrombosis, pulmonary embolus, myocardial infarction, cerebral infarction, DIC, coagulopathy) and mortality within 15-day trial period

2. Changes in haematoma volume on CT scan at baseline compared with 24 hours and 72 hours after dosing

3. Clinical outcomes at day 15: Glasgow Coma Scale, extended Glasgow Outcome Scale and Barthel Index

Novo Nordisk supplied study agent and placebo. 2 authors from Novo Nordisk

Some threats to validity noted (see 'Risk of bias' assessment)

\section{Risk of bias}

\begin{tabular}{|c|c|c|}
\hline Bias & Authors' judgement & Support for judgement \\
\hline $\begin{array}{l}\text { Random sequence generation (selection } \\
\text { bias) }\end{array}$ & Unclear risk & No details given \\
\hline Allocation concealment (selection bias) & Unclear risk & No details given \\
\hline $\begin{array}{l}\text { Blinding of participants and personnel } \\
\text { (performance bias) } \\
\text { All outcomes }\end{array}$ & Unclear risk & $\begin{array}{l}\text { Stated as double-blind but no details pro- } \\
\text { vided }\end{array}$ \\
\hline $\begin{array}{l}\text { Blinding of outcome assessment (detection } \\
\text { bias) } \\
\text { All outcomes }\end{array}$ & Low risk & $\begin{array}{l}2 \text { independent neuroradiologists assessed } \\
\text { CT scans masked to patient, treatment arm } \\
\text { and study site information }\end{array}$ \\
\hline $\begin{array}{l}\text { Incomplete outcome data (attrition bias) } \\
\text { All outcomes }\end{array}$ & Low risk & Loss to follow-up: $0 ; 0 \%$ \\
\hline Selective reporting (reporting bias) & Low risk & Registered at www.clinicaltrials.gov \\
\hline Other bias & Unclear risk & $\begin{array}{l}\text { Inclusion criteria amended after } 8 \% \text { of pa- } \\
\text { tients entered study to improve recruitment } \\
\text { (reducing minimal lesion volume from } 5 \\
\mathrm{~mL} \text { to } 2 \mathrm{~mL} \text {; GCS scores changed from } 4 \text { - } \\
13 \text { to } 4-14 \text {; time of CT scan from within } 4 \\
\text { to within } 6 \text { hours). External generalisabil- } \\
\text { ity is a concern as } 4 \% \text { who were assessed } \\
\text { for eligibility for the trial underwent ran- } \\
\text { domisation. Follow-up data available up to } \\
15 \text { days post-dosing }\end{array}$ \\
\hline
\end{tabular}


Narayan 2008 (Continued)

\begin{tabular}{|c|c|}
\hline Power calculation? & No power calculation \\
\hline \multicolumn{2}{|l|}{ Pihusch 2005} \\
\hline Methods & Double-blind, placebo-controlled RCT \\
\hline Participants & $\begin{array}{l}\text { Adults (all included patients }>16 \text { years old, although inclusion criteria allowed }>12 \\
\text { years) } \\
\text { Bleeding occurring } 2 \text { to } 120 \text { days (or } 180 \text { days later in study) after haematopoietic } \\
\text { stem cell grafts (initially allogeneic, later in study autologous included) for a variety of } \\
\text { haematological and oncological conditions } \\
\text { Group } 1=20 \\
\text { Group } 2=26 \\
\text { Group } 3=31 \\
\text { Group } 4=23 \\
\text { Total randomised }=100\end{array}$ \\
\hline Interventions & $\begin{array}{l}\text { Group } 1.7 \times 40 \mu \mathrm{g} / \mathrm{kg} \text { of iv rFVIIa given every } 6 \text { hours; total dose } 280 \mu \mathrm{g} / \mathrm{kg} \text {. } \\
\text { Group 2. As for group } 1 \text {, but } 7 \times 80 \mu \mathrm{g} / \mathrm{kg} \text {; total dose } 560 \mu \mathrm{g} / \mathrm{kg} \text {. } \\
\text { Group 3. As for group } 1 \text { but } 7 \times 160 \mu \mathrm{g} / \mathrm{kg} \text {; total dose } 1120 \mu \mathrm{g} / \mathrm{kg} \text {. } \\
\text { Group } 4 \text {. Placebo. }\end{array}$ \\
\hline
\end{tabular}

Outcomes

1. (Primary) Change in bleeding score (5-point scale 0 to 4 ) from baseline to 38 hours after initial dose

2. Changes in bleeding scores over other periods

3. Use of RBC, platelets and FFP over 96-hour trial period

4. Adverse events and serious adverse events over 96-hour trial period

Sources of Support

Novo Nordisk support in all phases of the trial. 2 authors from Novo Nordisk

Notes

Important threats to validity noted (see 'Risk of bias' assessment)

\section{Risk of bias}

\begin{tabular}{lll} 
Bias & Authors' judgement & Support for judgement \\
\hline $\begin{array}{l}\text { Random sequence generation (selection } \\
\text { bias) }\end{array}$ & Low risk & $\begin{array}{l}\text { Computer-generated, using centre blocks } \\
\text { with equal allocation ratio between treatment } \\
\text { groups }\end{array}$ \\
\hline Allocation concealment (selection bias) & Low risk & As above
\end{tabular}

Blinding of participants and personnel Low risk (performance bias)

Stated to be double-blind. Indicated that All outcomes placebo identical. 
Pihusch 2005 (Continued)

Blinding of outcome assessment (detection Low risk bias)

All outcomes
Stated to be double-blind.

Loss to follow-up: $2 ; 2 \%$

All outcomes

\begin{tabular}{|c|c|c|}
\hline Selective reporting (reporting bias) & Unclear risk & Study protocol not available \\
\hline Other bias & High risk & $\begin{array}{l}\text { Stopped recruiting patients where bleeding } \\
\text { event triggering trial entry was haemorrhagic } \\
\text { cystitis (HC) ("bleeding from urinary blad- } \\
\text { der") after an interim analysis (p1938 col2) } \\
\text {. However, there was a marked imbalance } \\
\text { in patients with } \mathrm{HC} \text { across study groups be- } \\
\text { ing much reduced in the } 80 \mu \mathrm{g} / \mathrm{kg} \text { treatment } \\
\text { group }\end{array}$ \\
\hline Power calculation? & Low risk & Done; target 100 (achieved) \\
\hline
\end{tabular}

Planinsic 2005

\section{Methods}

Participants
Double-blind, placebo-controlled RCT

Adults

End-stage liver disease prior to orthotopic liver transplantation

Group $1=18$

Group $2=24$

Group $3=22$

Group $4=19$

Randomised but not given an allocated treatment $=4$

Total randomised $=87$

Interventions

Group 1. 1 dose rFVIIa $20 \mu \mathrm{g} / \mathrm{kg}$ iv within 10 minutes of the first skin incision.

Group 2. 1 dose $40 \mu \mathrm{g} / \mathrm{kg}$ FVIIa, otherwise as for group 1 .

Group 3. 1 dose $80 \mu \mathrm{g} / \mathrm{kg}$ FVIIa, otherwise as for group 1.

Group 4. Placebo.
1. (Primary) Total number of red cells units transfused during the perioperative period defined as surgery +24 hours postoperatively

2. Other transfusion requirements during the perioperative period (FFP, platelets, crystalloids and colloids)

3. Blood loss recorded during the perioperative period

4. Use of other haemostatic drugs, including antifibrinolytics

5. Length of intensive care unit stay

6. Adverse events especially thromboembolic events and bleeding complications 
Planinsic 2005 (Continued)

\begin{tabular}{|c|c|c|}
\hline Notes & \multicolumn{2}{|c|}{ Some threats to validity noted (see 'Risk of bias' assessment) } \\
\hline \multicolumn{3}{|l|}{ Risk of bias } \\
\hline Bias & Authors' judgement & Support for judgement \\
\hline $\begin{array}{l}\text { Random sequence generation (selection } \\
\text { bias) }\end{array}$ & Unclear risk & $\begin{array}{l}\text { In blocks of } 8 \text { equally allocated across } 4 \text { treat- } \\
\text { ment groups. No other details }\end{array}$ \\
\hline Allocation concealment (selection bias) & Unclear risk & No details given \\
\hline $\begin{array}{l}\text { Blinding of participants and personnel } \\
\text { (performance bias) } \\
\text { All outcomes }\end{array}$ & Low risk & Stated to be double-blind \\
\hline $\begin{array}{l}\text { Blinding of outcome assessment (detection } \\
\text { bias) } \\
\text { All outcomes }\end{array}$ & Low risk & Stated to be double-blind \\
\hline $\begin{array}{l}\text { Incomplete outcome data (attrition bias) } \\
\text { All outcomes }\end{array}$ & Low risk & Loss to follow-up: $5 ; 5 \%$ \\
\hline Selective reporting (reporting bias) & Unclear risk & Study protocol not available \\
\hline Other bias & Low risk & - \\
\hline Power calculation? & Low risk & Done; target 80 (achieved) \\
\hline
\end{tabular}

\section{Pugliese 2007}

\begin{tabular}{ll}
\hline Methods & Double-blind, placebo-controlled RCT \\
\hline Participants & $\begin{array}{l}\text { Adults } \\
\text { End-stage liver disease prior to orthotopic liver transplantation } \\
\text { Group } 1=10 \\
\text { Group } 2=10 \\
\text { Total randomised }=20\end{array}$ \\
\hline Interventions & $\begin{array}{l}\text { Group } 1.1 \text { dose of } 40 \mu \mathrm{g} / \mathrm{kg} \text { rFVIIa iv immediately before anaesthesia induction. } \\
\text { Group } 2 . \text { Placebo at same time. }\end{array}$ \\
\hline Outcomes & $\begin{array}{l}\text { 1. Change in INR } \\
\text { 2. Blood products transfused during surgery } \\
\text { 3. Blood loss during surgery }\end{array}$ \\
\hline Sources of Support & No statement made
\end{tabular}


Pugliese 2007 (Continued)

\begin{tabular}{|c|c|c|}
\hline Notes & \multicolumn{2}{|c|}{ Important threats to validity noted (see 'Risk of bias' assessment) } \\
\hline \multicolumn{3}{|l|}{ Risk of bias } \\
\hline Bias & Authors' judgement & Support for judgement \\
\hline $\begin{array}{l}\text { Random sequence generation (selection } \\
\text { bias) }\end{array}$ & Unclear risk & No details given \\
\hline Allocation concealment (selection bias) & Unclear risk & No details given \\
\hline $\begin{array}{l}\text { Blinding of participants and personnel } \\
\text { (performance bias) } \\
\text { All outcomes }\end{array}$ & Unclear risk & $\begin{array}{l}\text { Stated to be double-blind but no details pro- } \\
\text { vided }\end{array}$ \\
\hline $\begin{array}{l}\text { Blinding of outcome assessment (detection } \\
\text { bias) } \\
\text { All outcomes }\end{array}$ & Unclear risk & $\begin{array}{l}\text { Stated to be double-blind but no details pro- } \\
\text { vided }\end{array}$ \\
\hline $\begin{array}{l}\text { Incomplete outcome data (attrition bias) } \\
\text { All outcomes }\end{array}$ & Low risk & Loss to follow-up: $0 ; 0 \%$ \\
\hline Selective reporting (reporting bias) & Unclear risk & $\begin{array}{l}\text { Some results reported in abstract but not in } \\
\text { results section }\end{array}$ \\
\hline Other bias & Unclear risk & $\begin{array}{l}\text { Not enough information to determine if } \\
\text { groups were balanced. Small study size }\end{array}$ \\
\hline Power calculation? & High risk & No power calculation \\
\hline
\end{tabular}

Raobaikady 2005

\begin{tabular}{ll}
\hline Methods & Double-blind, placebo-controlled RCT \\
\hline Participants & $\begin{array}{l}\text { Adults } \\
\text { Reconstructive surgery for traumatic fractures of the pelvis or pelvis and acetabulum } \\
\text { Group } 1=24 \\
\text { Group } 2=24 \\
\text { Total randomised }=48\end{array}$ \\
\hline Interventions & $\begin{array}{l}\text { Group } 1.90 \mu / \mathrm{kg} \text { rFVIIa iv at first skin incision plus a further dose after } 2 \text { hours if there } \\
\text { was evidence of significant bleeding. Total dose } 90 \text { to } 180 \mu \mathrm{gg} / \mathrm{kg} .\end{array}$ \\
\hline Group 2. Placebo. \\
\hline Outcomes & $\begin{array}{l}\text { 1. (Primary) Total volume of perioperative blood loss (surgery }+48 \text { hours postoperatively) } \\
\text { 2. Transfusion requirements }\end{array}$ \\
$\begin{array}{l}\text { 3. Numbers of patients transfused } \\
\text { 4. Volume of crystalloids/colloids infused }\end{array}$ \\
\hline
\end{tabular}

Recombinant factor VIla for the prevention and treatment of bleeding in patients without haemophilia (Review)

Copyright $\odot 2012$ The Cochrane Collaboration. Published by John Wiley \& Sons, Ltd. 
Raobaikady 2005 (Continued)

\begin{tabular}{|c|c|c|}
\hline & \multicolumn{2}{|c|}{$\begin{array}{l}\text { 5. Surgery time } \\
\text { 6. Time to reach normal body temperature and acid-base status } \\
\text { 7. Time in ICU } \\
\text { 8. Days in hospital } \\
\text { 9. Number of times returned to operating theatre } \\
\text { 10. Adverse events focusing on thromboembolic events }\end{array}$} \\
\hline Sources of Support & \multicolumn{2}{|c|}{$\begin{array}{l}\text { Study supported by Novo Nordisk. Novo Nordisk assisted in preparation of manuscript. } \\
\text { One author worked as consultant for Novo Nordisk }\end{array}$} \\
\hline Notes & \multicolumn{2}{|c|}{ Some threats to validity noted (see 'Risk of bias' assessment) } \\
\hline \multicolumn{3}{|l|}{ Risk of bias } \\
\hline Bias & Authors' judgement & Support for judgement \\
\hline $\begin{array}{l}\text { Random sequence generation (selection } \\
\text { bias) }\end{array}$ & Low risk & Computer-generated scheme \\
\hline Allocation concealment (selection bias) & Unclear risk & No details given \\
\hline $\begin{array}{l}\text { Blinding of participants and personnel } \\
\text { (performance bias) } \\
\text { All outcomes }\end{array}$ & Unclear risk & $\begin{array}{l}\text { Stated to be double-blind but no details pro- } \\
\text { vided }\end{array}$ \\
\hline $\begin{array}{l}\text { Blinding of outcome assessment (detection } \\
\text { bias) } \\
\text { All outcomes }\end{array}$ & Unclear risk & $\begin{array}{l}\text { Stated to be double-blind but no details pro- } \\
\text { vided }\end{array}$ \\
\hline $\begin{array}{l}\text { Incomplete outcome data (attrition bias) } \\
\text { All outcomes }\end{array}$ & Low risk & Loss to follow-up: $0 ; 0 \%$ \\
\hline Selective reporting (reporting bias) & Unclear risk & Study protocol not available \\
\hline Other bias & Low risk & - \\
\hline Power calculation? & Low risk & Done; target 48 (achieved) \\
\hline
\end{tabular}

Sachs 2007

Methods

Double-blind, placebo-controlled RCT

Participants

Adults

Spinal fusion surgery reaching dosing trigger of $10 \%$ loss of estimated blood volume with total expected loss of at least $20 \%$ estimated blood volume before end of surgery

Group $1=12$

Group $2=12$

Group $3=12$

Recombinant factor VIla for the prevention and treatment of bleeding in patients without haemophilia (Review) 
Sachs 2007 (Continued)

\begin{tabular}{ll} 
& $\begin{array}{l}\text { Group } 4=13 \\
\text { Randomised but not given an allocated treatment = } 11 \\
\text { Total randomised }=60\end{array}$ \\
\hline Interventions & $\begin{array}{l}\text { Group } 1.3 \times 30 \mu \mathrm{g} / \mathrm{kg} \mathrm{rFVIIa} \mathrm{iv.} \mathrm{First} \mathrm{dose} \mathrm{at} \mathrm{dosing} \mathrm{trigger;} \mathrm{second} \mathrm{dose} \mathrm{at} 2 \text { hours } \\
\text { after initial dose; third dose at } 4 \text { hours after initial dose. Total dose } 90 \mu \mathrm{g} / \mathrm{kg} . \\
\text { Group } 2.3 \times 60 \mu \mathrm{g} / \mathrm{kg} \mathrm{rFVIIa} \text { iv at same times. Total dose } 180 \mu \mathrm{g} / \mathrm{kg} .\end{array}$ \\
$\begin{array}{l}\text { Group } 3.3 \times 120 \mu \mathrm{g} / \mathrm{kg} \text { rFVIIa iv at same times. Total dose } 360 \mu \mathrm{g} / \mathrm{kg} . \\
\text { Group } 4 . \text { Placebo, powder for reconstitution, at same times. }\end{array}$ \\
\hline Outcomes & $\begin{array}{l}\text { 1. (Primary) All serious adverse events to } 30 \text { days post-surgery, thrombotic serious adverse } \\
\text { events, changes in laboratory parameters and all adverse events from baseline visit until } \\
\text { discharge }\end{array}$ \\
$\begin{array}{l}\text { 2. (Co-primary) Adjusted volume of blood loss } \\
\text { 3. Rate of blood loss }\end{array}$ \\
$\begin{array}{l}\text { 4. Units/volume of allogeneic and autologous RBC, FFP, platelets and cryoprecipitate } \\
\text { transfused } \\
\text { 5. Duration of surgery } \\
\text { 6. Time to drain removal }\end{array}$ \\
\hline Study supported by Novo Nordisk. 2 authors from Novo Nordisk. \\
\hline Notes
\end{tabular}

Risk of bias

\begin{tabular}{l|l|l} 
Bias & Authors' judgement & Support for judgement \\
\hline $\begin{array}{l}\text { Random sequence generation (selection } \\
\text { bias) }\end{array}$ & Unclear risk & No details given \\
\hline Allocation concealment (selection bias) & Unclear risk & No details given \\
\hline $\begin{array}{l}\text { Blinding of participants and personnel } \\
\text { (performance bias) } \\
\text { All outcomes }\end{array}$ & Low risk & $\begin{array}{l}\text { Stated to be double-blind. Active agent and } \\
\text { placebo were provided as indistinguishable } \\
\text { powders for reconstitution }\end{array}$ \\
\hline
\end{tabular}

Blinding of outcome assessment (detection Low risk bias)

Stated to be double-blind

All outcomes

Incomplete outcome data (attrition bias) Unclear risk All outcomes

Loss to follow-up; $11 ; 18 \%$ (all 11 did not reach dosing trigger)

\begin{tabular}{|c|c|c|}
\hline Selective reporting (reporting bias) & Unclear risk & Study protocol not available \\
\hline Other bias & Unclear risk & $\begin{array}{l}\text { Unclear if groups were balanced. Power cal- } \\
\text { culation based on assumed increase in throm- } \\
\text { botic events from } 2 \% \text { for placebo to } 15 \%\end{array}$ \\
\hline
\end{tabular}


Sachs 2007 (Continued)

for rFVIIa leading to an underpowered study. Marked differences between the unadjusted and adjusted analyses.

$\begin{array}{lll}\text { Power calculation? } & \text { Low risk } & \text { Done; target } 48 \text { (achieved) }\end{array}$

Shao 2006

Methods

Double-blind, placebo-controlled RCT

Participants

Adults

Partial hepatectomy for liver cancer or benign tumours in patients with cirrhosis

Group $1=71$

Group $2=74$

Group $3=76$

Randomised but not given an allocated treatment $=14$

Total randomised $=235$

Interventions

Group 1. First dose of $50 \mu \mathrm{g} / \mathrm{kg}$ rFVIIa iv within 10 minutes before first skin cut with additional doses given every 2 hours until the end of surgery to a maximum dose of 4 doses.

Group 2. $100 \mu \mathrm{g} / \mathrm{kg}$ iv as for Group 1.

Group 3. Placebo as for Group 1.

\section{Outcomes}

1. (Primary) Proportion of patients receiving RBC transfusions during surgery and the first 48 hours after surgery

2. (Co-primary) Amount of RBCs transfused during surgery and the first 48 hours after surgery

3. Amounts of FFP and platelets transfused during surgery and the first 48 hours after surgery

4. Blood loss

5. Proportion of patients receiving systemic haemostatic drugs

6. Changes in coagulation-related parameters including PTT, platelet counts, fibrinogen,

D-dimer, thrombin-anti-thrombin complexes, prothrombin fragments $1+2$ )

Sources of Support

One author from Novo Nordisk

Notes

Some threats to validity noted (see 'Risk of bias' assessment)

Risk of bias

\begin{tabular}{l|ll}
\hline Bias & Authors' judgement & Support for judgement \\
\hline $\begin{array}{l}\text { Random sequence generation (selection } \\
\text { bias) }\end{array}$ & Unclear risk & No details given \\
\hline Allocation concealment (selection bias) & Unclear risk & No details given
\end{tabular}




\begin{tabular}{l|l|l}
\hline $\begin{array}{l}\text { Blinding of participants and personnel } \\
\text { (performance bias) } \\
\text { All outcomes }\end{array}$ & Unclear risk & $\begin{array}{l}\text { Stated to be double-blind but no details pro- } \\
\text { vided }\end{array}$ \\
\hline $\begin{array}{l}\text { Blinding of outcome assessment (detection } \\
\text { bias) } \\
\text { All outcomes }\end{array}$ & Unclear risk & $\begin{array}{l}\text { Stated to be double-blind but no details pro- } \\
\text { vided }\end{array}$ \\
\hline $\begin{array}{l}\text { Incomplete outcome data (attrition bias) } \\
\text { All outcomes }\end{array}$ & Low risk & Loss to follow-up: 14; 6\% \\
\hline $\begin{array}{l}\text { Selective reporting (reporting bias) } \\
\text { Other bias }\end{array}$ & Unclear risk & Study protocol not available \\
\hline \begin{tabular}{l} 
Power calculation? \\
\hline
\end{tabular} & Low risk & - \\
\hline
\end{tabular}

$\mathrm{ACT}=$ activated clotting time

$\mathrm{AE}=$ adverse event

ASA = acetylsalicylic acid

$\mathrm{CPB}=$ cardiopulmonary bypass

$\mathrm{CT}=$ computerised tomography

$\mathrm{DIC}=$ disseminated intravascular coagulation

DVT $=$ deep vein thrombosis

FDP $=$ fibrin degradation products

$\mathrm{FFP}=$ fresh frozen plasma

GCS $=$ Glasgow Coma Scale

$\mathrm{ICU}=$ intensive care unit

INR = international normalised ratio

iv $=$ intravenous

$\mathrm{MI}=$ myocardial infarction

MOF = multiple organ failure $(\mathrm{MOF})$

$\mathrm{NIH}=$ National Institutes of Health

$\mathrm{PE}=$ pulmonary embolism

$\mathrm{PT}=$ prothrombin time

$\mathrm{RBC}=$ red blood cell

$\mathrm{RCT}=$ randomised controlled trial

rFVIIa = recombinant factor VIIa

$\mathrm{SOF}=$ single organ failure 
Characteristics of excluded studies [ordered by study ID]

\begin{tabular}{|c|c|}
\hline Study & Reason for exclusion \\
\hline Ashrani 2006 & Not a randomised controlled trial \\
\hline Bijsterveld 2002 & Study of human volunteers \\
\hline Bijsterveld 2004 & Study of human volunteers \\
\hline Boffard 2009 & Secondary report \\
\hline Bysted 2007 & Study of human volunteers \\
\hline Davis 2004 & Not a randomised controlled trial \\
\hline Diringer 2007 & Not a randomised controlled trial \\
\hline Elgafy 2010 & Systematic review or meta-analysis \\
\hline Ensor 2011 & Systematic review or meta-analysis \\
\hline Fridberg 2005 & Study of human volunteers \\
\hline Gurusamy 2009 & Systematic review or meta-analysis \\
\hline Jilma 2002 & Study of human volunteers \\
\hline Johansson 2010 & Systematic review or meta-analysis \\
\hline Kolban 2005 & Not a randomised controlled trial \\
\hline Larsen 2010 & Laboratory-based study \\
\hline Leduc 2009 & Systematic review or meta-analysis \\
\hline Levi 2010 & Systematic review or meta-analysis \\
\hline Lin $2011 b$ & Published version of previous Cochrane review \\
\hline Logan 2010 & Narrative review \\
\hline Macieji 2004 & Not a randomised controlled trial \\
\hline Nishijima 2009 & Systematic review or meta-analysis \\
\hline Perel 2010 & Systematic review or meta-analysis \\
\hline
\end{tabular}


(Continued)

\begin{tabular}{|c|c|}
\hline Perez 2007 & Not a randomised controlled trial \\
\hline Plaat 2007 & Not a randomised controlled trial \\
\hline Pugh 2007 & Not a randomised controlled trial \\
\hline Strydom 2010 & Systematic review or meta-analysis \\
\hline Thabut 2011 & Systematic review or meta-analysis \\
\hline Van De Velde 2007 & Not a randomised controlled trial \\
\hline Vincent 2009 & $\begin{array}{l}\text { Study was discontinued prematurely by the Safety Committee based on statistical analysis of the mortality in } \\
\text { cohort } 3 \text {, which suggested that } 28 \text {-day mortality was significantly higher in this cohort than in the placebo } \\
\text { group and time to death was significantly shorter }\end{array}$ \\
\hline Vink 2004 & Study of human volunteers \\
\hline Woltz 2004 & Study of human volunteers \\
\hline Yank 2009 & Not a randomised controlled trial \\
\hline Yank 2011 & Systematic review or meta-analysis \\
\hline Yuan 2010 & Systematic review or meta-analysis \\
\hline
\end{tabular}

\section{Characteristics of ongoing studies [ordered by study ID]}

\section{Arai 2005}

\begin{tabular}{ll} 
Trial name or title & $\begin{array}{l}\text { Randomised, double-blind, multicentre, placebo-controlled dose-escalation study to evaluate the safety and } \\
\text { preliminary efficacy of activated recombinant factor VII (NN-007) in acute intracerebral haemorrhage }\end{array}$ \\
\hline Methods & $\begin{array}{l}\text { Double-blind, placebo-controlled RCT } \\
\text { Dose-escalation trial }\end{array}$ \\
\hline Participants & $\begin{array}{l}\text { Adults } \\
\text { Spontaneous ICH diagnosed by CT scan within } 3 \text { hours of symptom onset } \\
\text { Group } 1=15 \\
\text { Group } 2=15 \\
\text { Group } 3=15 \\
\text { Group } 4=45 \\
\text { Total randomised }=90\end{array}$
\end{tabular}

Interventions Group 1.1 dose of $40 \mu \mathrm{g} / \mathrm{kg}$ of rFVIIa iv within 1 hour of CT scan.

Group 2. 1 dose of $80 \mu \mathrm{g} / \mathrm{kg}$ at same time.

Group 3. 1 dose of $120 \mu \mathrm{g} / \mathrm{kg}$ at same time. 
Group 4. Placebo at same time.

\begin{tabular}{ll}
\hline Outcomes & $\begin{array}{l}\text { 1. Modified Rankin Scale, Barthel Index scores at } 15 \text { days post-dose and } 90 \text { days post-dose } \\
\text { 2. Change in volume of intracerebral haemorrhage, total haemorrhage volume (intracerebral haemorrhage + } \\
\text { intraventricular haemorrhage) and total lesion volumes (ICH + IVH + oedema) as assessed by CT scan from } \\
\text { baseline to 24, } 48 \text { and } 72 \text { hours post-dose } \\
\text { 3. Change in Glasgow Coma Scale and the National Institute of Health's Stroke Scale (NIHSS) scores from } \\
\text { baseline to } 1 \text { hour, } 24 \text { hours, } 48 \text { hours, } 72 \text { hours, } 15 \text { days and } 90 \text { days post-dose } \\
\text { 4. Mortality at } 90 \text { days post-dose } \\
\text { 5. Occurrence of thromboembolic serious adverse events } \\
\text { 6. Changes in laboratory coagulation parameters from prior to dosing to 1, 24, } 48 \text { and } 72 \text { hours post-dose } \\
\text { 7. Occurrence of adverse events until discharge or } 90 \text { days post-dose, whichever came first and serious adverse } \\
\text { events }\end{array}$ \\
\hline Starting date & January 2006 to April 2007 \\
\hline Contact information & Morio Arai MD, PhD, Study Director, Novo Nordisk Pharma Ltd. \\
\hline Notes & Completed. Not yet published. \\
\hline
\end{tabular}

\section{Flaherty 2008}

\begin{tabular}{|c|c|}
\hline Trial name or title & The spot sign for predicting and treating intracerebral haemorrhage growth \\
\hline Methods & Double-blind, placebo-controlled RCT \\
\hline Participants & $\begin{array}{l}\text { Participants with ICH who are determined by CT angiogram to be at high risk for haemorrhage growth (CT } \\
\text { angiogram "spot sign" positive) } \\
\text { Estimated enrolment: } 184\end{array}$ \\
\hline Interventions & Recombinant FVIIa \\
\hline Outcomes & $\begin{array}{l}\text { 1. Life-threatening thromboembolic complications (acute myocardial infarction, acute cerebral ischaemia and } \\
\text { acute pulmonary embolism) } \\
\text { 2. Rate of haematoma growth } \\
\text { 3. Sensitivity and specificity of the spot sign for predicting haematoma growth } \\
\text { 4. Incidence of other thromboembolic complications (deep venous thrombosis, elevations in troponin not } \\
\text { associated with ECG changes) } \\
\text { 5. Modified Rankin Scale score at } 90 \text { days } \\
\text { 6. Positive and negative predictive values of the spot sign }\end{array}$ \\
\hline Starting date & November 2010 to January 2013 \\
\hline Contact information & Janice A. Carrozzella, RN, BA, RT(R) \\
\hline Notes & Recruiting \\
\hline
\end{tabular}


Gajewski 2005

\begin{tabular}{|c|c|}
\hline Trial name or title & $\begin{array}{l}\text { A multi-center, randomized, double-blind, parallel groups, placebo-controlled trial on efficacy and safety } \\
\text { of activated recombinant factor VII (rFVIIa/NovoSeven) in the treatment of bleeding in patients following } \\
\text { hematopoietic stem cell transplantation (HSCT) }\end{array}$ \\
\hline Methods & Double-blind, placebo-controlled RCT \\
\hline Participants & $\begin{array}{l}\text { Patients } \geq 12 \text { years } \\
\text { Post HSCT with active bleeding } \\
\text { Group } 1=4 \\
\text { Group } 2=4 \\
\text { Group } 3=3 \\
\text { Total randomised }=11\end{array}$ \\
\hline Interventions & $\begin{array}{l}\text { Group 1. } 2 \text { days of rFVIIa } 40 \mu \mathrm{g} / \mathrm{kg} \text { every } 6 \text { hours }(7 \mathrm{doses}) \text { plus standard therapy. Total dose } 280 \mu \mathrm{g} / \mathrm{kg} \text {. } \\
\text { Group 2. } 80 \mu \mathrm{g} / \mathrm{kg} \text { as for Group } 1 \text {. Total dose } 560 \mu \mathrm{g} / \mathrm{kg} \text {. } \\
\text { Group 3. Placebo as for Group 1. }\end{array}$ \\
\hline Outcomes & $\begin{array}{l}\text { 1. (Primary) Effect on bleeding after } 38 \text {-hour observation period following initial dosing } \\
\text { 2. Transfusion requirements for RBCs, platelets, FFP in a } 4 \text {-day observation period } \\
\text { 3. Bleeding evaluation at time points of } 24,48,72 \text {, and } 96 \text { hours } \\
\text { 4. Adverse events were recorded for the } 38 \text {-hour observation period plus an additional } 58 \text { hours ( } 96 \text { hours of } \\
\text { safety assessments) } \\
\text { 5. Changes in safety coagulation parameters }\end{array}$ \\
\hline Starting date & June 2002 to October 2003 \\
\hline Contact information & James L. Gajewski \\
\hline Notes & Trial was prematurely terminated due to excessively slow patient recruitment. Planned for 75 ( 25 per arm) \\
\hline
\end{tabular}

Gladstone 2011

\begin{tabular}{ll}
\hline Trial name or title & "Spot sign" selection of intracerebral hemorrhage to guide hemostatic therapy (SPOTLIGHT) \\
\hline Methods & Double-blind, placebo-controlled RCT \\
\hline Participants & $\begin{array}{l}\text { Patients with ICH not due to trauma or other known causes with "spot sign" on CT angiography (sign of } \\
\text { active bleeding) who can be treated within } 6 \text { hours of onset } \\
\text { Estimated enrolment: } 110\end{array}$ \\
\hline Interventions & Recombinant FVIIa \\
\hline Outcomes & Primary outcome: ICH size at 24 hours \\
\hline Starting date & May 2011 to August 2016
\end{tabular}


Gladstone 2011 (Continued)

\begin{tabular}{ll}
\hline Contact information & $\begin{array}{l}\text { David J Gladstone, MD } \\
\text { 416-480-4866 } \\
\text { david.gladstone@sunnybrook.ca }\end{array}$ \\
\hline Notes & Recruiting \\
\hline
\end{tabular}

Gris 2006

Trial name or title rFVIIa as salvage therapy in severe post-partum haemorrhage

\begin{tabular}{|c|c|}
\hline Methods & - \\
\hline Participants & $\begin{array}{l}\text { Female patients with post-partum haemorrhage responding to none of the existing medical and surgical } \\
\text { treatments }\end{array}$ \\
\hline Interventions & Recombinant human activated FVII (rhuFVIIa) \\
\hline Outcomes & $\begin{array}{l}\text { Primary outcomes: } \\
\text { Clinical parameters: intensity of haemorrhage before and } 1 \text { hour after administration of rhuFVIIa; number } \\
\text { of units and volume of RBC, platelets, FFP; haemodynamics-related parameters }\end{array}$ \\
\hline Starting date & December 2006 to December 2009 \\
\hline Contact information & $\begin{array}{l}\text { Geraldine Lissalde-Lavigne MD, PhD } \\
\text { geraldine.lavigne@chu-nimes.fr } \\
\text { +33466683211 }\end{array}$ \\
\hline Notes & Recruitment status is unknown \\
\hline
\end{tabular}

Imberti 2005

\begin{tabular}{ll} 
Trial name or title & $\begin{array}{l}\text { Efficacy and safety of rFVIIa on rebleeding after surgery for spontaneous supratentorial intracerebral haem- } \\
\text { orrhage: a randomised controlled open label investigator blinded pilot study }\end{array}$ \\
\hline Methods & - \\
\hline Participants & $\begin{array}{l}\text { Patients receiving surgery for spontaneous supratentorial intracerebral haemorrhage } \\
\text { Estimated enrolment: } 30\end{array}$ \\
\hline Interventions & rFVIIa (Eptacog alfa, Novo Nordisk) \\
\hline Outcomes & $\begin{array}{l}\text { Primary outcome: } \\
\text { Evaluate the efficacy of Factor VIIa (Eptacog alfa) in preventing or reducing rebleeding after surgery for } \\
\text { spontaneous supratentorial ICH } \\
\text { Secondary outcomes: } \\
\text { Safety of product administration }\end{array}$
\end{tabular}




\section{Imberti 2005 (Continued)}

\begin{tabular}{ll}
\hline Starting date & January 2005 to December 2008 \\
\hline Contact information & $\begin{array}{l}\text { Roberto Imberti M.D., Principal Investigator, IRCCS Policlinico S. Matteo - Pavia - Italy } \\
\text { Roberto Imberti M.D. } \\
\text { Tel: }+390382502071 \\
\text { r.imberti@smatteo.pv.it }\end{array}$ \\
\hline Notes & Completed. Not yet published. \\
\hline
\end{tabular}

Iorio 2006

Trial name or title Randomised, open, prospective, multicenter pilot study to evaluate the efficacy and safety of activated recombinant factor VII in acute intracerebral haemorrhage in patients treated with oral anticoagulants or antiplatelet agents

\begin{tabular}{|c|c|}
\hline Methods & - \\
\hline Participants & $\begin{array}{l}\text { Acute intracerebral haemorrhage in adult patients on treatment with one of the following: } \\
\text { a) oral anticoagulant } \\
\text { b) aspirin, whatever dosage } \\
\text { Estimated enrolment: } 32\end{array}$ \\
\hline Interventions & rFVIIa \\
\hline Outcomes & $\begin{array}{l}\text { Primary outcomes: } \\
\text { EFFICACY: change in ICH volume from prior to dosing to } 24 \text { hours } \\
\text { SAFETY: occurrence of clinical adverse events (thromboembolic events, death) } \\
\text { Secondary outcomes: } \\
\text { Difference between groups on the modified Rankin Scale, the Barthel Index (BI), the Extended Glasgow } \\
\text { Scale (EGCS), and the National Institute of Health's Stroke Scale (NIHSS) at } 1 \text { and 3-month follow-up }\end{array}$ \\
\hline Starting date & September 2005 to September 2006 \\
\hline Contact information & $\begin{array}{l}\text { Alfonso Iorio, Principal Investigator, University Of Perugia } \\
\text { Tel: +39075 } 5784306 \\
\text { iorioa@unipg.it }\end{array}$ \\
\hline Notes & Recruitment status is unknown \\
\hline
\end{tabular}

Kelleher 2006

Trial name or title A multi-centre, randomised, double-blind, placebo-controlled, dose-escalation trial of safety and efficacy of activated recombinant factor VII (Rfv1 1a/NovoSeven) in the treatment of post-operative bleeding in patients following cardiac surgery requiring cardiopulmonary bypass

Methods 
Kelleher 2006 (Continued)

\begin{tabular}{ll}
\hline Participants & Patients post-cardiac surgery \\
\hline Interventions & rFVIIa (NovoSeven $囚)$ \\
\hline Outcomes & $\begin{array}{l}\text { Outcome measures: } \\
\text { Critical serious adverse events: death, acute myocardial infarction, cerebral infarction }\end{array}$ \\
\hline Starting date & 2006 \\
\hline Contact information & $\begin{array}{l}\text { Dr Andrea Kelleher, Royal Brompton and Harefield NHS Trust, London SW3 6NP } \\
\text { A.Kelleher@rbh.nthames.nhs.uk }\end{array}$ \\
\hline Notes & Completed. Not yet published. \\
\hline
\end{tabular}

\section{McCall 2005}

Trial name or title "Salvage use" of rFVIIa after inadequate haemostatic response to conventional therapy in complex cardiac surgery - a randomised placebo-controlled trial

\begin{tabular}{|c|c|}
\hline Methods & - \\
\hline Participants & $\begin{array}{l}\text { Adult patients with scheduled cardiac surgery undergoing the following procedures: } \\
\text { - double valve replacements or repair } \\
\text { - major thoracic aortic surgery including hypothermic circulatory arrest or descending aortic reconstruction } \\
\text { - valve repair or replacement in the setting of endocarditis } \\
\text { - complex procedures requiring cardiopulmonary bypass duration anticipated to exceed } 180 \text { minutes in } \\
\text { patients aged } 70 \text { years } \\
\text { Expected enrolment: } 40\end{array}$ \\
\hline Interventions & rFVIIa \\
\hline Outcomes & $\begin{array}{l}\text { Primary outcome: } \\
\text { Adequate haemostasis to enable chest closure after administration of trial medication without the need for } \\
\text { further intervention to improve coagulation } \\
\text { Secondary outcomes: } \\
\text { Percentage of cases that haemostasis after first administration of coagulation factors alone; assessment of } \\
\text { surgical field after administration of trial medication; time to closure of chest after administration of trial } \\
\text { medication; transfusion requirements in post-bypass period in theatre; transfusion requirements in ICU first } \\
12 \text { hours; mediastinal drainage in ICU first } 12 \text { hours; coagulation study results at various sample times; } \\
\text { requirement for chest re-exploration; ventilation duration in ICU; duration of stay in ICU }\end{array}$ \\
\hline Starting date & June 2005 to June 2008 \\
\hline Contact information & $\begin{array}{l}\text { Austin Health } \\
\text { Melbourne } \\
\text { Victoria } \\
3084 \\
\text { Contact: Peter McCall FANZCA }\end{array}$ \\
\hline
\end{tabular}

Recombinant factor VIla for the prevention and treatment of bleeding in patients without haemophilia (Review)

Copyright @ 2012 The Cochrane Collaboration. Published by John Wiley \& Sons, Ltd. 
McCall 2005

Tel: +61 394965000 ext.: 3800

peter.mccall@austin.org.au

Contact backup: Stephanie J Poustie MPH

Tel: +61 394965000 ext.: 3800

stephanie.poustie@austin.org.au

Investigator: Peter McCall FANZCA, Principal Investigator

Notes

Recruitment status is unknown.

Molter 2005

Trial name or title Effect of rFVIIa on peri-operative blood loss in patients undergoing major burn excision and grafting: a randomised, double-blind, placebo-controlled parallel assignment efficacy study

\begin{tabular}{ll}
\hline Methods & - \\
\hline Participants & $\begin{array}{l}\text { Patients undergoing major burn excision and grafting } \\
\text { Estimated enrolment: } 52\end{array}$ \\
\hline Interventions & rFVIIa \\
\hline Outcomes & Reduce perioperative blood loss and transfusion requirements \\
\hline Starting date & January 2006 to December 2010 \\
\hline Contact information & $\begin{array}{l}\text { Nancy C Molter RN, PhD } \\
\text { Tel: } 210 \text { 916 5690 } \\
\text { Nancy.Molter@amedd.army.mil }\end{array}$ \\
\hline Notes & Active, but not recruiting \\
\hline
\end{tabular}

$\mathrm{Ng} 2006$

\begin{tabular}{ll} 
Trial name or title & Use of rFVIIa in bleeding ECMO patients post cardiac surgery. Randomised prospective study \\
\hline Methods & - \\
\hline Participants & Patients post-cardiac surgery \\
\hline Interventions & rFVIIa \\
\hline
\end{tabular}

Outcomes $\quad$ a) Amount of postoperative bleeding

b) Use of human blood products

Starting date April 2004 


\section{$\mathrm{Ng} 2006$ (Continued)}

\section{Contact information $\mathrm{MrC} \mathrm{Ng}$}

PICU, Great Ormond Street Hospital, Great Ormond Street, London, WC1N 3JH, UK

Tel: +4402074059200

Notes

Recruitment status is unknown

$\mathrm{CT}=$ computerised tomography

$\mathrm{FFP}=$ fresh frozen plasma

HSCT $=$ haematopoietic stem cell transplantation

$\mathrm{ICH}=$ intracranial haemorrhage

ICU $=$ intensive care unit

iv $=$ intravenous

$\mathrm{IVH}=$ intraventriculare hemorrhage

$\mathrm{RBC}=$ red blood cell

$\mathrm{RCT}=$ randomised controlled trial

rFVIIa = recombinant factor VIIa 
DATA ANDANALYSES

Comparison 1. rFVIIa used prophylactically versus placebo

\begin{tabular}{|c|c|c|c|c|}
\hline Outcome or subgroup title & $\begin{array}{l}\text { No. of } \\
\text { studies }\end{array}$ & $\begin{array}{c}\text { No. of } \\
\text { participants }\end{array}$ & Statistical method & Effect size \\
\hline 1 Death & 15 & 1219 & Risk Ratio (M-H, Fixed, 95\% CI) & $1.04[0.55,1.97]$ \\
\hline 2 Death - exploring heterogeneity & 15 & & Risk Ratio (M-H, Fixed, 95\% CI) & Subtotals only \\
\hline $\begin{array}{l}\text { 2.1 Studies with } \geq 50 \text { patients } \\
\text { each }\end{array}$ & 7 & 995 & Risk Ratio (M-H, Fixed, 95\% CI) & $1.36[0.67,2.78]$ \\
\hline $\begin{array}{l}\text { 2.2 Studies with }<50 \text { patients } \\
\text { each }\end{array}$ & 8 & 224 & Risk Ratio (M-H, Fixed, 95\% CI) & $0.2[0.03,1.57]$ \\
\hline $\begin{array}{l}2.3 \text { Studies with adequate } \\
\text { allocation concealment }\end{array}$ & 3 & 408 & Risk Ratio (M-H, Fixed, 95\% CI) & $1.21[0.51,2.89]$ \\
\hline $\begin{array}{l}2.4 \text { Studies with transfusion } \\
\text { protocols }\end{array}$ & 13 & 1121 & Risk Ratio (M-H, Fixed, 95\% CI) & $1.04[0.55,1.97]$ \\
\hline $\begin{array}{l}3 \text { Total operative and perioperative } \\
\text { blood loss }(\mathrm{mL})\end{array}$ & 10 & 707 & Mean Difference (IV, Random, 95\% CI) & $\begin{array}{l}-296.97[-416.32,- \\
177.61]\end{array}$ \\
\hline $\begin{array}{l}4 \text { Total operative and perioperative } \\
\text { blood loss }(\mathrm{mL}) \text { - exploring } \\
\text { heterogeneity }\end{array}$ & 10 & & Mean Difference (IV, Random, 95\% CI) & Subtotals only \\
\hline $\begin{array}{l}\text { 4.1 Studies with } \geq 50 \text { patients } \\
\text { each }\end{array}$ & 4 & 549 & Mean Difference (IV, Random, 95\% CI) & $\begin{array}{l}-261.01[-550.32 \\
28.29]\end{array}$ \\
\hline $\begin{array}{l}\text { 4.2 Studies with }<50 \text { patients } \\
\text { each }\end{array}$ & 6 & 158 & Mean Difference (IV, Random, 95\% CI) & $\begin{array}{l}-304.87[-439.60,- \\
170.15]\end{array}$ \\
\hline $\begin{array}{l}4.3 \text { Studies with adequate } \\
\text { allocation concealment }\end{array}$ & 3 & 393 & Mean Difference (IV, Random, 95\% CI) & $\begin{array}{l}-604.91[-1259.77 \\
49.95]\end{array}$ \\
\hline $\begin{array}{l}4.4 \text { Studies with transfusion } \\
\text { protocols }\end{array}$ & 9 & 685 & Mean Difference (IV, Random, 95\% CI) & $\begin{array}{l}-342.30[-479.01,- \\
205.60]\end{array}$ \\
\hline $\begin{array}{l}5 \text { Red cell transfusion requirements } \\
(\mathrm{mL})\end{array}$ & 12 & 843 & Mean Difference (IV, Random, 95\% CI) & $\begin{array}{l}-260.78[-367.30,- \\
154.27]\end{array}$ \\
\hline $\begin{array}{l}6 \text { Red cell transfusion requirements } \\
\text { - exploring heterogeneity }\end{array}$ & 12 & & Mean Difference (IV, Random, 95\% CI) & Subtotals only \\
\hline $\begin{array}{l}\text { 6.1 Studies with } \geq 50 \text { patients } \\
\text { each }\end{array}$ & 4 & 618 & Mean Difference (IV, Random, 95\% CI) & $\begin{array}{l}-33.42[-260.27 \\
193.43]\end{array}$ \\
\hline $\begin{array}{l}\text { 6.2 Studies with }<50 \text { patients } \\
\text { each }\end{array}$ & 8 & 225 & Mean Difference (IV, Random, 95\% CI) & $\begin{array}{l}-310.57[-413.14,- \\
208.00]\end{array}$ \\
\hline $\begin{array}{l}\text { 6.3 Studies with adequate } \\
\text { allocation concealment }\end{array}$ & 3 & 393 & Mean Difference (IV, Random, 95\% CI) & $\begin{array}{l}-157.57[-478.84 \\
163.70]\end{array}$ \\
\hline $\begin{array}{l}6.4 \text { Studies with transfusion } \\
\text { protocols }\end{array}$ & 11 & 821 & Mean Difference (IV, Random, 95\% CI) & $\begin{array}{l}-248.42[-353.13,- \\
143.70]\end{array}$ \\
\hline 7 Numbers of patients transfused & 8 & 868 & Risk Ratio (M-H, Random, 95\% CI) & $0.85[0.72,1.01]$ \\
\hline $\begin{array}{l}8 \text { Numbers of patients transfused - } \\
\text { exploring heterogeneity }\end{array}$ & 8 & & Risk Ratio (M-H, Random, 95\% CI) & Subtotals only \\
\hline $\begin{array}{l}\text { 8.1 Studies with } \geq 50 \text { patients } \\
\text { each }\end{array}$ & 5 & 764 & Risk Ratio (M-H, Random, 95\% CI) & $0.92[0.86,0.97]$ \\
\hline $\begin{array}{l}\text { 8.2 Studies with }<50 \text { patients } \\
\text { each }\end{array}$ & 3 & 104 & Risk Ratio (M-H, Random, 95\% CI) & $0.44[0.22,0.89]$ \\
\hline
\end{tabular}

Recombinant factor VIla for the prevention and treatment of bleeding in patients without haemophilia (Review)

Copyright $\odot 2012$ The Cochrane Collaboration. Published by John Wiley \& Sons, Ltd. 


\begin{tabular}{|c|c|c|c|c|}
\hline $\begin{array}{l}\text { 8.3 Studies with adequate } \\
\text { allocation concealment }\end{array}$ & 3 & 324 & Risk Ratio (M-H, Random, 95\% CI) & $0.71[0.45,1.10]$ \\
\hline $\begin{array}{l}8.4 \text { Studies with transfusion } \\
\text { protocols }\end{array}$ & 7 & 792 & Risk Ratio (M-H, Random, 95\% CI) & $0.82[0.66,1.01]$ \\
\hline 9 Total thromboembolic events & 13 & 1159 & Risk Ratio (M-H, Random, 95\% CI) & $1.35[0.82,2.25]$ \\
\hline $\begin{array}{l}10 \text { Total thromboembolic events - } \\
\text { exploring heterogeneity }\end{array}$ & 13 & & Risk Ratio (M-H, Random, 95\% CI) & Subtotals only \\
\hline $\begin{array}{l}10.1 \text { Studies with } \geq 50 \\
\text { patients each }\end{array}$ & 7 & 995 & Risk Ratio (M-H, Random, 95\% CI) & $1.39[0.81,2.37]$ \\
\hline $\begin{array}{l}\text { 10.2 Studies with }<50 \\
\text { patients each }\end{array}$ & 6 & 164 & Risk Ratio (M-H, Random, 95\% CI) & $1.11[0.24,5.13]$ \\
\hline
\end{tabular}

Comparison 2. rFVIIa used therapeutically versus placebo

\begin{tabular}{|c|c|c|c|c|}
\hline Outcome or subgroup title & $\begin{array}{l}\text { No. of } \\
\text { studies }\end{array}$ & $\begin{array}{c}\text { No. of } \\
\text { participants }\end{array}$ & Statistical method & Effect size \\
\hline 1 Death & 13 & 2856 & Risk Ratio (M-H, Random, 95\% CI) & $0.91[0.78,1.06]$ \\
\hline 2 Death - exploring heterogeneity & 13 & & Risk Ratio (M-H, Random, 95\% CI) & Subtotals only \\
\hline $\begin{array}{l}\text { 2.1 Studies with } \geq 50 \text { patients } \\
\text { each }\end{array}$ & 10 & 2744 & Risk Ratio (M-H, Random, 95\% CI) & $0.91[0.78,1.07]$ \\
\hline $\begin{array}{l}2.2 \text { Studies with }<50 \text { patients } \\
\text { each }\end{array}$ & 3 & 112 & Risk Ratio (M-H, Random, 95\% CI) & $0.81[0.22,3.03]$ \\
\hline $\begin{array}{l}2.3 \text { Studies with adequate } \\
\text { concealment allocation }\end{array}$ & 6 & 1545 & Risk Ratio (M-H, Random, 95\% CI) & $0.90[0.69,1.16]$ \\
\hline $\begin{array}{l}2.4 \text { Studies with transfusion } \\
\text { protocols }\end{array}$ & 5 & 1146 & Risk Ratio (M-H, Random, 95\% CI) & $1.00[0.77,1.30]$ \\
\hline $\begin{array}{l}2.5 \text { Studies without } \\
\text { transfusion protocols }\end{array}$ & 8 & 1704 & Risk Ratio (M-H, Random, 95\% CI) & $0.86[0.71,1.05]$ \\
\hline $\begin{array}{l}3 \text { Control of bleeding (number of } \\
\text { patients with reduced bleeding) }\end{array}$ & 4 & 616 & Risk Ratio (M-H, Random, 95\% CI) & $0.95[0.88,1.03]$ \\
\hline $\begin{array}{l}4 \text { Control of bleeding - exploring } \\
\text { heterogeneity }\end{array}$ & 3 & & Risk Ratio (M-H, Random, 95\% CI) & Subtotals only \\
\hline $\begin{array}{l}\text { 4.1 Studies with } \geq 50 \text { patients } \\
\text { each }\end{array}$ & 3 & 571 & Risk Ratio (M-H, Random, 95\% CI) & $0.95[0.88,1.03]$ \\
\hline $\begin{array}{l}5 \text { Red cell transfusion requirements } \\
\quad(\mathrm{mL})\end{array}$ & 5 & 911 & Mean Difference (IV, Random, 95\% CI) & $\begin{array}{l}-88.60[-263.88,86 . \\
68]\end{array}$ \\
\hline $\begin{array}{l}6 \text { Red cell transfusion requirements } \\
\quad(\mathrm{mL}) \text { - exploring heterogeneity }\end{array}$ & 4 & & Mean Difference (IV, Random, 95\% CI) & Subtotals only \\
\hline $\begin{array}{l}\text { 6.1 Studies with } \geq 50 \text { patients } \\
\text { each }\end{array}$ & 4 & 886 & Mean Difference (IV, Random, 95\% CI) & $\begin{array}{l}-131.20[-360.09 \\
97.69]\end{array}$ \\
\hline 7 Number of patients transfused & 3 & 585 & Risk Ratio (M-H, Random, 95\% CI) & $0.94[0.88,1.00]$ \\
\hline 8 Total thromboembolic events & 13 & 2873 & Risk Ratio (M-H, Random, 95\% CI) & $1.14[0.89,1.47]$ \\
\hline $\begin{array}{l}9 \text { Total thromboembolic events - } \\
\text { exploring heterogeneity }\end{array}$ & 13 & & Risk Ratio (M-H, Random, 95\% CI) & Subtotals only \\
\hline $\begin{array}{l}\text { 9.1 Studies with } \geq 50 \text { patients } \\
\text { each }\end{array}$ & 10 & 2761 & Risk Ratio (M-H, Random, 95\% CI) & $1.18[0.91,1.54]$ \\
\hline
\end{tabular}

Recombinant factor VIla for the prevention and treatment of bleeding in patients without haemophilia (Review) 


$\begin{array}{lcclc}\begin{array}{l}\text { 9.2 Studies with }<50 \text { patients } \\ \text { each }\end{array} & 3 & 112 & \text { Risk Ratio (M-H, Random, 95\% CI) } & 0.73[0.27,1.92] \\ \begin{array}{l}9.3 \text { Studies with adequate } \\ \text { allocation concealment }\end{array} & 6 & 1566 & \text { Risk Ratio (M-H, Random, 95\% CI) } & 1.11[0.70,1.76] \\ \begin{array}{l}\text { 9.4 Studies with transfusion } \\ \text { protocols }\end{array} & 5 & 1167 & \text { Risk Ratio (M-H, Random, 95\% CI) } & 1.06[0.74,1.52] \\ \end{array}$

Comparison 3. rFVIIa used prophylactically or therapeutically versus placebo (adverse events)

\begin{tabular}{lccll} 
Outcome or subgroup title & $\begin{array}{c}\text { No. of } \\
\text { studies }\end{array}$ & $\begin{array}{c}\text { No. of } \\
\text { participants }\end{array}$ & Statistical method & Effect size \\
\hline 1 Total thromboembolic events & 26 & 4032 & Risk Ratio (M-H, Random, 95\% CI) & $1.18[0.94,1.48]$ \\
$\begin{array}{l}\text { 2 Cardiovascular events, including } \\
\quad\end{array}$ & 24 & 3472 & Risk Ratio (M-H, Random, 95\% CI) & $1.35[0.85,2.15]$ \\
$\begin{array}{l}\text { myocardial infarction } \\
\text { Stroke }\end{array}$ & 23 & 3289 & Risk Ratio (M-H, Random, 95\% CI) & $1.49[0.72,3.07]$ \\
4 Total arterial events & 25 & 3849 & Risk Ratio (M-H, Random, 95\% CI) & $1.45[1.02,2.05]$ \\
5 Total venous events & 25 & 3849 & Risk Ratio (M-H, Random, 95\% CI) & $0.92[0.67,1.26]$ \\
\hline
\end{tabular}

\section{Analysis I.I. Comparison I rFVIla used prophylactically versus placebo, Outcome I Death.}

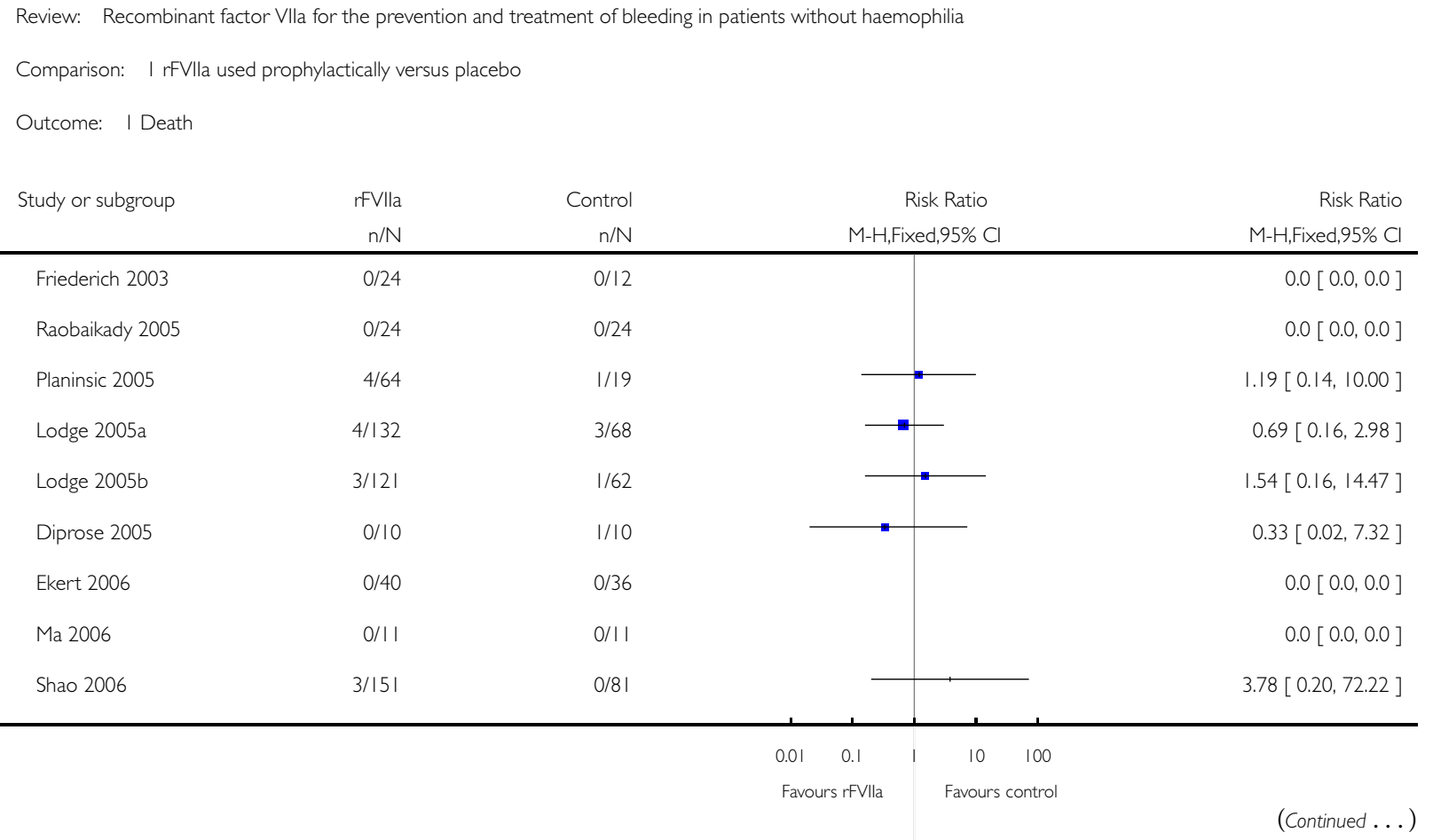




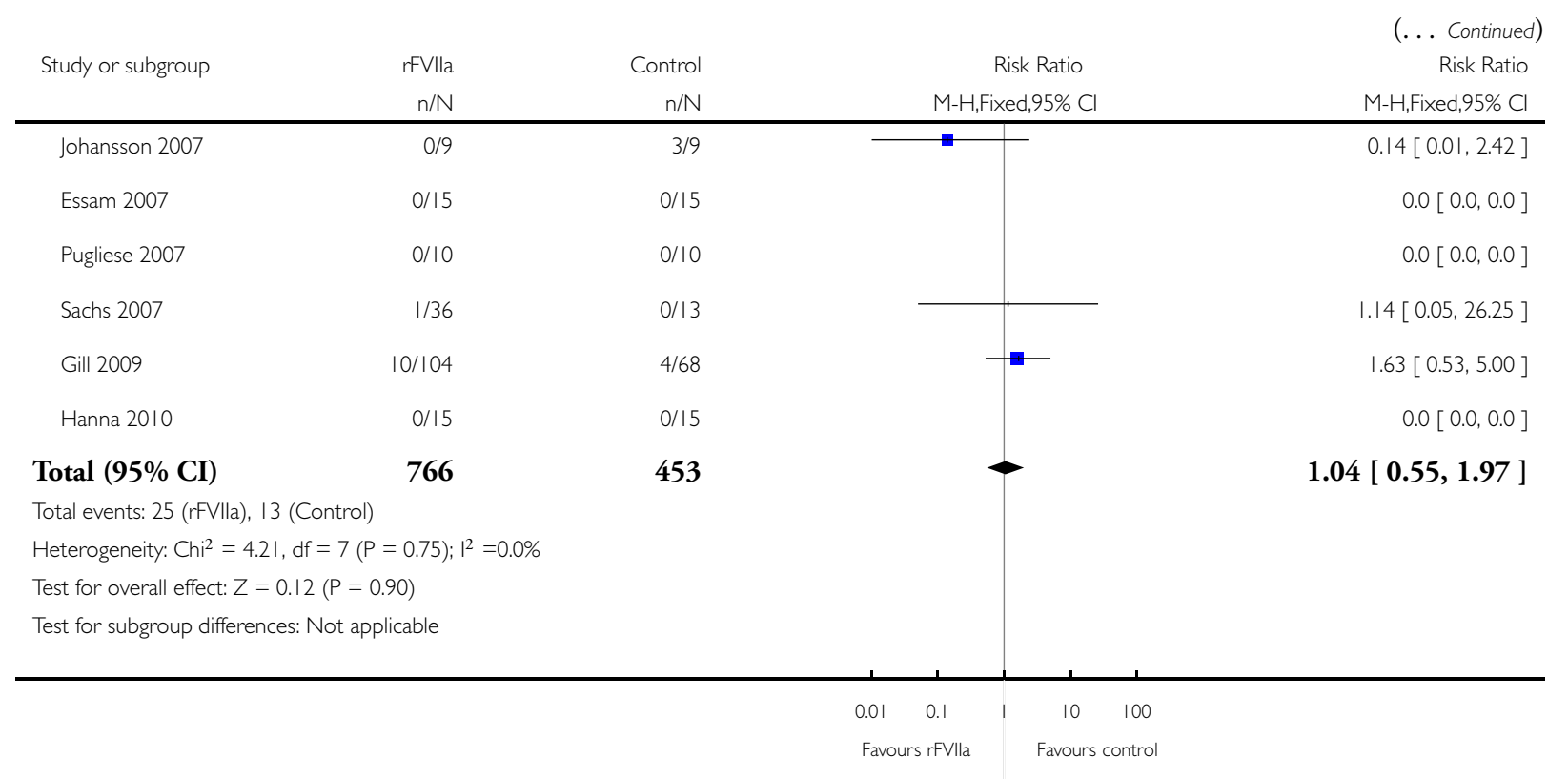




\section{Analysis I.2. Comparison I rFVIla used prophylactically versus placebo, Outcome 2 Death - exploring}

heterogeneity.

Review: Recombinant factor VIla for the prevention and treatment of bleeding in patients without haemophilia

Comparison: I rFVlla used prophylactically versus placebo

Outcome: 2 Death - exploring heterogeneity

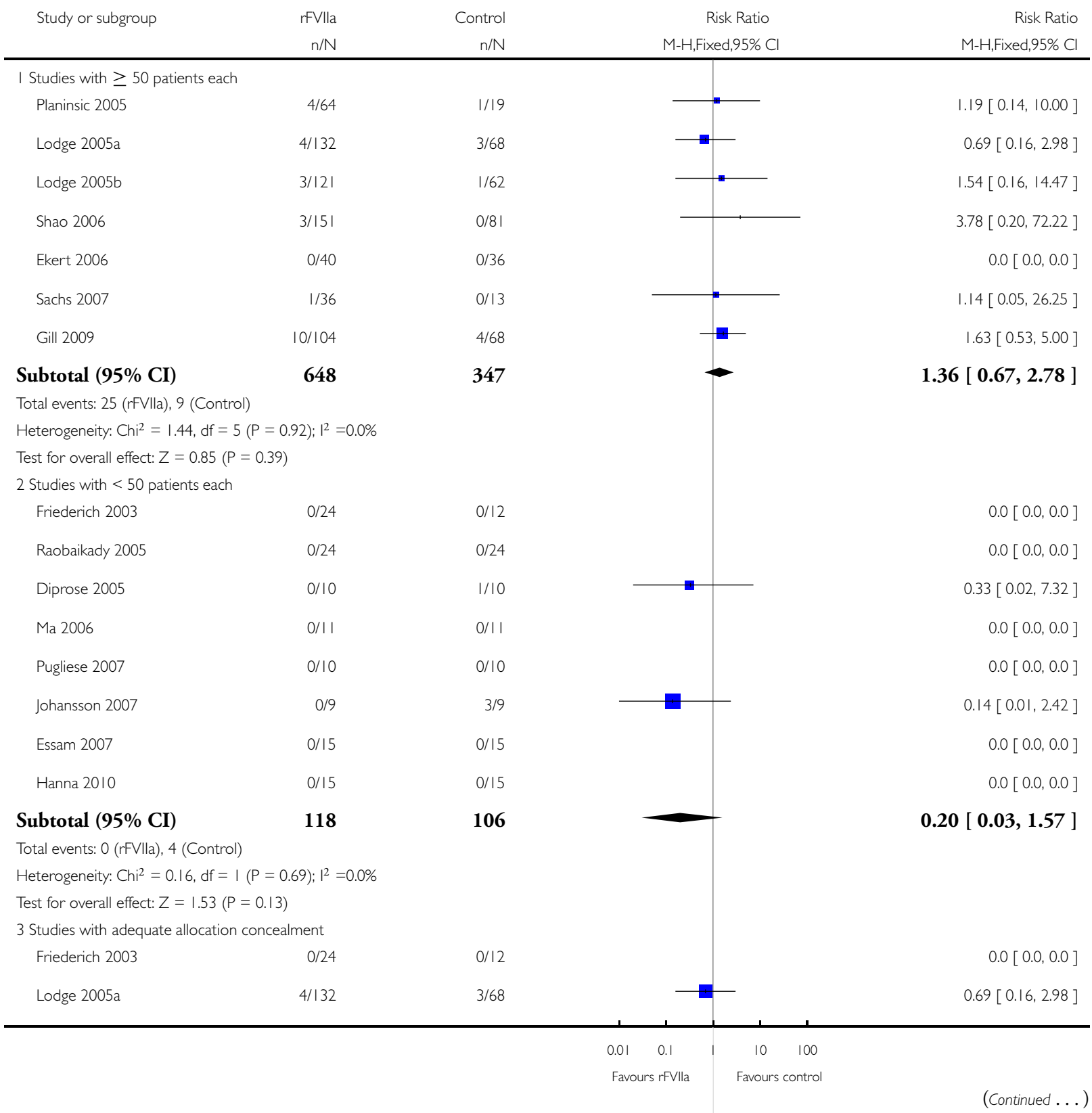




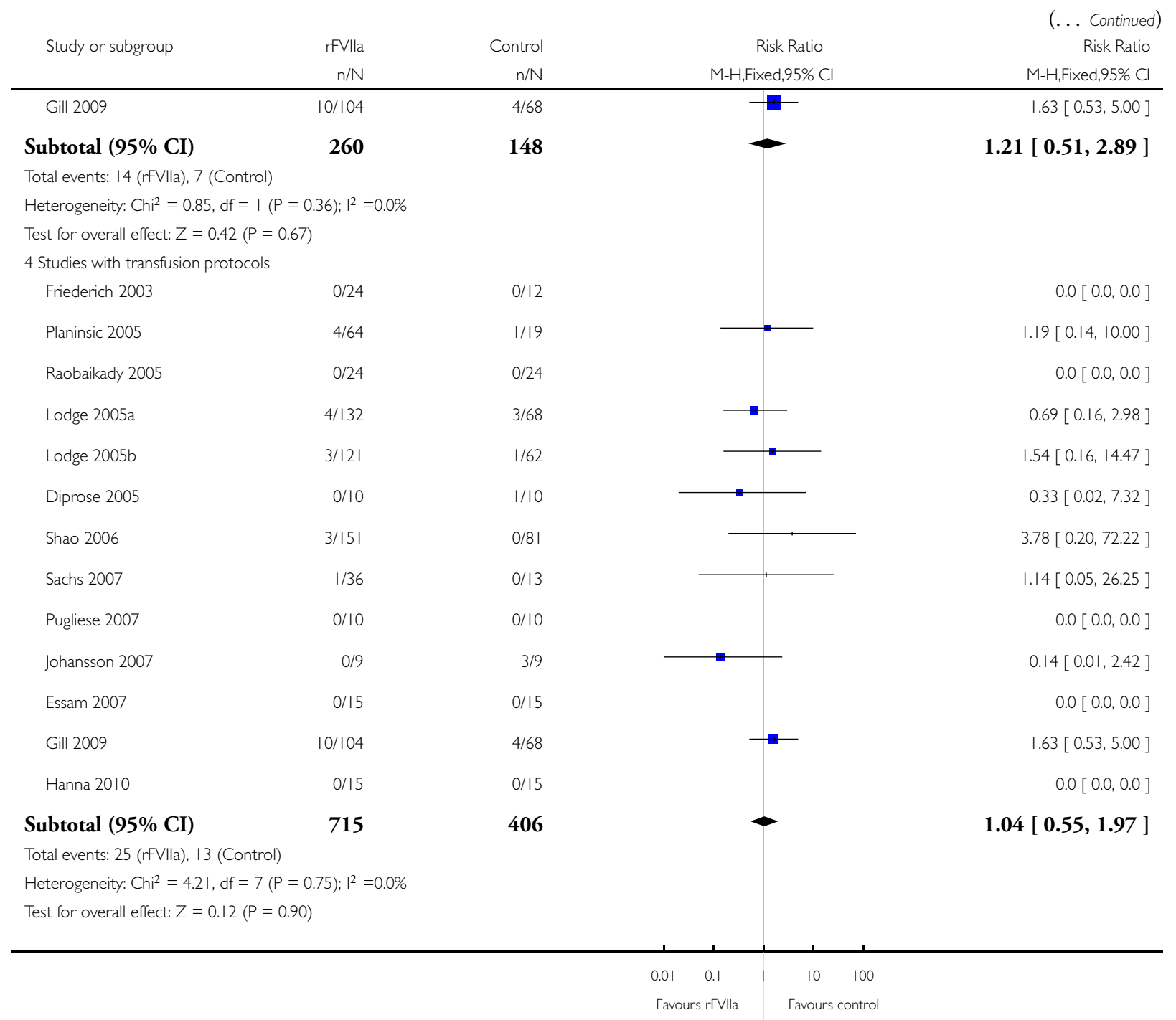


Analysis I.3. Comparison I rFVIla used prophylactically versus placebo, Outcome 3 Total operative and perioperative blood loss $(\mathrm{mL})$.

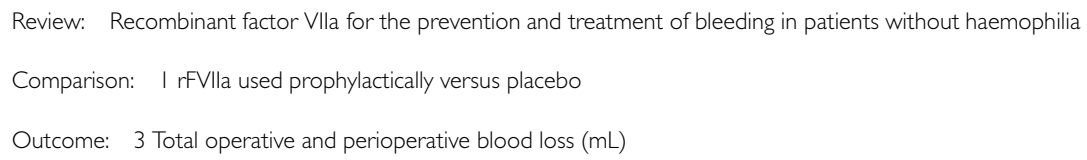




\section{Analysis I.4. Comparison I rFVIla used prophylactically versus placebo, Outcome 4 Total operative and} perioperative blood loss $(\mathrm{mL})$ - exploring heterogeneity.

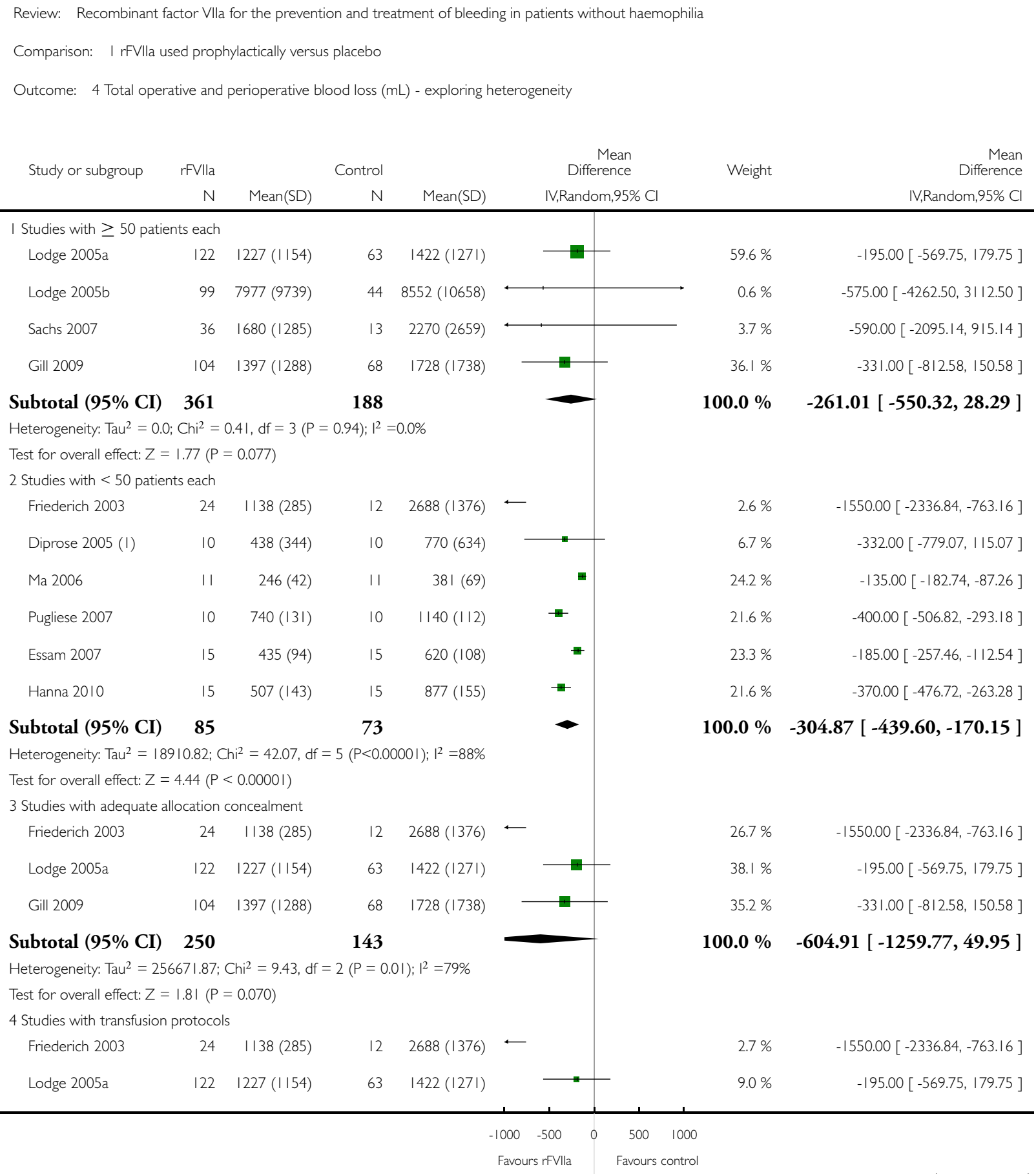

$59.6 \%$

$0.6 \%$

$3.7 \%$

$36.1 \%$

$100.0 \%$

$-261.01[-550.32,28.29$ ]

$2.6 \%$

$6.7 \%$

$24.2 \%$

$21.6 \%$

$23.3 \%$

$21.6 \%$

$100.0 \%$

$$
\begin{aligned}
& -575.00[-4262.50,3112.50] \\
& -590.00[-2095.14,915.14] \\
& -331.00[-812.58,150.58]
\end{aligned}
$$$$
-195.00[-569.75,179.75]
$$

$$
-1550.00[-2336.84,-763.16]
$$$$
-332.00[-779.07,115.07]
$$$$
-135.00[-182.74,-87.26]
$$$$
-400.00[-506.82,-293.18]
$$$$
-185.00[-257.46,-1 \mid 2.54]
$$$$
-370.00[-476.72,-263.28]
$$

$-304.87[-439.60,-170.15]$

$26.7 \% \quad-1550.00[-2336.84,-763.16]$

$38.1 \% \quad-195.00[-569.75,179.75]$

$35.2 \% \quad-331.00[-8 \mid 2.58,150.58]$

$100.0 \% \quad-604.91[-1259.77,49.95$ ]

$\begin{array}{rrrrr}-1000 & -500 & 0 & 500 & 1000 \\ \text { Favours rfVVIla } & \text { Favours control }\end{array}$




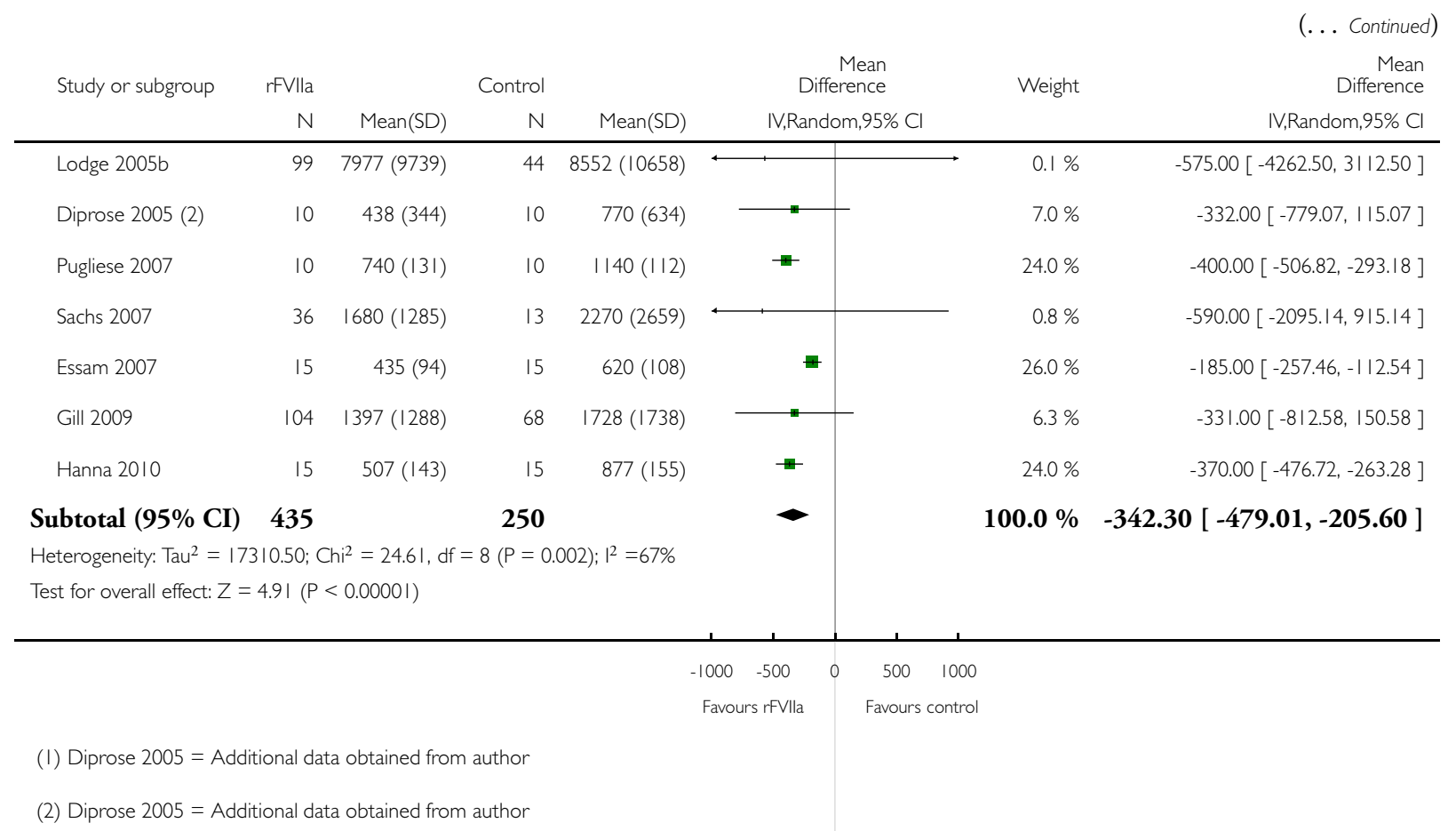




\section{Analysis I.5. Comparison I rFVIla used prophylactically versus placebo, Outcome 5 Red cell transfusion}

requirements $(\mathrm{mL})$.

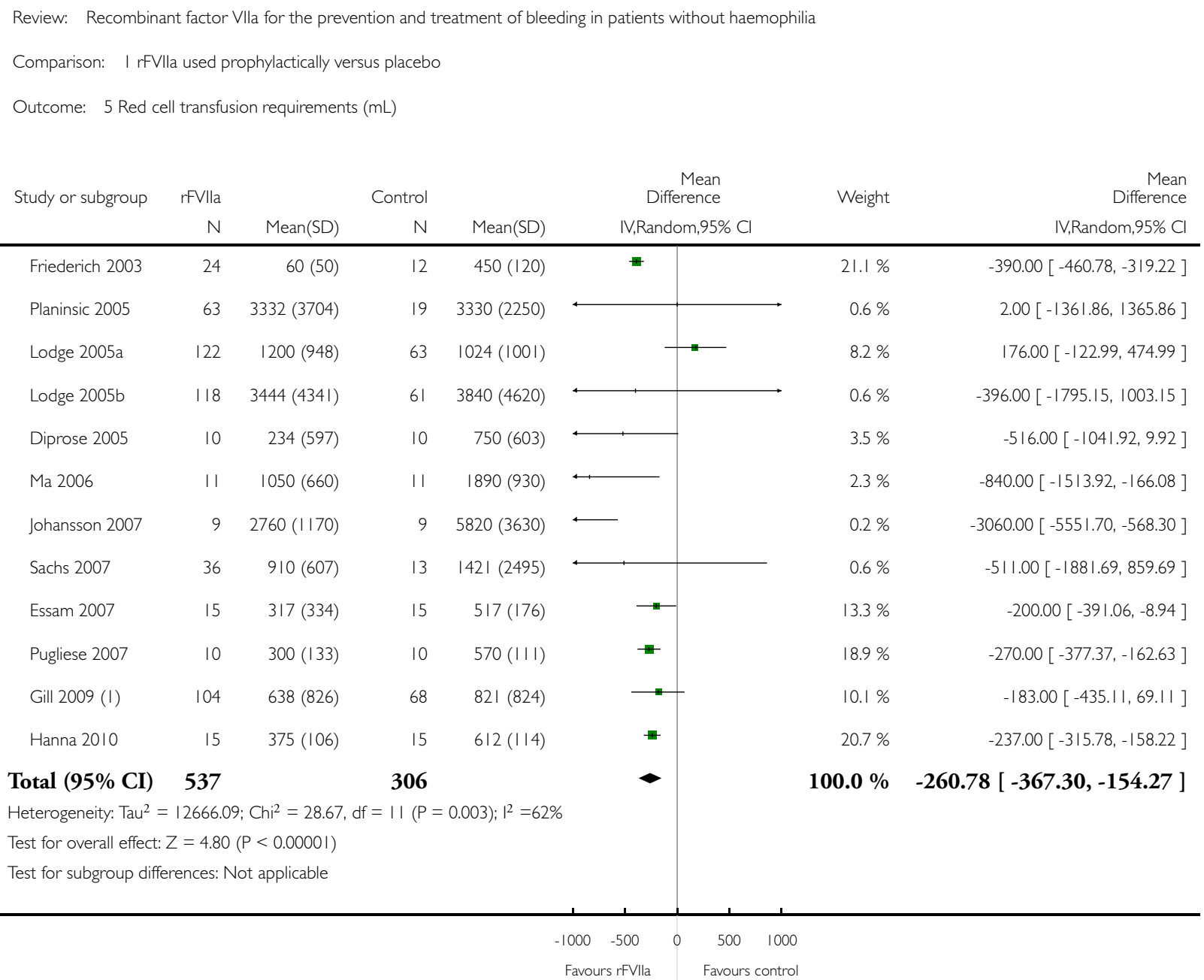

( I) Additional data obtained from author 


\section{Analysis I.6. Comparison I rFVIla used prophylactically versus placebo, Outcome 6 Red cell transfusion requirements - exploring heterogeneity.}

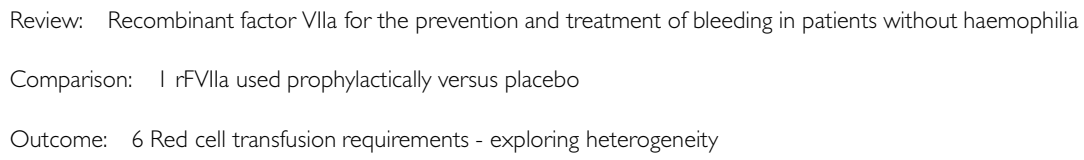

Subtotal (95\% CI) 130

Heterogeneity: $\mathrm{Tau}^{2}=8537.33 ; \mathrm{Chi}^{2}=17.74, \mathrm{df}=7(\mathrm{P}=0.0 \mathrm{I}) ; \mathrm{I}^{2}=61 \%$ Test for overall effect: $Z=5.93(P<0.0000$ I)

3 Studies with adequate allocation concealment

$\begin{array}{lcccc}\text { Friederich 2003 } & 24 & 60(50) & 12 & 450(\text { I20) } \\ \text { Lodge 2005a } & 122 & 1200(948) & 63 & 1024(100 \mid) \\ \text { Gill 2009 (2) } & 104 & 638(826) & 68 & 821(824)\end{array}$

Subtotal (95\% CI) 250

\begin{tabular}{l|lr} 
& & $2.7 \%$ \\
& & $41.8 \%$ \\
$\longrightarrow$ & & $2.6 \%$ \\
& & $52.9 \%$
\end{tabular}

$100.0 \%$

$-33.42[-260.27,193.43]$

Heterogeneity: $\mathrm{Tau}^{2}=67991.37 ; \mathrm{Chi}^{2}=14.80, \mathrm{df}=2(\mathrm{P}=0.0006 \mathrm{I}) ; \mathrm{I}^{2}=86 \%$

Test for overall effect: $Z=0.96(P=0.34)$

4 Studies with transfusion protocols 


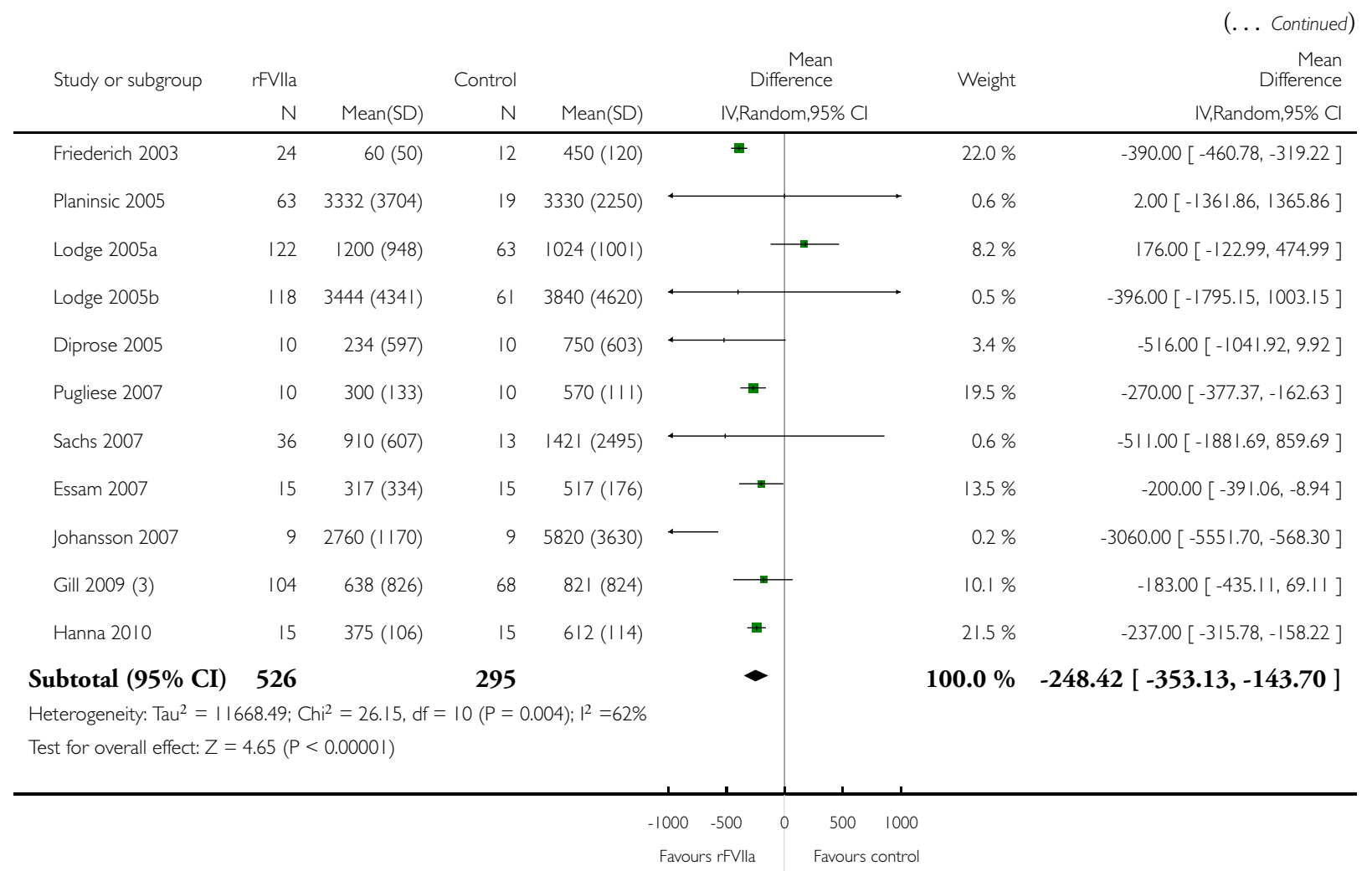

( I) Additional data obtained from author

(2) Additional data obtained from author

(3) Additional data obtained from author 
Analysis I.7. Comparison I rFVIla used prophylactically versus placebo, Outcome 7 Numbers of patients transfused.

Review: Recombinant factor VIla for the prevention and treatment of bleeding in patients without haemophilia

Comparison: I rFVlla used prophylactically versus placebo

Outcome: 7 Numbers of patients transfused

Study or subgroup $\quad$ rFVlla $\quad$ Control Risk Ratio $\quad$ Wisk Ratio H,Random,95\% $\quad H$, Random, $95 \%$

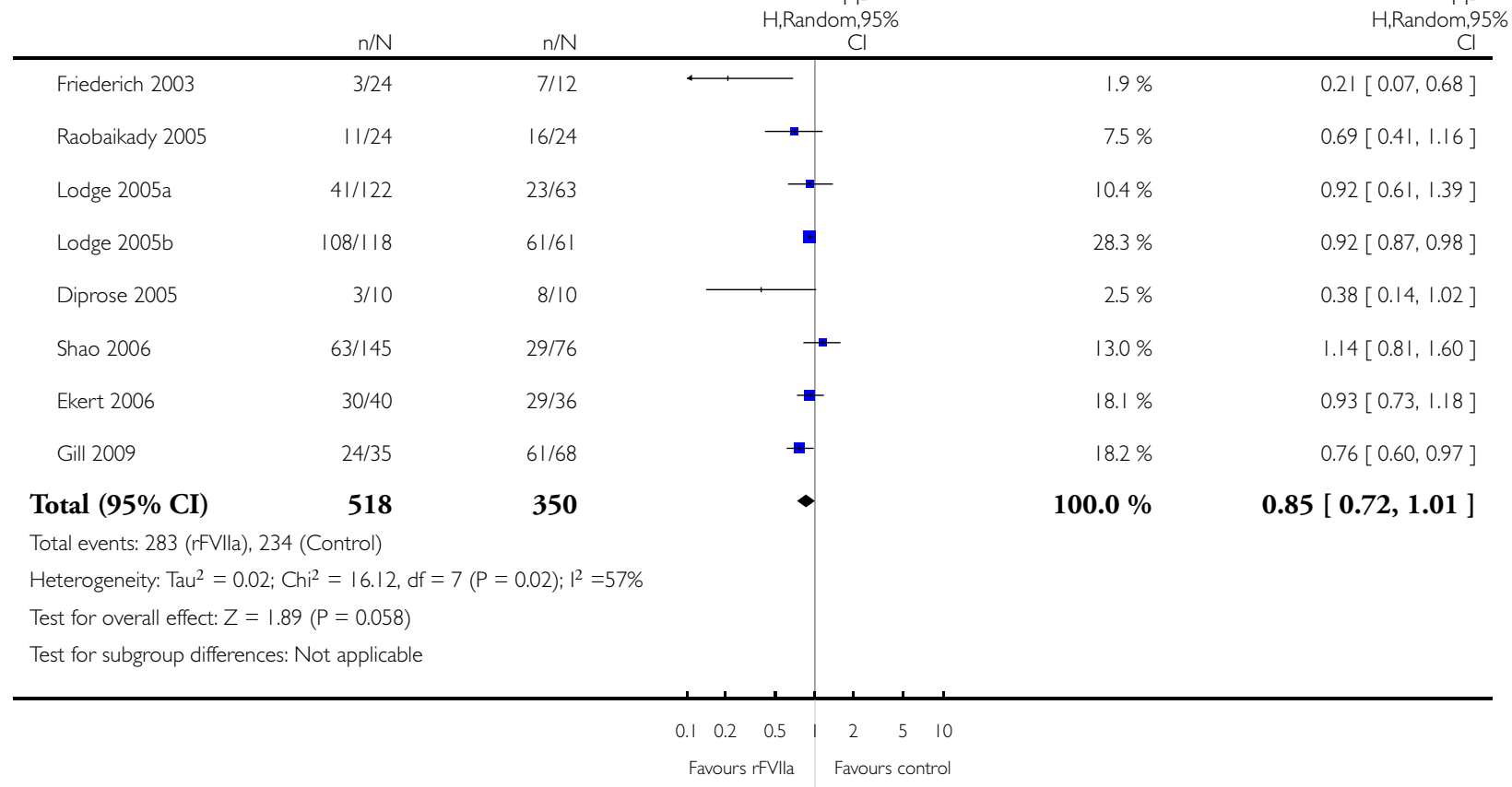




\section{Analysis I.8. Comparison I rFVIla used prophylactically versus placebo, Outcome 8 Numbers of patients}

transfused - exploring heterogeneity.

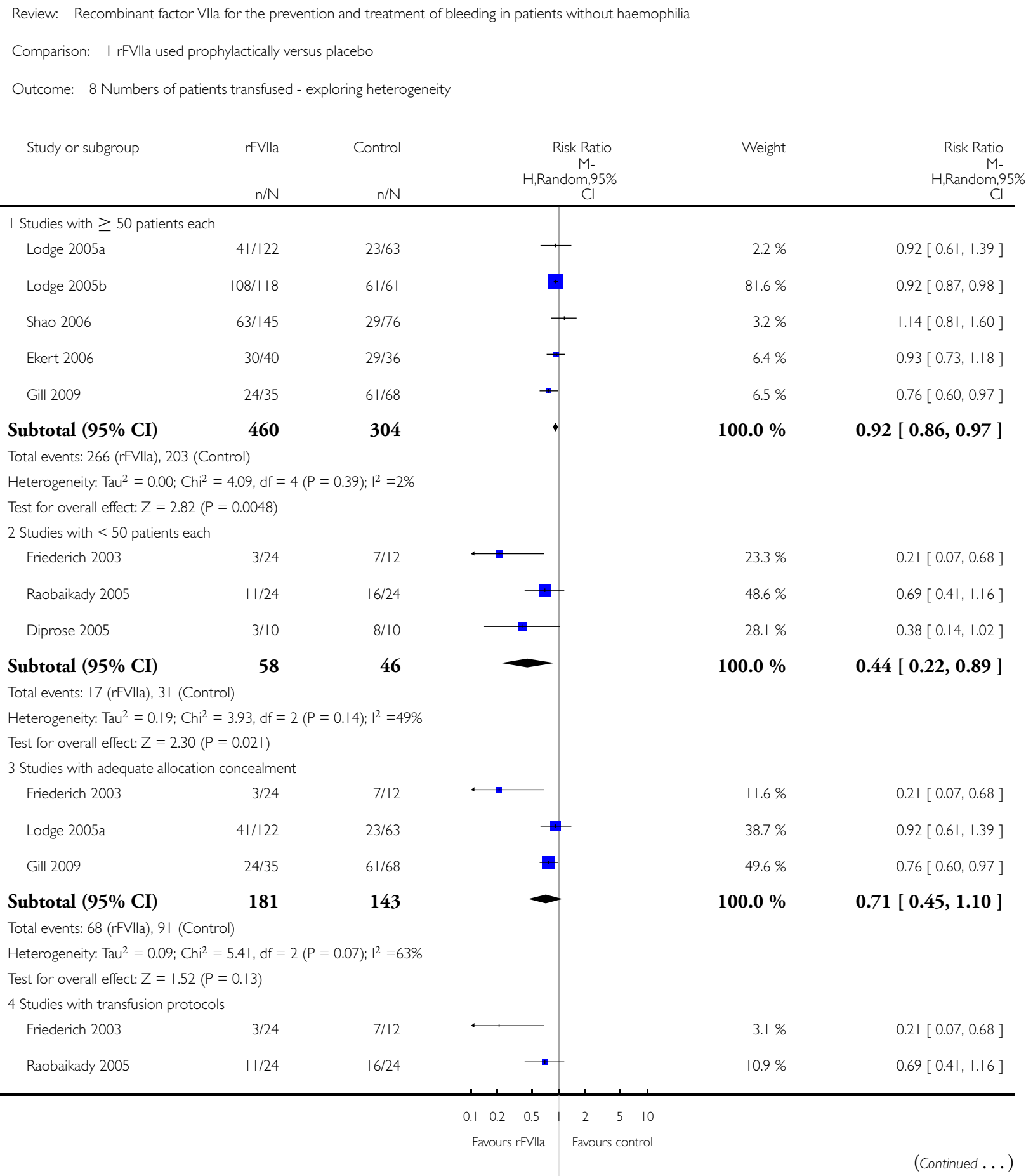




\begin{tabular}{|c|c|c|c|c|c|}
\hline Study or subgroup & $\begin{array}{l}\mathrm{rFVlla} \\
\mathrm{n} / \mathrm{N} \\
\end{array}$ & $\begin{array}{l}\text { Control } \\
n / N \\
\end{array}$ & $\begin{array}{c}\text { Risk Ratio } \\
\text { M- } \\
\text { H,Random,95\% } \\
\text { Cl }\end{array}$ & Weight & $\begin{array}{c}\text { (... Continued) } \\
\text { Risk Ratio } \\
\text { M- } \\
\text { H,Random,95\% } \\
\text { Cl }\end{array}$ \\
\hline Lodge 2005a & $41 / 122$ & $23 / 63$ & $\rightarrow$ & $14.3 \%$ & $0.92[0.61,1.39]$ \\
\hline Lodge 2005b & $108 / 118$ & $61 / 61$ & 证 & $29.0 \%$ & $0.92[0.87,0.98]$ \\
\hline Diprose 2005 & $3 / 10$ & $8 / 10$ & + & $4.0 \%$ & $0.38[0.14,1.02]$ \\
\hline Shao 2006 & $63 / 145$ & $29 / 76$ & - & $17.0 \%$ & $1.14[0.81,1.60]$ \\
\hline Gill 2009 & $24 / 35$ & $61 / 68$ & - & $21.7 \%$ & $0.76[0.60,0.97]$ \\
\hline Subtotal $(95 \% \mathrm{CI})$ & 478 & 314 & 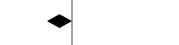 & $100.0 \%$ & $0.82[0.66,1.01]$ \\
\hline \multicolumn{6}{|c|}{ Total events: 253 (rFVlla), 205 (Control) } \\
\hline \multicolumn{6}{|c|}{ Heterogeneity: $\mathrm{Tau}^{2}=0.04 ; \mathrm{Chi}^{2}=16.84, \mathrm{df}=6(\mathrm{P}=0.0 \mathrm{I}) ; \mathrm{I}^{2}=64 \%$} \\
\hline \multicolumn{6}{|c|}{ Test for overall effect: $Z=1.82(P=0.068)$} \\
\hline
\end{tabular}


Analysis I.9. Comparison I rFVIla used prophylactically versus placebo, Outcome 9 Total thromboembolic events.

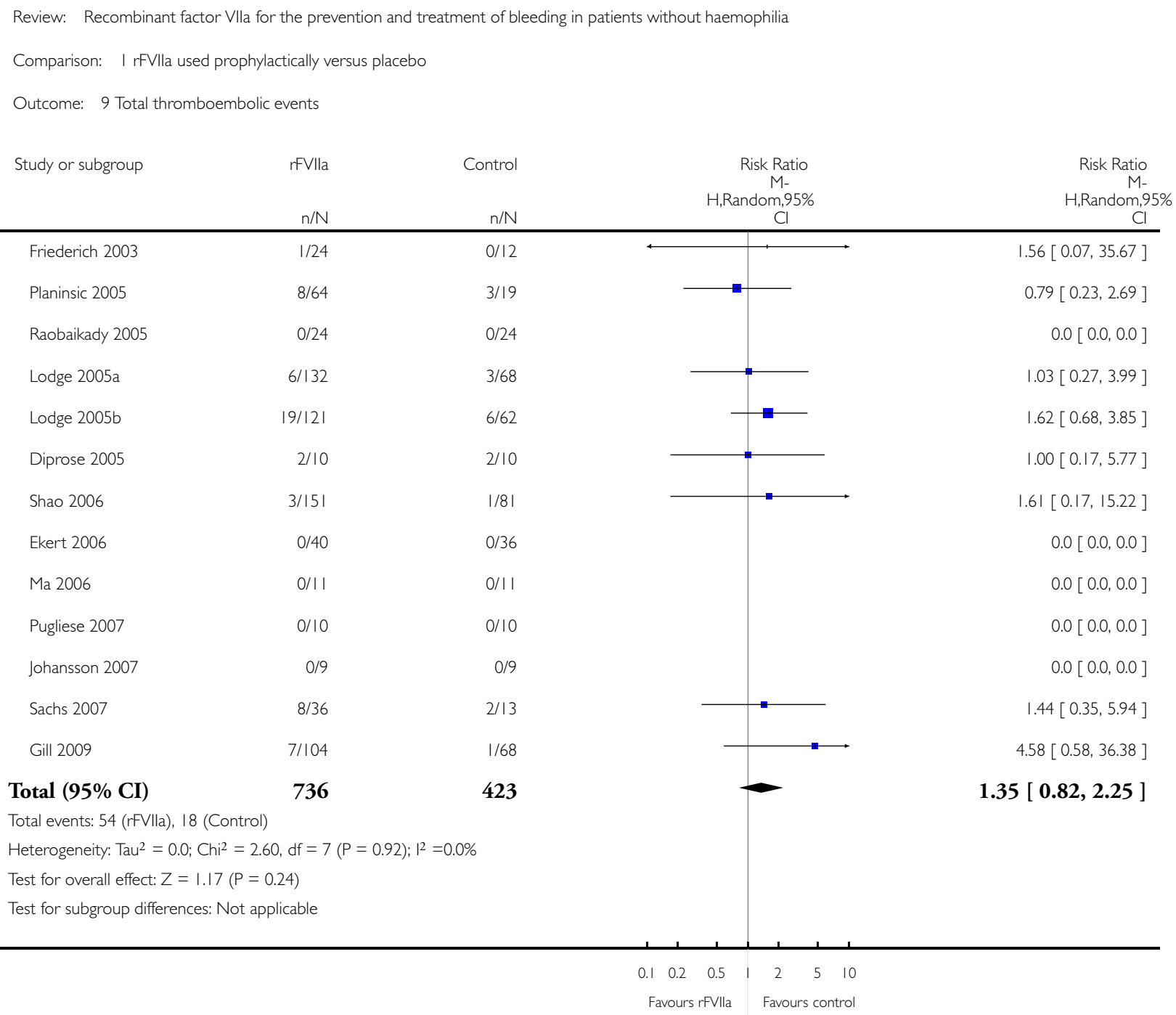




\section{Analysis I.10. Comparison I rFVIla used prophylactically versus placebo, Outcome I0 Total} thromboembolic events - exploring heterogeneity.

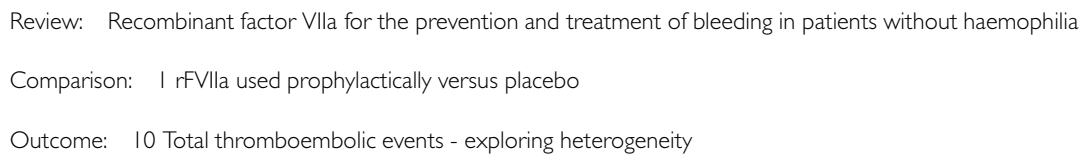

Subtotal (95\% CI)

\section{7}

8




\section{Analysis 2.I. Comparison 2 rFVIla used therapeutically versus placebo, Outcome I Death.}

Review: Recombinant factor Vlla for the prevention and treatment of bleeding in patients without haemophilia

Comparison: 2 rFVlla used therapeutically versus placebo

Outcome: I Death

Study or subgroup

Favours rFVIla

Control

Risk Ratio

M-

H,Random, $95 \%$

$\mathrm{n} / \mathrm{N} \quad \mathrm{n} / \mathrm{N}$

Bosch 2004

$16 / 116$

I |/120

Boffard 2005a

$17 / 69$

22/74

Boffard 2005b

$17 / 70$

18/64

Chuansumrit 2005

$0 / 16$

0/9

Mayer 2005a

$56 / 303$

$28 / 96$

Mayer 2005b

$3 / 36$

$2 / 11$

Pihusch 2005

$24 / 77$

$7 / 23$

Mayer 2006

$7 / 32$

1/8

Bosch 2008

$39 / 170$

25/86

Mayer 2008

| 12/557

$51 / 262$

Narayan 2008

$7 / 61$

$4 / 36$

Hauser 2010a

$26 / 224$

$28 / 250$

Hauser 2010b

$8 / 46$

$5 / 40$

Total (95\% CI)

1777

1079

Total events: 332 (Favours rFVlla), 202 (Control)

Heterogeneity: $\mathrm{Tau}^{2}=0.0 ; \mathrm{Chi}^{2}=8.62, \mathrm{df}=1 \mathrm{I}(\mathrm{P}=0.66) ; \mathrm{I}^{2}=0.0 \%$

Test for overall effect: $Z=1.18(P=0.24)$

Test for subgroup differences: Not applicable

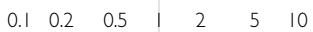

Favours rFVlla Favours control 


\section{Analysis 2.2. Comparison 2 rFVIla used therapeutically versus placebo, Outcome 2 Death - exploring heterogeneity.}

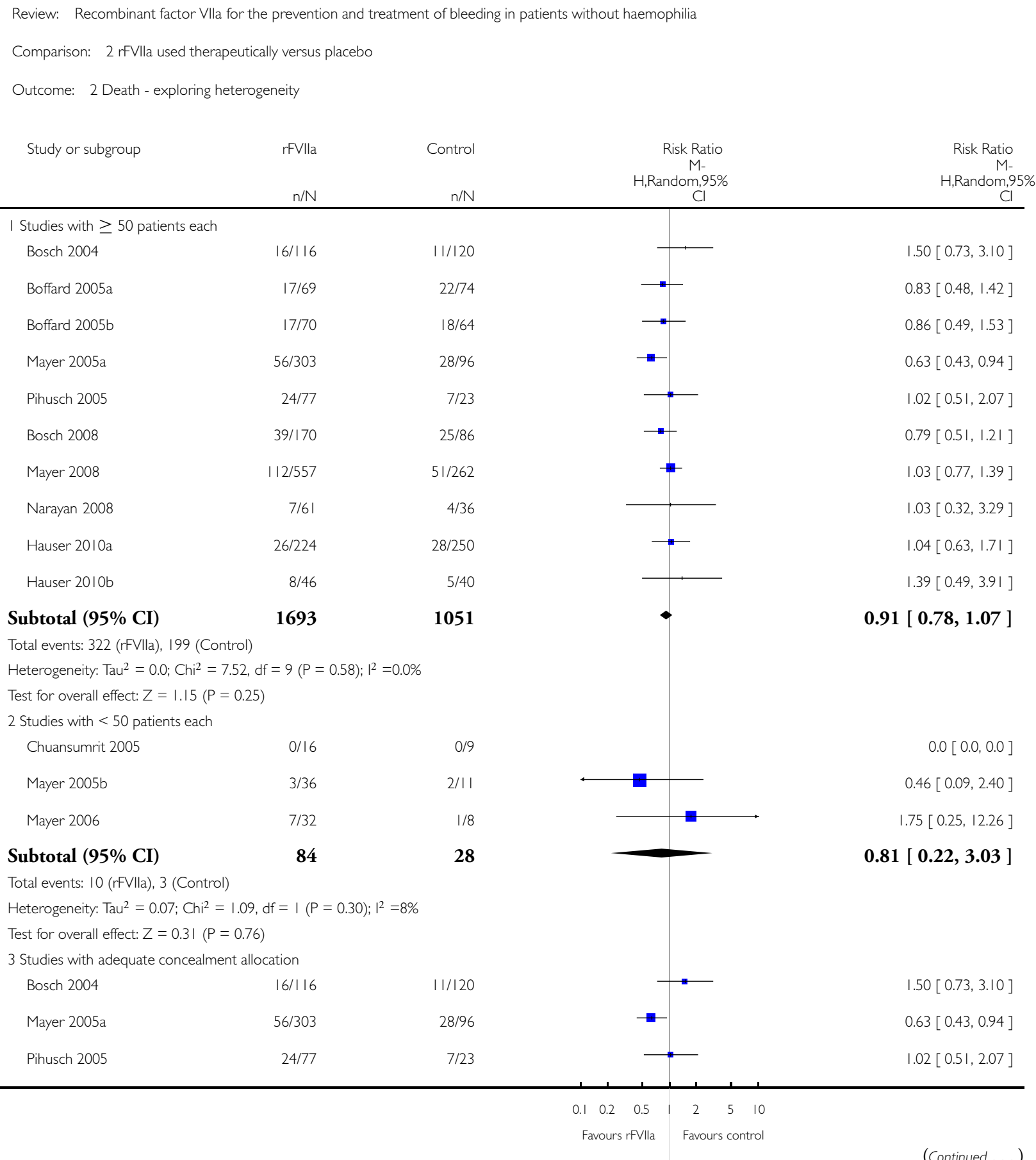




\begin{tabular}{|c|c|c|c|c|}
\hline Study or subgroup & $\begin{array}{r}\mathrm{rFVlla} \\
\mathrm{n} / \mathrm{N} \\
\end{array}$ & $\begin{array}{r}\text { Control } \\
n / N \\
\end{array}$ & $\begin{array}{r}\text { Risk Ratio } \\
\text { M- } \\
\text { H,Random,95\% } \\
\text { Cl } \\
\end{array}$ & $\begin{array}{c}\text { (... Continued) } \\
\text { Risk Ratio } \\
\text { M- } \\
\text { H,Random,95\% } \\
\text { Cl } \\
\end{array}$ \\
\hline Bosch 2008 & $39 / 170$ & $25 / 86$ & $\rightarrow$ & $0.79[0.51,1.21]$ \\
\hline Hauser 20I0a & $26 / 221$ & $28 / 247$ & & $1.04[0.63,1.71]$ \\
\hline Hauser 20I0b & $8 / 46$ & $5 / 40$ & - & $1.39[0.49,3.91]$ \\
\hline Subtotal $(95 \% \mathrm{CI})$ & 933 & 612 & $\longrightarrow$ & $0.90[0.69,1.16]$ \\
\hline \multicolumn{5}{|c|}{ Total events: 169 (rFVlla), 104 (Control) } \\
\hline \multicolumn{5}{|c|}{ Heterogeneity: $\operatorname{Tau}^{2}=0.02 ; \mathrm{Chi}^{2}=6.47, \mathrm{df}=5(P=0.26) ; \mathrm{I}^{2}=23 \%$} \\
\hline \multicolumn{5}{|c|}{ Test for overall effect: $Z=0.83(P=0.4 \mathrm{I})$} \\
\hline \multicolumn{5}{|c|}{4 Studies with transfusion protocols } \\
\hline Bosch 2004 & $16 / 116$ & $11 / 120$ & $\rightarrow$ & $1.50[0.73,3.10]$ \\
\hline Pihusch 2005 & $24 / 77$ & $7 / 23$ & - & $1.02[0.51,2.07]$ \\
\hline Bosch 2008 & $39 / 170$ & $25 / 86$ & $\rightarrow$ & $0.79[0.51,1.21]$ \\
\hline Hauser 2010a & $26 / 221$ & $28 / 247$ & & $1.04[0.63,1.71]$ \\
\hline Hauser 20I0b & $8 / 46$ & $5 / 40$ & & $1.39[0.49,3.91]$ \\
\hline Subtotal $(95 \% \mathrm{CI})$ & 630 & 516 & 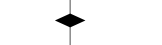 & $1.00[0.77,1.30]$ \\
\hline \multicolumn{5}{|c|}{ Total events: I I 3 (rFVlla), 76 (Control) } \\
\hline \multicolumn{5}{|c|}{ Heterogeneity: $\mathrm{Tau}^{2}=0.0 ; \mathrm{Chi}^{2}=2.83, \mathrm{df}=4(\mathrm{P}=0.59) ; \mathrm{I}^{2}=0.0 \%$} \\
\hline \multicolumn{5}{|c|}{ Test for overall effect: $Z=0.00(P=1.0)$} \\
\hline \multicolumn{5}{|c|}{5 Studies without transfusion protocols } \\
\hline Boffard 2005a & $17 / 69$ & $22 / 74$ & $\rightarrow$ & $0.83[0.48,1.42]$ \\
\hline Boffard 2005b & $17 / 70$ & $18 / 64$ & $\longrightarrow$ & $0.86[0.49,1.53]$ \\
\hline Chuansumrit 2005 & $0 / 16$ & 0/9 & & $0.0[0.0,0.0]$ \\
\hline Mayer 2005a & $56 / 303$ & $28 / 96$ & $\rightarrow$ & $0.63[0.43,0.94]$ \\
\hline Mayer 2005b & $3 / 36$ & $2 / 11$ & & $0.46[0.09,2.40]$ \\
\hline Mayer 2006 & $7 / 32$ & 1/8 & & $1.75[0.25,12.26]$ \\
\hline Mayer 2008 & | $12 / 557$ & $51 / 262$ & & $1.03[0.77,1.39]$ \\
\hline Narayan 2008 & $7 / 61$ & $4 / 36$ & & $1.03[0.32,3.29]$ \\
\hline Subtotal $(95 \% \mathrm{CI})$ & 1144 & 560 & - & $0.86[0.71,1.05]$ \\
\hline \multicolumn{5}{|c|}{ Total events: 219 (rFVlla), 126 (Control) } \\
\hline \multicolumn{5}{|c|}{ Heterogeneity: Tau $^{2}=0.0 ; \mathrm{Chi}^{2}=5.02, \mathrm{df}=6(\mathrm{P}=0.54) ; \mathrm{I}^{2}=0.0 \%$} \\
\hline Test for overall effect: $Z=$ & & & & \\
\hline
\end{tabular}


Analysis 2.3. Comparison 2 rFVIla used therapeutically versus placebo, Outcome 3 Control of bleeding (number of patients with reduced bleeding).

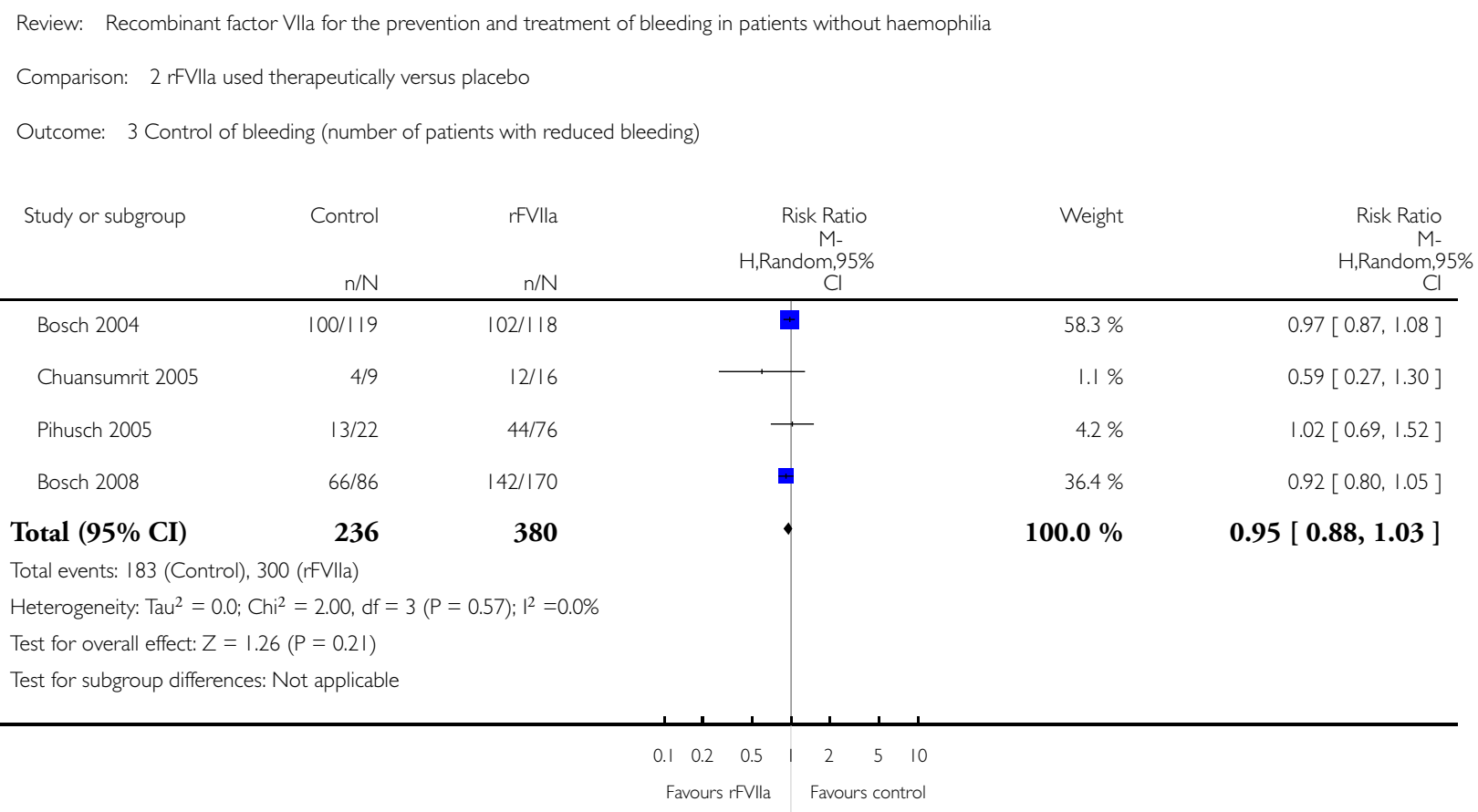


Analysis 2.4. Comparison 2 rFVIla used therapeutically versus placebo, Outcome 4 Control of bleeding exploring heterogeneity.

\begin{tabular}{|c|c|c|c|c|c|}
\hline \multicolumn{6}{|c|}{ Comparison: 2 rFVlla used therapeutically versus placebo } \\
\hline \multicolumn{6}{|c|}{ Outcome: 4 Control of bleeding - exploring heterogeneity } \\
\hline Study or subgroup & $\begin{array}{l}\text { Control } \\
n / N \\
\end{array}$ & $\begin{array}{l}\mathrm{rFVlla} \\
\mathrm{n} / \mathrm{N} \\
\end{array}$ & $\begin{array}{c}\text { Risk Ratio } \\
\text { M- } \\
\text { H,Random,95\% } \\
\text { Cl }\end{array}$ & Weight & $\begin{array}{c}\text { Risk Ratio } \\
\text { M- } \\
\text { H,Random,95\% } \\
\text { Cl }\end{array}$ \\
\hline \multicolumn{6}{|c|}{ I Studies with $\geq 50$ patients each } \\
\hline Bosch 2004 & $100 / 119$ & $102 / 118$ & $\mathbf{\theta}$ & $59.1 \%$ & $0.97[0.87,1.08]$ \\
\hline Pihusch 2005 & $13 / 22$ & $34 / 56$ & 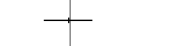 & $4.0 \%$ & $0.97[0.65,1.46]$ \\
\hline Bosch 2008 & $66 / 86$ & $142 / 170$ & E & $36.9 \%$ & $0.92[0.80,1.05]$ \\
\hline Subtotal $(95 \% \mathrm{CI})$ & 227 & 344 & $\cdot$ & $100.0 \%$ & $0.95[0.88,1.03]$ \\
\hline \multicolumn{6}{|c|}{ Total events: 179 (Control), 278 (rFVIla) } \\
\hline \multicolumn{6}{|c|}{ Heterogeneity: $\mathrm{Tau}^{2}=0.0 ; \mathrm{Chi}^{2}=0.44, \mathrm{df}=2(\mathrm{P}=0.80) ; \mathrm{I}^{2}=0.0 \%$} \\
\hline \multicolumn{6}{|c|}{ Test for overall effect: $Z=1.18(P=0.24)$} \\
\hline
\end{tabular}




\section{Analysis 2.5. Comparison 2 rFVIla used therapeutically versus placebo, Outcome 5 Red cell transfusion}

requirements $(\mathrm{mL})$.

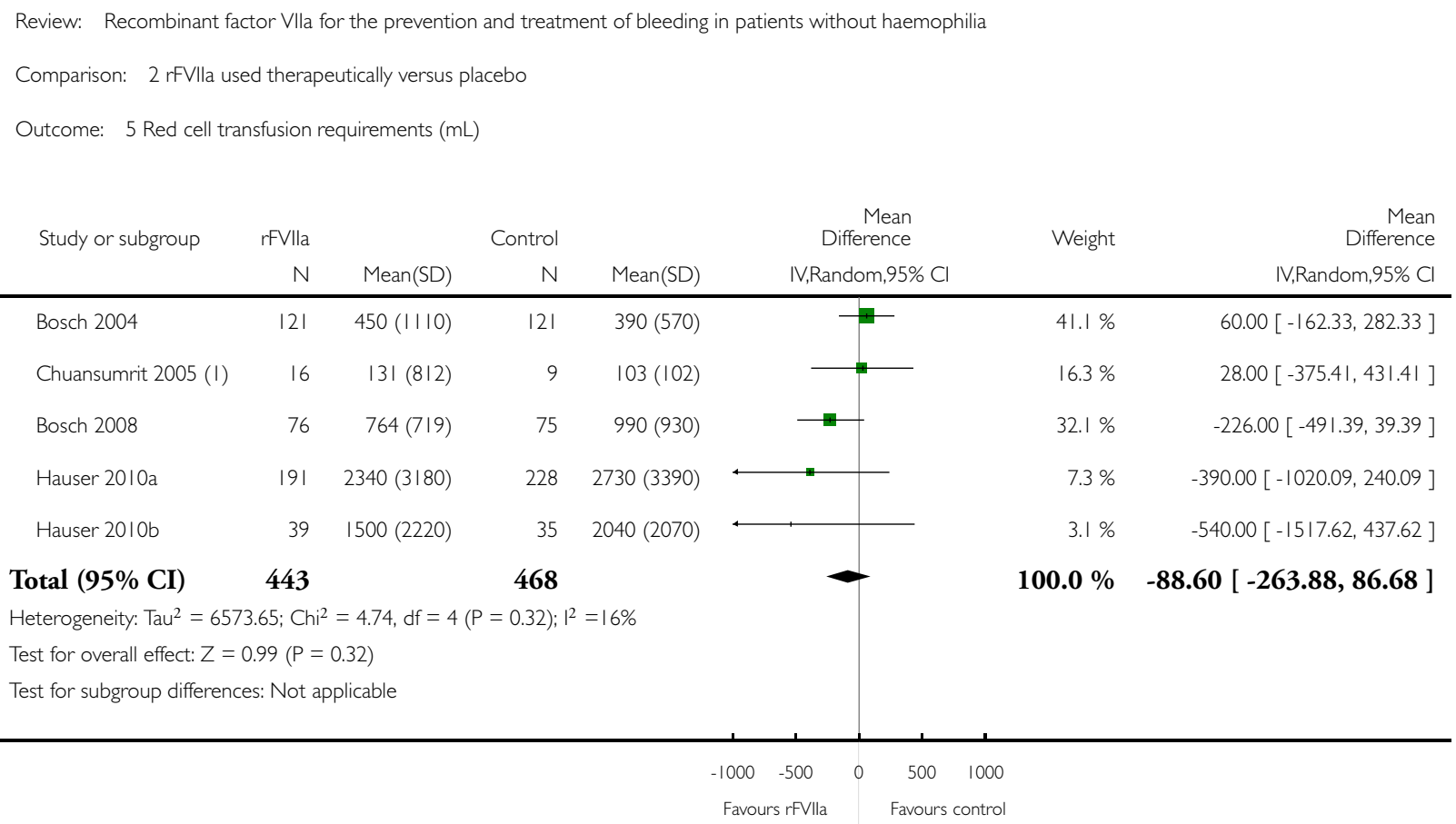

( I) Data provided per $\mathrm{kg}$ and converted to $\mathrm{mL}$ according to average weights for the mean ages indicated 


\section{Analysis 2.6. Comparison 2 rFVIla used therapeutically versus placebo, Outcome 6 Red cell transfusion} requirements $(\mathrm{mL})$ - exploring heterogeneity.

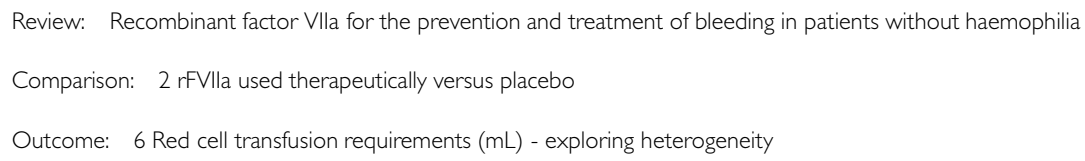




\section{Analysis 2.7. Comparison 2 rFVIla used therapeutically versus placebo, Outcome 7 Number of patients}

transfused.

Review: Recombinant factor VIla for the prevention and treatment of bleeding in patients without haemophilia

Comparison: 2 rFVlla used therapeutically versus placebo

Outcome: 7 Number of patients transfused

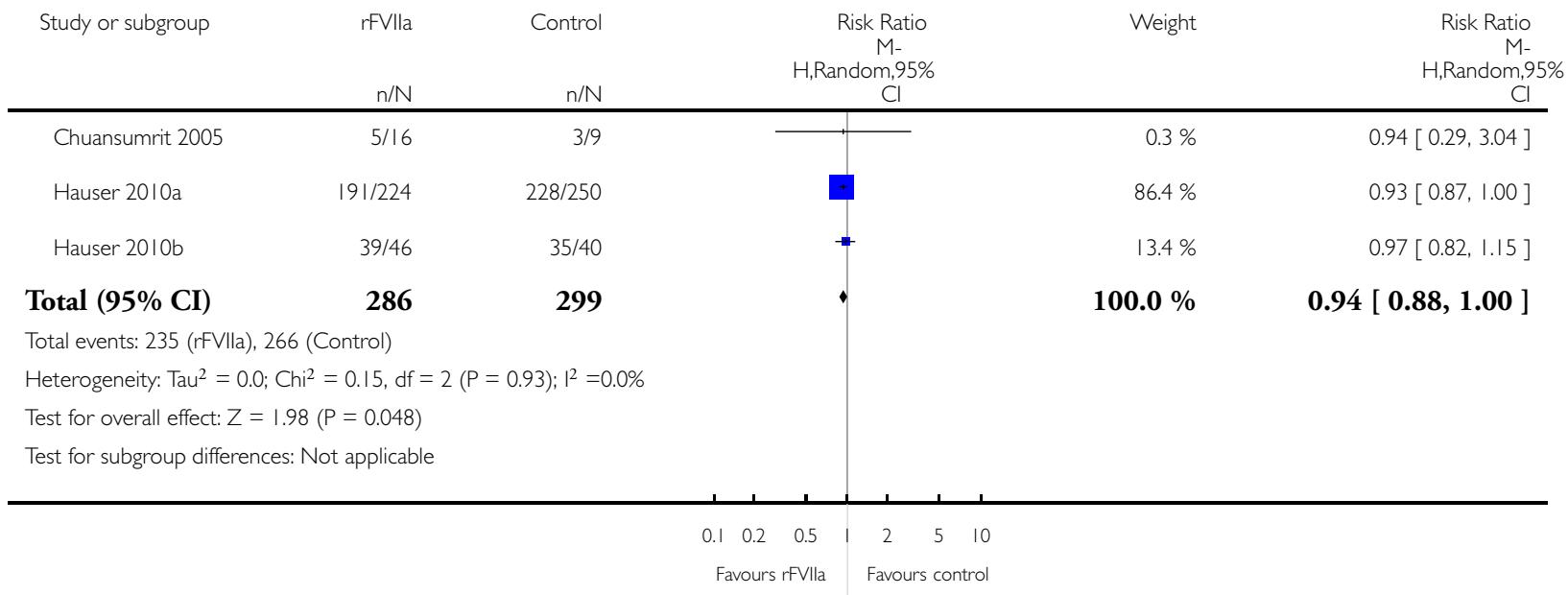


Analysis 2.8. Comparison 2 rFVIla used therapeutically versus placebo, Outcome 8 Total thromboembolic events.

Review: Recombinant factor VIla for the prevention and treatment of bleeding in patients without haemophilia

Comparison: 2 rFVlla used therapeutically versus placebo

Outcome: 8 Total thromboembolic events

Study or subgroup $\quad$ rFVlla $\quad$ Control

\begin{tabular}{lcc}
$n / N$ & $n / N$ \\
\hline Bosch 2004 & $7 / 121$ & $7 / 121$
\end{tabular}

Boffard 2005a

2/69

Boffard 2005b

4/70

$3 / 74$

Chuansumrit 2005

$0 / 16$

$3 / 64$

Mayer 2005a

$21 / 303$

Mayer 2005b

$$
5 / 36
$$

2/96

Pihusch 2005

$$
\text { 8/77 }
$$

Mayer 2006

$$
7 / 32
$$

$0 / 23$

Bosch 2008

$9 / 176$

$3 / 8$

Mayer 2008

$55 / 558$

Narayan 2008

13/61

$21 / 263$

Hauser 2010a

$36 / 224$

$5 / 36$

Hauser $2010 b$

$33 / 250$

$4 / 40$

Total (95\% CI)

1789

1084

Total events: 169 (rFVIla), 89 (Control)

Heterogeneity: $\mathrm{Tau}^{2}=0.0 ; \mathrm{Chi}^{2}=8.44, \mathrm{df}=1 \mathrm{I}(\mathrm{P}=0.67) ; \mathrm{I}^{2}=0.0 \%$

\begin{tabular}{|c|c|}
\hline $\begin{array}{r}\text { Risk Ratio } \\
\text { M- } \\
\text { H,Random,95\% } \\
\text { Cl } \\
\end{array}$ & $\begin{array}{c}\text { Risk Ratio } \\
\text { M- } \\
\text { H,Random,95\% } \\
\mathrm{Cl} \\
\end{array}$ \\
\hline$\rightarrow$ & $1.00[0.36,2.76]$ \\
\hline & $0.71[0.12,4.15]$ \\
\hline & $1.22[0.28,5.24]$ \\
\hline & $0.0[0.0,0.0]$ \\
\hline & $3.33[0.79,13.93]$ \\
\hline & $1.53[0.20,11.73]$ \\
\hline & $5.23[0.31,87.34]$ \\
\hline & $0.58[0.19,1.77]$ \\
\hline & $0.65[0.25,1.69]$ \\
\hline 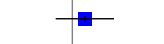 & $1.23[0.76,2.00]$ \\
\hline$\square$ & $1.53[0.60,3.95]$ \\
\hline$\rightarrow$ & $1.22[0.79,1.88]$ \\
\hline & $0.43[0.08,2.25]$ \\
\hline
\end{tabular}

Test for overall effect: $Z=1.03(P=0.30)$

Test for subgroup differences: Not applicable

$1.14[0.89,1.47]$ 


\section{Analysis 2.9. Comparison 2 rFVIla used therapeutically versus placebo, Outcome 9 Total thromboembolic events - exploring heterogeneity.}

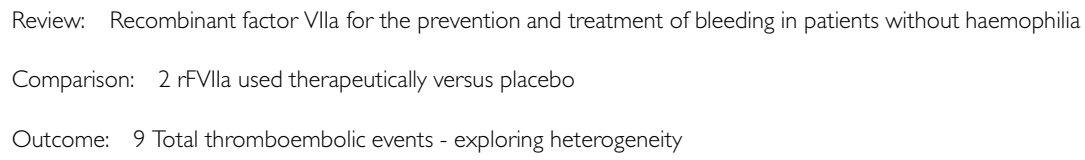

84

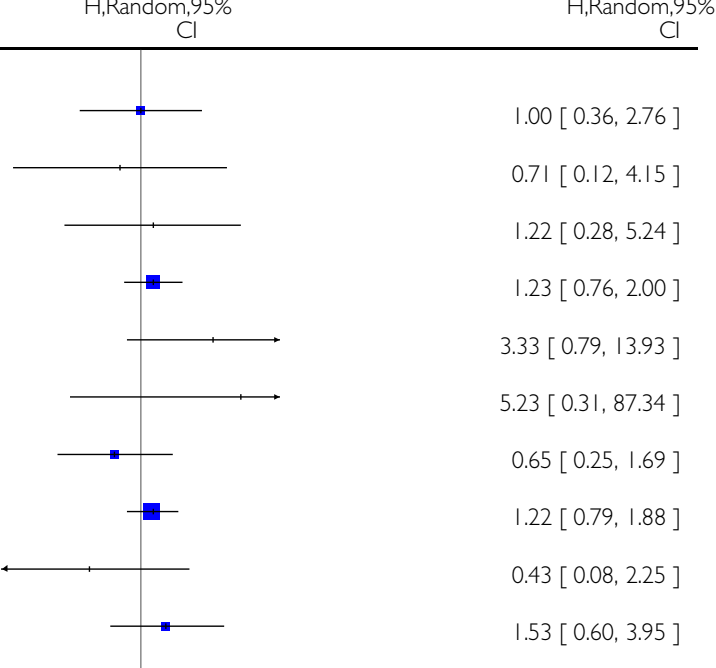

$1.18[0.91,1.54]$

$0.0[0.0,0.0]$

$1.53[0.20,11.73]$

$0.58[0.19,1.77]$

$0.73[0.27,1.92$ ]

$1.00[0.36,2.76]$

$3.33[0.79,13.93]$

$5.23[0.31,87.34]$

$\begin{array}{lllllll}0.1 & 0.2 & 0.5 & 1 & 2 & 5 & 10\end{array}$

Favours rFVIla Favours control

(Continued ... ) 


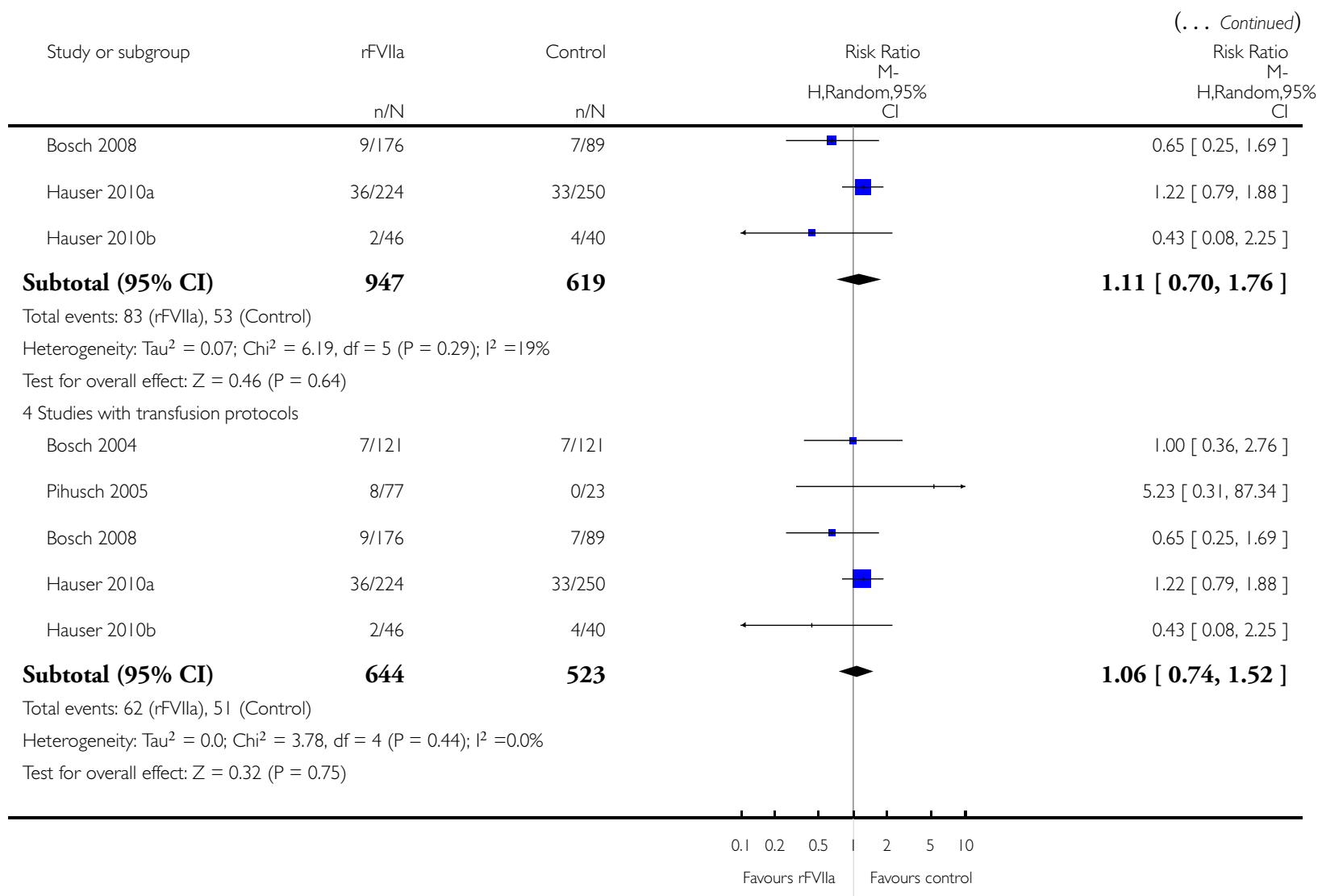


Analysis 3.I. Comparison 3 rFVIla used prophylactically or therapeutically versus placebo (adverse events), Outcome I Total thromboembolic events.

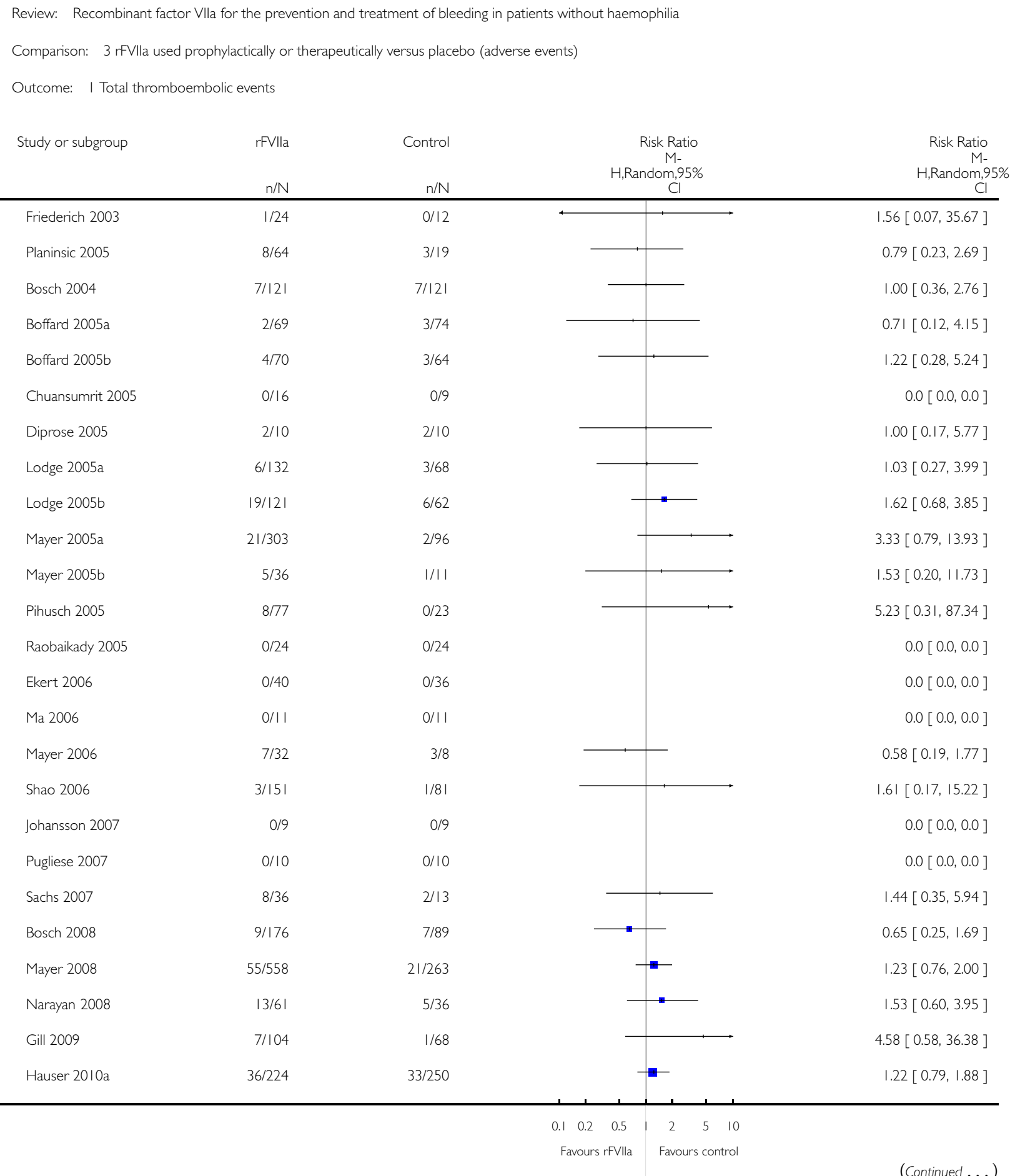

(Continued....) 


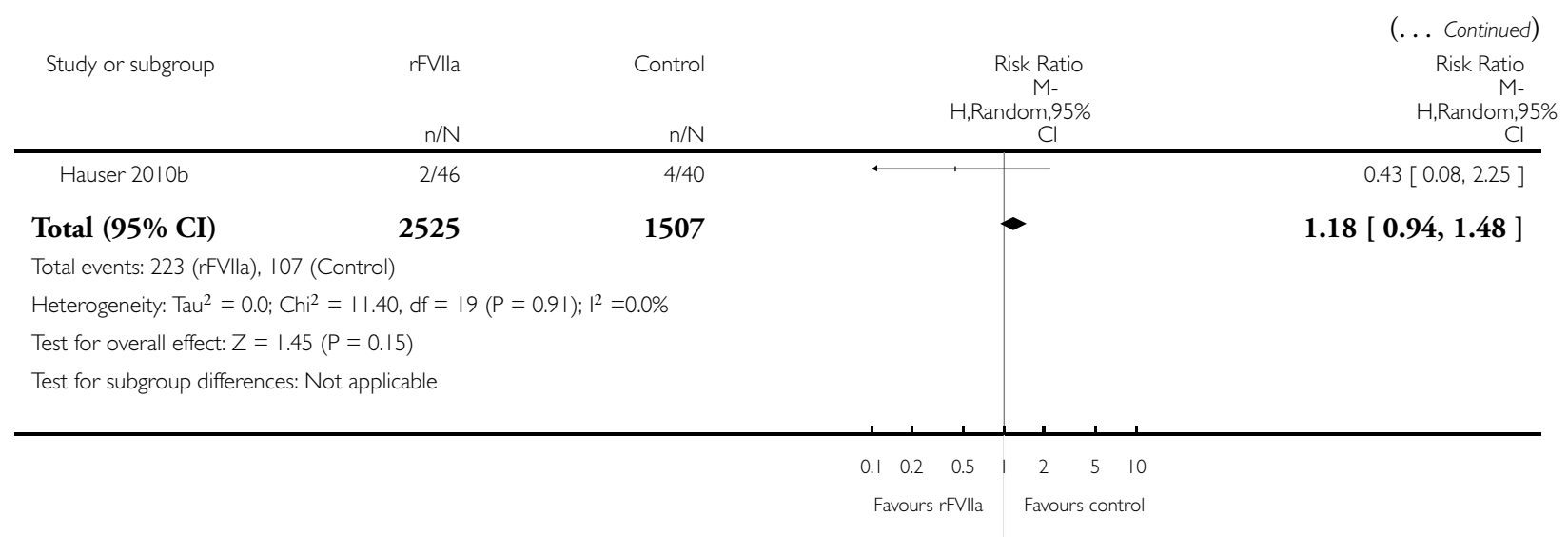

Analysis 3.2. Comparison 3 rFVIla used prophylactically or therapeutically versus placebo (adverse events), Outcome 2 Cardiovascular events, including myocardial infarction.

Review: Recombinant factor VIla for the prevention and treatment of bleeding in patients without haemophilia

Comparison: 3 rFVlla used prophylactically or therapeutically versus placebo (adverse events)

Outcome: 2 Cardiovascular events, including myocardial infarction

$\begin{array}{llcl}\text { Study or subgroup } \quad \text { rFVlla } & \text { Control Risk Ratio } & \text { M- }\end{array}$

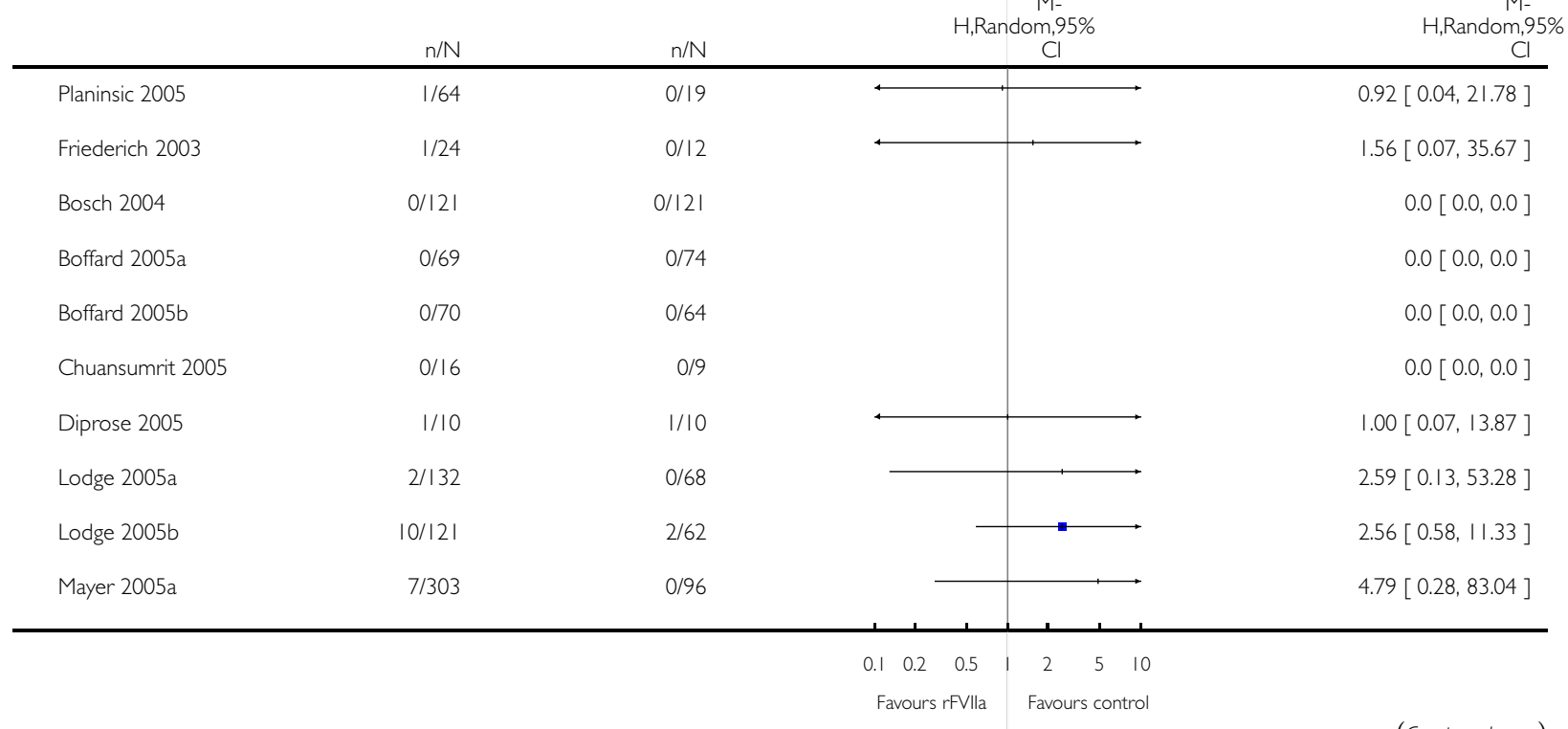

(Continued...) 


\begin{tabular}{|c|c|c|c|c|}
\hline Study or subgroup & $\begin{array}{r}\mathrm{rFVlla} \\
\mathrm{n} / \mathrm{N} \\
\end{array}$ & $\begin{array}{l}\text { Control } \\
n / N \\
\end{array}$ & $\begin{array}{c}\text { Risk Ratio } \\
\text { M- } \\
\text { H,Random,95\% } \\
\text { Cl } \\
\end{array}$ & $\begin{array}{c}\text { (.. . Continued) } \\
\text { Risk Ratio } \\
\text { M- } \\
\text { H,Random,95\% } \\
\text { Cl } \\
\end{array}$ \\
\hline Mayer 2005b & $4 / 36$ & $0 / 11$ & & $2.92[0.17,50.37]$ \\
\hline Pihusch 2005 & $2 / 77$ & $0 / 23$ & & $1.54[0.08,30.95]$ \\
\hline Raobaikady 2005 & $0 / 24$ & $0 / 24$ & & $0.0[0.0,0.0]$ \\
\hline Ekert 2006 & $0 / 40$ & $0 / 36$ & & $0.0[0.0,0.0]$ \\
\hline Ma 2006 & $0 / 11$ & $0 / 11$ & & $0.0[0.0,0.0]$ \\
\hline Mayer 2006 & $4 / 32$ & $2 / 8$ & & $0.50[0.11,2.26]$ \\
\hline Shao 2006 & $1 / 151$ & $0 / 81$ & & $1.62[0.07,39.28]$ \\
\hline Johansson 2007 & $0 / 9$ & 0/9 & & $0.0[0.0,0.0]$ \\
\hline Pugliese 2007 & $0 / 10$ & $0 / 10$ & & $0.0[0.0,0.0]$ \\
\hline Sachs 2007 & $7 / 36$ & $2 / 13$ & - & $1.26[0.30,5.32]$ \\
\hline Bosch 2008 & $3 / 176$ & $0 / 89$ & & $3.56[0.19,68.16]$ \\
\hline Mayer 2008 & $25 / 558$ & $8 / 263$ & $=$ & $1.47[0.67,3.22]$ \\
\hline Narayan 2008 & $5 / 61$ & $3 / 36$ & & $0.98[0.25,3.87]$ \\
\hline Gill 2009 & $0 / 104$ & $1 / 68$ & & $0.22[0.01,5.30]$ \\
\hline Total $(95 \% \mathrm{CI})$ & 2255 & 1217 & - & $1.35[0.85,2.15]$ \\
\hline \multicolumn{5}{|c|}{ Total events: 73 (rFVIla), 19 (Control) } \\
\hline \multicolumn{5}{|c|}{ Heterogeneity: $\operatorname{Tau}^{2}=0.0 ; \mathrm{Chi}^{2}=5.78, \mathrm{df}=14(P=0.97) ;\left.\right|^{2}=0.0 \%$} \\
\hline \multicolumn{5}{|c|}{ Test for overall effect: $Z=1.28(P=0.20)$} \\
\hline \multicolumn{5}{|c|}{ Test for subgroup differences: Not applicable } \\
\hline
\end{tabular}


Analysis 3.3. Comparison 3 rFVIIa used prophylactically or therapeutically versus placebo (adverse events), Outcome 3 Stroke.

\begin{tabular}{|c|c|c|c|c|}
\hline \multicolumn{5}{|c|}{ Comparison: $3 \mathrm{rFVlla}$ used prophylactically or therapeutically versus placebo (adverse events) } \\
\hline \multicolumn{5}{|l|}{ Outcome: 3 Stroke } \\
\hline Study or subgroup & $\begin{array}{r}\mathrm{rFVlla} \\
\mathrm{n} / \mathrm{N}\end{array}$ & $\begin{array}{l}\text { Control } \\
n / N\end{array}$ & $\begin{array}{c}\text { Risk Ratio } \\
\text { M- } \\
\text { H,Random,95\% } \\
\text { Cl }\end{array}$ & $\begin{array}{c}\text { Risk Ratio } \\
\text { M- } \\
\text { H,Random,95\% } \\
\mathrm{Cl} \\
\end{array}$ \\
\hline Planinsic 2005 & $0 / 64$ & $0 / 19$ & & $0.0[0.0,0.0]$ \\
\hline Friederich 2003 & 0/24 & $0 / 12$ & & $0.0[0.0,0.0]$ \\
\hline Bosch 2004 & $2 / 121$ & $0 / 121$ & $\longrightarrow$ & $5.00[0.24,103.07]$ \\
\hline Boffard 2005a & $0 / 69$ & $0 / 74$ & & $0.0[0.0,0.0]$ \\
\hline Boffard 2005b & $1 / 70$ & $1 / 64$ & & $0.91[0.06,14.32]$ \\
\hline Chuansumrit 2005 & $0 / 16$ & $0 / 9$ & & $0.0[0.0,0.0]$ \\
\hline Diprose 2005 & $1 / 10$ & $1 / 10$ & & $1.00[0.07,13.87]$ \\
\hline Lodge 2005a & $0 / 132$ & $0 / 68$ & & $0.0[0.0,0.0]$ \\
\hline Mayer 2005a & $9 / 303$ & $0 / 96$ & $\longrightarrow$ & $6.06[0.36,103.21]$ \\
\hline Mayer 2005b & $0 / 36$ & $0 / 11$ & & $0.0[0.0,0.0]$ \\
\hline Pihusch 2005 & $2 / 77$ & $0 / 23$ & $\longrightarrow$ & $1.54[0.08,30.95]$ \\
\hline Raobaikady 2005 & $0 / 24$ & $0 / 24$ & & $0.0[0.0,0.0]$ \\
\hline Ekert 2006 & $0 / 40$ & $0 / 36$ & & $0.0[0.0,0.0]$ \\
\hline Ma 2006 & $0 / 11$ & $0 / 11$ & & $0.0[0.0,0.0]$ \\
\hline Mayer 2006 & $0 / 32$ & $1 / 8$ & - & $0.09[0.00,2.05]$ \\
\hline Shao 2006 & $0 / 151$ & $0 / 81$ & & $0.0[0.0,0.0]$ \\
\hline Johansson 2007 & 0/9 & $0 / 9$ & & $0.0[0.0,0.0]$ \\
\hline Pugliese 2007 & $0 / 10$ & $0 / 10$ & & $0.0[0.0,0.0]$ \\
\hline Sachs 2007 & 1/36 & $0 / 13$ & & $1.14[0.05,26.25]$ \\
\hline Bosch 2008 & $0 / 176$ & $0 / 89$ & & $0.0[0.0,0.0]$ \\
\hline Mayer 2008 & $14 / 558$ & $4 / 263$ & + & $1.65[0.55,4.96]$ \\
\hline Narayan 2008 & $\mid / 61$ & 1/36 & & $0.59[0.04,9.15]$ \\
\hline Gill 2009 & $4 / 104$ & $0 / 68$ & $\longrightarrow$ & $5.91[0.32,108.12]$ \\
\hline Total $(95 \% \mathrm{CI})$ & 2134 & 1155 & - & $1.49[0.72,3.07]$ \\
\hline Total events: 35 (rFVlla & & & & \\
\hline
\end{tabular}


Heterogeneity: $\mathrm{Tau}^{2}=0.0 ; \mathrm{Chi}^{2}=6.36, \mathrm{df}=9(\mathrm{P}=0.70) ; \mathrm{I}^{2}=0.0 \%$

Test for overall effect: $Z=1.07(P=0.28)$

Test for subgroup differences: Not applicable

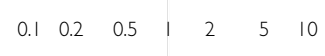

Favours rFVlla Favours control

Analysis 3.4. Comparison 3 rFVIla used prophylactically or therapeutically versus placebo (adverse events), Outcome 4 Total arterial events.

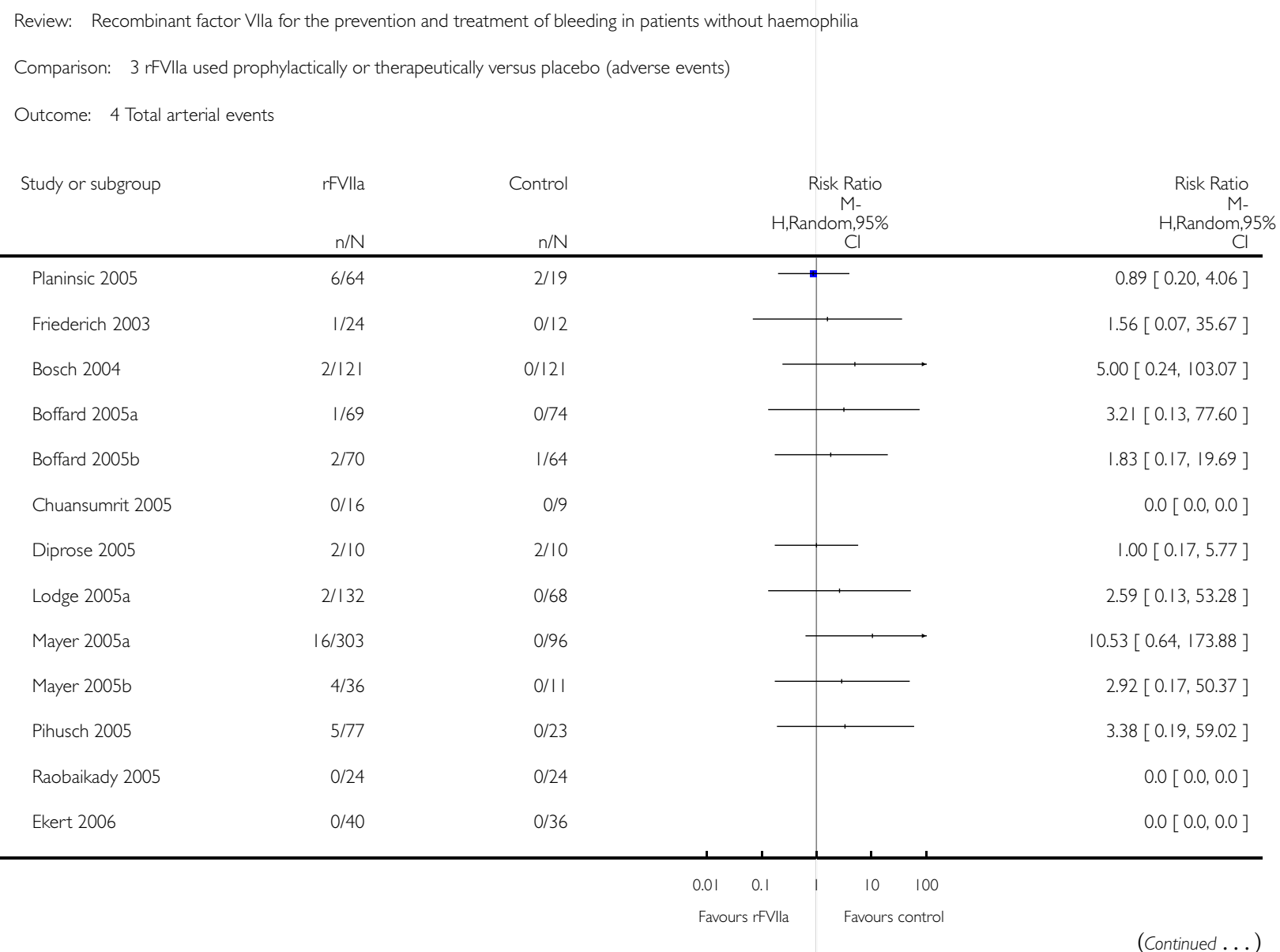




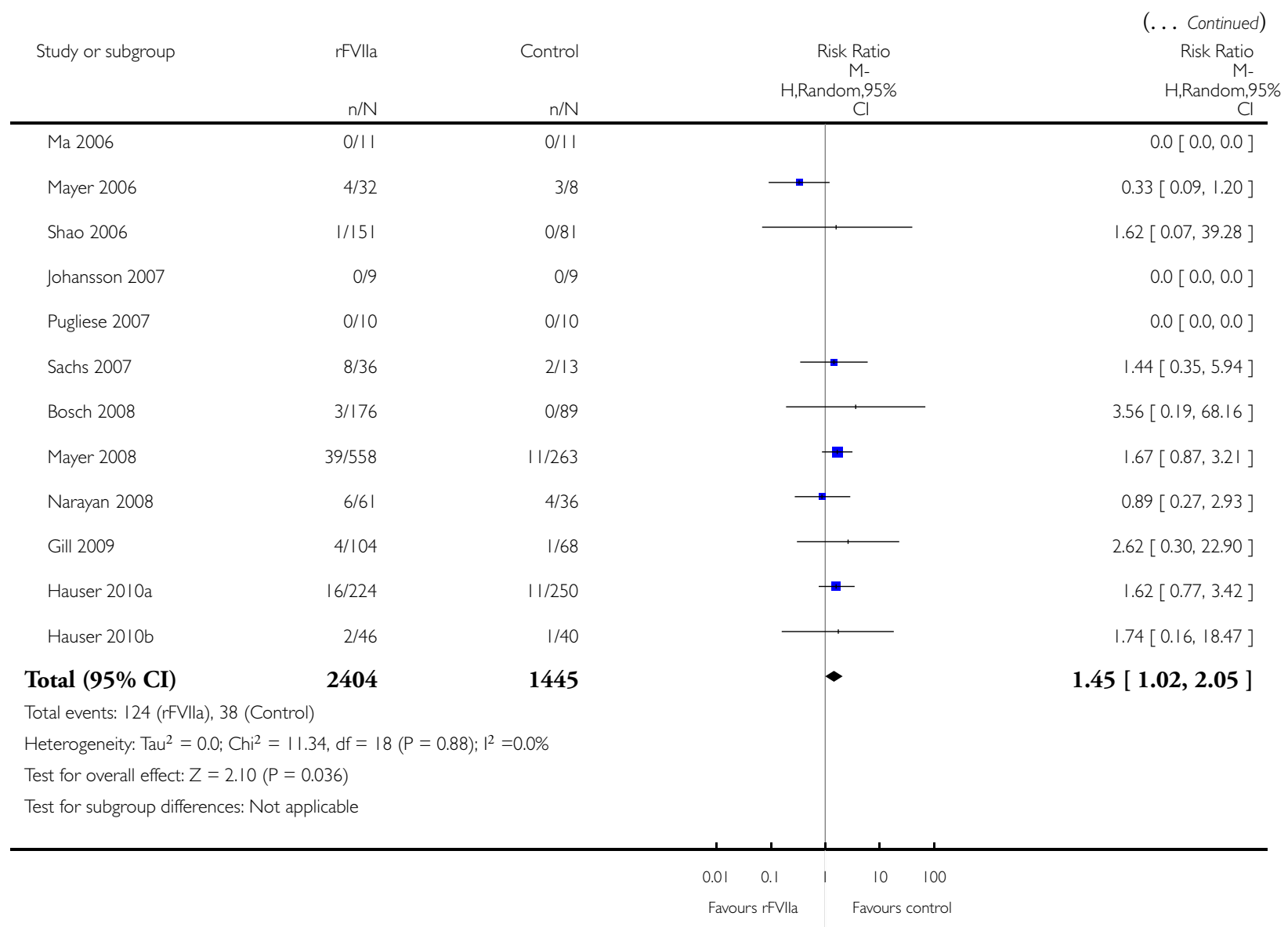


Analysis 3.5. Comparison 3 rFVIIa used prophylactically or therapeutically versus placebo (adverse events), Outcome 5 Total venous events.

Review: Recombinant factor VIla for the prevention and treatment of bleeding in patients without haemophilia

Comparison: 3 rFVlla used prophylactically or therapeutically versus placebo (adverse events)

Outcome: 5 Total venous events

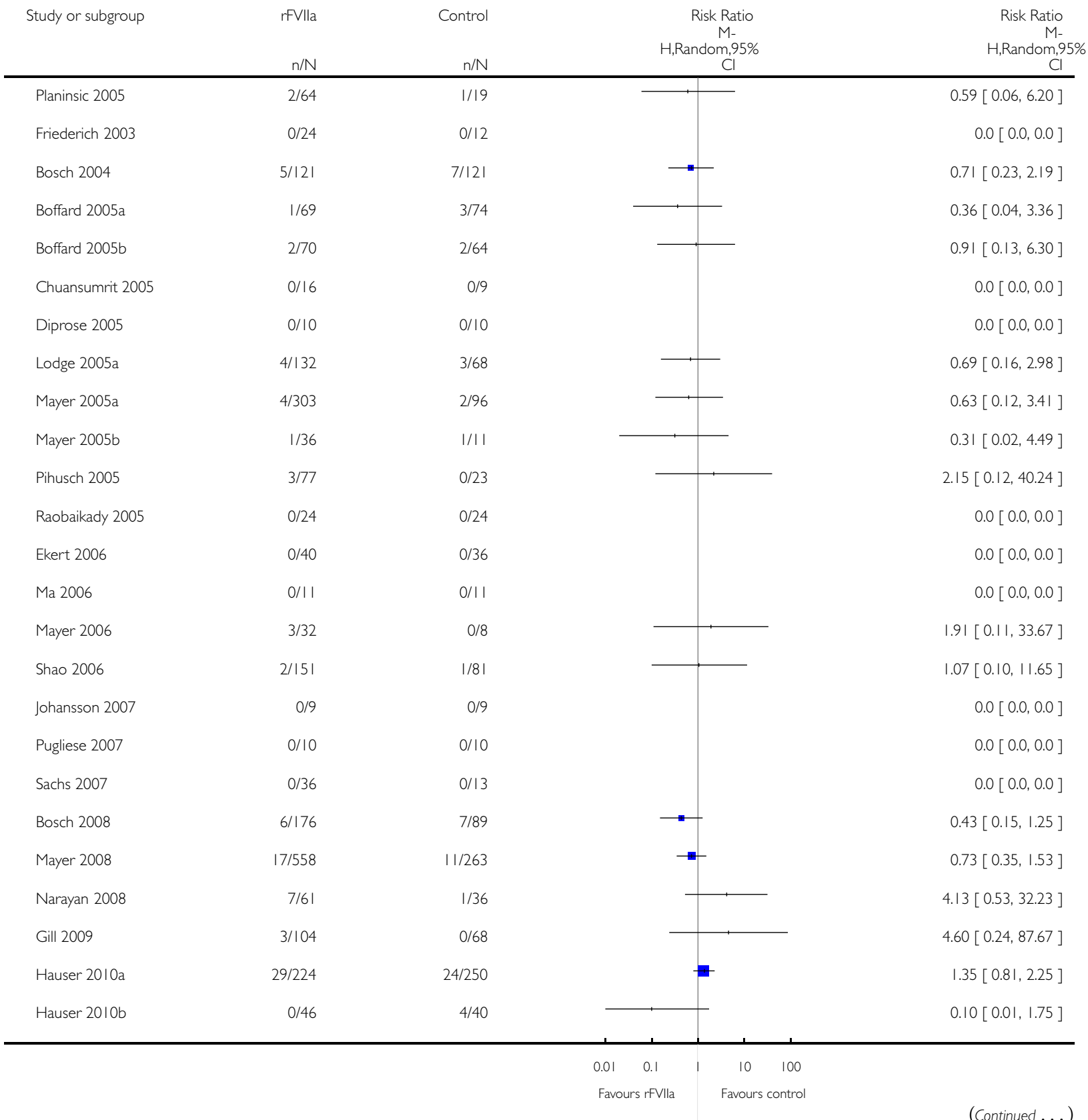

Recombinant factor VIla for the prevention and treatment of bleeding in patients without haemophilia (Review) 


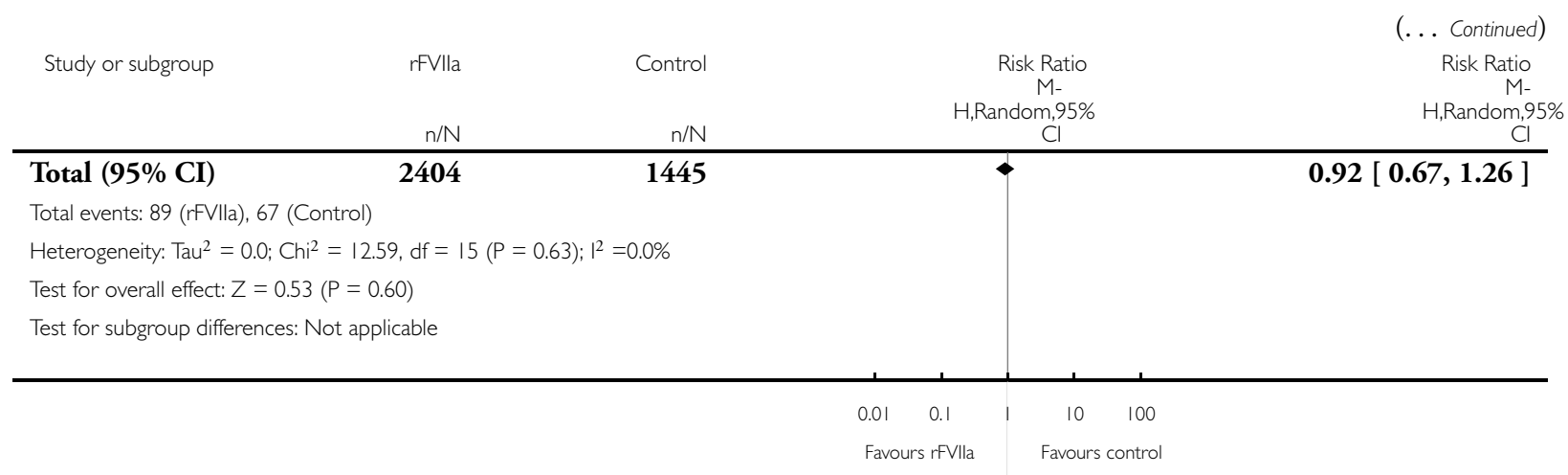

ADDITIONAL TABLES

Table 1. Status of ongoing studies from 2007 Cochrane review

\begin{tabular}{|c|c|c|c|c|c|}
\hline Author & Population & $\begin{array}{l}\text { Expected } \\
\text { enrolment }\end{array}$ & Primary outcome & Start date & $\begin{array}{l}\text { Status as of } 23 \\
\text { March } 2011\end{array}$ \\
\hline Arai 2005 & Spontaneous ICH & 90 & $\begin{array}{l}\text { TE serious adverse } \\
\text { events to } 90 \text { days }\end{array}$ & January 2006 & $\begin{array}{l}\text { Completed but not } \\
\text { yet published }\end{array}$ \\
\hline Della Corte 2006 & $\begin{array}{l}\text { Post-surgical evalua- } \\
\text { tion of intracerebral } \\
\text { haematoma }\end{array}$ & Not stated & $\begin{array}{l}\text { Postopera- } \\
\text { tive rebleeding after } \\
\text { surgery }\end{array}$ & Jan 2005 & See Imberti 2005 \\
\hline $\begin{array}{l}\text { Gaspar-Blaudschun } \\
2004\end{array}$ & Post-cardiac surgery & Not stated & $\begin{array}{l}\text { Se- } \\
\text { rious adverse events } \\
\text { within } 30 \text { days }\end{array}$ & $\begin{array}{l}\text { October } 2004 \text { to } \\
\text { November } 2007\end{array}$ & $\begin{array}{l}\text { Completed. See Gill } \\
2009 .\end{array}$ \\
\hline Gris 2006 & $\begin{array}{l}\text { Post-partum } \\
\text { haemorrhage refrac- } \\
\text { tory to other treat- } \\
\text { ment }\end{array}$ & Not stated & $\begin{array}{l}\text { Intensity of haemor- } \\
\text { rhage before and af- } \\
\text { ter VIIa; units trans- } \\
\text { fused }\end{array}$ & December 2006 & Recruiting \\
\hline Imberti 2005 & $\begin{array}{l}\text { Post-surgical evalua- } \\
\text { tion of intracerebral } \\
\text { haematoma }\end{array}$ & Not stated & $\begin{array}{l}\text { Postopera- } \\
\text { tive rebleeding after } \\
\text { surgery }\end{array}$ & $\begin{array}{l}\text { Jan } 2005 \text { to Decem- } \\
\text { ber } 2008\end{array}$ & $\begin{array}{l}\text { Completed but not } \\
\text { yet published }\end{array}$ \\
\hline Iorio 2006 & $\begin{array}{l}\text { ICH in setting of } \\
\text { oral anticoagulants } \\
\text { or antiplatelets }\end{array}$ & Not stated & $\begin{array}{l}\text { Change in ICH vol- } \\
\text { ume at } 24 \text { hours }\end{array}$ & September 2005 & Recruiting \\
\hline Kelleher 2006 & Post-cardiac surgery & Not stated & $\begin{array}{l}\text { Critical serious ad- } \\
\text { verse events }\end{array}$ & 2006 & $\begin{array}{l}\text { Completed but not } \\
\text { yet published }\end{array}$ \\
\hline
\end{tabular}

Recombinant factor VIla for the prevention and treatment of bleeding in patients without haemophilia (Review) 
Table 1. Status of ongoing studies from 2007 Cochrane review

(Continued)

\begin{tabular}{|c|c|c|c|c|c|}
\hline McCall 2005 & $\begin{array}{l}\text { Com- } \\
\text { plex cardiac surgery } \\
\text { as salvage treatment }\end{array}$ & 40 & $\begin{array}{l}\text { Adequate } \\
\text { haemostasis to en- } \\
\text { able chest closure }\end{array}$ & June 2005 & Recruiting \\
\hline Molter 2005 & $\begin{array}{l}\text { Burn excision and } \\
\text { grafting }\end{array}$ & 52 & $\begin{array}{l}\text { Perioperative blood } \\
\text { loss and transfusion }\end{array}$ & January 2006 & Recruiting \\
\hline Ng 2006 & $\begin{array}{l}\text { ECMO patients } \\
\text { post-cardiac surgery }\end{array}$ & Not stated & $\begin{array}{l}\text { Postoperative bleed- } \\
\text { ing and transfusion }\end{array}$ & April 2004 & Status unknown \\
\hline Tortella 2006 & Trauma & 1502 & $\begin{array}{l}\text { Mortality and mor- } \\
\text { bidity through day } \\
30\end{array}$ & May 2006 & $\begin{array}{l}\text { Ter- } \\
\text { minated early. See } \\
\text { Hauser 2010a and } \\
\text { Hauser 2010b }\end{array}$ \\
\hline
\end{tabular}

$\overline{\mathrm{EMCO}}$ = extracorporeal membrane oxygenation; ICH = intracranial haemorrhage; $\mathrm{TE}$ = thromboembolic

Table 2. Prophylactic RCT - overview

\begin{tabular}{|c|c|c|c|c|c|}
\hline Study & Participants & $\mathbf{N}$ & Intervention & Co-Intervention(s) & Primary outcome \\
\hline Diprose 2005 & $\begin{array}{l}\text { Complex non-coro- } \\
\text { nary cardiac surgery } \\
\text { requiring } \mathrm{CPB}\end{array}$ & 20 & $\begin{array}{l}1 \text { dose of } 90 \mu \mathrm{g} / \mathrm{kg} \text { rFVIIa } \\
\text { iv }\end{array}$ & $\begin{array}{l}\text { Transfusion for } \mathrm{Hb}<8.5 \\
\mathrm{~g} / \mathrm{dL} \\
\text { Intraoperative cell salvage } \\
\text { Aprotinin } \\
\text { Protamine for heparin re- } \\
\text { versal }\end{array}$ & $\begin{array}{l}\text { Number of patients re- } \\
\text { ceiving allogeneic transfu- } \\
\text { sion }\end{array}$ \\
\hline Ekert 2006 & $\begin{array}{l}\text { Infants }<1 \text { year with } \\
\text { congenital heart dis- } \\
\text { ease requiring } \mathrm{CPB}\end{array}$ & 82 & $\begin{array}{l}\text { First dose of } 40 \mu \mathrm{g} / \mathrm{kg} \\
\text { rFVIIa iv; repeated up to } \\
2 \text { times if ongoing bleed- } \\
\text { ing }\end{array}$ & $\begin{array}{l}\text { No transfusion protocol } \\
\text { stated } \\
\text { Protamine for heparin re- } \\
\text { versal }\end{array}$ & $\begin{array}{l}\text { Time to chest closure af- } \\
\text { ter reversal of heparin and } \\
\text { transfusion requirements }\end{array}$ \\
\hline Essam 2007 & $\begin{array}{l}\text { Elective cardiac } \\
\text { revascularisation re- } \\
\text { quiring } \mathrm{CPB}\end{array}$ & 30 & $\begin{array}{l}1 \text { dose of } 90 \mu \mathrm{g} / \mathrm{kg} \text { rFVIIa } \\
\text { iv }\end{array}$ & $\begin{array}{l}\text { Transfusion for } \mathrm{Hb}<7 \mathrm{~g} / \\
\mathrm{dL} \\
\text { Intraoperative cell salvage } \\
\text { Protamine for heparin re- } \\
\text { versal }\end{array}$ & $\begin{array}{l}\text { No stated primary out- } \\
\text { come but blood loss and } \\
\text { transfusion requirements } \\
\text { measured }\end{array}$ \\
\hline Friederich 2003 & $\begin{array}{l}\text { Retropubic prostate- } \\
\text { ctomy }\end{array}$ & 36 & $\begin{array}{l}1 \text { dose of } 20 \mu \mathrm{g} / \mathrm{kg} \text { or } 40 \\
\mu \mathrm{g} / \mathrm{kg} \text { rFVIIa iv }\end{array}$ & $\begin{array}{l}\text { Transfusion for } \mathrm{Hb}<8 \mathrm{~g} / \\
\mathrm{dL} \text { intraoperatively and }< \\
10 \mathrm{~g} / \mathrm{dL} \text { postoperatively } \\
\text { LMWH postoperatively }\end{array}$ & $\begin{array}{l}\text { Blood loss and transfusion } \\
\text { requirements }\end{array}$ \\
\hline Gill 2009 & $\begin{array}{l}\text { Adult patients un- } \\
\text { dergoing car- } \\
\text { diac surgery requir- }\end{array}$ & 179 & $\begin{array}{l}1 \text { dose of } 40 \mu \mathrm{g} / \mathrm{kg} \text { or } 80 \\
\mu \mathrm{g} / \mathrm{kg} \text { of } \mathrm{rFVIIa}\end{array}$ & $\begin{array}{l}\text { Clearly defined transfu- } \\
\text { sion protocol to maintain } \\
\mathrm{Hb}>8.0 \mathrm{~g} / \mathrm{dL}\end{array}$ & $\begin{array}{l}\text { Death, cerebral } \\
\text { infarction, myocardial in- } \\
\text { farction, pulmonary em- }\end{array}$ \\
\hline
\end{tabular}

Recombinant factor VIla for the prevention and treatment of bleeding in patients without haemophilia (Review) 
ing $\mathrm{CPB}$

bolism and other thromboembolic events

\begin{tabular}{|c|c|c|c|c|c|}
\hline Hanna 2010 & $\begin{array}{l}\text { Paediatric pa- } \\
\text { tients of ASA class I } \\
\text { and II with congen- } \\
\text { ital craniofacial mal- } \\
\text { formation under- } \\
\text { going reconstructive } \\
\text { surgery }\end{array}$ & 45 & $\begin{array}{l}\text { First dose of } 100 \mu \mathrm{g} / \mathrm{kg} \\
\text { at hour } 0 \text { over } 15 \text { minutes } \\
\text { followed by infusion of } 10 \\
\mu \mathrm{g} / \mathrm{kg} / \mathrm{h} \text { until skin closure }\end{array}$ & $\begin{array}{l}\text { Transfusion for } \mathrm{Hb}<9 \mathrm{~g} / \\
\mathrm{dL} \text {. However, blood trans- } \\
\text { fusion was instituted im- } \\
\text { mediately whenever se- } \\
\text { vere blood loss occurred } \\
\text { or was anticipated }\end{array}$ & $\begin{array}{l}\text { Primary endpoints were } \\
\text { not clearly stated, but pe- } \\
\text { rioperative blood loss and } \\
\text { transfusion requirements } \\
\text { measured }\end{array}$ \\
\hline Jeffers 2002 & $\begin{array}{l}\text { Cirrhosis and coagu- } \\
\text { lopathy undergoing } \\
\text { laparoscopic liver } \\
\text { biopsy }\end{array}$ & 66 & $\begin{array}{l}1 \text { dose of } 5 \mu \mathrm{g} / \mathrm{kg}, 20 \mu \mathrm{g} / \\
\mathrm{kg}, 80 \mu \mathrm{g} / \mathrm{kg} \text { or } 120 \mu \mathrm{g} / \\
\mathrm{kg} \text { rFVIIa iv }\end{array}$ & $\begin{array}{l}\text { No transfusion protocol } \\
\text { stated }\end{array}$ & $\begin{array}{l}\text { Time to haemostasis and } \\
\text { duration of normal PT }\end{array}$ \\
\hline Johansson 2007 & $\begin{array}{l}\text { Thermal burn un- } \\
\text { dergoing skin exci- } \\
\text { sion and grafting }\end{array}$ & 18 & $\begin{array}{l}\text { First dose of } 40 \mu \mathrm{g} / \mathrm{kg} \\
\text { rFVIIa iv; } 2 \mathrm{nd} \text { dose given } \\
\text { at } 90 \text { minutes later }\end{array}$ & $\begin{array}{l}\text { Transfusion for } \mathrm{Hb}<10 \\
\mathrm{~g} / \mathrm{dL} \text {; platelet count }<80 \mathrm{x} \\
10^{9} / \mathrm{L} \text {; and FFP in } 1: 1 \mathrm{ra}- \\
\text { tio to RBCs for microvas- } \\
\text { cular bleeding } \\
\text { LMWH postoperatively }\end{array}$ & Transfusion requirements \\
\hline Lodge $2005 a$ & Partial hepatectomy & 204 & $\begin{array}{l}\text { First dose of } 20 \mu \mathrm{g} / \mathrm{kg} \text { or } \\
80 \mu \mathrm{g} / \mathrm{kg} \mathrm{rFVIIa} \text { iv; } 2 \mathrm{nd} \\
\text { dose given at } 5 \text { hours if } \\
\text { operation longer than } 6 \\
\text { hours }\end{array}$ & $\begin{array}{l}\text { Transfusion for Hct }< \\
25 \% \text { and platelet count }< \\
30 \times 10^{9} / \mathrm{L} \\
\text { LMWH postoperatively }\end{array}$ & $\begin{array}{l}\text { Number of patients re- } \\
\text { ceiving allogeneic transfu- } \\
\text { sion }\end{array}$ \\
\hline Lodge 2005b & $\begin{array}{l}\text { Liver } \\
\text { transplantation }\end{array}$ & 209 & $\begin{array}{l}\text { First dose of } 60 \mu \mathrm{g} / \mathrm{kg} \text { or } \\
120 \mu \mathrm{g} / \mathrm{kg} \text { rFVIIa iv; re- } \\
\text { peated every } 2 \text { hours until } \\
\text { end of surgery }\end{array}$ & $\begin{array}{l}\text { Transfusion for Hct }< \\
25 \% \text {, platelet count }<30 \\
\text { x } 10^{9} / \mathrm{L} \text {; and coagulation } \\
\text { ratios }>1.5 \text { times normal }\end{array}$ & Transfusion requirements \\
\hline Ma 2006 & $\begin{array}{l}\text { Cardiac valve re- } \\
\text { placement requiring } \\
\mathrm{CPB}\end{array}$ & 22 & $\begin{array}{l}1 \text { dose of } 40 \mu \mathrm{g} / \mathrm{kg} \text { rFVIIa } \\
\text { iv }\end{array}$ & $\begin{array}{l}\text { No transfusion protocol } \\
\text { stated } \\
\text { Protamine for heparin re- } \\
\text { versal }\end{array}$ & $\begin{array}{l}\text { No stated primary out- } \\
\text { come but blood loss and } \\
\text { transfusion requirements } \\
\text { measured }\end{array}$ \\
\hline Planinsic 2005 & $\begin{array}{l}\text { Liver } \\
\text { transplantation }\end{array}$ & 87 & $\begin{array}{l}1 \text { dose of } 20 \mu \mathrm{g} / \mathrm{kg}, 40 \mu \mathrm{g} / \\
\mathrm{kg} \text { or } 80 \mu \mathrm{g} / \mathrm{kg} \text { rFVIIa iv }\end{array}$ & $\begin{array}{l}\text { Transfusion for Hct }< \\
25 \% \text {, platelet count }<30 \\
\text { x } 10^{9} / \mathrm{L} \text {; and coagulation } \\
\text { ratios }>1.5 \text { times normal }\end{array}$ & Transfusion requirements \\
\hline Pugliese 2007 & $\begin{array}{l}\text { Liver } \\
\text { transplantation }\end{array}$ & 20 & $\begin{array}{l}1 \text { dose of } 40 \mu \mathrm{g} / \mathrm{kg} \text { rFVIIa } \\
\text { iv }\end{array}$ & $\begin{array}{l}\text { Transfusion for } \mathrm{Hb}<10 \mathrm{~g} / \\
\mathrm{dL} \text { and } \mathrm{INR}>1.5\end{array}$ & $\begin{array}{l}\text { No stated primary out- } \\
\text { come but blood loss and } \\
\text { transfusion requirements } \\
\text { measured }\end{array}$ \\
\hline
\end{tabular}


Table 2. Prophylactic RCT - overview (Continued)

\begin{tabular}{|c|c|c|c|c|c|}
\hline Raobaikady 2005 & $\begin{array}{l}\text { Re- } \\
\text { constructive surgery } \\
\text { for traumatic pelvic } \\
\text { fractures }\end{array}$ & 48 & $\begin{array}{l}\text { First dose of } 90 \mu \mathrm{g} / \mathrm{kg} \\
\text { rFVIIa iv; } 2 \text { nd dose given } \\
\text { at } 2 \text { hours if ongoing } \\
\text { bleeding }\end{array}$ & $\begin{array}{l}\text { Transfusion for } \mathrm{Hb}<8 \mathrm{~g} / \\
\mathrm{dL} \text {; platelet count }<100 \\
\mathrm{x} 10^{9} / \mathrm{L} \text {; and coagulation } \\
\text { ratios }>1.5 \text { times normal } \\
\text { Intraoperative cell salvage } \\
\text { LMWH perioperatively }\end{array}$ & Blood loss \\
\hline Sachs 2007 & $\begin{array}{l}\text { Spinal fusion } \\
\text { surgery }\end{array}$ & 60 & $\begin{array}{l}\text { First dose of } 30 \mu \mathrm{g} / \mathrm{kg} \text {, } \\
60 \mu \mathrm{g} / \mathrm{kg} \text { or } 120 \mu \mathrm{g} / \mathrm{kg} \\
\text { rFVIIa iv at dosing trig- } \\
\text { ger; repeated in } 2 \text { and } 4 \\
\text { hours after initial dose }\end{array}$ & $\begin{array}{l}\text { Transfusion for } \mathrm{Hb}<9 \\
\mathrm{~g} / \mathrm{dL} \text {; platelet count }<75 \\
\text { x } 109 / \mathrm{L} \text {; and coagulation } \\
\text { ratios }>1.5 \text { times normal } \\
\text { Topical haemostatic } \\
\text { agents }\end{array}$ & $\begin{array}{l}\text { Adverse events and blood } \\
\text { loss }\end{array}$ \\
\hline Shao 2006 & Partial hepatectomy & 235 & $\begin{array}{l}\text { First dose of } 50 \mu \mathrm{g} / \mathrm{kg} \text { or } \\
100 \mu \mathrm{g} / \mathrm{kg} \text { rFVIIa iv; re- } \\
\text { peated every } 2 \text { hours un- } \\
\text { til end of surgery to max- } \\
\text { imum of } 4 \text { doses }\end{array}$ & $\begin{array}{l}\text { Transfusion if RBC loss > } \\
500 \mathrm{~mL} \\
\text { Aprotinin if critical bleed- } \\
\text { ing }\end{array}$ & $\begin{array}{l}\text { Number of patients re- } \\
\text { ceiving allogeneic transfu- } \\
\text { sion and transfusion re- } \\
\text { quirements }\end{array}$ \\
\hline
\end{tabular}

Table 3. Therapeutic RCT - overview

\begin{tabular}{|c|c|c|c|c|c|}
\hline Study & Participants & $\mathbf{N}$ & Intervention & Co-intervention(s) & Primary outcome \\
\hline Boffard 2005a & Blunt trauma & 158 & $\begin{array}{l}\text { First dose of } 200 \mu \mathrm{g} / \mathrm{kg} \\
\text { rFVIIa iv; repeated doses } \\
\text { of } 100 \mu \mathrm{g} / \mathrm{kg} \text { at } 1 \text { and } 3 \\
\text { hours after initial dose }\end{array}$ & $\begin{array}{l}\text { No transfusion protocol } \\
\text { stated }\end{array}$ & Transfusion requirements \\
\hline Boffard 2005b & Penetrating trauma & 143 & $\begin{array}{l}\text { First dose of } 200 \mu \mathrm{g} / \mathrm{kg} \\
\text { rFVIIa iv; repeated doses } \\
\text { of } 100 \mu \mathrm{g} / \mathrm{kg} \text { at } 1 \text { and } 3 \\
\text { hours after initial dose }\end{array}$ & $\begin{array}{l}\text { No transfusion protocol } \\
\text { stated }\end{array}$ & Transfusion requirements \\
\hline Bosch 2004 & $\begin{array}{l}\text { Upper gastrointesti- } \\
\text { nal haemorrhage in } \\
\text { patients with cirrho- } \\
\text { sis }\end{array}$ & 245 & $\begin{array}{l}\text { First dose of } 100 \mu \mathrm{g} / \mathrm{kg} \\
\text { rFVIIa iv; repeated doses } \\
\text { at } 2,4,6,12,18,24 \text { and } \\
30 \text { hours after initial dose }\end{array}$ & $\begin{array}{l}\text { Transfusion to maintain } \\
\text { Hct } 25 \% \text { to } 30 \% \\
\text { Vasoactive therapy } \\
\text { Endoscopic therapy }\end{array}$ & $\begin{array}{l}\text { Combined endpoint of } \\
\text { control of bleeding or re- } \\
\text { bleeding or death }\end{array}$ \\
\hline Bosch 2008 & $\begin{array}{l}\text { Upper gastrointesti- } \\
\text { nal haemorrhage in } \\
\text { patients with cirrho- } \\
\text { sis }\end{array}$ & 265 & $\begin{array}{l}\text { First dose } 200 \mu \mathrm{g} / \mathrm{kg} \\
\text { rFVIIa iv; repeated doses } \\
\text { at } 2,8,14 \text { and } 20 \text { hours } \\
\text { after initial dose; or repeat }\end{array}$ & $\begin{array}{l}\text { Transfusion to maintain } \\
\text { Hct } 25 \% \text { to } 30 \% \text { and for } \\
\text { platelet count }<30 \times 10^{9} \text { / } \\
\text { L }\end{array}$ & $\begin{array}{l}\text { Combined endpoint of } \\
\text { control of bleeding or re- } \\
\text { bleeding or death }\end{array}$ \\
\hline
\end{tabular}

Recombinant factor VIla for the prevention and treatment of bleeding in patients without haemophilia (Review) 


\begin{tabular}{|c|c|c|c|c|c|}
\hline & & & $\begin{array}{l}\text { dose } 2 \text { hours after initial } \\
\text { dose }\end{array}$ & $\begin{array}{l}\text { Vasoactive therapy } \\
\text { Endoscopic therapy } \\
\text { Prophylactic antibiotic } \\
\text { therapy }\end{array}$ & \\
\hline Chuansumrit 2005 & $\begin{array}{l}\text { Children } \\
\text { with dengue haem- } \\
\text { orrhagic fever }\end{array}$ & 28 & $\begin{array}{l}\text { First dose of } 100 \mu \mathrm{g} / \mathrm{kg} \\
\mathrm{rFVIIa} \text { iv; repeated dose } \\
\text { at } 30 \text { minutes if ongoing } \\
\text { bleeding }\end{array}$ & $\begin{array}{l}\text { No transfusion protocol } \\
\text { stated } \\
\text { Nasal packing for epis- } \\
\text { taxis } \\
\text { Ranitidine or omeprazole }\end{array}$ & Change in bleeding \\
\hline Hauser 2010a & $\begin{array}{l}\text { Adult patients who } \\
\text { had sustained blunt } \\
\text { trauma }\end{array}$ & 481 & $\begin{array}{l}\text { First dose of } 200 \mu \mathrm{g} / \mathrm{kg} \\
\text { of rFVIIa at } 0 \text { hour; re- } \\
\text { peated doses of } 100 \mu \mathrm{g} / \\
\mathrm{kg} \text { at } 1 \text { hour and } 3 \text { hours }\end{array}$ & $\begin{array}{l}\text { Evidence- } \\
\text { based guidelines and pro- } \\
\text { tocols to maintain } \mathrm{Hb} 8 \\
\text { to } 10 \mathrm{~g} / \mathrm{dL} \text { for first } 24 \\
\text { hours and } \mathrm{Hb}>7 \mathrm{~g} / \mathrm{dL} \\
\text { thereafter (unless haemo- } \\
\text { dynamically unsta- } \\
\text { ble) Platelets to maintain } \\
>50 \times 10^{9} / \mathrm{L} \text { and FFP/ } \\
\text { cryoprecipitate to main- } \\
\text { tain INR }<1.5 \text { or if bleed- } \\
\text { ing }\end{array}$ & $\begin{array}{l}1^{\text {st }} \text { tier endpoint was su- } \\
\text { periority in all-cause } 30- \\
\text { day mortality in blunt } \\
\text { trauma. If not met, the } 2 \\
\text { nd } \\
\text { tier primary conditional } \\
\text { endpoint of non-inferior- } \\
\text { ity of mortality and su- } \\
\text { periority on durable mor- } \\
\text { bidity was applied }\end{array}$ \\
\hline Hauser $2010 \mathrm{~b}$ & $\begin{array}{l}\text { Adult patients who } \\
\text { had sustained pene- } \\
\text { trating trauma }\end{array}$ & 92 & $\begin{array}{l}\text { First dose of } 200 \mu \mathrm{g} / \mathrm{kg} \\
\text { of rFVIIa at } 0 \text { hour; re- } \\
\text { peated doses of } 100 \mu \mathrm{g} / \\
\mathrm{kg} \text { at } 1 \text { hour and } 3 \text { hours }\end{array}$ & $\begin{array}{l}\text { Evidence- } \\
\text { based guidelines and pro- } \\
\text { tocols to maintain } \mathrm{Hb} 8 \\
\text { to } 10 \mathrm{~g} / \mathrm{dL} \text { for first } 24 \\
\text { hours and } \mathrm{Hb}>7 \mathrm{~g} / \mathrm{dL} \\
\text { thereafter (unless haemo- } \\
\text { dynamically unsta- } \\
\text { ble) Platelets to maintain } \\
>50 \times 10^{9} / \mathrm{L} \text { and FFP/ } \\
\text { cryoprecipitate to main- } \\
\text { tain INR }<1.5 \text { or if bleed- } \\
\text { ing }\end{array}$ & $\begin{array}{l}1^{\text {st }} \text { tier endpoint was su- } \\
\text { periority in all-cause } 30- \\
\text { day mortality in blunt } \\
\text { trauma. If not met, the } 2 \\
n d \\
\text { tier primary conditional } \\
\text { endpoint of non-inferior- } \\
\text { ity of mortality and su- } \\
\text { periority on durable mor- } \\
\text { bidity was applied }\end{array}$ \\
\hline Mayer 2005a & Spontaneous ICH & 400 & $\begin{array}{l}1 \text { dose of } 40 \mu \mathrm{g} / \mathrm{kg}, 80 \\
\mu \mathrm{g} / \mathrm{kg} \text { or } 160 \mu \mathrm{g} / \mathrm{kg} \text { of } \\
\text { rFVIIa iv }\end{array}$ & $\begin{array}{l}\text { No transfusion protocol } \\
\text { stated } \\
\text { Medical management fol- } \\
\text { lowing AHA guidelines }\end{array}$ & $\begin{array}{l}\text { Change in volume of } \\
\mathrm{ICH}\end{array}$ \\
\hline Mayer 2005b & Spontaneous ICH & 48 & $\begin{array}{l}1 \text { dose of } 10 \mu \mathrm{g} / \mathrm{kg}, 20 \\
\mu \mathrm{g} / \mathrm{kg}, 40 \mu \mathrm{g} / \mathrm{kg}, 80 \mu \mathrm{g} / \\
\mathrm{kg}, 120 \mu \mathrm{g} / \mathrm{kg} \text { or } 160 \mu \mathrm{g} / \\
\mathrm{kg} \text { of rFVIIa iv }\end{array}$ & $\begin{array}{l}\text { No transfusion protocol } \\
\text { stated } \\
\text { Medical management fol- } \\
\text { lowing AHA guidelines }\end{array}$ & Adverse events \\
\hline
\end{tabular}


Table 3. Therapeutic RCT - overview (Continued)

\begin{tabular}{|c|c|c|c|c|c|}
\hline Mayer 2006 & Spontaneous ICH & 41 & $\begin{array}{l}1 \text { dose of } 5 \mu \mathrm{g} / \mathrm{kg}, 20 \mu \mathrm{g} / \\
\mathrm{kg}, 40 \mu \mathrm{g} / \mathrm{kg} \text { or } 80 \mu \mathrm{g} / \mathrm{kg} \\
\text { of rFVIIa iv }\end{array}$ & $\begin{array}{l}\text { No transfusion protocol } \\
\text { stated } \\
\text { Medical management fol- } \\
\text { lowing AHA guidelines }\end{array}$ & Adverse events \\
\hline Mayer 2008 & Spontaneous ICH & 841 & $\begin{array}{l}1 \mathrm{dose} \text { of } 20 \mu \mathrm{g} / \mathrm{kg} \text { or } 80 \\
\mu \mathrm{g} / \mathrm{kg} \text { of rFVIIa iv }\end{array}$ & $\begin{array}{l}\text { No transfusion protocol } \\
\text { stated } \\
\text { Medical management fol- } \\
\text { lowing AHA guidelines }\end{array}$ & Severe disability or death \\
\hline Narayan 2008 & Traumatic ICH & 97 & $\begin{array}{l}1 \text { dose of } 40 \mu \mathrm{g} / \mathrm{kg}, 80 \\
\mu \mathrm{g} / \mathrm{kg}, 120 \mu \mathrm{g} / \mathrm{kg}, 160 \\
\mu \mathrm{g} / \mathrm{kg} \text { or } 200 \mu \mathrm{g} / \mathrm{kg} \text { of } \\
\text { rFVIIa iv }\end{array}$ & $\begin{array}{l}\text { No transfusion protocol } \\
\text { stated }\end{array}$ & Adverse events \\
\hline Pihusch 2005 & $\begin{array}{l}\text { Post-haematopoi- } \\
\text { etic stem cell trans- } \\
\text { plantation }\end{array}$ & 100 & $\begin{array}{l}\text { First dose of } 40 \mu \mathrm{g} / \mathrm{kg}, 80 \\
\mu \mathrm{g} / \mathrm{kg} \text { or } 160 \mu \mathrm{g} / \mathrm{kg} \text {; re- } \\
\text { peated every } 6 \text { hours x } 6 \\
\text { doses }\end{array}$ & $\begin{array}{l}\text { Transfusion for } \mathrm{Hb}<8 \mathrm{~g} / \\
\mathrm{dL} \text { and platelet count }< \\
20 \times 10^{9} / \mathrm{L}\left(<75 \times 10^{9} /\right. \\
\mathrm{L} \text { in haemorrhagic cystitis } \\
\text { or diffuse alveolar haem- } \\
\text { orrhage }) \\
\text { Heparin, defibrotide, } \\
\text { NSAIDs }\end{array}$ & Change in bleeding \\
\hline
\end{tabular}

\section{A P P E N D I C ES}

\section{Appendix I. CENTRAL search strategy (The Cochrane Library)}

\#1 FACTOR VIIA single term $(\mathrm{MeSH})$

\#2 factor viia OR factor 7a OR rfviia OR fviia

\#3 (activated NEAR/2 factor seven) OR (activated NEAR/2 factor vii) OR (activated NEAR/2 rfvii) OR (activated NEAR/2 fvii)

\#4 novoseven* OR novo seven* OR eptacog* OR proconvertin* or novo7

\#5 (factor seven OR factor vii OR factor 7):ti

\#6 \#1 OR \#2 OR \#3 OR \#4 OR \#5

\#7 HEMORRHAGE explode all trees $(\mathrm{MeSH})$

\#8 hemorrhag* or haemorrhag* OR bleed* OR bloodloss* OR blood NEAR/3 los* OR ICH

\#9 HEMOSTASIS explode all trees $(\mathrm{MeSH})$

\#10 hemosta* OR haemosta* OR surg* or operat* OR perioperat* OR resect* OR transplant* OR * tomy OR trauma* or transfus* or emergenc* or polytrauma* $^{*}$ or injur* or accident* $^{*}$

\#11 \#7 OR \#8 OR \#9 OR \#10

Recombinant factor VIla for the prevention and treatment of bleeding in patients without haemophilia (Review)

Copyright $\odot 2012$ The Cochrane Collaboration. Published by John Wiley \& Sons, Ltd. 


\section{Appendix 2. MEDLINE (Ovid) search strategy}

1. FACTOR VIIA/

2. (factor viia OR factor $7 \mathrm{a}$ OR rfviia OR fviia).tw.

3. ((activated adj2 factor seven) OR (activated adj2 factor vii) OR (activated adj3 rfvii) OR (activated adj2 fvii)).tw.

4. (novoseven* OR novo seven* OR eptacog* OR proconvertin OR novo7).tw.

5 (factor seven OR factor vii OR factor 7).ti.

6. or/ $1-5$

7. $\exp$ HEMORRHAGE/

8. (hemorrhag* OR haemorrhag* OR bleed* or bloodloss* or blood loss* OR ICH).tw.

9. $\exp$ HEMOSTASIS/

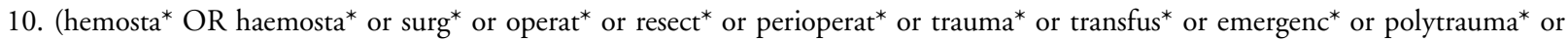
injur* or accident*).tw.

11. or/7-10

12. 6 AND 11

\section{Appendix 3. EMBASE (Ovid) search strategy}

1. BLOOD CLOTTING FACTOR 7A/

2. (factor viia OR factor $7 \mathrm{a}$ OR rfviia OR fviia).mp.

3. ((activated adj3 factor seven) OR (activated adj3 factor vii) OR (activated adj3 rfvii) OR (activated adj3 fvii)).mp.

4. (novoseven* OR novo ADJ seven* OR eptacog* OR proconvertin).mp.

5. or/ $1-4$

6. $\exp$ BLEEDING/

7. (hemorrhag* OR haemorrhag* OR bleed* or bloodloss* or blood near los* OR ICH).mp.

8. HEMOSTASIS/

9. (hemosta* or haemosta*).mp.

10. (surg* or operat* or resect* $^{*}$ or perioperat* or trauma* or transfus* or emergenc* or polytrauma* or injur* or accident*).mp.

11. or/6-10

12. 5 AND 11

\section{Appendix 4. CINAHL (NHS Evidence) search strategy}

1. (factor AND viia OR factor AND 7a OR rfviia OR fviia).ti,ab

2. ((activated adj2 factor seven) OR (activated adj2 factor vii) OR (activated adj3 rfvii) OR (activated adj2 fvii)).ti,ab

3. (novoseven* OR novo AND seven* OR eptacog* OR proconvertin or novo7).ti,ab

4. (factor seven OR factor vii OR factor 7).ti

5. 1 OR 2 OR 3 OR 4

6. exp HEMORRHAGE/

7. (hemorrhag* OR haemorrhag* OR bleed* OR bloodloss* OR blood AND loss* OR ICH).ti,ab

8. exp HEMOSTASIS/

9. (hemosta* OR haemosta* OR surg* OR operat* OR resect* OR perioperat* OR trauma* OR transfus* OR emergenc* OR polytrauma* OR injur* OR accident*).ti,ab

10. 6 OR 7 OR 8 OR 9

11. 5 AND 10 


\section{Appendix 5. OTHER STRATEGIES}

\section{PUBMED}

("activated factor vii" OR “activated factor seven" OR "recombinant factor vii" OR "factor viia” OR rfviia OR fviia OR "activated rfvii” OR “activated fvii”) AND (randomi* OR randomly OR trial OR groups)

LILACS/KoreaMed/IndMed/PakMediNet

factor viia OR activated factor vii OR activated fvii OR activated rfvii OR rfviia OR fviia OR novoseven OR novo seven

TRANSFUSION EVIDENCE LIBRARY/ISRCTN REGISTER/WHO ICTRP Database/EUDRACT (EU Clinical Trials Register)/ClinicalTrials.gov

"factor viia" OR "factor seven" OR rfviia OR fviia OR novoseven OR “activated factor seven" OR "activated factor vii" OR "activated rfvii" OR "activated fvii"

\section{WHAT'S NEW}

Last assessed as up-to-date: 23 March 2011.

\begin{tabular}{l|l|l}
\hline Date & Event & Description \\
\hline 23 March 2011 & New search has been performed & The search for studies was updated to 23 March 2011. \\
\hline
\end{tabular}

\section{H I S T O R Y}

Protocol first published: Issue 4, 2004

Review first published: Issue 2, 2007

\begin{tabular}{l|l|l}
\hline Date & Event & Description \\
\hline 12 September 2011 & $\begin{array}{l}\text { New citation required but conclusions have not } \\
\text { changed }\end{array}$ & $\begin{array}{l}\text { The search was updated to 23 March 2011. Four new } \\
\text { trials have been included in the review. The Results and } \\
\text { Discussion sections have been amended accordingly. } \\
\text { The authors of the review have changed }\end{array}$ \\
\hline 29 July 2009 & New search has been performed & $\begin{array}{l}\text { The search was updated to 25 February 2009. Twelve } \\
\text { new trials have been included in the review. The Re- } \\
\text { sults and Discussion sections have been amended ac- } \\
\text { cordingly. The authors of the review have changed }\end{array}$ \\
\hline 1 May 2008 & Amended & Converted to new review format. \\
\hline
\end{tabular}




\section{CONTRIBUTIONS OFAUTHORS}

CAROLYN DOREE: Searching and protocol development.

SIMON STANWORTH: Protocol development, searching, selection of studies, eligibility and quality assessment, data extraction and content expert.

JANET BIRCHALL: Protocol development, searching, selection of studies, eligibility and quality assessment, data extraction and content expert.

YULIA LIN: Searching, selection of studies, eligibility and quality assessment, data extraction and content expert.

CHRIS HYDE: Methodological quality assessment, data extraction and analysis expert.

EWURABENA SIMPSON: Searching, selection of studies, eligibility and quality assessment and data extraction.

\section{DECLARATIONSOF INTEREST}

Yulia Lin: The author is a study site investigator for a registry on the off-label use of rFVIIa in Canada funded by an unrestricted educational grant from Novo Nordisk but receives no personal financial payments for participation in the registry.

Chris Hyde was an employee of NHS Blood and Transplant when this review was commenced. This arrangement ended in 2009.

The other authors have no declarations of interest.

\section{SOURCES OF SUPPORT}

\section{Internal sources}

- National Blood Service, Research and Development, UK.

- Canadian Blood Services, Canada.

- Department of Clinical Pathology, Sunnybrook Health Sciences Centre, Canada.

\section{External sources}

- No sources of support supplied

\section{INDEX TERMS}

\section{Medical Subject Headings (MeSH)}

*Hemophilia A; Coagulants [*therapeutic use]; Erythrocyte Transfusion [utilization]; Factor VIIa [*therapeutic use]; Hemorrhage $\left[{ }^{*}\right.$ drug therapy; mortality; * prevention \& control]; Randomized Controlled Trials as Topic; Recombinant Proteins [therapeutic use] 


\section{MeSH check words}

Humans 